UNIVERSIDADE DE SÃO PAULO

PROGRAMA DE PÓS-GRADUAÇÃO INTERUNIDADES

EM ESTÉTICA E HISTÓRIA DA ARTE

ISA MÁRCIA BANDEIRA DE BRITO

\title{
Movimento de Arte Contemporânea de Moçambique MUVART: 2004 a 2010
}

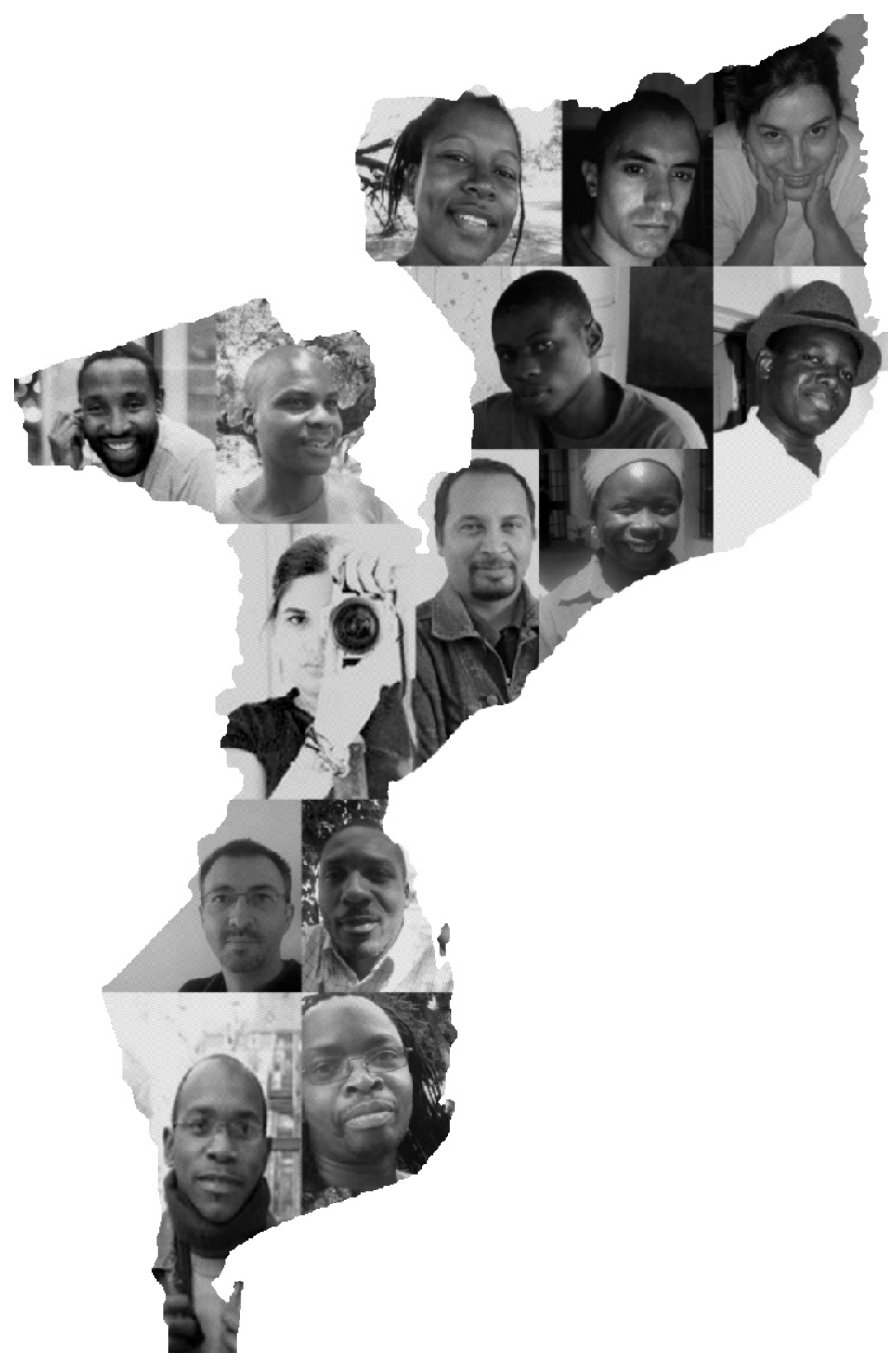




\section{UNIVERSIDADE DE SÃO PAULO PROGRAMA DE PÓS-GRADUAÇÃO INTERUNIDADES \\ EM ESTÉTICA E HISTÓRIA DA ARTE}

ISA MÁRCIA BANDEIRA DE BRITO

Movimento de Arte Contemporânea de Moçambique MUVART: 2004 a 2010 


\section{ISA MÁRCIA BANDEIRA DE BRITO}

\section{Movimento de Arte Contemporânea de Moçambique MUVART: 2004 a 2010}

Dissertação apresentada ao Programa de Pós-Graduação Interunidades em Estética e História da Arte da Universidade de São Paulo para obtenção do título de mestre em Estética e História da Arte, sob orientação da Profa. Dra. Dilma de Melo Silva, na linha de Pesquisa de História e Historiografia da Arte. 


\title{
AUTORIZO A REPRODUÇÃO E DIVULGAÇÃO TOTAL E PARCIAL DESTE TRABALHO, POR QUALQUER MEIO CONVENCIONAL OU ELETRÔNICO, PARA FINS DE ESTUDO E PESQUISA, DESDE QUE CITADA A FONTE.
}

\author{
Catalogação da Publicação \\ Biblioteca Lourival Gomes Machado \\ Museu de Arte Contemporânea da Universidade de São Paulo
}

BRITO, Isa Márcia Bandeira de.

Movimento de Arte Contemporânea de Moçambique: MUVART: 2004 a 2010 / Isa Márcia Bandeira de Brito ; orientadora Dilma de Melo Silva. -- São Paulo, 2012.

236 f.: il.

Dissertação (Mestrado - Programa de Pós-Graduação Interunidades em Estética e História da Arte) -- Universidade de São Paulo, 2012.

1. Arte Contemporânea - Século 21 - Moçambique. 2. Bienais de Arte Século 21 - Moçambique. 3. Artes Plásticas - África. 3. Movimento de Arte Contemporânea de Moçambique (MUVART). I. Silva, Dilma de Melo. II. Título. 
BRITO, Isa Márcia Bandeira de. Movimento de Arte Contemporânea de Moçambique-MUVART: 2004 a 2010. Dissertação apresentada ao Programa de Pós Graduação Interunidades em Estética e História da Arte da Universidade de São Paulo para obtenção do título de Mestre em Estética e História da Arte.

Aprovado em:

Banca Examinadora

$\operatorname{Prof}^{\mathrm{a}} \mathrm{Dr}^{\mathrm{a}}$ Instituição

Julgamento Assinatura

$\operatorname{Prof}^{\mathrm{a}} \mathrm{Dr}^{\mathrm{a}}$ Instituição

Julgamento Assinatura

Prof ${ }^{a} \mathrm{Dr}$ Instituição

Julgamento Assinatura 
Dedico este trabalho aos meus pais, Emília e Alcides, à minha irmã Maíra, à minha querida avó Mila, à minha tia Socorro, à minha filha Luana e ao Julio. 


\section{AGRADECIMENTOS}

À minha orientadora professora Dilma de Melo Silva por todo o seu apoio e dedicação na realização deste trabalho.

A Kabengele Munanga, por reavivar os sonhos e me acolher.

Ao apoio institucional da Universidade de São Paulo e à Coordenação de Aperfeiçoamento de Pessoal de Nível Superior - CAPES.

Aos professores Jane Marques, Alecsandra Matias e Ferdinando Martins por terem aceitado participar da minha banca de qualificação. À professora Carmem Aranha, presença forte e constante em todos os momentos do curso, minha amizade e gratidão. Ao professor Vagner Gonçalves por seu apoio.

À Secretaria do Programa de Pós-Graduação em Estética e História da Arte e à Secretaria da Escola de Comunicação e Artes, da Universidade de São Paulo, Águida, Paulo, Joana, Neusa e a Malu, Regina, Flor, Dario, Tiago e Dodô. Ao Hélio da biblioteca do Museu de Arqueologia e Etnologia - MAE, USP. A Lourdes e Maria Odete do Centro de Estudos Africanos. Ao Alan da biblioteca da Casa das Áfricas.

A Neisa J. de Albuquerque, pela compreensão, contribuição, incentivo e pela revisão ortográfica.

A "minha" equipe de base, meus queridos amigos, Vera de Albuquerque, Elisa Paixão, Cristina Bastos e Edilberto de Oliveira, Bobby e Neusa Growald, pelo apoio irrefutável em todas as áreas, viabilizando e impulsionando esta dissertação.

Aos meus amigos Cristina Caponero, Gabriela, Araceli e Antonio. Também a Ana Luisa, Flávia, Raquel, Marianne, Luís Eusébio, Walter e Luana, pelo imenso carinho demonstrado e por me acompanharem nesta aventura.

Ao Marcelo Mendes pelos incentivos enaltecedores e os muitos cafés.

Ao Pretinho por ter abdicado de seus passeios em favor de tardes e madrugadas passadas junto ao computador.

Aos colegas do curso pela força e companheirismo em todas as horas.

A Yussuf Adam, pelas conversas e discussões sempre pertinentes e principalmente pela infinita paciência em relatar infinitas histórias diante da minha insistente curiosidade.

Aos artistas moçambicanos que tanto me ensinaram com suas obras. E a Maputo, cidade que também me adotou.

Aos colaboradores eventuais e aos não nomeados. Neste desafio, nesta aventura e neste sonho que não se fez sozinho. 
“... não somos eternos e agora que partiste saberei eu transmitir aos teus netos o passado e 0 futuro... saberei?"

Miguel César 


\section{BRITO, ISA MÁRCIA BANDEIRA DE. Movimento de Arte Contemporânea de}

Moçambique - MUVART: 2004 a 2010. 2012. 236 f. Dissertação (Mestrado) Programa de Pós-Graduação Interunidades em Estética e História da Arte da Universidade de São Paulo, São Paulo, 2012.

\section{RESUMO}

O objetivo do presente trabalho é apresentar o Movimento de Arte Contemporânea de Moçambique, MUVART, no período compreendido entre 2004 e 2010, especificamente em sua cidade capital Maputo. Este título foi dado a um grupo formado em sua maioria por jovens artistas moçambicanos e seus fundadores foram Anésia Manjate, Carmem Muianga, Gemuce, Jorge Dias, Ivan Serra, Marcos Muthewuye, Mudaulane, Lourenço Cossa, Vânia Lemos, Quentin Lambert e Xavier M'Beve. Inicialmente, situamos a arte africana e a arte africana contemporânea, tendo em vista a construção de um cenário de apreciação da arte em Moçambique. Os marcos escolhidos foram os séculos XVII e o século XVIII. Com base no Movimento de Arte Contemporânea de Moçambique, MUVART, revela-se o contexto histórico das relações entre a arte tradicional e a arte contemporânea moçambicana. A presença de quatro grupos étnicos fixados no território e de três artistas da geração anterior à analisada na presente pesquisa possibilita a introdução ao tema. Atenção especial é dada a uma atividade desenvolvida pelo grupo, a Bienal ExpoArte Contemporânea, pontuada nas edições de 2004, 2006, 2008 e 2010. Amplia-se o debate com a interlocução de outros artistas convidados na referida exposição que, embora não fazendo parte do grupo original, dialogam com as linguagens contemporâneas. Recupera-se a história individual de cada artista e a história do grupo, sugerindo leituras do cenário da arte contemporânea em Moçambique, suas definições e a projeção na produção estética dos próprios artistas, a compreensão e a apreciação do público especializado. A terceira parte consiste na apresentação dos artistas fundadores do Movimento de Arte Contemporânea de Moçambique, MUVART, com ênfase nos trabalhos inseridos na Bienal Expo-Arte Contemporânea. Torna-se imprescindível atrelar à narrativa momentos históricos de suma importância para Moçambique que irão influenciar a arte moçambicana, considerando que a arte moçambicana começa a ganhar autoria paulatinamente, na concepção moderna de 
obra e autor, uma vez que na arte tradicional esta noção está imersa no seio da comunidade. Todavia, ideologicamente, esta produção autoral é intrinsecamente identificada com os ideais colonizadores, ou seja, deixa de ser exclusivamente uma produção conectada a um grupo específico para refletir os desejos externos a estas comunidades. A implicação destes movimentos irá desaguar na etapa posterior denominada pós-revolução, influenciando, no nosso caso específico, a sociedade moçambicana e consequentemente o percurso da geração seguinte, jovens artistas que já nasceram sob os auspícios da paz e que trazem como lastro esta história a ser contada e recontada.

\section{PALAVRAS-CHAVE}

Coletivo de artistas; Moçambique; Arte Contemporânea Moçambicana; Novas produções. 


\section{ABSTRACT}

BRITO, ISA MÁRCIA BANDEIRA DE. Contemporary Art Movement of Mozambique - MUVART: 2004 to 2010. 2012236 f. Thesis (MA) Graduate Program in Inter Aesthetics and Art History at the University of São Paulo, São Paulo, 2012.

\section{ABSTRACT}

The present work has the purpose to introduce Contemporary Art Movement of Mozambique, MUVART, between the period of 2004 and 2010, specifically in its capital city of Maputo. This title was given to a group mostly formed by young artists of Mozambique and its founders were Anésia Manjate, Carmem Muianga, Gemuce, Jorge Dias, Ivan Serra, Marcos Muthewuye, Mudaulane, Lourenço Cossa, Vânia Lemos, Quentin Lambert e Xavier M'Beve. At first, the African art and the contemporary art are placed, bearing in mind a scenery, constructed of art appreciation in Mozambique. Landmarks of the seventeenth and the eighteenth century were chosen. Based on Contemporary Art Movement, MUVART, the historical context between the traditional art and the Mozambican's contemporary art, is revealed. The presence of four ethnical groups in the territory and three artists from previous generation being analyzed in the present research, made possible the introduction to this subject. Special attention is given to the group's developed activity, the Biennial Contemporary Expo-Art, scored in 2004, 2006, 2008 and 2010 editions. The discussion increases when other invited artists in the mentioned exposition dialogue in a contemporary manner with the original group, although they did not belong to it. Each artist's individual history and the group's history are recovered, suggesting readings of the contemporary art scene in Mozambique, their definitions and the projection of the artists' own aesthetics production, the comprehension and appreciation of the specialized public. The third part consists of the artists' founders of the Contemporary Art Movement of Mozambique's presentation, MUVART, emphasizing the works presented in the Biennial Contemporary Expo-Art. It becomes strictly necessary to tie up historical moments of 
great importance to Mozambique to the narrative that will influence the Mozambican art, considering that it starts to gain gradually its authorship, in the conception of modern work and author, once the idea of traditional art is immersed within the pale of the community. Although, ideologically, this authorial sort of production is intrinsically identified with the colonizers' ideals, meaning, no longer an exclusive production connected to a specific group reflecting external desires to these communities. The implication of these movements will flow into a later stage, called post-revolution, influencing, in our specific case, the Mozambican society and consequently the course of the next generation, young artists who were born under the auspices of peace, bringing as ballast this story to be told and retold.

\section{KEYWORDS}

Collective of artists; Mozambique; Mozambican Contemporary Art; New productions. 


\section{LISTA DE FIGURAS}

Figura $n^{\circ}$

Página

1 Processo de fundição do bronze: "técnica da cera perdida". Yoruba, Nigéria, s/d. Fonte: SALUM, Marta Heloisa Leuba. África: Culturas e Sociedades, Guia temático para professores. Museu de Arqueologia e Etnologia da Universidade de São Paulo, São Paulo, 2008, p.2.

2 Kiluanji Kia Henda. Aloveove "Série versus Carnaval". Acervo. Galeria SOSO. Foto: Vera de Albuquerque.

3 Alberto Tavares. Memórias (From referências I), 2010. Coleção do artista. Foto: Vera de Albuquerque

4 Fachada do Centro Georges Pompidou por ocasião da exposição Magiciens de la Terre, Paris, França, maio-agosto, 1989; curadoria de JeanHubert Martin. Fonte: http://www.buala.org/pt/a-ler/representacao-das-artes-naafrica-desde-o-seculo-passado-contributos-para-um-estudo, último acesso em 7 de setembro/2011.

5 Samora Machel e Joaquim Chissano (AIM), foto.

Fonte: BERGH. Lucia Van den. Porque prevaleceu a paz, Moçambicanos respondem. Editora Annick Osthoff, Parlamentares Europeus com África, AWEPA. Moçambique, s/d, p.14.

6 "As potências coloniais apoiavam príncipes e chefes dispostos a colaborar com seus interesses. Na foto, Lorde Curzon, representante do governo britânico na Índia e o marajá de Petíala." Fonte: apud.CANÊDO.Letícia Bicalho, A Descolonização da Ásia e da África: processo de ocupação colonial:transformações sociais nas colônias: os movimentos de libertação. Atual: São Paulo, Campinas, Universidade Estadual de Campinas, 1985, p.18.

7 Máscara Mapiko Makonde,Tanzania - Moçambique. Máscara Elmo Coleção privada. Fonte: BARGNA, Ivan. Visual Encyclopedia of Art, Arte Africana. Florença: Scala, 2010, p.245.

8 Dança do mapiko na pequena povoação de Impueba.

Fonte: apud. DIAS, Jorge. Os Macondes de Moçambique, Aspectos Históricos e Econômicos. Vol. I Junta de Investigação do Ultramar, Centro de Estudos de Antropologia cultural, Lisboa, 1964, p.33. 
9 Aspectos da Arquitetura Maconde. Fonte: apud. DIAS, Jorge. DIAS, Margot. Os Macondes de Moçambique, Aspectos Históricos e Econômicos. Vol. II Junta de Investigação do Ultramar, Centro de Estudos de Antropologia cultural, Lisboa, 1964, p.17.

10 Aspectos da Arquitetura Macua, "Ettoko", residência macua

Fonte: Apud, MARTÍNEZ, Francisco Lerma. O povo Macua e a sua cultura: Análise dos valores culturais do povo Macua no Ciclo Vital, Mauá, Moçambique 1971-1985. Maputo: Paulinas, $2^{\underline{a}}$ edição, 2008, s/p.

11 Shona, Zimbabwe e África do Sul. Apoio de cabeça, Musée du Quai Branly, Paris Fonte: BARGNA, Ivan. Visual Encyclopedia of Art. Arte Africana. Florença: Scala, 2010, p.252.

12 Escarificações, Aspectos das escarificações MACONDES . Fonte: Apud.

DIAS, Jorge. Os Macondes de Moçambique, Aspectos Históricos e Econômicos. Vol. I Junta de Investigação do Ultramar, Centro de Estudos de Antropologia cultural, Lisboa, 1964, p.61.

13 Aspectos da escultura Maconde relacionada à cultura da escarificação.

Makonde Maternidade, 1880-1900. Kimbell Art Museum, Fort Worth (TX). Fonte: BARGNA, Ivan. Visual Encyclopedia of Art, Arte Africana. Florença: Scala, 2010, p.243.

14 Reinata Sadimba. Fonte: http://ccfmoz.com/, último acesso em ago.2011.

15 MACUA, povos. Exemplo de decoração corporal. Fonte: NEVES, Angelina. Viagens com a cabaça mágica, Nampula, vol.4, Maputo, Moçambique, Ed.Coopimagem, 2002, p.5.

16 Tsongas, Timbila e as suas dez notas. Fonte: JUNOD, Henri. Usos e Costumes dos Bantu, Editor Arquivo Histórico de Moçambique, Maputo, 1996, Tomo II: Vida Mental, p.232.

17 Barragem de Cahora Bassa. Fonte: NEVES, Angelina. Viagens com a cabaça mágica, Tete, vol.5, Maputo, Moçambique, Ed.Coopimagem, 2002, p.16.

18 Malangatana Valente Ngwenya. Foto Maimuna Adam.

20 Desenhos de prisão, 1969. Fonte: http://ma-schamba.blogspot.com/2007/06/desenhos-de-prisao-exposicaode.html, último acesso em nov.2011. 
21 Desenhos de prisão, 1969. Fonte:

http://2.bp.blogspot.com/ PshaZq1PQ9s/RmkZTTQd0nl/AAAAAAAABRk/8olHnexMo NY/s1600-h/Malangatana4.jpg, último acesso em nov.2011

22 Reinata Sadimba,1945. http://ccfmoz.com/, último acesso em ago.2011.

23 Ateliê de Reinata Sadimba. Foto de Vera de Albuquerque.

24 Reinata Sadimba. Mulher Grávida. Fonte: COSTA, Alda. JOSÉ, Benites, Lucas (Org.). Percursos e Olhares, Uma introdução à Arte em Moçambique, Maputo: EPM-CELP, 2008, p.52.

25 Reinata Sadimba. A Colheita. Fonte: Catálogo Artistas de Moçambique, Percursos Recentes, Lisboa, 2007, s/p.

26 Victor Sousa. Fonte: SOUSA, Victor. O Sortilégio Estético de Victor Sousa, Maputo: Alcance EDITORES, 2010, p.19.

27 Ateliê de Victor Sousa. Foto: Vera de Albuquerque.

28 Victor Sousa. O Regresso, 1991. Fonte: SOUSA, Victor. O Sortilégio Estético de Victor Sousa, Maputo: Alcance EDITORES, 2010, p.66.

29 Acolhimento, 2004. Fonte: Catálogo da Expo-Arte Contemporânea, Moçambique, 2004, capa.

30 NORDINE, Amin. O que não é arte e que pode ser considerado como tal. Jornal Zambeze 19.ago.2010, p.31.

Fonte: http://maimunaadam.wordpress.com/press/, último acesso em 09.nov.2010.

31 Catálogos da Expo-Arte Contemporânea, Moçambique.

Bienais de 2004, 2006, 2008.

32 Catálogos da Expo-Arte Contemporânea, Moçambique. Bienal de 2010.

33 Lourenço Pinto. Acervo do artista.

34 Lourenço Pinto. Música de Sonho. (Toque uma ao seu gosto), 2004.

Fonte: catálogo Expo-Arte Contemporânea, Maputo, Moçambique, 2004, p.23.

35 Maimuna Adam. Acervo do artista. 
37 Maimuna Adam, O Lar/Home.

Fonte: Expo-Arte Contemporânea, Maputo, Moçambique, 2010, http://www.youtube.com/watch?v=EOazWCZxUeg

38 Mauro Pinto. Acervo do artista.

39 Mauro Pinto. Portos de Convergência: Angola e a Partida de um Legado Africano, Luanda. 2006. Acervo do artista.

40 Mauro Pinto. Portos de Convergência: Angola e a Partida de um Legado Africano, Luanda. 2006. Acervo do artista.

41 Mauro Pinto. Portos de Convergência: Angola e a Partida de um Legado Africano, Luanda. 2006. Acervo do artista.

42 Mauro Pinto. Portos de Convergência: Angola e a Partida de um Legado Africano, Luanda. 2006. Acervo do artista.

43 Mauro Pinto. Portos de Convergência: Angola e a Partida de um Legado Africano, Luanda. 2006. Acervo do artista.

44 Anésia Manjate. Acervo do artista.

45 Anésia Manjate. Influência da Tradição na Contemporaneidade.

Fonte catálogo Expo-Arte Contemporânea, Maputo, Moçambique, 2004, p.25.

46 Anésia Manjate. Laços.

Fonte: Catálogo Virtual da Artista cedido à autora, 2006.

47 quadro comparativo entre Macondes, Macuas e o trabalho de Anésia Manjate. Fonte: apud. DIAS, Jorge. DIAS, Margot. Os Macondes de Moçambique, Aspectos Históricos e Econômicos. Vol. II Junta de Investigação do Ultramar, Centro de Estudos de Antropologia cultural, Lisboa, 1964, p.17. "Ettoko", Residência macua. Fonte: apud MARTíNEZ, Francisco Lerma. O povo Macua e a sua cultura: Análise dos valores culturais do povo. Macua no Ciclo Vital, Mauá, Moçambique 1971-1985. Maputo: Paulinas, 2ª edição, 2008, s/p. Anésia Manjate Laços Fonte: Catálogo Virtual da Artista cedido a autora, 2006.

48 Experiência. Sapatos de lã, 2008.

Fonte catálogo da Expo-Arte Contemporânea, Maputo, Moçambique, 2008, p.1.

49 Carmen Muianga. Acervo do artista. 
50 Carmen Muianga. Poemas llustrados, 2004.

Fonte catálogo Expo-Arte Contemporânea, Maputo, Moçambique, 2004, p.12.

51 Gemuce. Acervo do artista.

52 Gemuce. 3 Momentos (detalhe), 2004.

Fonte catálogo Expo-Arte Contemporânea, Maputo, Moçambique, 2004, p.20.

53 Gemuce. A Globalização na Faixa de Rodagem, 2006.

Fonte: catálogo Expo-Arte Contemporânea, Maputo, Moçambique, 2006, p.22.

54 Gemuce. Ciclo Vicioso. 2008.

Fonte: catálogo Expo-Arte Contemporânea, Maputo, Moçambique, 2008, capa.

55 Gemuce. Ciclo Vicioso. 2008. Acervo do artista.

56 Gemuce. Ciclo Vicioso. 2008. Acervo do artista.

57 Gemuce. Ciclo Vicioso. 2008. Acervo do artista.

58 Gemuce. Corrida Preconceituosa. 2010. Foto Vera de Albuquerque.

59 Ivan Serra. Acervo do artista.

60 Ivan Serra. O Paradoxo da Publicidade (pormenor, inacabado), 2004. Fonte: catálogo Expo-Arte Contemporânea, Maputo, Moçambique, 2004, p.21.

61 Ivan Serra. A Perda da Inocência. 2000. Fonte: catálogo Expo-Arte Contemporânea, Maputo, Moçambique, 2006, p.35.

62 Ivan Serra. A Perda da Inocência, 2000. Acervo do artista.

63 Jorge Dias. Acervo do artista.

64 Jorge Dias. Sem título, 2004. Fonte catálogo Expo-Arte Contemporânea, Maputo, Moçambique, 2004, p.19.

65 Jorge Dias. Caixas, 2004. Acervo do artista.

66 Jorge Dias. Crise aritmética- Os que aprendem a somar não sabem dividir 2008. Fonte: catálogo Expo-Arte Contemporânea, Maputo, Moçambique, 2008, p.1. 
67 Jorge Dias. Crise aritmética - Os que aprendem a somar não sabem dividir 2008. Acervo do artista.

68 Jorge Dias. Crise aritmética - Os que aprendem a somar não sabem dividir 2008. Acervo do artista

69 Jorge Dias. Crise aritmética - Os que aprendem a somar não sabem dividir 2008. Acervo do artista.

70 Lourenço Eugenio Cossa. Acervo do artista.

71 Marcos Bonifácio "Muthewuye". Acervo do artista.

72 Marcos Muthewuye. Culimando Ideias, 2004. Acervo do artista.

73 Marcos Muthewuye. Culimando Ideias (maquete), 2004.

Fonte: catálogo Expo-Arte Contemporânea, Maputo, Moçambique, 2004, p.26.

74 Marcos Muthewuye. Pensar a água. 2008.

Fonte catálogo Expo-Arte Contemporânea, Maputo, Moçambique, 2008, p.2.

75/76 Marcos Muthewuye. Não é um cemitério. 2010. Acervo do artista.

77 Reportagem RICARDO, Celso. Um cemitério no Museu de Arte. O País, 21 de agosto de 2010, p.22. Fonte: http://maimunaadam.wordpress.com/press/.

78 Marcos Muthewuye. Não é um cemitério. 2010. Acervo do artista.

79 Mondlane. Acervo do artista.

80 Mondlane. Embondeiro Mágico. 2004.

Fonte: catálogo Expo-Arte Contemporânea, Maputo, Moçambique, 2004, p.18.

81 Mondlane. Ndzumba. 2005. Fonte catálogo Expo-Arte Contemporânea, Maputo, Moçambique, 2006, p.39.

82 Quentin Lambert. Acervo do artista.

83 Quentin Lambert. Sem título. 2004. Acervo do artista.

Fonte catálogo Expo-Arte Contemporânea, Maputo, Moçambique, 2004, p.15.

84 Quentin Lambert. Sem título. 2004. Acervo do artista.

85 Quentin Lambert. Sem título. 2004. Acervo do artista. 
87 Quentin Lambert. Sem título. 2004. Acervo do artista.

88 Quentin Lambert. Sem título. 2004. Acervo do artista.

89 Quentin Lambert. Sem título. 2004. Acervo do artista.

90 Quentin Lambert. Sem título. 2004. Acervo do artista.

91 Quentin Lambert. Sem título. 2004. Acervo do artista.

92 Quentin Lambert. Sem título. 2004. Acervo do artista.

93 Vânia Lemos. Acervo do artista.

94 Vânia Lemos. A Ambivalência da Aragem. 2004.

Fonte catálogo Expo-Arte Contemporânea, Maputo, Moçambique, 2004, p.27.

95 Xavier M' Beve. Acervo do artista.

96 Xavier M'Beve. Sem título (Inacabado), 2004.

Fonte catálogo Expo-Arte Contemporânea, Maputo, Moçambique, 2004, p.15. 


\section{LISTA DE MAPAS}

Mapa $\mathrm{n}^{\circ}$

Página

1 Divisão Política da África (atual). Fonte: SOUZA, Marina de Mello. África e Brasil Africano. Ática: São Paulo, 2007, p.17.

2 Localização geográfica da República de Moçambique e de sua capital, Maputo, em relação a outras cidades importantes. Fonte: www.ine.gov.mz.

3 África Colonial (1900 d.C.). Fonte: SALUM, Marta Heloisa Leuba. África: Culturas e Sociedades, Guia temático para professores. Museu de Arqueologia e Etnologia da Universidade de São Paulo, São Paulo, 2008, p.8.

4 Moçambique. Fonte: BERGH. Lucia Van den. Porque prevaleceu a paz,

Moçambicanos respondem. Editora Annick Osthoff, Parlamentares Europeus com África, AWEPA. Moçambique, s/d.

5 Localização Geográfica dos Macuas. Fonte: MARTíNEZ, Francisco Lerma. O povo Macua e a sua cultura: análise dos valores culturais do povo Macua no Ciclo Vital, Mauá, Moçambique 1971-1985. Maputo: Paulinas, 2ª edição, 2008, s/p.

6 Povos Moçambicanos. Fonte: MARTíNEZ, Francisco Lerma. O povo Macua e a sua cultura: análise dos valores culturais do povo Macua no Ciclo Vital, Mauá, Moçambique 1971-1985. Maputo: Paulinas, 2ª edição, 2008, s/p. 


\section{LISTA DE TABELAS}

Tabela $n^{0}$

Página

1 Artistas Fundadores do Movimento de Arte Contemporânea de

Moçambique, MUVART. Fonte: Isa Bandeira.

2 Artistas convidados a participar da Bienal Expo-Arte Contemporânea, organizada pelo Movimento de Arte Contemporânea de Moçambique, MUVART. Fonte: Isa Bandeira.

3 Número de participações como expositores na Bienal Expo-Arte Contemporânea 102 do Movimento de Arte Contemporânea de Moçambique, MUVART. Fonte: Isa Bandeira.

4 Participações de Países e Artistas na Bienal Expo-Arte Contemporânea, do Movimento de Arte Contemporânea de Moçambique, MUVART. Fonte: Isa Bandeira. 


\section{LISTA DE ABREVIATURAS E SIGLAS}

AMF Associação Moçambicana de Fotografia, Maputo.

CDFF Centro de Documentação e Formação Fotográfica, Maputo.

CFM Estação Central dos Caminhos de Ferro.

CCFM Centro Cultural Franco Moçambicano.

ENAV Escola Nacional de Artes Visuais.

ISArC Instituto Superior de Artes e Cultura.

MUSART Museu Nacional de Arte, Maputo.

MUVART Movimento de Arte Contemporânea de Moçambique.

Palops Países africanos de língua oficial portuguesa.

TDM Empresa Telecomunicações de Moçambique. 
1. DA ARTE AFRICANA E DA ARTE AFRICANA CONTEMPORÂNEA

1.1. MOÇAMBIQUE: A EMERGÊNCIA DE UMA NAÇÃO E SUA ENTRADA NO MERCADO DAS ARTES

1.2. ARTE TRADICIONAL MOÇAMBICANA: MACONDES, MACUAS, TSONGAS E NYNGWES

1.3. A CENA ARTÍSTICA: AS RAÍZES ANTES DAS FOLHAS

2. MAPUTO E A ARTE CONTEMPORÂNEA 79

2.1. OS FILHOS DA REVOLUÇÃO: ARTISTAS 89

2.2. MOVIMENTO DE ARTE CONTEMPORÂNEA DE MOÇAMBIQUE, MUVART 93

2.2.1. Novas propostas de produção da arte contemporânea na arte moçambicana 98

2.3. OUTROS INTERLOCUTORES, OUTROS MOVIMENTOS 106

$\begin{array}{ll}\text { 2.3.1. Lourenço Pinto } & 107\end{array}$

$\begin{array}{ll}\text { 2.3.2. Maimuna Adam } & 110\end{array}$

$\begin{array}{ll}\text { 2.3.3. Mauro Pinto } & 115\end{array}$

3. AS FOLHAS DE UMA ÁRVORE SÃO MUITAS, MAS A RAIZ É UMA SÓ 122

3.1. ANÉSIA MANJATE 123

3.2. CARMEN MUIANGA 133

$\begin{array}{ll}\text { 3.3. } & 137 \\ \text { 3.4. } & 13 \text {. }\end{array}$

$\begin{array}{ll}\text { 3.4. IVAN SERRA } & 143\end{array}$

3.5. JORGE DIAS 147

3.6. LOURENÇO EUGENIO COSSA 154

3.7. MARCOS BONIFÁCIO "MUTHEWUYE" 155

3.8. MONDLANE 161

3.9. QUENTIN LAMBERT 164

3.10. VÂNIA LEMOS 168

3.11. XAVIER M'BEVE 171

$\begin{array}{ll}\text { CONCLUSÕES } & 173\end{array}$

$\begin{array}{ll}\text { REFERÊNCIAS } & 178\end{array}$

$\begin{array}{ll}\text { ANEXOS } & 188\end{array}$ 


\section{INTRODUÇÃO}

O grupo Movimento de Arte Contemporânea de Moçambique, MUVART, com sede em Maputo, Moçambique, é o locus deste estudo, nascido do desejo de transformação de onze jovens artistas que juntos formalizaram juridicamente esse movimento.

Sob este pretexto, foi dado um passo a mais em direção ao estudo do continente africano. A possibilidade de ressaltar aspectos originais sobre o tema $\mathrm{e}$ dar voz e visibilidade à arte é o principal objetivo deste trabalho.

No desenrolar da cena artística em Maputo COSTA pergunta:

"Mas onde estamos nós no que se refere ao relacionamento entre a prática
dos artistas de Moçambique e as práticas artísticas internacionais? O
relacionamento entre as práticas artísticas africanas e a arte moderna
ocidental começou há muito tempo, começou por ser imposto porque
associado à colonização, mas não foi apenas num sentido como muitas
vezes se afirma, foi desde o inicio um relacionamento nos dois sentidos..."

A pertinência da análise de COSTA coloca-nos de imediato o confronto entre culturas, inicialmente a cultura moçambicana, portanto local, e a cultura portuguesa, externa. Desta dialética, algo surge e este "algo" ainda está sendo codificado, em relação à arte - as ideias de oposição tratam de forma generalizada as produções artísticas do ocidente versus oriente e a confusão neste sentido se estabelece.

Notoriamente Moçambique nos aparece nesse legado das colônias lusitanas, irmanados pela língua e por uma história comum. Ainda desconhecido por nós, este país de 23.049.621 habitantes (dados do ano de 2011), teve sua capital denominada Lourenço Marques, quando de sua colonização ${ }^{2}$. Sobre este evento ABRAHANSON e NILSSON comentam: "A chegada dos portugueses a llha de Moçambique em 1498 teve, no início, um significado nulo ou muito pequeno para o povo bantu ${ }^{3}$, que

\footnotetext{
Expo-Arte Contemporânea, Catálogo, Maputo, Moçambique, 2004, p.4-5.

2 www.ine.go.mz, último acesso em 26 de setembro de 2011.

3 SERRA, Carlos, História de Moçambique. Vol. I in SERRA, Carlos (dir), Maputo:Departamento de História, Universidade Mondlane, 2000, apud, ..."O processo da expansão dos primeiros falantes Bantu inclui fases ainda pouco conhecidas. Segundo a teoria do lingüista J.H.Greenberg, hoje geralmente aceite, o povoamento Bantu da África Austral teria sido iniciado num processo de expansão, encetado na orla noroeste das grandes florestas congolesas, há cerca de três mil anos, para a bacia do Congo e África Oriental, e de uma migração relativamente rápida para o Sul. A difusão quase simultânea da nova tecnologia de ferro na zona dos Grandes Lagos e África Austral, entre Ca. 500 a.C. e 0, teria acelerado o processo nos três séculos a seguir..." p.12.
} 
vivia no interior da África Oriental..." 4 a realidade foi se alterando gradualmente. A permanência dos portugueses em Lourenço Marques se estende até a independência do país em 1975, quando assume definitivamente a denominação atual, Maputo. Nesse período a maioria dos artistas do MUVART está em sua infância e outros ainda nem nasceram; o aparato ideológico, identificado nessa época, provavelmente é pouco percebido por estas crianças. Entretanto, mesmo optando pelo caminho da arte, estes fatos históricos permeiam o trabalho.

Definido o tema, formulamos o problema da pesquisa, pontuado abaixo:

- Apesar de a Arte Africana estar relacionada à tradição voltada para a escultura e a pintura, de que forma a Arte Contemporânea, permeada de novas linguagens, pode ser vislumbrada na África e em Moçambique, em especial Maputo?

- Quais contribuições podem ser detectadas e quais contribuições são passíveis de serem alcançadas considerando-se a atuação dos jovens artistas moçambicanos para a sociedade desse país?

Para responder a estas perguntas, traçamos objetivos e optamos por uma metodologia que são definidas no início da pesquisa, porém sofreram alterações à medida que nos aproximamos do objeto de estudo e o delimitamos. No primeiro aspecto, estão basicamente divididos em objetivo geral e objetivos específicos como vai discriminado:

\section{Objetivo Geral}

- apresentação da arte africana contemporânea, em Maputo, Moçambique, através da fundação do grupo Movimento de Arte Contemporânea de Moçambique, MUVART, período de 2004 a 2010.

\section{Objetivos Específicos}

- compreensão da importância da produção plástica contemporânea em Maputo para a sociedade moçambicana através do estudo da atuação do grupo de artistas integrantes do Movimento de Arte Contemporânea de Moçambique, MUVART;

\footnotetext{
${ }^{4}$ ABRAHANSON, Hans, NILSSON, Anders. Moçambique em Transição: Um estudo da história de desenvolvimento durante o período 1972-1992. CEGRAF: Maputo, 1994, p.20.
} 
- documentação e registro das origens de fundação do grupo MUVART;

- promoção e incremento de bibliografia sobre o continente e,

- contribuição para novos enfoques sobre o tema e na metodologia de ensino de arte africana, promovendo e incentivando distintas abordagens.

Isto posto, esta pesquisa é fundamentalmente um estudo do estado da arte contemporânea em Moçambique, no período compreendido entre 2004 e 2010, dividida entre trabalho de campo e entrevistas relacionadas com a origem e a atuação do grupo de jovens artistas denominado Movimento de Arte Contemporânea de Moçambique, MUVART. Consequentemente, o material oriundo foi complementado, sistematizado e analisado com o apoio de outras fontes secundárias.

O trabalho de campo comporta a viagem a Moçambique em julho de 2010, quando foram realizadas entrevistas com os artistas do MUVART, visitas às instituições culturais e de ensino (ver Anexo D). Ainda sobre a metodologia, o projeto inicial "utiliza como instrumentos: investigação de caráter observacional e descritivo, entrevistas sem padronização ou não-estruturadas, com o objetivo de levantar a história de vida de cada integrante do grupo de artistas estudado". A adoção de entrevistas abertas junto aos artistas mostrou-se eficaz. Ao dar a palavra ao artista, outros aspectos da obra revelam-se e aproximam o pesquisador do aparato intelectual intrínseco nos processos artísticos e nas linguagens assumidas por cada um.

A pesquisa também adotou o viés qualitativo como define COSTA:

A pesquisa qualitativa é globalizante, holística. Procura captar a situação ou
o fenômeno em toda a sua extensão. Em lugar de identificar a priori
algumas variáveis de interesse, trata de levantar todas as possíveis
variáveis existentes, numa tentativa de enxergar, na sua interação, o
verdadeiro significado da questão sob exame. ${ }^{5}$

Sobre este tema transcrevemos o texto contido no projeto de qualificação:

A opção pelo método qualitativo é intrinsecamente pautado no cunho exploratório, que privilegiará o levantamento bibliográfico, as entrevistas e a análise. Sob este aspecto notamos a ausência no Brasil de uma literatura apropriada ao tema, o que nos levou a adoção deste delineamento exploratório, trazendo referências literárias especificamente de Moçambique

\footnotetext{
${ }^{5}$ COSTA, Sérgio Francisco. Método Científico, os caminhos da investigação. São Paulo: Harbra, 2001, p.39.
} 
e Portugal, configurando-se, portanto material indispensável na compreensão do tema. ${ }^{6}$

Esta classificação proporcionou uma aproximação com o estudo e a definição da bibliografia adotada. Sob este ponto de vista, a bibliografia ainda é incipiente, principalmente no aspecto da arte. Optamos por uma seleção de autores moçambicanos, privilegiando o conhecimento já construído e outros estudos e pesquisas referenciais.

As fontes utilizadas como material básico desta pesquisa são de diferentes tipos:

- constituída de livros e outros tipos de material impresso, quais sejam catálogos, jornais e artigos de revistas;

- outra fonte a ser considerada neste escopo são os websites, páginas de artistas e instituições;

- dvd's - produzidos pelo grupo brasileiro Percursos, e pelos artistas do MUVART.

Em relação ao continente africano foram fundamentais os autores: BALOGUN, CANÊDO, KI-ZERBO, M'BOKOLO, MUNANGA, entre outros citados nas referências.

Especificamente sobre Moçambique: ADAM, CABAÇO, COSSA, COSTA, DIAS, GOMÉZ, JUNOD, MAIA, MARTÍNEZ, ROCHA, SERRA, entre outros citados nas referências.

Sobre o tema da arte moderna e da arte contemporânea, procuramos, sempre que possível, a literaturatura moçambicana, quando da compreensão sobre questões gerais sobre arte tivemos apoio na literatura francesa e na americana.

Salientamos que no Brasil esta ausência de literatura sobre a África também se repete, porém uma fresta se abre, apoiada pela força da lei (Lei 10.639, de 2003 estabelece a inclusão no currículo oficial da rede de ensino a obrigatoriedade da temática "História e Cultura Afro-Brasileira" e a lei 11.645, de 2008 mantém todos os dispositivos anteriores, mas inclui também a obrigatoriedade da temática indígena no currículo) e pela força da conscientização de todos os cidadãos que creem na pluralidade cultural da sociedade.

\footnotetext{
${ }^{6}$ BANDEIRA, Isa. Projeto apresentado à banca de qualificação, 18 de março de 2011.
} 
A abordagem teórica foi se modificando ao longo do período da pesquisa; pretendíamos inicialmente analisar os aspectos econômicos da arte e a inserção dos artistas moçambicanos no cenário local e global. Porém, o aprofundamento da pesquisa e o tempo mostraram a necessidade de registrar primeiro o surgimento do grupo Movimento de Arte Contemporânea de Moçambique, MUVART, como um antecedente à discussão do mercado de arte em si. Era mais urgente entender os agentes do sistema.

Devido a este redirecionamento, passamos a pontuar os artistas (agentes) e sua produção, mas sem aprofundar análises estéticas e/ou teóricas, apenas neste momento resgatando-as e documentado-as. A recuperação desses dados e até mesmo dos artistas fundadores, afastados por diferentes razões, constituiu o material apresentado, inserido nos anexos e no corpo da pesquisa.

Diversos foram os pontos de partida nesta empreitada; os de cunho pessoal, como motivadores, certamente foram os primeiros. Desembarquei em Moçambique em 2004, fazendo parte do grupo Percursos. Éramos quatro artistas brasileiros e mais Priscilla Wood, Marie Brych e Dione Justa que haviam ficado no Brasil, ou seja, totalizávamos sete artistas a integrar a primeira Bienal Expo-Arte Contemporânea daquele país, organizado pelo Movimento de Arte Contemporânea de Moçambique, MUVART. Obtivemos apoio do Ministério da Cultura e da Fundação Palmares.

Ao retornar ao Brasil, continuamos em contato com os artistas moçambicanos. O grupo Percursos expôs nas cidades do Rio de Janeiro e de São Paulo e aqui neste ponto inicia-se minha história com a Universidade de São Paulo, primeiramente como aluna ouvinte, especial, e posteriormente já como aluna regular. Desta feita, encontro no Programa de Pós-Graduação em Estética e História da Arte a professora Dilma de Melo Silva que não só aceita ser minha orientadora como também conhecia Maputo tendo estado lá um ano após nossa ida. A vivência da professora Dilma na África não se resumia nesta passagem em Moçambique: havia residido durante três anos na Guiné Bissau, além de conhecer outros países do continente africano. Evidentemente a sua experiência, não apenas teórica, mas vivencial, foi fundamental no diálogo estabelecido entre pesquisador e orientador.

Em 2010, novamente retorno a Moçambique agora na qualidade de pesquisadora, desta vez juntamente com a professora Dilma, e aproveito a ocasião para entrevistar os artistas e "olhar" a cidade sob outra óptica. Nas caminhadas diárias tenho o privilégio de debater pontos da pesquisa com a professora, o que vai 
consolidando o projeto de estudar a arte contemporânea moçambicana, tomando como ponto de partida o grupo Movimento de Arte Contemporânea de Moçambique, MUVART. Esta opção surge naturalmente uma vez que, tendo formação e prática na área, interessava-me aprofundar o tema, intrigava-me, como artista, o rumo que as artes e os próprios artistas vinham tomando. A oportunidade que a arte me deu de conhecer a África abriu novas perspectivas e horizontes que nunca havia imaginado, tão fortemente as culturas europeia e estadunidense haviam influenciado as duas carreiras que havia abraçado: a Arquitetura e a Pintura. Continuo sendo enriquecida nesta experiência, pois há muito a ser estudado.

A África está na pauta dos debates, em todos os aspectos, do socioeconômico ao artístico. Descobre-se em pleno século XXI que a África é um continente formado por 54 países. Limitamos nosso estudo a apenas um país, Moçambique, e sua capital, Maputo.

Consequentemente, os capítulos foram divididos para dar forma a um percurso da cultura africana e moçambicana, levando a compreensão deste universo de filosofia e valores completamente distintos da filosofia e valores ocidentais. Nesta perspectiva o estudo da história da África mostrou-se rico e complexo.

O primeiro capítulo, "Da Arte Africana e da Arte Africana Contemporânea", aborda as questões de senso comum sobre a arte africana e pontua seu estado atual em outros horizontes de apreciação. É um rito de passagem para a apreciação da arte moçambicana, demonstrando que até mesmo no território existe uma dinâmica na formação étnica, representada aqui pelos Macondes, Macuas, Tsongas e Nyngwes.

Cumprido este ritual, seguimos nos aproximando do Movimento de Arte Contemporânea de Moçambique, MUVART, desta vez com a presença de três artistas representantes de mais um momento histórico fundamental para o País. Malangatana, Reinata Sadiba e Victor Sousa, que nasceram na colônia mas cresceram na aurora da libertação de Moçambique, lutaram a favor dela, muitas vezes usando como armas pincéis e tintas, e outras vezes da melhor forma que podiam.

O segundo capítulo, "Maputo e a Arte Contemporânea", concentra-se na história do grupo e mais especificamente na identificação do cenário e das discussões em torno do que é a própria arte e sobre que matriz a comunidade moçambicana está empregando nas linguagens artísticas. Conta, ao mesmo tempo, 
a luta do segmento artístico e da sociedade moçambicana na construção e afirmação de sua identidade nacional. O que por todo o continente africano foi uma realidade, o que podemos ver pelas consequentes independências que se sucederam na África.

O grupo MUVART convida outros artistas moçambicanos a integrar a Bienal Expo-Arte Contemporânea. Apresentaremos: Lourenço Pinto, Maimuna Adam e Mauro Pinto, abarcando outras mídias e linguagens artísticas. A proposta da inserção destes trabalhos é demonstrar que a prática artística é um processo contínuo em que diversas gerações e influências convivem embora em tempos históricos distintos.

O terceiro capítulo, "As folhas de uma árvore são muitas, mas a raiz é uma só", dedica-se a apresentar os artistas fundadores do Movimento de Arte Contemporânea de Moçambique, MUVART, e os trabalhos expostos na Bienal Expo-Arte Contemporânea nas edições de 2004, 2006, 2008 e na última, de 2010, mostra principal do grupo. Os fundadores são apresentados neste contexto como expositores e observamos a existência de uma ponte entre a tradição e a contemporaneidade em suas obras.

Para finalizar, a intersecção entre os mais distintos saberes, antropologia, história, sociologia, economia, pedagogia, arquitetura, entre outros, transmutaram-se em uma experiência multidisciplinar, assim como a revisão de estudos já consagrados da história da arte. Como Gombrich e Argan nos mostram que o conhecimento também é dinâmico e propiciona mudanças profundas. 
DA ARTE AFRICANA E DA ARTE AFRICANA CONTEMPORÂNEA 


\section{DA ARTE AFRICANA E DA ARTE AFRICANA CONTEMPORÂNEA}

Antes de introduzir o tema da arte no continente africano, algumas ponderações são necessárias em relação à visão sobre a África.

A lacuna de informações, investigações e conhecimento sobre o tema da Arte Africana no Século XXI no Brasil é evidente, merecendo um estudo mais aprofundado. Os estudos existentes concentram-se na produção dos séculos anteriores. Na área da História e da Antropologia a situação é um pouco distinta como observa KI-ZERBO:

Não é preciso ser historiador para observar que não se passa mês nenhum no mundo sem que sejam publicados vários livros sobre a história da África. A valorização do passado deste continente é um sinal dos tempos. (...) De resto, a África, saída da sombra para passar ao primeiro plano na cena internacional, tornou-se um tema interessante (...). Outro elemento objectivo desta valorização é constituído pelas descobertas recentes que a história e a arqueologia acumularam, pondo a descoberto civilizações inteiras (Ife, Nok, vale do Rift etc.) e o papel motor desempenhado em muitas situações pela África na história universal. ${ }^{7}$

Mas a África descrita na citação acima está configurada de forma mais generalizada, ampliando o debate. MUNANGA endossa:

\footnotetext{
Estamos todos acostumados a escutar e a ler, até nos textos eruditos, os conceitos relacionados à África no singular. Cultura africana, civilização africana, africanidade no seu emprego singular remetem, sem duvida a uma certa unidade, a uma África única. Mas diante da extraordinária diversidade e complexidade cultural africana, como é possível conceber uma certa unidade ${ }^{8}$
}

Apesar de pontos de vista e abordagens de origens distintas, os autores $\mathrm{KI}$ ZERBO e MUNANGA contestam a visão estática difundida sobre o continente africano. A relação e a importância dadas à produção artística africana podem ser vistas desde os gabinetes de curiosidades que se formaram a partir das diversas expedições ou/e missões a esse Continente, como atestam outros pesquisadores, nos primórdios dos estudos sobre arte africana.

\footnotetext{
${ }^{7}$ KI-ZERBO, Joseph. História da África Negra, vol. I. Portugal: Publicações Europa-América Ltda, 2009, p.9-10.

${ }^{8}$ MUNANGA, Kabenguele. "O que é Africanidade". In: Vozes da África. Biblioteca entre livros, São Paulo: Seguimento Ediouro, ed.6, p. 8, (não há referência ao ano da edição).
} 
Ao delinear a arte africana considerada "tradicional" 9 , existente primeiramente no continente africano e posteriormente levada para o ocidente, veremos como o passado se expressa no presente, preservando e reinterpretando símbolos e signos.

Os gabinetes de curiosidades foram a princípio os primeiros divulgadores da produção deste continente fora dele, como dito anteriormente. Novamente KIZERBO, pesquisador da história da África, salienta sobre a compreensão dessas origens:

... A arte exprimiu, em primeiro lugar, a admiração perante a vida animal que fervilhava em volta do abrigo pré-histórico. O jovem coberto de uma pele de corça e que acabava de participar no esquartejamento de um elefante abatido pela primeira vez pelo bando familiar revivia naturalmente durante os momentos de lazer essas horas exaltantes da caça e, maquinalmente, projetava-as nas paredes da gruta... ${ }^{10}$

Embora se tenha esta compreensão, persiste a representação destas visualidades pelo viés redutor do utilitário e religioso; ao contrário, consideramos o resultado desta ação como a representação da ligação dos homens com o cosmos, e comum a todos os processos de formação de culturas. Há uma inadequação da aplicação do termo religioso à expressão artística de todas as sociedades; mais adequado seria o entendimento de sua filosofia, porque a religião já é em si a institucionalização de um aspecto estrutural dos grupos sociais. Neste sentido, os objetos aí produzidos e detentores de uma ordem estética comprovam que na sua origem o ideal de criar a beleza é notório em toda a história da civilização humana.

Comumente atrelado à ideia de arte africana está o conceito de homogeneidade de sua cultura. Constatamos a sofisticação e a variedade na construção do código estético africano, inclusive sua heterogeneidade. Tecnicamente a África é vanguarda na manipulação de materiais que só tardiamente o Ocidente veio vislumbrar. KI-ZERBO, ao relatar o estado de conservação das pinturas pré-históricas, descreve:

As tintas de todas estas pinturas conservam uma frescura notável. Isto prova que foram preparadas com pigmentos muito resistentes. A variedade é bastante reduzida, pois se limita, em geral, ao vermelho, ao castanho, ao amarelo (que são ocres tirados dos óxidos de ferro), ao branco (tirado do

\footnotetext{
${ }^{9}$ Consideramos este termo "tradicional" referente a produção ou manifestação artística antes da influência do colonialismo e do capitalismo entre os distintos grupos africanos.

${ }^{10}$ ZERBO-KI, Joseph. Op.cit., 2009, p. 70-71.
} 
excremento de pássaros ou do caulino) e ao preto (proveniente do carvão vegetal, de ossos calcinados e esmagados, de fumos ou de gorduras queimadas). ${ }^{11}$

Retirada de seu condão original, o Ocidente "cria" uma África e uma arte que continua sobrevivendo no nosso século no imaginário popular. Postos em dispersão, estes objetos e esta cultura corporificam a necessidade de uma catalogação e é este o papel das ciências, principalmente, no nascedouro das ciências modernas tais como a etnografia, a etnologia e a antropologia. A partir daí, estes objetos, ou esta cultura, antes detentores de outros sentidos, são promovidos unicamente a contemplação estética e institucionalizados como arte. O Ocidente declara: é arte! Consequentemente os maiores acervos de arte africana ficam nos museus da Europa Ocidental; o que os países fora da sociedade africana sabem sobre a arte africana está relacionado principalmente às expedições e/ou missões e aos relatos de viagem, e a maioria desse conhecimento remete ao tempo pré-colonial e colonial, como é o caso da documentação produzida pela Junta de Investigação do Ultramar de Portugal.

No âmbito das investigações, a utilização de processos sofisticados e o manuseio de metais nobres já eram usuais no continente (Fig. 1); nessas práticas, nota-se o processo de aplicação da cera perdida na fundição do bronze, peça integrante do acervo do Museu de Arqueologia e Etnologia da Universidade de São Paulo, MAE-USP. Denota-se aqui que os africanos possuíam saberes muito antes que o Ocidente os avalizassem.

Em relação à metalurgia do ferro e à cultura material, M'BOKOLO cita:

Neste vasto espaço, os utensílios de ferro substituiriam muito rapidamente os utensílios de pedra talhada. Não se sabe a partir de que época o ferro começou a ser empregado no fabrico de objetos utilitários - enxadas, machados, pontas de flechas ou de lança, lâminas de faca e diversos outros utensílios e armas - e a outros metais, principalmente o cobre e o ouro. ${ }^{12}$

Além dos utensílios de ferro citados pelo autor, pode-se incluir também nesta observação a confecção de esculturas, em bronze, em ferro e ouro. É mais

\footnotetext{
${ }^{11}$ ZERBO-KI, Joseph. Op. cit., 2009, p. 73-74.

12 M'BOKOLO, Elikia. Africa Negra, História e Civilizações, Tomo I (até o século XVIII). Salvador, EDUFBA; São Paulo: Casa das Áfricas, 2009, p. 71.
} 
comumente encontrada em madeira e em terracota, além das peças de cerâmica que compõem a vida diária do africano.

Isto posto, em última análise o "primitivo", ou seja, o não-civilizado apontado pelo Ocidente, refere-se a praticamente todos os povos colonizados, incluindo-se os africanos, aborígenes e os ameríndios e consequentemente toda a sua expressão no âmbito sociocultural e econômico.

Estes conceitos iniciais sobre a arte africana traduzem primeiramente a relação e a visão etnocêntrica do Ocidente em referência a esta matriz. Ultrapassada esta barreira inicial e questionados estes conceitos, o segundo objetivo é apresentar então a arte contemporânea identificada com este continente, atualizando o olhar para a África.

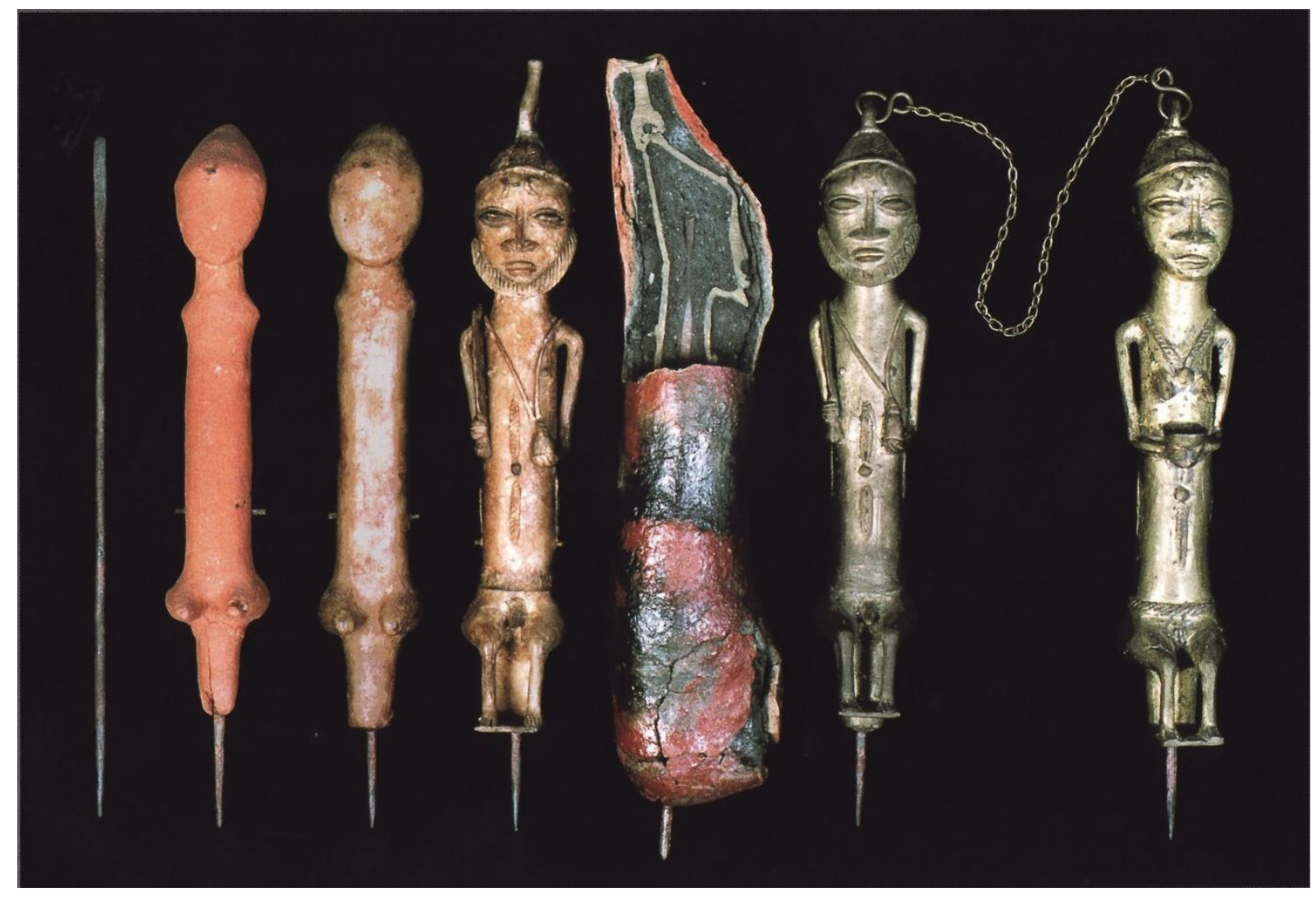

Figura 1

Processo de fundição do bronze: "técnica da cera perdida" Yoruba, Nigéria

Ferro, argila, cera, bronze $\mathrm{s} / \mathrm{d}$ 
Para nomear a Arte Africana Contemporânea, utiliza-se como principal fonte a pesquisa de $\operatorname{DIAS}^{13}$. Foram selecionados quatro eventos relacionados a este período artístico que compreende os séculos XX e XXI, resumidamente, a Bienal de Arte Africana de Dakar, DAK'ART(1990), a Bienal de Joanesburgo (1995), Magiciens de la Terre (1989) (ver figura 4), e Africa Remix.Contemporary Art of a Continent (2004), estas duas últimas realizadas fora do continente africano.

A exposição denominada Bienal de Arte Africana de Dakar, DAK'ART, tem tido uma continuidade admirável; tendo seu marco inicial em 1989, segundo o site do evento, esta primeira edição foi dedicada às letras e somente em 1990 à arte contemporânea. DIAS argumenta que já fazia parte da política cultural do Presidente Léopold Senghor ${ }^{14}$ o empreendimento nesta área. Com inscrições abertas para a sua edição de 2012, os organizadores do evento fazem uma retrospectiva:

La Biennale d'Art Africain Contemporain de Dakar est aujourd'hui l'unique
manifestation d'envergure sur le continent. En 9 éditions et 20 ans
d'existence, elle ne cesse de faire évoluer ses préoccupations relatives à la
production artistique africaine contemporaine. Cette édition de la Biennale
est celle d'une transition: la Biennale des arts visuels aura 20 ans en 2012 .
Cette rétrospective propose un regard sur le chemin parcouru. ${ }^{15}$

Além de sua longevidade, caracteriza-se pela candidatura restrita aos artistas africanos ou artistas africanos em diáspora e é reconhecida no cenário internacional.

A Bienal de Joanesburgo, próxima exposição a ser comentada, tem sua primeira edição em 1995, dirigida por Christopher Till, com direção artística de Lorna Ferguson. Novamente DIAS conduz a análise:

A Bienal de Arte de Joanesburgo surge com o fim do regime de apartheid, tendo-se apresentado como um esforço para restaurar a relação da arte sulafricana e dos seus artistas com o mundo da arte ocidental/internacional.

A África do Sul é, dos países africanos, o que há mais tempo apresenta e trabalha a arte contemporânea, tendo a sua produção artística um

\footnotetext{
${ }^{13}$ DIAS, Inês de Almeida e Costa, Mestre em Estudos Curatoriais, Universidade de Lisboa, Faculdade de Belas Artes, Portugal, 2006.

${ }^{14}$ Léopold Sédar Senghor (1906-2001) foi o primeiro Presidente do Senegal, entre 1960 a 1980.

15 "A Bienal de Arte Africana Contemporânea de Dacar é hoje em dia a única manifestação de envergadura no continente. Em 9 edições e 20 anos de existência ela não para de fazer evoluir suas preocupações relativas à produção artística africana contemporânea. Esta edição da Bienal é uma transição: a Bienal de artes visuais fará 20 anos em 2012. Esta restropectiva propõe um olhar sobre o caminho percorrido." Tradução livre da autora, http://www.dakart.org/2010/spip.php?rubrique5, último acesso em 20/09/2011.
} 
reconhecimento ocidental, e existindo circuitos de arte definidos, galerias, museus, escolas de arte, críticos etc. ${ }^{16}$

Encontram-se também disponíveis na internet mais informações sobre esta mostra que atestam o seu fim, tendo a sua última edição sido realizada em 1997 com a direção artística de Okwui Enwezor.

No site encontra-se o seguinte depoimento:

After the years of isolation as a consequence of the apartheid system, the Biennale of Johannesburg was meant to restore the dialog between South Africa and the international art scene. The 1st Edition took place in 1995, a year after the first free elections.

In spite of the great international interest, the 2nd Edition in 1997 was closed a month ahead of the planned schedule. "Financial problems of the city of Johannesburg", was announced as the official reason. Since then, no further Johannesburg Biennale took place. The organizing institution, the Africus Institute for Contemporary Art (AICA), was dissolved in the meantime. ${ }^{17}$

A próxima amostra a ser comentada brevemente ocorre no ano de 1989, no Centro Georges Pompidou, em Paris, intitulada Magiciens de la Terre (fig. 3) sob a responsabilidade de Jean-Hubert Martin, mostra que se desdobrou também no Parc la Villette, ainda na capital parisiense.

DIAS destaca o objetivo desta exposição:

A exposição teve por base a ideia de arte enquanto global, passível de ser produzida em qualquer cultura, mesmo que não-ocidental, e passível de ser apresentada numa das mais importantes instituições de arte da Europa, dessa forma sendo legitimada, ao olhar ocidental, enquanto objecto de arte. Ganhava mais uma vez corpo a invasão unilateral das regras ocidentais, a exaltação da sua autoridade e poder para avaliar a produção artística das sociedades não-coloniais. ${ }^{18}$

DIAS segue adiante na análise desta mostra, mas resumidamente alguns critérios foram definidos pela curadoria do evento e descritos pela autora tais como:

${ }^{16}$ DIAS, Inês de Almeida e Costa, DIAS.POR.AQUI, Projecto para uma exposição, vol.II, Tese de Mestrado em Estudos Curatoriais, Universidade de Lisboa, Faculdade de Belas Artes, Portugal, 2006, p.37.

17 "Após os anos de isolamento como consequência do sistema de separação racial (Apartheid), a Bienal de Joanesburgo pretendia restaurar o diálogo entre a África do Sul e a cena de arte internacional. A primeira Edição teve lugar em 1995, um ano depois das primeiras eleições livres. Não obstante o grande interesse internacional, a segunda edição em 1997 fechou um mês antes do planejado. "Problemas financeiros da cidade de Joanesburgo", foi a razão oficialmente apresentada. Desde então, nenhuma outra Bienal de Joanesburgo foi organizada. A instituição organizadora, The Africus Institute for Contemporary Art (AICA), Instituto Africano para a Arte Contemporânea foi, entretanto, dissolvido. Tradução livre da autora, http://www.universes-in-universe.de/car/africus/english.htm, último acesso em 20/09/2011.

${ }^{18}$ DIAS, Inês de Almeida e Costa, op.cit., p.7-8. 
- Participação de Artistas ocidentais e não-ocidentais

- $\quad$ Artistas contemporâneos vivos

- Peças identificadas pelo autor e datadas

- $\quad$ Artistas autodidatas

Por último, em 2004, a exposição Africa Remix. Contemporary Art of a Continent, tem como diretor artístico e comissário-geral Simon Njami. Apresentada pelas instituições Museum Kunst Palast, Düsseldorf; Hayward Gallery, Londres, e Centre Georges Pompidou, Paris, e o Mori Art Museum, Tokyo (instituições que coproduziram a exposição), segundo DIAS é descrita como:

... tem como objectivo dar conta da produção artística contemporânea africana dos últimos dez anos, abrangendo os artistas vivos que residem em África e parte da diáspora africana (só os casos que viveram ou se formaram no país africano de origem). Foram apresentados 88 artistas de 25 países, em três núcleos temáticos- Body \& Soul, History, City \& Land. ${ }^{19}$

Um ano depois, em 2005, o Centro Georges Pompidou organizou uma segunda grande mostra do África Remix, avaliada abaixo;

Njami nos chamou a atenção para uma realidade que existe no mundo da
arte como um todo: a dificuldade que os artistas encontram para falar por
eles mesmos, sem necessariamente a intermediação interpretativa dos
considerados "especialistas". A partir daí nos colocou o problema que os
africanos enfrentam no universo da arte contemporânea: Quem seriam
eles? Artistas? Africanos? Artistas africanos?" 20

Ampliando o debate, no cenário artístico global, a África começa a despontar com a inserção de outros países como a Angola, através dos artistas Délio Jasse, Ihosvanny, Kiluanji Kia Henda, (ver figura 2) Nástio Mosquito e Yonamine, estes dois últimos presentes na $29^{\underline{a}}$ Bienal de São Paulo, 2010. Também podemos citar: Cabo Verde, com Gaio e Alberto Tavares (ver figura 3); Guiné Bissau, com Flaviano Mindela e Nú Barreto; São Tomé e Príncipe, com Eduardo Malé e Timor Leste, com Maria Madeira, Etson Arintes e Zito Soares da Silva, isso apenas no contexto das ex-colônias portuguesas. Benin também se tem feito representar, com os artistas Georges Adéagbo, Dominique Zinkpè, Gérard Quenum e Tchif dentre outros. No geral, o traço comum desses artistas é a manipulação de novos suportes, fotografia, vídeo, instalações e até mesmo a pintura e a escultura.

${ }^{19}$ DIAS, Inês de Almeida e Costa, op.cit., p. 26-27.

${ }^{20}$ http://www.casadasafricas.org.br/img/upload/609301.pdf, último acesso em 03 de julho de 2011. 


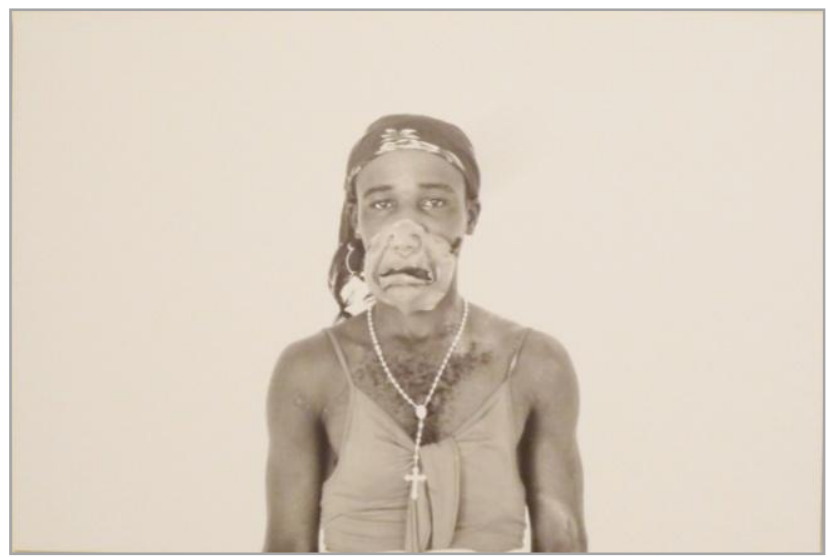

Figura 2

Kiluanji Kia Henda

Angola

Aloveove "Série versus Carnaval", detalhe Impressão digital s/ papel e alumínio $67 \times 100 \mathrm{~cm}$,

Acervo Galeria SOSO,

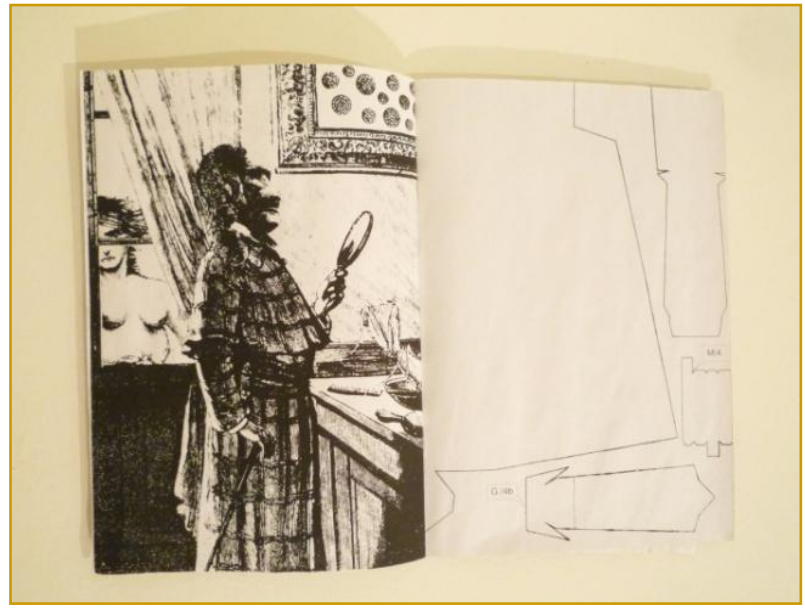

Figura. 3

Alberto Tavares

Cabo Verde

Memórias (From referências I)

Técnica mista colagem

$30 \times 40 \mathrm{~cm}$,

2010

Coleção do artista,

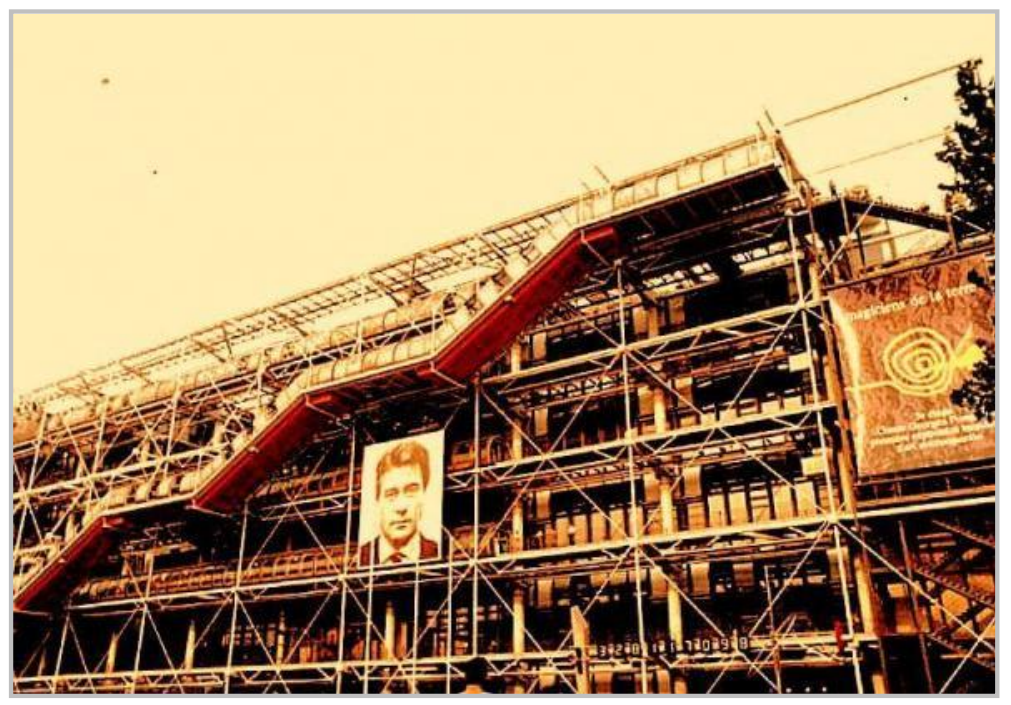

Figura 4

Fachada do Centro Georges

Pompidou por ocasião da

exposição Magiciens de la Terre,

Paris, França, maio-agosto, 1989;

curadoria de Jean-Hubert Martin. 
As exposições internacionais ocorridas nessas instituições tratam da Arte Africana Contemporânea, tanto dentro do continente africano como fora dele. Porém, em relação à Arte Moçambicana Contemporânea, esta ainda é pouco conhecida. As colocações de NJAMI sobre "a dificuldade que os artistas encontram para falar por eles mesmos" vão ao encontro dos questionamentos dos jovens artistas moçambicanos.

Há também uma expectativa por parte do mercado de arte internacional por artistas que representem a escola artística da qual os centros europeus demandam, ou seja mais identificada à escola européia, o que MUNANGA denomina como "ideais da Missão Civilizadora".

Segundo o autor:

Por muito tempo, a arte negro-africana ficou excluída da história universal
da arte tal como foi ensinada na Europa. Considerada primitiva como os
povos que a produziram, pensava-se, de acordo com o esquema
evolucionista do século XIX, que esta arte ainda se encontrava na fase
infantil representada pela forma figurativa e que podia evoluir até chegar um
dia à fase adulta representada por uma arte intelectual geométrica e
abstrata, fase em que se encontrava a Europa "civilizada". Esta visão era
sem dúvida apoiada nos preconceitos da época, na ignorância da
complexidade e sofisticação da arte negro-africana, e também nos ideais da
Missão Civilizadora. ${ }^{21}$

Então, como aponta MUNANGA, a distorção na história e na historiografia é latente no que se refere à identidade africana inserida em uma perspectiva eurocêntrica, situação esta deflagrada em distintas áreas do conhecimento, tais como a Antropologia, a Etnografia, a Filosofia. Na própria História da Arte, $\mathrm{GOMBRICH}^{22}$ situa os povos africanos como primitivos, reproduzindo desta forma o discurso hegemônico que perdura até hoje sobre a arte e a cultura africana no sentido de ausência de saberes, e publica exemplo de máscara africana como simplesmente um objeto, sem levar em consideração seu uso de máscara em sua origem, no seio da sua comunidade, ou seja, adota-se o mesmo procedimento dos Etnógrafos e Antropólogos do século XIX. ARGAN ${ }^{23}$, outro importante pesquisador na área, em seu estudo sobre a Arte Moderna, ao delinear o Cubismo, utiliza um

\footnotetext{
${ }^{21}$ MUNANGA, Kabengele. "A dimensão estética da arte negro-africana tradicional". In: AJZENBERG, Elza. (Org.). Arteconhecimento. São Paulo: MAC-USP, 2004, p.29.

${ }^{22}$ GOMBRICH.E.H. A História da Arte. Rio de Janeiro: LTC, 2008.

${ }^{23}$ ARGAN, Giulio Carlo. Arte Moderna. São Paulo: Companhia das Letras, 1992.
} 
exemplo de máscara africana produzida pelo pintor e escultor espanhol Pablo Gargallo. Acredita-se respectivamente nestas duas obras capitais que estes dois autores minimizam o tema. Atesta-se o etnocentrismo, no qual a tendência é de uma visão unilateral tanto da cultura material como da imaterial ${ }^{24}$.

Mediante esta situação, ainda se indaga no senso comum o porquê de estudar a Arte Africana; é importante conferir e adequar o lugar do continente africano no âmbito da História e das demais áreas do saber, como o das artes visuais, no presente e no futuro. Esse aspecto já suporia uma justificativa plausível.

Tratando-se de História da Arte, são várias as hipóteses e caminhos a seguir pelos pesquisadores, desde análises com viés psicossocial, ou na revisão de estudos já consagrados nas áreas da História da Arte, como se nota em GOMBRICH e ARGAN, ou através de argumentos fornecidos pela Sociologia, Antropologia, entre outros estudos. Assim, durante muito tempo, sob a perspectiva histórica, a Arte Africana dispõe de uma produção "primitiva" e congelada. Torna-se relevante uma nova visão dedicada à Arte Contemporânea Africana e o recorte sobre o universo da Arte Contemporânea Moçambicana.

Nesse sentido, a argumentação de HALL na qual "Cada conquista subjugou povos conquistados e suas culturas, costumes, línguas e tradições, e tentou impor uma hegemonia cultural mais unificada" ${ }^{25}$ torna-se uma política por todo o território. Durante o processo histórico essas tentativas nem sempre lograram o êxito esperado. As sociedades têm provado serem dinâmicas e heterogêneas. $E$ os artistas e a arte, geralmente, atuam como agentes inovadores de ideias e comportamentos em todas as sociedades.

Em análise provocadora sobre as diversas faces do terrorismo, da globalização e sobre o próprio modus operandi do Ocidente, BAUDRILLARD também comenta:

Qualquer cultura que se universalize perde a sua singularidade e morre. Foi assim com todas as culturas que destruímos, incorporando-as pela força,

${ }^{24}$ O Instituto do Patrimônio Histórico e Artístico Nacional (IPHAN) no Brasil divide o Patrimônio Cultural em dois grupos: imaterial e material. O imaterial é aquele em que as práticas, representações, expressões, conhecimentos e técnicas, instrumentos, objetos, artefatos e lugares são reconhecidos por comunidades como parte integrante de seu patrimônio cultural. Disponível em: http://www.brasil.gov.br/sobre/cultura/patrimonio/patrimonio-material-e-imaterial último acesso em 26 de setembro de 2011.

${ }^{25}$ HALL, Stuart. A identidade cultural na pós-modernidade. $6^{\underline{a}}$ ed. Rio de Janeiro:DP\&A, 2001, p.60. 
mas também é assim com a nossa, em sua pretensão ao universal. A diferença é que as outras culturas morreram de sua singularidade, o que é uma bela morte, enquanto que nós morreremos da perda de toda singularidade, da exterminação de todos os nossos valores, o que é uma morte horrível. ${ }^{26}$

No âmbito jurídico, a identidade, e consequentemente o reconhecimento de uma cidadania, podem ganhar também contornos extremamente imprecisos, segundo observam SÁ, BRITO:

Não se restringem a um vínculo territorial pelo nascimento ou pela habitação. O Dicionário Aurélio Buarque de Holanda a define como "qualidade ou estado do cidadão"; é aquele que habita a cidade, o indivíduo no gozo dos direitos civis (art. $2^{\circ}$ do Código Civil), sociais e políticos (art.14 da CF) de um Estado.

(...) É tudo e pode não ser nada, pois suas fronteiras vão ser definidas pela forma como o Estado e a coletividade se organizam. ${ }^{27}$

Portanto, o próprio conceito de identidade se encontra em aberto na contemporaneidade, onde vários paradigmas estão a ser questionados. Ao longo do tempo a arte provou ser como expressão humana também dinâmica e questionadora.

Considerando a arte desenvolvida em Moçambique, verifica-se mais uma vez que o acesso ao conhecimento dos elementos artísticos contemporâneos daquele país trará a ideia de uma África plural, hipótese defendida na construção desta pesquisa. É importante frisar que a organização de bienais de arte na própria África, em Dacar $^{28}$, Joanesburgo ${ }^{29}$, primeira edição em 1995, Cairo ${ }^{30}$, Festival de Fotografia Africana de Bamako ${ }^{31}$, Trienal de $L$ uanda $^{32}$ e a Bienal de Maputo ${ }^{33}$, primeira edição 2004, contribuem para a visibilidade e o intercâmbio artístico.

${ }^{26}$ BAUDRILLARD. Jean. Power Inferno. Porto Alegre:Sulina, 2003, p.52.

${ }^{27}$ SÁ, Elida. BRITO, Isa. "O Planejamento como instrumento da construção da cidadania." São Paulo: Revista de Direito Ambiental, oo7, jul/set, 1997, p.39.

28 Bienal Africana de Dakar, primeira edição em 1990.

${ }^{29}$ Bienal de Joanesburgo, primeira edição em 1995.

${ }^{30}$ Bienal do Cairo, última edição em 2011.

31 "Les Rencontres Africaines de la Photographie ont été créées en 1994 à Bamako (Mali), à l'initiative de l'association Afrique en Créations, avec le soutien du gouvernement malien. Cette première édition fut pilotée par deux photographes français, Françoise Huguier et Bernard Descamps, fondateurs de cette initiative. Les œuvres d'une cinquantaine de photographes venus d'une quinzaine de pays africains ont permis de produire une vingtaine d'expositions et de souligner la richesse d'un secteur encore méconnu de la création africaine dans ses dimensions artistiques, économiques, historiques et documentaires." "Os encontros africanos de fotografia foram criados em 1994 em Bamaco (Mali), por iniciativa da Associação África em Criação, com o suporte do governo maliense. Esta primeira edição foi conduzida por dois fotógrafos franceses, François 
A dicotomia entre o exótico e o primitivo versus o cientifico e o civilizado que ainda persiste ideologicamente e exposta até o momento, será deixada de lado em prol da apresentação de Moçambique, tendo como capital a cidade de Maputo. Palco de inúmeras disputas externas e internas, reconstruindo sua história, sua economia e sua cultura.

Neste sentido, a compreensão do universo tradicional versus 0 contemporâneo é acima de tudo a compreensão das mudanças de paradigmas das sociedades, de valores e na recodificação das culturas como já dito.

Trata-se da arte africana, mais especificamente moçambicana e de um grupo de artistas que têm pouco espaço social para sua apreciação e divulgação, visando a desvelar seu processo de criação atual, uma vez que a arte africana, não importa em qual parte geográfica do continente que estejamos estudando, passa por modificações e influências como qualquer manifestação artística, independentemente de suas origens.

No mapa 1, notam-se os 54 países integrantes do continente africano, carregado de um passado de grande reinos e impérios, colônias e o seu mais recente perfil e distribuição geográfica e política. É neste território que continuam a resistir os povos africanos, em dinâmica constante, produzindo culturas que ainda comovem e deixam o Ocidente surpreso.

Huguier e Bernard Descamps, fundadores desta iniciativa. As obras de uma ciquentena de fotógrafos vindos de uma quinzena de países africanos permitiram produzir uma vintena de exposições e sublinhar a riqueza de um setor então pouco conhecido da criação africana nas suas dimensões artísticas, econômicas, históricas e documentais." Tradução livre da autora,

http://rencontres-bamako.com/francais/les-rencontres/historique/?lang=fr, último acesso em $12 / 09 / 2011$.

32 Última edição 2011.

${ }^{33}$ Primeira edição 2004, 2006, 2008, 2010. 
Mapa 1: Divisão Política da África (atual)

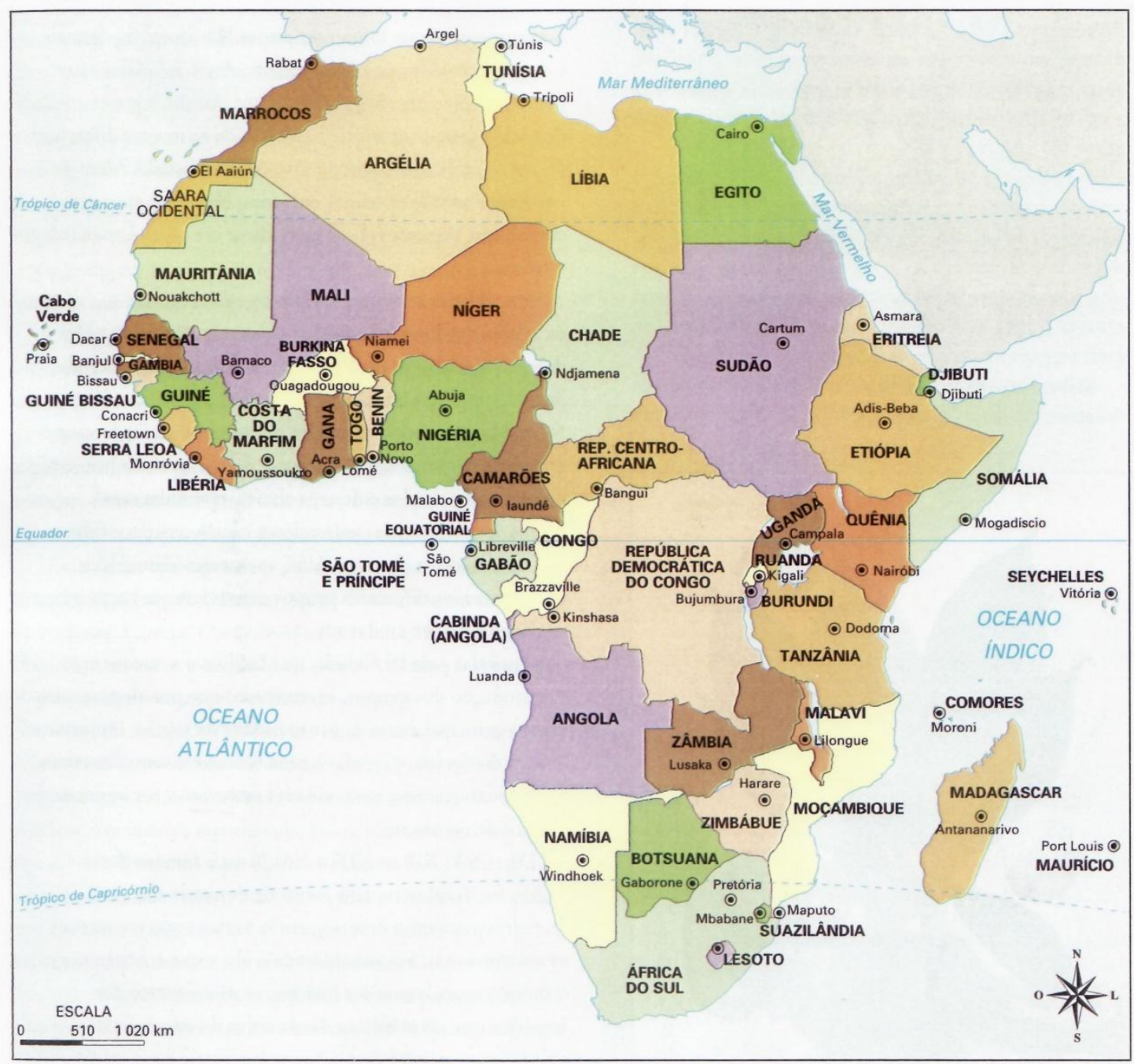




\subsection{MOÇAMBIQUE: A EMERGÊnCIA DE UMA NAÇÃO E SUA ENTRADA NO MERCADO DAS ARTES}

Maputo, situada na África Austral, é capital da República de Moçambique. Com 23.049.621 habitantes de acordo com o censo de 2011, Moçambique tem uma área de $799.380 \mathrm{~km}^{2}$ e o seu território organizado em províncias. As capitais e suas dez províncias são: Cabo Delgado (Pemba), Gaza (Xai-Xai), Inhambane (Inhambane), Manica (Chimoio), Nampula (Nampula), Niassa (Lichinga), Sofala (Beira), Tete (Tete), Zambézia (Quelimane) e finalmente Maputo (de mesmo nome que a capital). No mapa 1, têm-se assinaladas a capital do país, Maputo, Sofala (capital Beira), Nampula (capital de Nampula) e Cabo Delgado (capital Pemba), outras principais cidades do país.

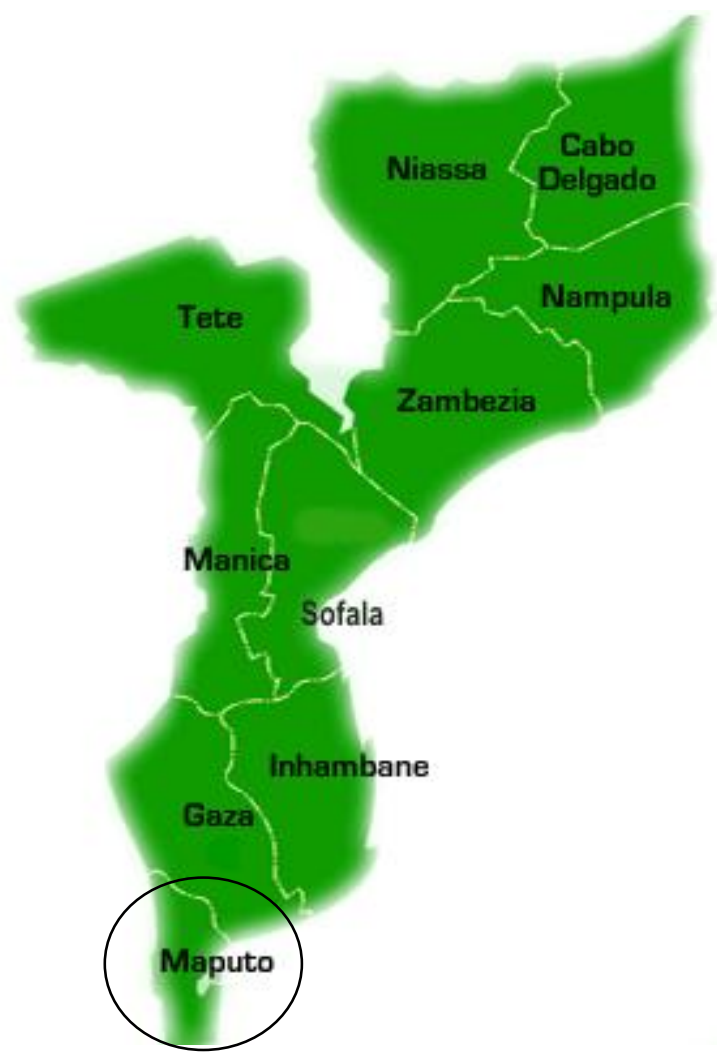

República de Moçambique Localização:

Sudeste Africano; faz fronteira com África do Sul, Tanzânia, Malawi, Zâmbia, Zimbábue e Suazilândia.

Área: 799.380 km²

*População: 23. 049.621

(2011)

Clima: Intertropical

Língua Oficial: Português

Mapa 2

Localização geográfica da República de Moçambique e de sua capital, Maputo, em relação a outras cidades importantes. 
Após os dados iniciais, apresentamos um esboço histórico e um alinhamento dessas bases para a compreensão desta realidade tão próxima e ao mesmo tempo tão distante de nós.

Pensar sobre as origens da África é sem dúvida um grande desafio, visto que ainda existem lacunas a serem consideradas, como nos chama a atenção KIZERBO; o autor traz à baila inúmeras questões, desde a concepção da própria história, e a necessidade em seus primórdios da aceitação da sua oralidade, que é o ponto a ser considerado aqui pelo autor;

De facto, a historiografia africana entra em cena num momento em que se opera uma revolução na concepção geral da história. Cada vez menos os autores e os leitores de história se interessam pela história historizante das datas de batalhas e dos anos de reinado. A história quer abraçar em amplidão e em profundidade o caudal do evoluir humano. ${ }^{34}$

Esta concepção da História com uma visão humanista, pleiteada pelo historiador, vem ao encontro das expectativas propostas nesta pesquisa. As bases da história africana têm raízes profundas e propiciam amplo aspecto analítico para a realidade moçambicana.

Em períodos anteriores ao século XVIII, Moçambique vinha sendo constantemente submetida a processos de ocupação do seu território e de exploração. Para citar um exemplo, o papel da Inglaterra com a sua entrada na era industrial, é uma constatação neste movimento de força e de estratégia em ação na ocupação do continente africano por um representante ocidental, porém este país não foi o único. Ao analisarmos apenas o papel da Inglaterra entenderemos uma parte significativa das relações políticas e econômicas que são implantadas na África desde tempos memoráveis, pois isso está amplamente documentado. É importante também creditar a inserção de outros países, como já salientado, além da Inglaterra, neste cenário, como França, Portugal e Alemanha.

A Inglaterra faz três movimentos fundamentais: o primeiro deles, no século XVIII, quando da implementação da Revolução Industrial, como já dito, detentora de reservas de carvão e de ferro. Com uma política fortemente ligada à substituição da mão de obra pela automação da produção ${ }^{35}$, através da substituição de uma parcela

\footnotetext{
${ }^{34}$ ZERBO-KI, Joseph. Op. cit., p. 18.

${ }^{35}$ No sentido restrito ao econômico.
} 
do trabalho humano pelo processo automático, otimizando assim a produção e criando novas relações de valores. Neste aspecto FRIEDMANN analisa: "As máquinas exigem pouquíssimo raciocínio e nenhuma iniciativa ou responsabilidade no que se refere à quantidade e à qualidade" ${ }^{36}$, e é nesta escalada mecânica que a Inglaterra se impõe mais uma vez em relação a outras nações.

Configura-se nesta perspectiva a história do ocidente em relação aos demais países, até hoje. (Considerando-se anteriormente no âmbito de Moçambique a fase aliada ao mercado e seu impacto ${ }^{37}$, e salientando posteriormente o comércio do marfim e do ouro causando a expansão da colonização portuguesa como de outros países.)

O segundo passo, quando se torna o primeiro país a promover o fim do tráfico negreiro $^{38}$, no início do século XIX, aliando-se nesse momento aos portugueses no combate em costa moçambicana, porém com interesses econômicos e não humanistas como querem fazer crer.

KI-ZERBO traça uma discussão capital sobre o tema, ao escrever:

No alvorecer do século XIX, a África, sangrada de todos os lados, desde há quatro séculos, pelo tráfico negreiro, atrai cada vez mais a atenção do mundo. Porquê? (sic) Em primeiro lugar, por causa do movimento contra a escravatura. Lembremos que a Grã-Bretanha, depois de suprimir a escravatura no seu imenso império, em 1830, monta a guarda nos três mares em volta da África. Em 1848, a França faz o mesmo. Embora o Brasil tenha esperado até 1898 para seguir a corrente, desde meados do século XIX que o tráfico de escravos já não está em moda e será cada vez mais banido. $^{39}$

Mas esta postura diferenciada em relação à exploração econômica e humana do continente africano é uma mudança de paradigma bem maior: em primeiro lugar por que a Inglaterra toma a iniciativa em relação ao tráfico negreiro? Justamente

${ }^{36}$ FRIEDMANN, Georges. O Trabalho em Migalhas. Ed. Perspectiva, São Paulo, 1983, p.89.

37 "Entre os séculos IX e XIII encontramos evidências de uma progressiva e lenta fixação de populações provenientes principalmente do Golfo Pérsico, o qual era um dos principais centros de comércio no índico no século X", apud SERRA, Carlos, História de Moçambique, Vol. I. In SERRA, Carlos (dir.), Maputo: Departamento de História, Universidade Mondlane, 2000, p. 24.

38 "Se no final do século XVIII saíram de Moçambique de quatro a cinco mil escravos por ano, entre 1815 e 1820 calcula-se que saíssem anualmente com destino ao Brasil cerca de dez mil e, com destino às ilhas francesas do Índico (Bourbon e Reunion), cerca de sete mil. Entre 1815 e 1820 só do vale do Zambeze e da área dos Prazos, eram escoados cerca de 2500 escravos por ano e, por volta de 1820, atingia-se os quatro mil." Apud SERRA, Carlos, op. cit., 2000, p.81.

${ }^{39}$ ZERBO-KI, Joseph. História da África Negra, Vol. II Publicações Europa-América, Portugal, 2002 p. 67. 
porque é na Inglaterra, como já vimos, que ocorre o maior fenômeno da era moderna - A Revolução Industrial, e com ela o que vários teóricos e literatos irão denominar como o espetáculo da multidão: trazendo para as cidades os personagens pobres e vagabundos, os párias, um grande êxodo do campo para a cidade é computado, ou seja, é mais uma vez a roda da economia a girar! Inicia-se a especialização dos saberes e o aumento do consumo, necessita-se de mão de obra barata.

Paralelamente, através da visualização do mapa 3, África Colonial (1900), já no século XX, note-se que a Inglaterra e a França são os países com mais colônias no continente africano e, dentro do contexto global, as primeiras nações a entrar na era da indústria, movimento iniciado já no século XVIII e que vai se consolidando como um projeto de expansão e exploração, terceiro passo.

Portanto, a colonização da África no século XIX é novamente mais uma peça a ser movimentada no jogo dos interesses econômicos, porque, como notamos, a Inglaterra e a França, os primeiros a porem fim à escravatura também são os principais interessados na nova dinâmica instalada pela tecnologia e pelas novas relações de trabalho, que darão suporte necessário para estes dois países colonizarem o continente africano. Inicia-se também a próxima etapa, a expansão do imperialismo, que traz em seu cerne a ideologia capitalista. Segundo SERRA, a reunião de critérios é feita pela acumulação de capital, a procura de matérias-primas e a exportação de capitais. ${ }^{40}$

O autor cita a Conferência de Berlim ${ }^{41}$ como a formalização política da partilha do continente e sua consentida exploração, somando-se ao que vem sendo relatado. SERRA diz:

No século XIX, a acumulação generalizou-se. A revolução industrial, ao expandir-se, tornou típica e geral a acumulação nas economias de países

\footnotetext{
${ }^{40}$ SERRA, Carlos. Op.cit., p.154.

41 "A "Conferência de Berlim", realizada em 1884/5 entre as grandes potências europeias, ocupou-se da discussão da "questão colonial" e foi um processo para se chegar a um acordo, à mesa das conversações, sobre o delineamento das fronteiras, com o fim de se evitarem, no futuro, conflitos armados. A partilha da África, aquela que passou a vigorar nos mapas, não se fez verdadeiramente em Berlim. Ela principiara já, e prosseguiu depois. O que se tentou fazer em Berlim foi obter um acordo de princípios entre as diversas potências concorrentes." apud SERRA, Carlos, op. cit., 2000, p.161.
} 
como a Inglaterra, primeiro, e depois a França, a Bélgica, a Alemanha, os Estados Unidos da América e o Japão. ${ }^{42}$

Dando um salto no tempo, poderíamos dar inúmeros exemplos entre as relações históricas entre Ocidente e Oriente, mas é nítida, na década de 1960, a revolta por parte dos africanos colonizados, destituídos de todas as suas formas de estar no mundo, sejam elas tanto nas instâncias econômicas como nas culturais. BERGH analisa a situação:

Moçambique ficou independente em 1975, quinze anos depois da maioria das colônias britânicas e francesas em África. Nessa altura Portugal estava ainda debaixo do regime ditatorial do seu poderoso primeiro-ministro António Salazar, a quem Marcelo Caetano sucedeu mais tarde: as colônias eram consideradas províncias portuguesas em África. Famílias pobres de Portugal tinham vindo para Moçambique, tomando a terra e os empregos e criando acesso a saúde e a educação apenas para eles próprios. ${ }^{43}$

Desprovidos de sua autonomia territorial e simbólica, os moçambicanos passam neste processo a constituir-se como Nação e como identidade nacional através de constantes lutas (Fig. 5; destacam-se o primeiro presidente de Moçambique Samora Machel e o seu Vice-Presidente Joaquim Chissano), inclusive lutas identitárias como salientamos e constatamos na análise de BERGH.

A formação da história dos continentes é uma repetição constante de histórias de dominação e exploração, e os laços da diplomacia são patentes, como notamos na Fig. 6, com Lorde Curzon, representante do governo britânico na Índia e o marajá de Petíala; no continente africano esta política de aproximação e de jogos de interesses não foi diferente.

Para ter-se a dimensão do que isso representaria a partir da década de 1960 na África, CANÊDO registra;

\footnotetext{
Nesta década, trinta nações africanas irromperam no cenário mundial. Só nos doze primeiros meses da década, conhecidos como "O Ano da África", dezessete países conseguiram sua independência política; Camarões, Congo Francês e Congo Belga, Gabão, Chade, República Centro Africana, Togo, Costa do Marfim, Daomé, Alto Volta, Níger, Nigéria, Senegal, Mali, Madagascar, Somália, Mauritânia e Suazilândia. ${ }^{44}$
}

${ }^{42}$ SERRA, Carlos. Op. cit., p.154.

43 BERGH. Lucia Van den. Porque prevaleceu a paz, Moçambicanos respondem. Editora Annick Osthoff, Parlamentares Europeus com África, AWEPA. Moçambique, p.14-15, s/d.

44 CANÊDO, Letícia Bicalho. A Descolonização da Ásia e da África: processo de ocupação 
Adentrando na questão principal, após um breve percurso histórico, encontramo-nos entre o segundo quartel do século XX e o início do século XXI. Não há mais discussão sobre a viabilidade do capitalismo, este, é fato, está consolidado, os países africanos ainda estão situados na pós-revolução, sem uma indústria de relevância, com poucas possibilidades de crescimento econômico, com exígua agricultura, porém com traço artístico.

Obteremos uma visualidade até os dias atuais, primeiro apontando alguns aspectos da arte tradicional, o que foi imediatamente absorvido nos contextos exteriores ao continente africano. Em seguida, a arte africana contemporânea, através da apreciação de quatro exposições comentadas e dos principais artistas atuantes, e do trabalho de Kiluanji Kia Henda (Fig. 2), de Angola, e de Alberto Tavares (Fig. 3), de Cabo Verde.

Após um panorama geográfico e histórico de Moçambique, nos aspectos que tangem à cultura, aprofunda-se o repertório visual trazendo a arte tradicional moçambicana. A realidade percebida neste território testemunha a divisão dos grupos étnicos e reflete a divisão geográfica virtual, uma vez que esta divisão foi decidida sem o conhecimento empírico da região, efetivada na Conferência de Berlim, o que pode ser conferido quando da análise histórica de Moçambique, como dos demais países africanos.

Esta divisão muitas vezes de um mesmo povo diminuiu então sua capacidade enquanto comunidade detentora de saberes e formadora de culturas; exemplo desta divisão são os Macondes, que foram divididos entre a atual Tanzânia e Cabo Delgado.

Detecta-se uma pluralidade e ao mesmo tempo uma unidade na arte nomeada como tradicional entre os grupos dos Macondes, os Macuas, os Tsongas e os Nyungwes, mesmo com esta divisão espacial dentro do território moçambicano.

Um dos aspectos positivos foi o intercâmbio entre os diferentes grupos, trazendo e levando informações, considerando-se a mobilidade pelo território nacional, mais difícil de impedir e controlar, e uma cultura ligada à tradição da oralidade.

colonial:transformações sociais nas colônias: os movimentos de libertação, Atual: São Paulo,Campinas, Universidade Estadual de Campinas, 1985, p. 33. 

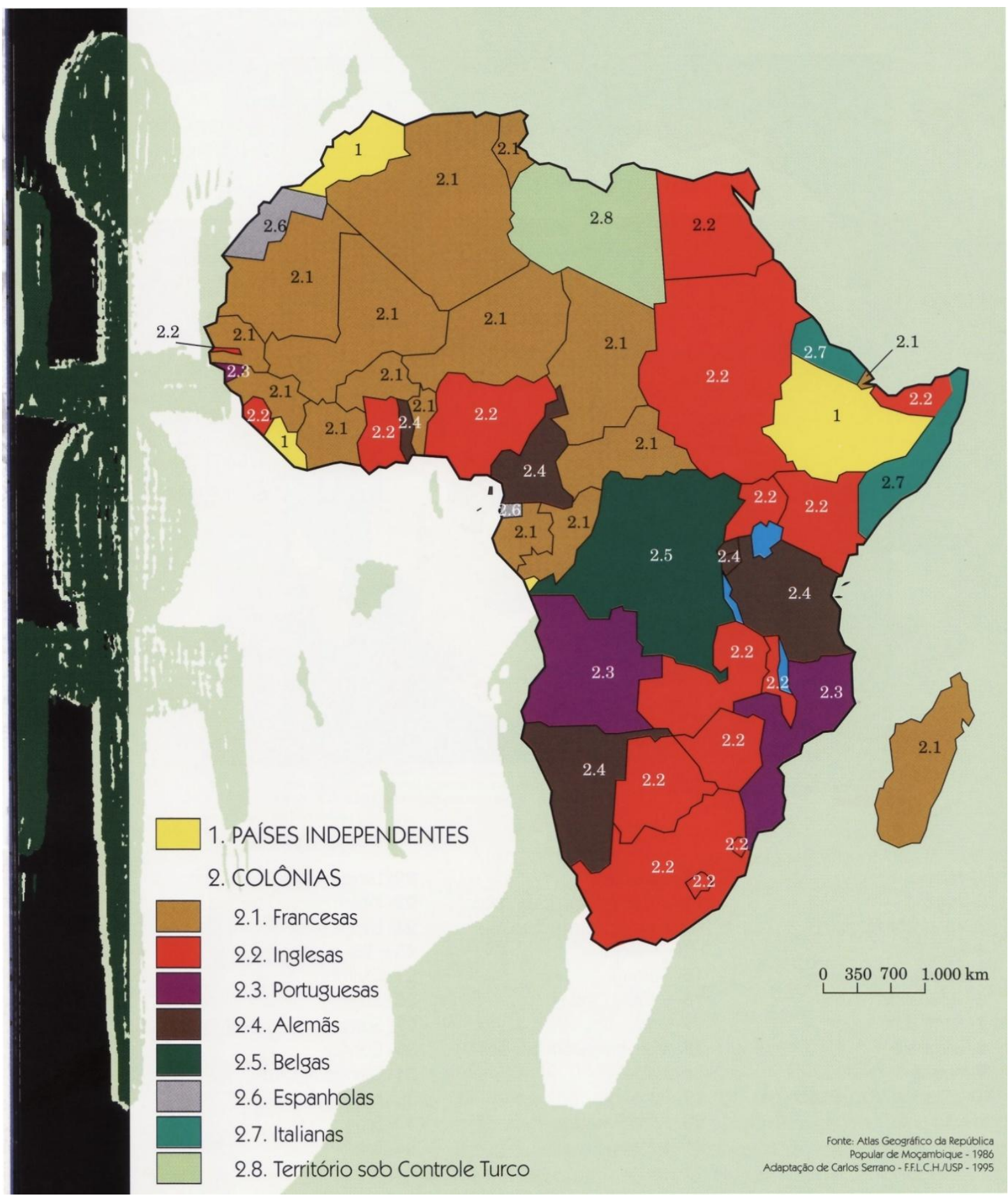

Mapa 3 África Colonial (1900 d.C.) 


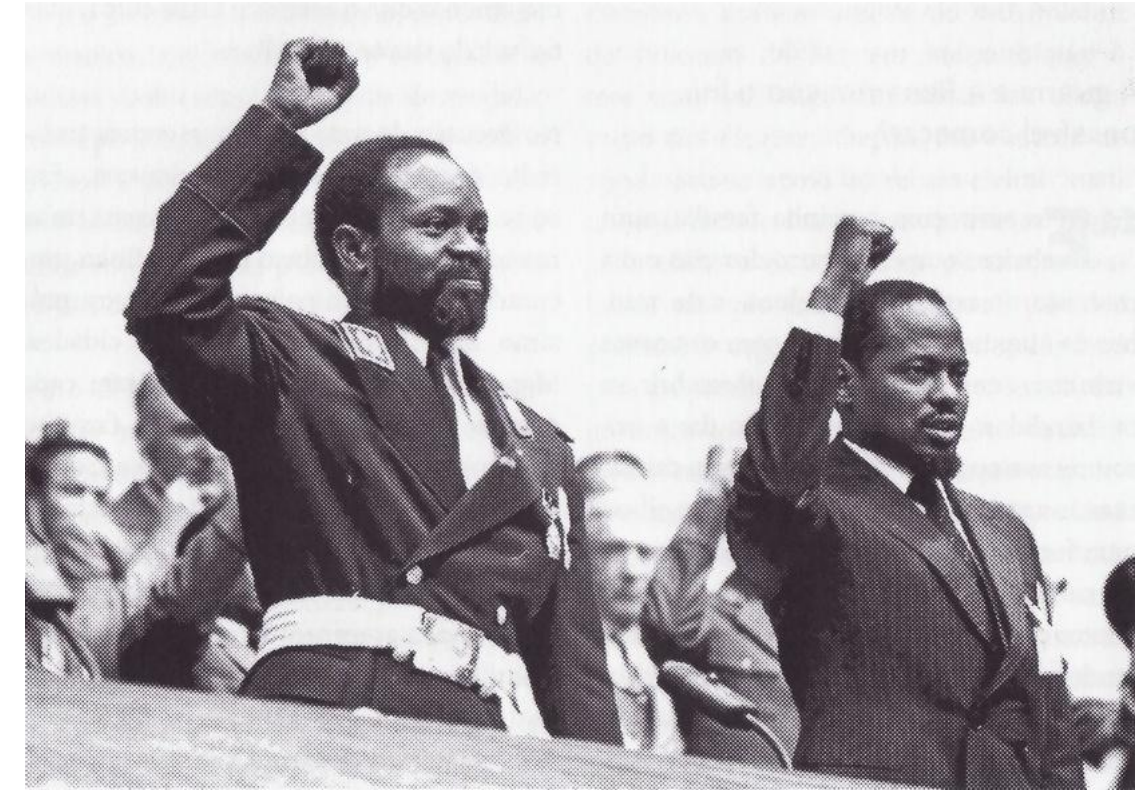

Figura 5. Samora Machel, o primeiro Presidente de Moçambique. À direita: Joaquim Chissano (AIM).

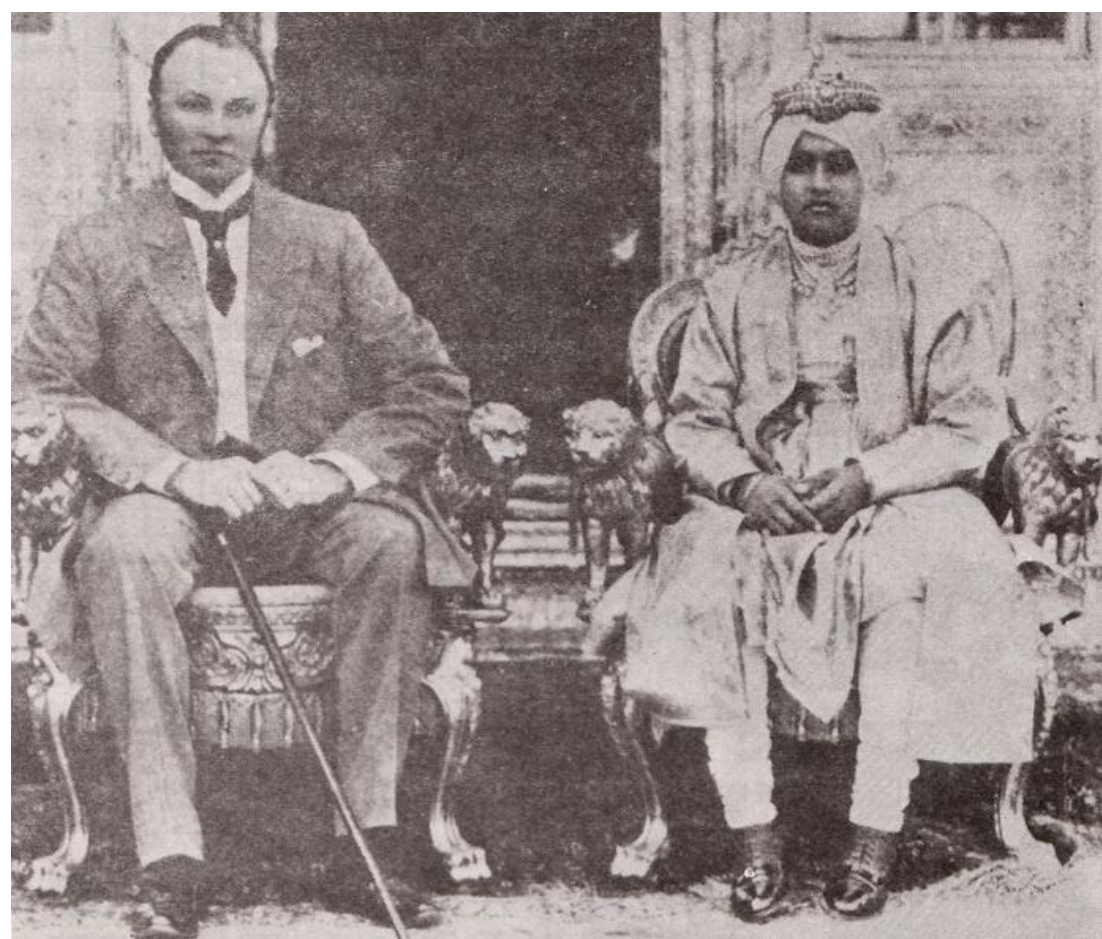

Figura 6. "As potências coloniais apoiavam príncipes e chefes dispostos a colaborar com seus interesses. Na foto, Lorde Curzon, representante do governo britânico na Índia, e o marajá de Petíala." 
1.2. ARTE TRADICIONAL MOÇAMBICANA: MACONDES, MACUAS, TSONGAS E NYUNGWES

Moçambique tem seu território dividido entre diversos grupos étnicos, como os Macondes ${ }^{45}$, os Macuas, os Tsongas e os Nyngwes, (mapa 4) além de outros também distribuídos geograficamente (mapa 6).

Nesta perspectiva do conhecimento da arte tradicional produzida por estes grupos, a história oral e a sistematização do seu registro tornam-se de vital importância na manutenção do próprio sentido de comunidade dos grupos, dos saberes e da arte. A recuperação desta historiografia deu-se através dos principais pesquisadores sobre o tema, quais sejam; DIAS, MARTíNEZ, JUNOT e MAIA. O acesso a estes estudos pioneiros possibilitam hoje o conhecimento destes povos.

Do grupo estudado por DIAS, a primeira peça apresentada, a título de exemplo, denomina-se Máscara Elmo ${ }^{46}$ (Fig. 7), que pertence ao grupo dos Macondes e está alijada do contexto para o qual foi criada: cerimonial, e por isso distancia-se do próprio sentido da cultura material e imaterial que vem sendo perpetuado erroneamente através do tempo no inconsciente ocidental de várias formas, incluindo a exposição das peças africanas nos museus e instituições culturais.

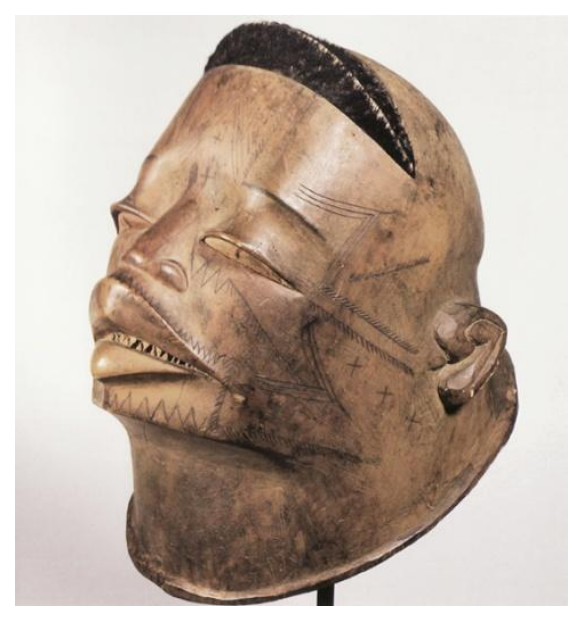

Figura 7 Máscara Mapiko

Makonde,Tanzania - Moçambique

Máscara Elmo

$27 \mathrm{~cm} / 10,6 \mathrm{~cm}$

Coleção privada

\footnotetext{
${ }^{45}$ A palavra foi encontrada em diferentes bibliografias consultadas com duas formas de grafia, ou seja, Maconde, em Português e Makonde em Inglês; iremos adotar as duas formas conforme as citações.

${ }^{46}$ Segundo DIAS, a palavra mapiko significa "pl. de lipiko, dançarino ritual de máscara", apud DIAS, Jorge. DIAS, Margot. Os Macondes de Moçambique, Aspectos Históricos e Econômicos, Vol. II. Junta de Investigações do Ultramar, Centro de Estudos de Antropologia cultural, Lisboa, 1964, p.167.
} 
Ainda sobre a Máscara Elmo, ou mais corretamente Máscara Mapiko, segundo documenta DIAS, o penteado e até mesmo o corte do cabelo que observamos neste objeto está interligado a esse grupo dos Macondes do Norte de Moçambique, sendo usado pelos rapazes em seus rituais de iniciação.

Além dos exemplos nomeados, vêm evidentemente as peças de cunho utilitário de beleza estética e que foram parar nas vitrines ocidentais como registro de um universo peculiar e classificadas como exóticas nesses ambientes, tanto quanto objetos de adorno como braceletes, tornozeleiras entre outros. Notadamente, a cestaria e a olaria são produções bastante recorrentes no quotidiano dos Macondes e dos outros grupos aqui apresentados como os Macuas e os Tsongas, entre outros.

Outro exemplo para aprofundar a discussão traz a peça Dança Mapiko (Fig. 8), máscara/objeto, contextualizada como parte integrante do vestuário, no momento da celebração de uma cerimônia ritual, o que reafirma a necessidade de mostrar o papel da máscara em um ambiente maior do que o que encontramos nos museus e exposições ocidentais, sendo feita para outro objetivo e não para estar em uma vitrina.

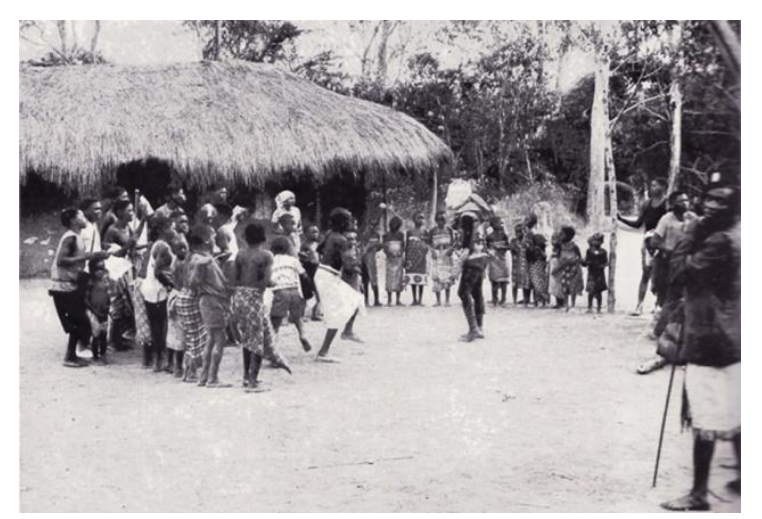

Corroborando com esta ideia sobre a arte africana tradicional e sua
Figura 8

Dança do mapiko na pequena povoação de Impueba, materialidade, SALUM conclui:

Portanto, a primeira coisa a reter é que, na África, cada estátua, cada máscara, tinha uma função estabelecida, e não eram expostas em vitrines, nem em conjunto, nem separadamente, como vemos nas vitrines dos museus. Outra coisa deve ser lembrada: a arte africana é um termo criado por estrangeiros na interpretação da cultura material estética dos povos africanos tradicionais, diferente das artes plásticas da África contemporânea 

que se integram, como as nossas, no circuito internacional das exposições.
47

A discussão acerca deste tema é grande e não existe ainda um consenso: é uma tentativa de conceituar uma produção artística ainda hermética em seus cânones estéticos, assim como ainda está em aberto um consenso também sobre a própria arte contemporânea. A estes conceitos se soma a necessidade de acessar o lugar onde operam, ou seja, a cultura, para compreender a visualidade que está sendo construída no continente africano e especificamente em Moçambique.

BALOGUN, sobre a natureza da obra de arte de modo geral, afirma:

Tem sido frequentemente dito que a arte era uma linguagem universal, capaz de franquear todas as distâncias e de transmitir uma mesma mensagem a todos os homens, fosse qual fosse a sua raça e a sua fé. Por mais sedutora que esta imagem possa parecer, não deixa, por isso, de ser verdade que, tal como muitas vezes o verificamos, numerosas obras de arte estão tão estreitamente ligadas aos factores sociais, históricos e culturais específicos das sociedades nas quais surgiram e se desenvolveram que não são imediatamente acessíveis àqueles que são estranhos ao meio no qual se formaram... 48

Apesar da universalidade dos sentimentos humanos que a obra de arte pretende carregar, outras obras pertencentes a grupos como os exemplificados aqui preservam seu conteúdo hermético. Por esta razão, vimos a necessidade de mapear o território moçambicano, trazendo a produção dos seguintes grupos: os Macondes, os Macuas, os Tsongas e os Nyungwe. Criamos três eixos de discussão, quais sejam: Norte, Sul e Centro-Oeste. A função principal e objetiva destes exemplos é favorecer a compreensão deste universo e posteriormente considerar possíveis elos conectores entre os trabalhos dos artistas moçambicanos e esta referência, permitindo uma ponte até a contemporaneidade.

Após a Máscara Elmo e a Dança Mapiko, (Figs. 7 e 8), vimos também a necessidade de comentar a Arquitetura Maconde, que privilegia a construção circular (Fig. 9), também encontrada em outros grupos moçambicanos, como os Macuas, em um desenho arquitetônico mais esquematizado por MARTíNEZ (Fig.10).

47 SALUM, Marta Heloísa Leuba. África: Culturas e Sociedades, Guia temático para professores. Museu de Arqueologia e Etnologia da Universidade de São Paulo, São Paulo, 2008, p.14.

48 BALOGUN, Ola. "Forma e expressão nas artes africanas." In: ALPHA, Sow; BALOGUN, Ola; AGUESSY, Honorat; DIAGNE, Pathé. Introdução à Cultura Africana. Lisboa: Edições 70, (s/1):Unesco, (Biblioteca de Estudos Africanos), 1977, p.37. 
Vale ressaltar que nos Macondes DIAS tenha identificado a forma retangular, considerada pelo autor menos usual.

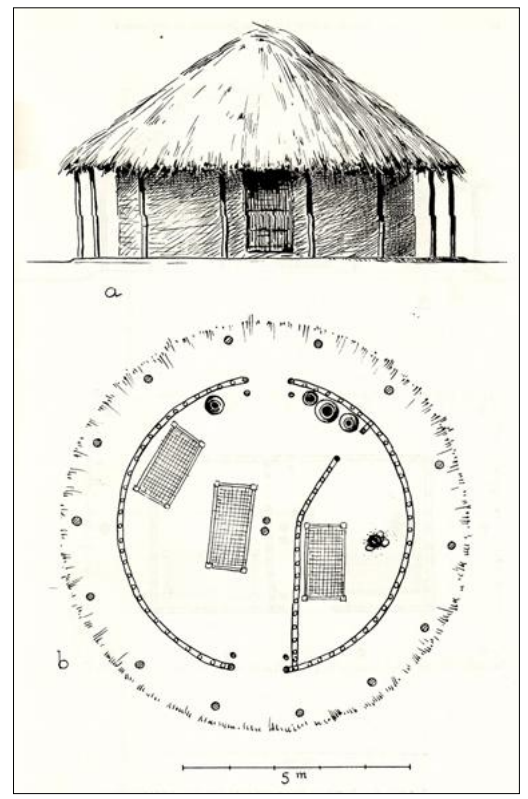

Figura 9 Aspectos da Arquitetura Maconde Planta de uma casa circular dividida em dois compartimentos e o telhado apoiado em pilares.

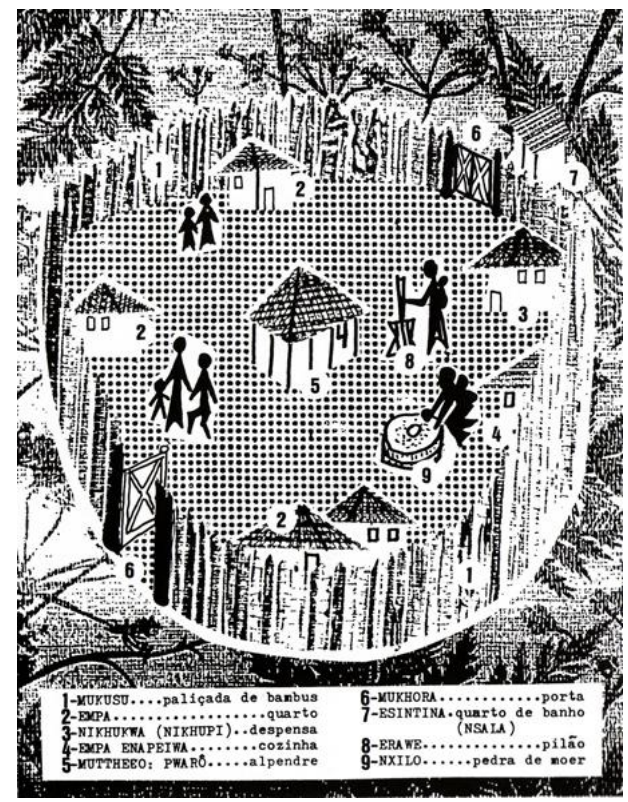

Figura 10 Aspectos da Arquitetura Macua "Ettoko", residência macua

A arte dos Shonas, outro grupo africano, encontra-se tanto no Zimbabwe como na África do Sul, regiões de fronteira com Moçambique, como exemplificada numa peça do acervo do Musée du Quai Branly, em Paris (Fig. 11). Notamos a grafia geométrica utilizada a qual mais tarde os artistas modernos no Ocidente irão apreciar tanto nas peças africanas.

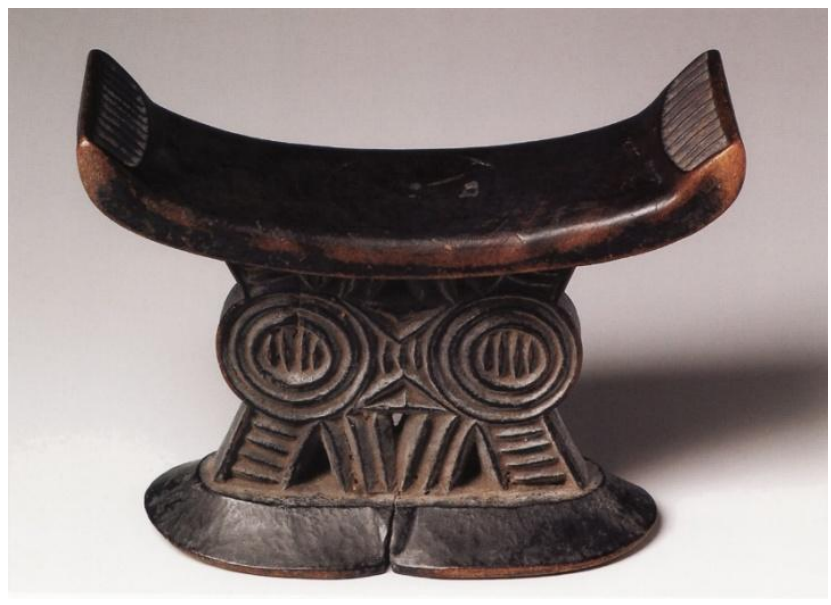

Figura 11

Shona, Zimbabwe e África do Sul Apoio de cabeça, madeira $19,3 \mathrm{~cm} \times 7,6 \mathrm{~cm}, 1872$ Musée du quai Branly, Paris 
$\mathrm{Na}$ obra de DIAS, selecionamos algumas considerações sobre os Macondes; este autor é um etnólogo e integrante de uma Missão de Estudos das Minorias Étnicas no Norte da Província de Moçambique, criada em 1957, ação essa empreendida pela Junta de Investigações do Ultramar, Centro de Estudos de Antropologia Cultural. Neste momento realça-se o comentário anterior sobre as expedições e missões na África, quando este território moçambicano ainda era considerado uma província ultramarina portuguesa. Com o objetivo de trazer ao Ocidente informações e a materialidade sobre este continente, especificamente a este respeito, DIAS justifica a escolha:

A viagem de prospecção que eu tinha feito nas nossas províncias ultramarinas, em 1956, permitiu-me escolher a região onde devia trabalhar a Missão. Depois de várias hesitações, decidimo-nos pelo povo maconde, no Norte de Moçambique. Era um povo pouco conhecido e que havia estado segregado do convívio ocidental e oriental até o fim da primeira grande guerra. $^{49}$

DIAS, um dos autores referenciais nesta área de pesquisa, alerta-nos sobre a diversidade cultural existente em Moçambique, mesmo entre os macondes. Seu estudo usará os fixados na área do Tanganica ${ }^{50}$, atual Tanzânia, apenas como grupo de comparação, pois fixa sua observação em Cabo Delgado. Como o autor, compreendemos que determinados traços são similares entre os dois grupos de macondes separados geograficamente, por obra da Conferência de Berlim além de outros eventos como as próprias guerras entre os grupos. Assim como os Nyungwe têm semelhanças com os Nyanjas do Malawi, como os Shonas do Zimbabwe, como também os Tsongas do Sul de Moçambique com os da África do Sul.

No mapa 4, é possível apontar a localização da Tanzânia e da África do Sul, em relação a Maputo, Moçambique. Mostramos algumas peças oriundas destas regiões fronteiriças como exemplares da arte africana considerada tradicional; e no caso dos Macondes um pouco da sua cultura material, como as escarificações. (Figs. 12 e 13).

\footnotetext{
${ }^{49}$ DIAS, Jorge. Os Macondes de Moçambique, Aspectos Históricos e Econômicos, vol. I. Junta de Investigações do Ultramar, Centro de Estudos de Antropologia cultural, Lisboa, 1964, p.7.

50 A palavra foi encontrada em diferentes bibliografias consultadas com três formas de grafia, ou seja, Tanganhica, Tanganica e Tanganika; iremos adotar Tanganica.
} 
Com estes exemplos pretendemos criar uma relação entre a cultura imaterial Maconde e posteriormente com a cultural material desse grupo, segundo o quadro esquemático abaixo, onde são postas lado a lado estas referências, (Figs. 12, 13 e 14) e sua reverberação na linguagem artística, ou seja, a intenção é afirmar que estes objetos são a própria cultura do povo Maconde, retratada inclusive pela artista Reinata Sadimba.

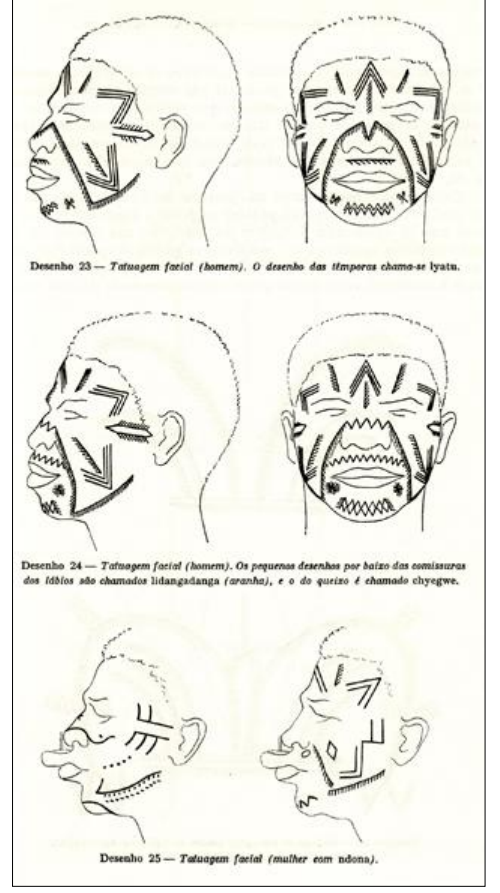

Figura 12 Escarificações,

Aspectos das escarificações MACONDES

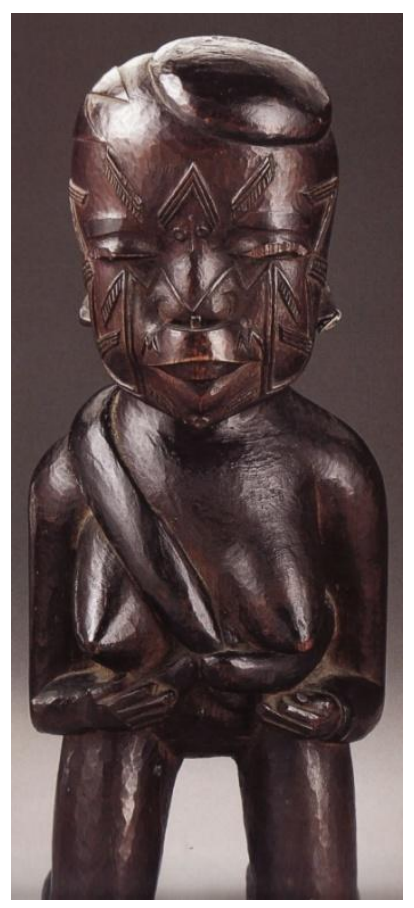

Figura 13 Makonde Maternidade, madeira $1880-190036,8 \mathrm{~cm} / 14,4$

Kimbell Art Museum, Fort Worth (TX)

Aspectos da escultura Maconde relacionada à cultura da escarificação.

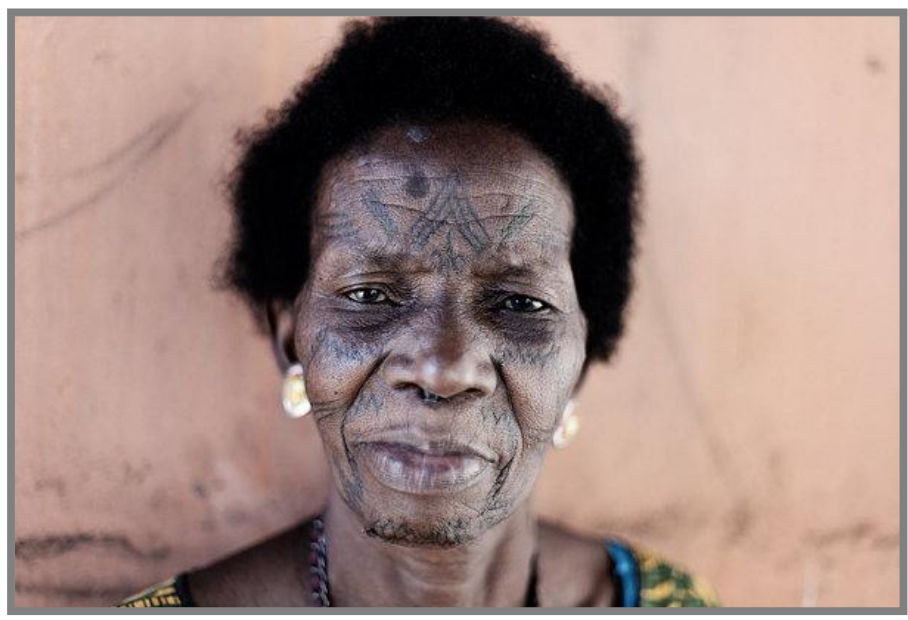

Figura 14

Reinata Sadimba 


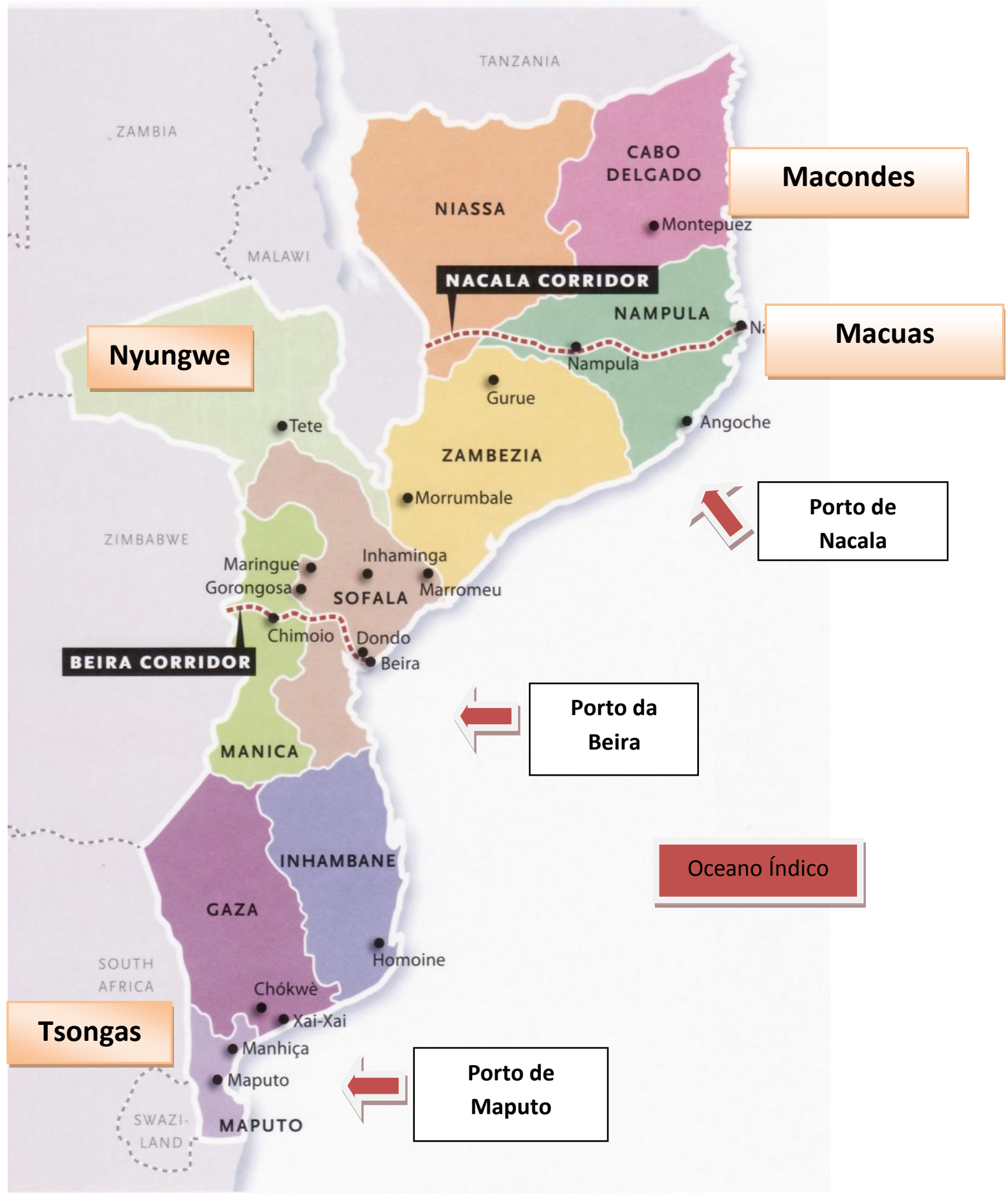

Mapa 4

Mapa de Moçambique ${ }^{51}$

${ }^{51}$ BEIRA E NACALA CORRIDOR - vias terrestres de escoamento da produção. Não foram feitos Corredores dentro do território moçambicano que ligassem as regiões Norte, Sul e Centro até hoje como mostra o mapa 4. A localização dos grupos é uma adaptação do Mapa de BERGH, op. cit., s/d, contracapa. 
A influência do colonialismo sobre a sociedade moçambicana, tanto no setor econômico com a obrigação de cultivar algodão ${ }^{52}$ e arroz, quanto no que tange às culturas materiais e imateriais propriamente ditas, causaram prejuízos e emigrações para as minas, na África do Sul e Rodésia do Sul, atual Zimbabwe, e para grandes fazendas, em busca de trabalho remunerado, uma vez que o seu sistema de organização social e de sobrevivência se havia alterado profundamente. Note-se a configuração do mapa 4 e a localização dos Portos de Maputo, Beira e Nacala, que se tornaram estratégicos e alvo de acordos e disputas.

À parte as questões econômicas, no que se refere à arte observa-se em alguns artistas do Movimento de Arte Contemporânea de Moçambique, MUVART, que é possível criar relações da arte tradicional com a contemporânea através da observação da produção artística de alguns grupos étnicos, considerando a tese de BALOGUN sobre a compreensão do universo artístico a partir da compreensão da sua cultura. Em alguns artistas moçambicanos faz-se necessária a adoção desta metodologia apontada pelo autor. Caso especifico da escultura maconde e da inserção da artista Reinata Sadimba, oriunda do planalto de Mueda, na província de Cabo Delgado, emigrante deste grupo comparativo eleito por DIAS. Ver mapa 4.

Documentando a cultura Maconde, o etnólogo denominou em seu capítulo Cuidados com o Corpo, no item decorações da pele, algumas definições que iremos resumir aqui, citando o autor:

\footnotetext{
Pintura - não afecta a estrutura epidérmica, pelo que se pode considerar uma decoração temporária.

Tatuagem - é a pintura permanente da pele que resulta da introdução de pigmento sob a pele, deixando-a lisa.

Escarificações - a cicatrização consiste em arranhar, escarificar, furar ou queimar a pele, dando lugar a formação de cicatrizes... Os Macondes usam sobretudo o sistema de cicatrização, decorando o corpo por meio de golpes, nos quais esfregam pó de carvão vegetal. ${ }^{53}$
}

As escarificações que marcam a face do objeto, máscara e escultura (Figs. 7 e 13), assim como no quadro esquemático (Figs. 12,13) mostradas anteriormente,

\footnotetext{
52 NEVES, Angelina. Viagens com a cabaça mágica, Nampula, vol.4, Ed.Coopimagem, Maputo, Moçambique, 2002, p.23.

${ }^{53}$ DIAS, Jorge e DIAS, Margot. Os Macondes de Moçambique, Aspectos Históricos e Econômicos, vol. II. Junta de Investigações do Ultramar, Centro de Estudos de Antropologia Cultural, Lisboa, 1964, p.56.
} 
também são representações do real, tendo em vista que os macondes as usam de fato e que podemos notá-las também na pele da artista Reinata Sadimba. DIAS reporta-nos que estes desenhos são usados por ambos os sexos e em diversas partes do corpo: "O homem costuma tatuar a cara, o tórax, o abdômen, a região renal e os braços. A mulher tatua a cara, as costas, os braços, o abdômen, o púbis, as nádegas e as coxas" ${ }^{54}$. Segundo o autor, com um jargão datado elas podem ter funções sobrenaturais - grifo nosso - e decorativas, embora DIAS acrescente que o sentido espiritual vem se diluindo. Não saberíamos confirmar esta hipótese, mas podemos notar que já não são tão usuais na atualidade.

Percebemos, no segundo grupo que iremos abordar, os Macuas, que eles também praticam a tatuagem. Segundo os relatos de MARTíNEZ, a tatuagem (ENEPO) está ligada aos ritos de iniciação. Transcreve o autor sobre este tema;

A tatuagem das mulheres macuas tem variadas formas: linhas curvas ou rectas e figuras geométricas (círculo, triângulos e pequenas linhas) ou simplesmente marcas na pele. No rosto, fazem-se três incisões ou mais, conforme o caso, nas bochechas, resultando cicatrizes longitudinais, em relevo, e escuras, de aproximadamente $3 \mathrm{~cm}$.

Entre os macuas, utilizam-se três técnicas diferentes para a tatuagem:

- $\quad$ Picar ou pontuar a pele com agulhas e substâncias cáusticas;

- Riscar com estilete e cinzas, obtendo uma espécie de baixo relevo na pele;

- Impregnar com material colorante uma zona subepidérmica limitada, para obter manchas escuras ou azuladas.

As partes do corpo da rapariga mais comumente escolhidas para a tatuagem são, para além da cara, como já disse, o peito, a barriga e o púbis. ${ }^{55}$

Portanto, com a descrição de MARTíNEZ, inicialmente observamos aspectos similares entre os grupos mencionados acima, tal como DIAS relatou sobre os Macondes, fixados no Tanganica, atual Tanzânia, e em Cabo Delgado, Moçambique.

${ }^{54}$ DIAS, Jorge. Os Macondes de Moçambique, Aspectos Históricos e Econômicos, vol. I. Junta de Investigações do Ultramar, Centro de Estudos de Antropologia Cultural, Lisboa, 1964, p.59.

${ }^{55}$ MARTíNEZ, Francisco Lerma. O povo Macua e a sua cultura: Análise dos valores culturais do povo Macua no Ciclo Vital, Maúa, Moçambique 1971-1985. Maputo, Moçambique: Paulinas, 2ª edição, 2008, p.124. 
Conectados com a perspectiva da cosmovisão africana, os valores morais surgem no seio dessa comunidade e fundamentam a existência e permanência de tais grupos, até os dias atuais.

Os Macuas, fixados no território moçambicano, são considerados o grupo étnico mais numeroso do país; divide-se em três segmentos religiosos: Religião Tradicional Africana, Islão (sic) e Cristianismo, segundo testemunha MARTíNEZ.

Em relação à sua situação geográfica, o autor informa:

O povo macua vive, actualmente, numa grande área do Norte de Moçambique, com cerca de $300.000 \mathrm{Km} 2$, que abrange parte das províncias de Cabo Delgado, Niassa, Nampula e Zambézia... A região, conhecida tradicionalmente pelo nome de "Macuana" ou WA-AMPHULA, é delimitada, a norte, pelo rio Rovuma; a leste, pelo Oceano índico; a sul pelo rio Licungo, nas proximidades do rio Zambeze; e oeste, pelo rio Lugenda.

Com uma população de 3.500 .000 habitantes, segundo cálculos baseados no recenseamento de 1980 , os Macuas constituem $35,6 \%$ da população total de Moçambique, sendo o grupo étnico mais numeroso do País. Os Macuas têm fronteira, a norte, com os Macondes, os Ayao e os Anyanja; a sul com os Senas e os Chuabos; e com grupos islamizados, no litoral índico... ${ }^{56}$

A pesquisa de MARTÍNEZ cobre o período de 1971 a $1985^{57}$ e todos os aspectos da vida quotidiana dos Macuas. O antropólogo capta o universo cultural desta comunidade, que se fixou no distrito de Niassa, como podemos observar no mapa 5, no qual notamos geograficamente a proximidade com os Macondes. A dimensão e a variedade dos grupos dentro do território moçambicano foi pontuada por MARTÍNEZ (mapa 6); destacamos apenas alguns deles: os Bitonga, Chope, Shona-Nyai entre outros. O objetivo central da eleição dos grupos descritos na pesquisa é cobrir as áreas Norte, Sul e Centro-Oeste de Moçambique.

\footnotetext{
${ }^{56}$ MARTíNEZ, Francisco Lerma. Op.cit., p.37.

${ }^{57}$ Considera-se a data das aferições numéricas.
} 


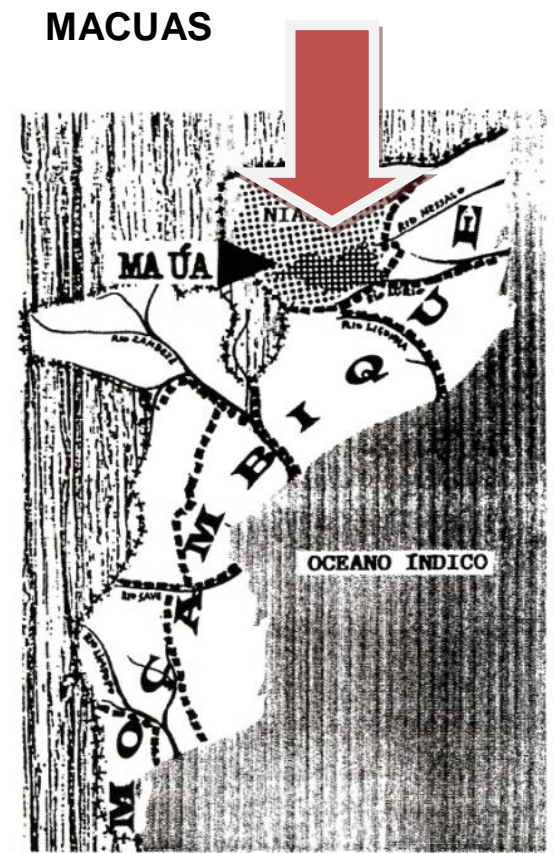

Mapa 5 Localização Geográfica dos Macuas Moçambique, Maúa.

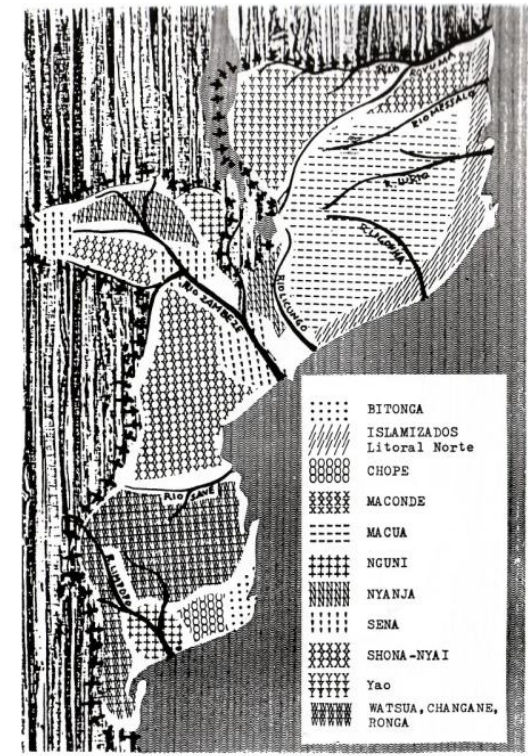

Mapa 6 Povos Moçambicanos Moçambique, povos

MARTÍNEZ atesta a existência da arte rupestre ${ }^{58}$; estações arqueológicas encontradas nesta região, e comentadas por ele, demonstram que há uma possibilidade de terem existido outras ocupações anteriores aos Macuas nesta região.

As características da produção artística dos Macuas propriamente dita estão imbricadas na vida quotidiana, na cestaria e na olaria, tal qual os Macondes, apesar de outros aspectos fazerem parte do universo cultural como a música, a dança, a pintura e a decoração corporal (Fig. 15), onde NEVES explica a origem da pintura no rosto das mulheres Macuas.

\footnotetext{
${ }^{58}$ Estações arqueológicas de arte rupestre em Moçambique; “... Monte Malunbué, cerca de $45 \mathrm{~km}$ de Lichinga, na Província de Niassa. Pinturas rupestres de Samo, os sítios arqueológicos de Zamgaia, Chicolone e Chifumbazi, todos na Província de Tete. Na província de Manica além das pinturas de Chinhamapere, são ainda conhecidas as do Monte Chimbanda na Serra de Zembe, ao sul de Chimoio...", texto adaptado de VELOSO, Helena, ALMEIDA, Luís de. Educação Visual, Maputo:Plural Editores, s/d, p.46.
} 


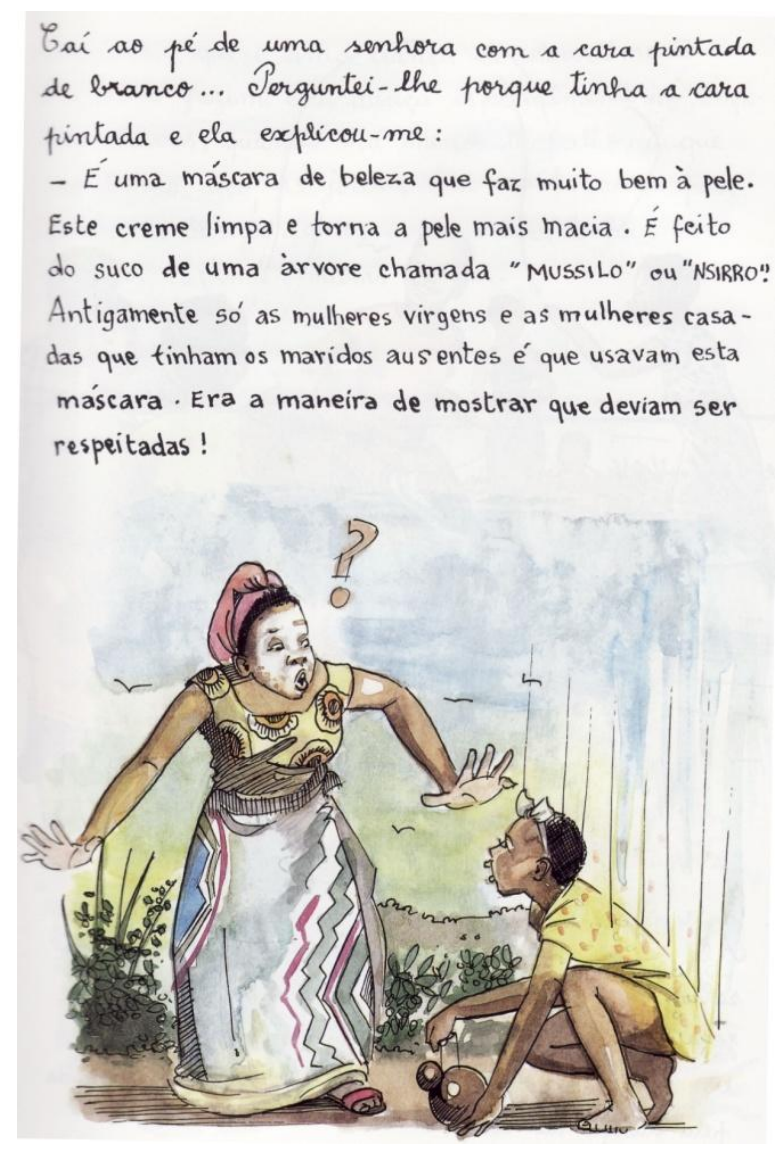

Figura 15 MACUA, povos.

Exemplo de decoração corporal

Os Tsongas localizam-se ao Sul de Moçambique e também são subdivididos em Rongas, sendo organizados através do sistema patrilinear ${ }^{59}$. Assim como os Macondes, Macuas e os Nyungwe, este povo possui ritos de iniciação, como a maior parte dos povos africanos; trata-se da transmissão do saber, da introdução do jovem no mundo adulto.

Atendo-se à produção artística desse povo, JUNOD, em seu capítulo sobre $A$ indústria dos Tsongas, comprova a importância da olaria e sua confecção pelas mulheres, que constituem uma característica presente entre os demais grupos aqui comentados. Detalha, dentro desta perspectiva, a cestaria e, de forma igual e minuciosa, a escultura. Sobre a metalurgia acrescenta:

Quando e como entrou o ferro no país dos Tsongas? É provável que jamais o saibamos. A tradição quer que a população primitiva, a que cozia os

\footnotetext{
${ }^{59}$ Este sistema relaciona os grupos de parentes pelo gênero masculino; ao contrário o matrilinear o faz através da mãe.
} 
elefantes para os esquartejar, não tivesse conhecido instrumentos de ferro. Segundo certos informadores, a enxada de que outrora se serviam era um bocado de pau, muito duro, arrancado, não sei como, a uma espécie de palissandro chamado ntshiva. Os indígenas destas terras passaram da idade da madeira à idade do ferro. ${ }^{60}$

O autor segue sobre o tema; porém nós nos deteremos mais à frente, quando JUNOD documenta a Vida Literária e Artística, no tomo II de sua obra capital, sobre o aspecto musical. É importante acrescentar que esta fonte teórica utilizada por nós no âmbito do povo Tsonga é originária de um olhar europeu, sendo 0 autor ${ }^{61}$ etnógrafo e missionário suíço e tendo escrito nos anos finais do século XIX e nos iniciais do século XX. Contudo, considerando os vieses do seu discurso atrelado ao espírito da época, é notória a relevância do seu trabalho, a tal ponto que no limiar do século XXI ainda permanece como uma referência sobre o grupo, comprovando-se a existência de determinados ângulos da cultura Tsonga, como iremos tratar no exemplo da Timbila, a seguir.

Denominado pelo etnógrafo de "piano indígena", a timbila é um instrumento musical e compõe-se segundo relato de JUNOD de "dez teclas, de madeira muito dura, ligadas umas às outras por tiras de couro, sobre um quadro que consiste num ramo recurvado" (Fig. 16). Com este exemplo da representação cultural, e consequentemente artística, de um grupo moçambicano, e comprovadamente de sua diversidade, concluiremos a trajetória sobre a arte tradicional com os Nyungwe, que será apresentada a seguir.

\footnotetext{
60 JUNOD, Henri. Usos e Costumes dos Bantu, Editor Arquivo Histórico de Moçambique, Maputo, tomo II: Vida Mental, 1996, p. 122-123.

${ }^{61}$ Centro Cultural e Social Junod, inaugurado em 11 de abril de 2008, Ricatla, Moçambique.
} 


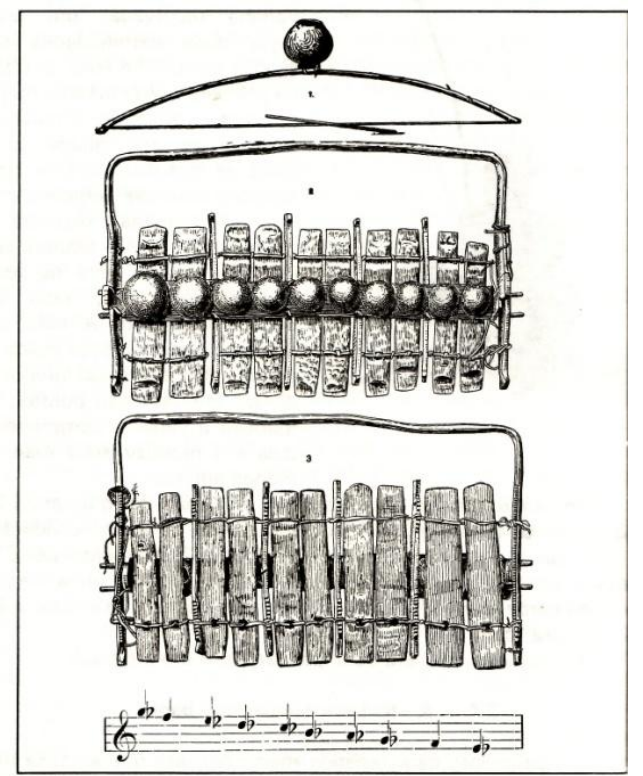

Figura 16

Tsongas, Timbila e as suas dez notas.

MAIA centra sua pesquisa nos Nyungwes, último grupo proposto localizado na região Centro-Oeste de Moçambique, com ênfase voltada para a compreensão da relação entre saúde versus doença versus cultura, mais uma vez revelando-nos a riqueza e a diversidade do cenário africano, em relação aos seus aspectos sócioculturais. Segundo o autor, além do português, Nyungwé é a língua que se fala em Tete, conforme mostrado no mapa 4.

Sobre sua localização explica o autor:

A província de Tete situa-se na região centro-oeste de Moçambique. É a única província moçambicana cercada por três países como o Malawi, a Zâmbia, e o Zimbabwe. Essas fronteiras conferem à província um lugar importante na geopolítica e na economia de toda a região da África Austral desde a época pré-colonial. ${ }^{62}$

Voltamos mais uma vez ao mapa 4, no qual podemos observar a localização geográfica dos Nyungwe. Além da situação espacial, um projeto de forte impacto na comunidade local e no País foi a construção da barragem de Cahora Bassa (Fig. 17) que dista $120 \mathrm{~km}$ da cidade de Tete. Construída por portugueses, é até hoje uma das barragens mais importantes da África.

${ }^{62}$ MAIA, Alone, Antonio. Saúde e Doença na Cultura Nyungwe: Um olhar Antropológico-Teológico, Mestrado em Teologia Sistemática, Pontifícia Universidade Católica de São Paulo, PUC/SP, São Paulo, 2011, p.22. 


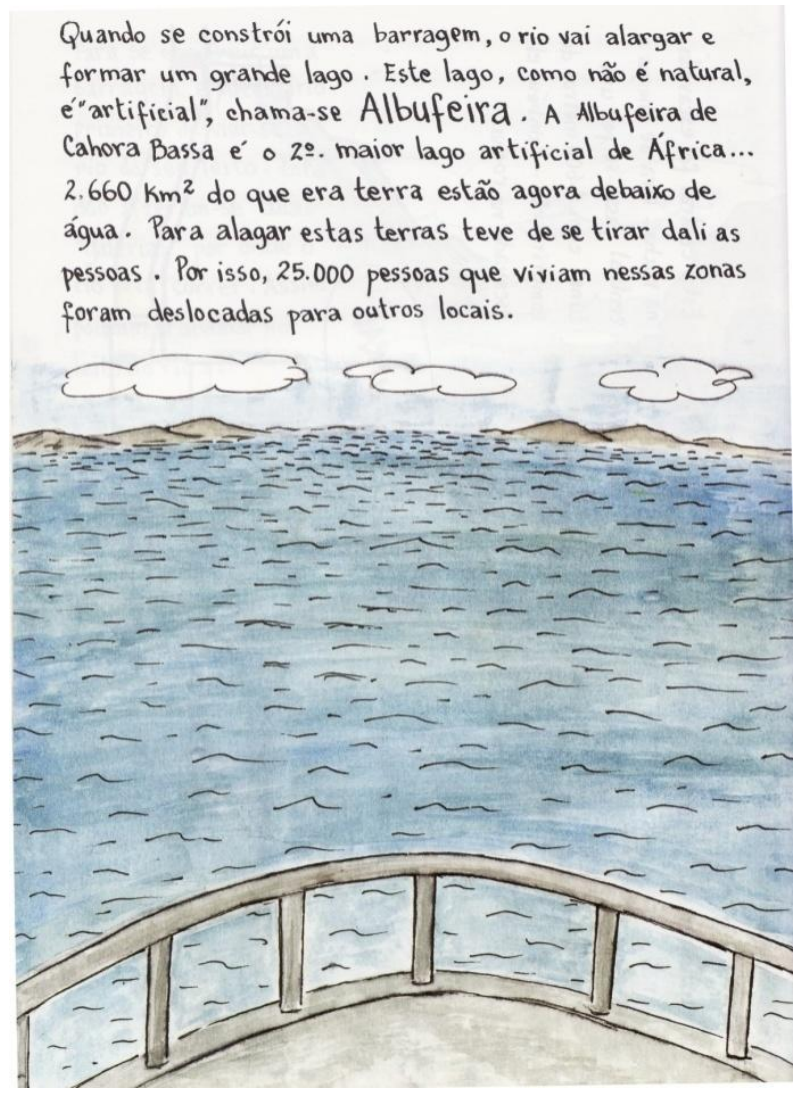

Figura 17 Barragem de Cahora Bassa

Em relação à importância desta barragem ABRAHAMSSON atesta:

... "A África do Sul tinha também a necessidade econômica estratégica de Moçambique. Tratava-se especialmente do acesso às infra-estruturas de transportes do país e da barragem de Cahora Bassa... O regime de Vorster recusou a proposta dos militares sul-africanos de entrar em Moçambique e apoiar os interesses coloniais portugueses que tentaram fazer um golpe de estado em Maputo...Este tipo de evolução poderia ameaçar seriamente a infra-estrutura de que a África do Sul tinha grande necessidade." ${ }^{63}$

A ausência de desenvolvimento de políticas nos setores estratégicos da economia como no incremento da estrutura no setor de transportes torna-se um dos principais fatores de estagnação do escoamento da produção do país e consequentemente salienta-se o papel fundamental dos portos.

Em relação à produção artística ressaltamos a estatuária Nyungwe fortemente ligada ao símbolo da fertilidade feminina. A maternidade neste grupo é um traço forte e somam-se à cultura tradicional elementos da medicina natural na utilização

${ }^{63}$ ABRAHAMSSON, Hans, NILSSON, Anders. Moçambique em Transição. Um estudo da história de desenvolvimento durante o período 1974-1992, Maputo, Moçambique, CEGRAF, 1994, p.76. 
de ervas e mesmo nas soluções de ordem cosmológica; porém, como atesta o estudo de MAIA, os Nyungwe aliam aspectos da cultura tradicional com as questões da contemporaneidade. Na estrutura da sociedade Nyungwe, a olaria, a cestaria e a aplicação de uma pintura no rosto como fazem os Macuas podem ser relacionados à produção de cunho mais estético e artístico.

O relato dos diferentes pesquisadores mostra um universo extremamente criativo entre os Macondes, Macuas, Tsongas e Nyungwe no domínio da solução de problemas quotidianos em resposta a anseios filosóficos dos homens.

A Arte africana ${ }^{64}$ produzida neste período, considerado anterior à colonização do continente, não era feita para ser vista, contemplada e analisada; por isso são raros os registros fotográficos, embora nos estudos realizados por DIAS, MARTÍNEZ, e JUNOT constem desenhos e fotos, o que auxilia também na compreensão destes grupos. Esta despreocupação em relação ao registro imagético da cultura atesta o sentido de integração com o quotidiano do grupo e da comunidade, onde o saber era passado às gerações seguintes principalmente pela oralidade.

Diferentemente da arte tradicional, a arte contemporânea é realizada para ser exposta e apreciada dentro dos parâmetros do que foi convencionado como museus e galerias, ou seja, nos espaços expositivos. Mesmo o resultado desta produção artística hoje classificada como obra de arte assume uma autoria que anteriormente tinha outro caráter no seio dos grupos sociais.

Neste sentido, outras modalidades de exposições e espaços arquitetônicos além dos descritos acima vão assumindo o cenário artístico já nos séculos $\mathrm{XX}$ e $\mathrm{XXI}$; por exemplo, as instituições culturais, sendo a maioria delas agregada aos setores bancários e corporativos.

Os artistas moçambicanos que precedem a geração dos artistas do Movimento de Arte Contemporânea de Moçambique, MUVART, são: Malangatana, Reinata Sadimba, e Victor Sousa.

A passagem por estes artistas se faz necessária, uma vez que os consideramos importantes na formação visual dos jovens artistas moçambicanos.

${ }^{64} \mathrm{~A}$ ideia de museu surge no Ocidente. 
A proximidade e a consequente referência estética que os artistas do Movimento de Arte Contemporânea de Moçambique, MUVART têm, como Malangatana, Reinata Sadimba e Victor Sousa, contemplam, além dos aspectos artísticos, os de engajamento político. Isto se deve ao fato de estes três artistas pertencerem a uma geração de moçambicanos que presenciaram de perto a transformação socioeconômica pela qual o país passava. Vale recordar que a independência moçambicana data de 1975, sendo assim um acontecimento histórico relativamente recente. Com exceção de Malangatana (com o qual tivemos contato), falecido em 6 de janeiro de 2011, os dois outros artistas moçambicanos continuam ativos e trabalham em proximidade com as linguagens contemporâneas. Com exemplos de arte tradicional moçambicana, e até mesmo de sua arquitetura, e, mais, dos três artistas apresentados, situados na década entre a revolução e a independência, traçamos um percurso destas grafias para a trajetória do Movimento de Arte Contemporânea de Moçambique, MUVART.

Esta construção imagética irá tratar desta cultura material e imaterial pelos artistas, e por vezes ainda trazendo um repertório hermético para as culturas ocidentais, que não possuem um repertório suficiente para a sua apreciação e compreensão, tanto em relação ao contexto africano como também na compreensão da linguagem artística atual.

Com isso, a passagem pelas manifestações artísticas desses grupos étnicos e a aproximação com a arte moçambicana traz a realidade do país nos aspectos diretamente ligados ao oficio do artista, mas também o integra nos aspectos da dinâmica da sociedade.

Como atesta MORALEZ quando de sua estada no país: É uma cidade grande, com todos os problemas que Moçambique tem ${ }^{65}$. E estes problemas têm um passado, delineado brevemente em direção à compreensão da arte.

${ }^{65}$ MORALEZ, Rafael. Boiando em Moçambique, São Paulo: Balão, 2011, p.109. 


\subsection{A CENA ARTÍSTICA: "AS RAÍZES ANTES DAS FOLHAS"}

Faz-se necessário um breve comentário sobre a cena artística, pelo menos a dos 60 anos anteriores ao período escolhido, 2004 a 2010. Em Maputo, existem artistas já reconhecidos, inclusive internacionalmente, tais como Reinata Sadimba e Victor Sousa, para citar apenas dois deles, trabalhando com técnicas voltadas para a pintura, a escultura e o desenho.

Na reflexão sobre a arte contemporânea e a arte traduzida por estes mestres, uma reflexão em relação aos temas: atualmente estes também podem se repetir; e uma pergunta: mas então o que muda?

É com este confronto entre o tradicional, já aceito, e a produção atual, ainda em processo, que lidaremos no decurso deste trabalho. O que a arte contemporânea moçambicana traz de visualidade relacionada à sua própria cultura, elaborada ao longo de sua jornada histórica?

A maioria dos artistas renomados também continua na ativa; Victor Sousa, por exemplo, inaugurou exposição no Instituto Camões, em Maputo, em julho de 2011, sob curadoria de Jorge Dias. A necessidade de sua inserção no âmbito desta pesquisa considera a importância de uma vista de olhos, mesmo que inicial, do universo imagético que emerge do cenário moçambicano, e consequentemente a estranheza causada pela produção artística dos jovens artistas do Movimento de Arte Contemporânea de Moçambique, MUVART no seio da sociedade maputense.

Esta visualidade estará sendo construída ao longo do percurso deste grupo de artistas e poderemos notar afinal os pontos de convergência e as mudanças que, uma após a outra, as gerações normalmente trazem.

A expressão usada "As raízes antes das folhas" pertence a um comentário do artista Malangatana em relação a este grupo de jovens artistas, e é absorvida por nós como ação reflexiva.

A partir deste fato, consideramos as "raízes" a geração anterior, testemunhas atuantes do passado moçambicano e as "folhas" os jovens artistas, testemunhas do presente, assim como a arte contemporânea "em processo". 


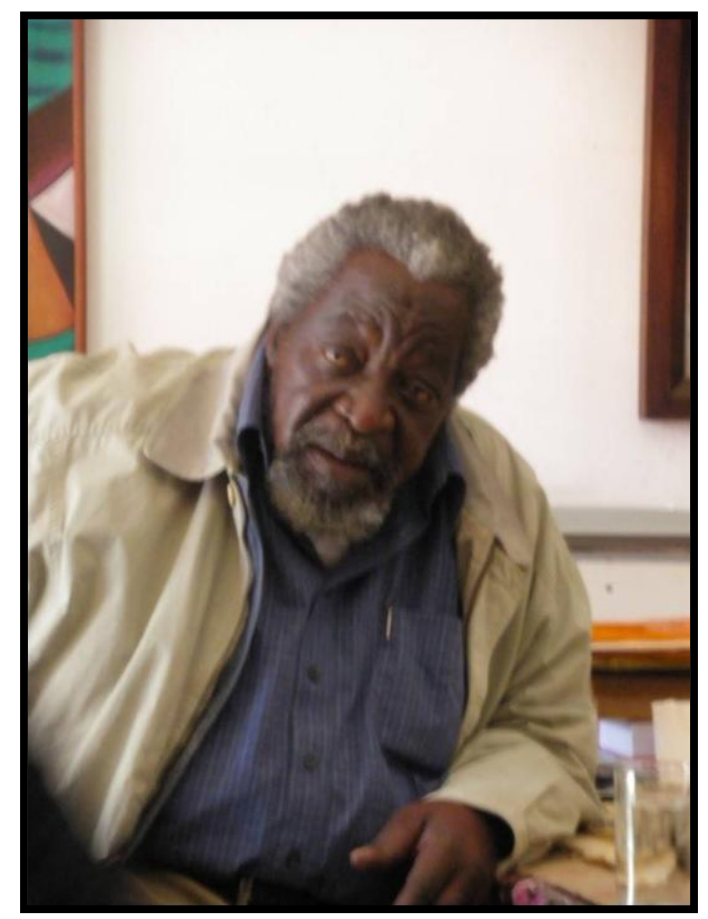

Figura 18

Malangatana Valente Ngwenya, 1936-2011

Malangatana era um artista autodidata. Foi, sem dúvida, um dos artistas moçambicanos de maior visibilidade no exterior. Falecido em 6 de janeiro de 2011.

Habituado a uma participação política dentro de Maputo, traz na sua arte engajada muitas questões ligadas à situação colonial e posteriormente à revolução. Após esse período, suas obras, pinturas, esculturas, desenhos e outras técnicas ganham temas mais universais.

Em julho de 2010, em entrevista concedida em Maputo, quando perguntado sobre o que achava da atual arte moçambicana e do grupo Movimento de Arte Contemporânea de Moçambique, MUVART, o pintor moçambicano mostrou-se descontente com o cenário artístico e, cético, observou que os jovens "não tinham raízes", e declarou que, na maturidade de seus então setenta e cinco anos, sentiase em momento ainda produtivo.

Homem de múltiplos talentos, navegava nas linguagens do desenho, aquarela, tapeçaria, cerâmica, gravura, escultura, entre outras manifestações, como está descrito em obra sobre o artista:

...Foi preso pela polícia política colonial, acusado de ligações à Frelimo, nos anos 60. Depois da independência (1975) participou em numerosas exposições colectivas dentro e fora do país... O seu nome está ligado à criação de várias instituições culturais tais como o Museu Nacional de Arte, 
Centro de Estudos Culturais, actual Escola Nacional de Artes Visuais e outras escolas artísticas. ${ }^{66}$

Malangatana vivenciou intensamente todas as fases importantes de Moçambique desde quando a capital ainda se chamava Lourenço Marques.

Para apresentar um painel resumido de cada artista aqui mencionado, optamos por mostrar o local de trabalho: o ateliê ${ }^{67}$ de Malangatana, de Reinata Sadimba e por último de Victor Sousa, uma vez que consideramos importante a organização dos materiais, ferramentas e métodos aplicados pelo artista no seu ambiente de criação (Figs. 19, 23 e 27).

Em seguida selecionamos os trabalhos de Malangatana, Reinata Sadimba e Victor Sousa que tivessem de alguma forma ressonância na produção dos artistas do Movimento de Arte Contemporânea de Moçambique, MUVART, sejam eles na grafia ou até mesmo na opção pela linguagem e materiais. É importante frisar que estes artistas fazem parte da educação visual por qual passou toda uma geração de jovens, na qual alguns seguiram na mesma profissão. Sendo muito extensa a produção destes três artistas, selecionamos alguns exemplos apenas para fazer uma intercessão entre a arte tradicional moçambicana e os jovens artistas do MUVART.

Em Malangatana é evidente a importância do desenho na construção de sua obra. Para realçar esta ideia temos dois exemplos de trabalhos: o primeiro deles Desenhos de prisão, 1969 (Fig. 20) é o resultado de sua estada na prisão, testemunho de sua participação política na vida moçambicana, e no último trabalho também denominado Desenho de prisão, 1969 (Fig. 21), com material mais denso, um trabalho atípico em sua trajetória. Ambos porém sugerem uma liberdade na grafia que propicia o distanciamento da linguagem realística, atrelada à escola clássica do desenho.

${ }^{66}$ COSTA, Alda, José, Benites, Lucas. (Org.) Percurso e Olhares: Uma introdução à Arte em Moçambique, EPM-CELP, Maputo, Moçambique, 2008, p.35.

67 Visitas ao ateliê de Malangatana em 2010, Reinata Sadimba e Victor Sousa em 2004. 


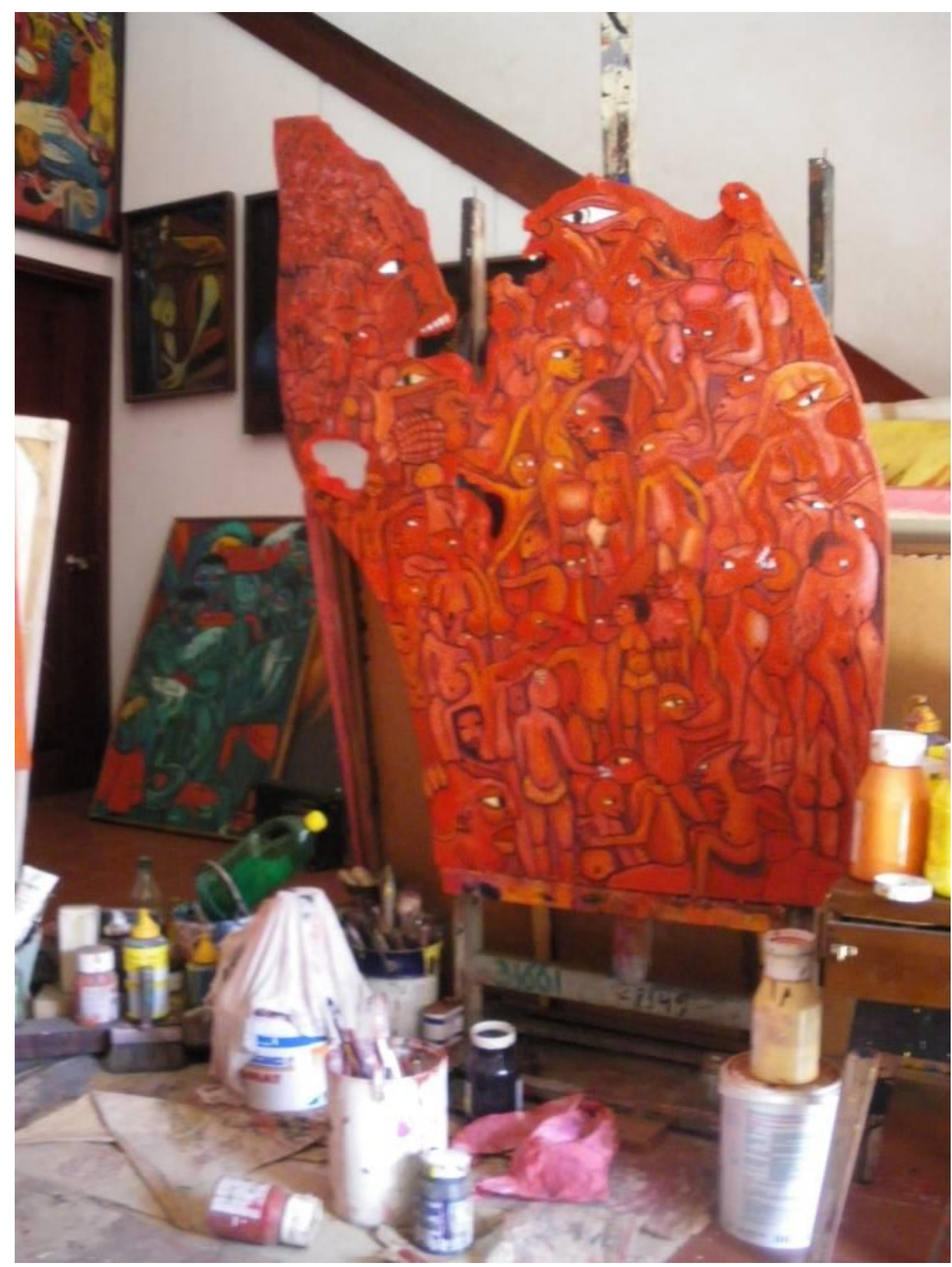

Figura 19

Ateliê de Malangatana 


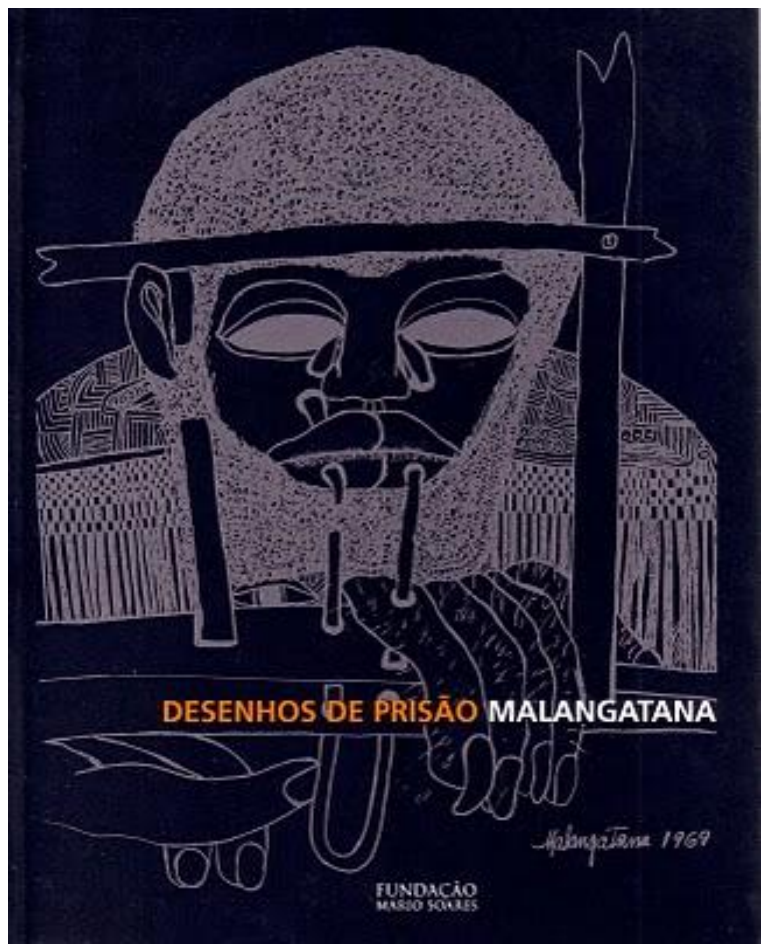

Figura 20

Desenhos de prisão, 1969

Figura 21

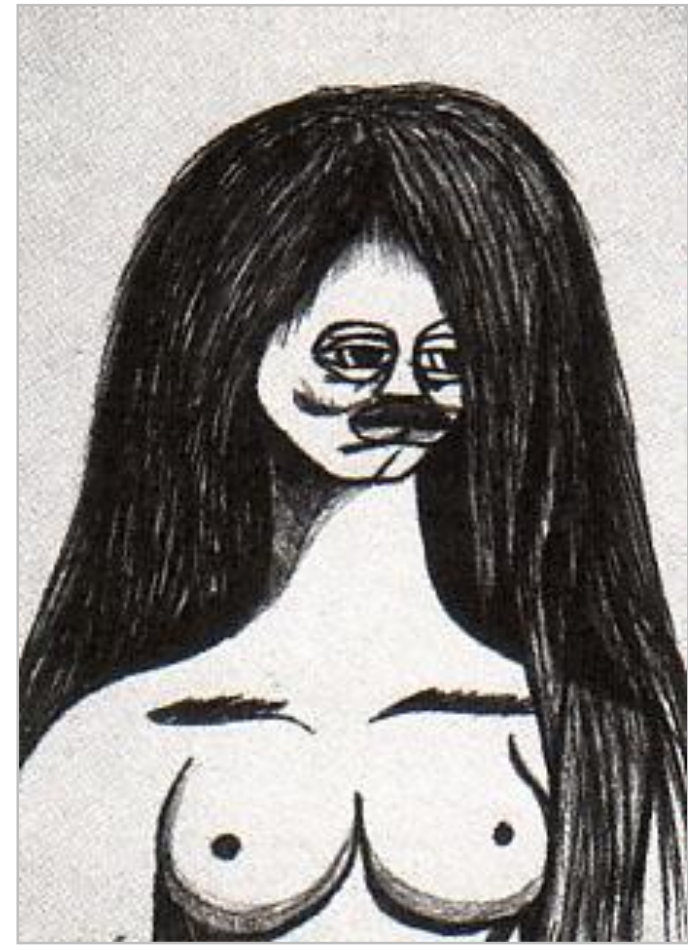

Desenhos de prisão, 1969 


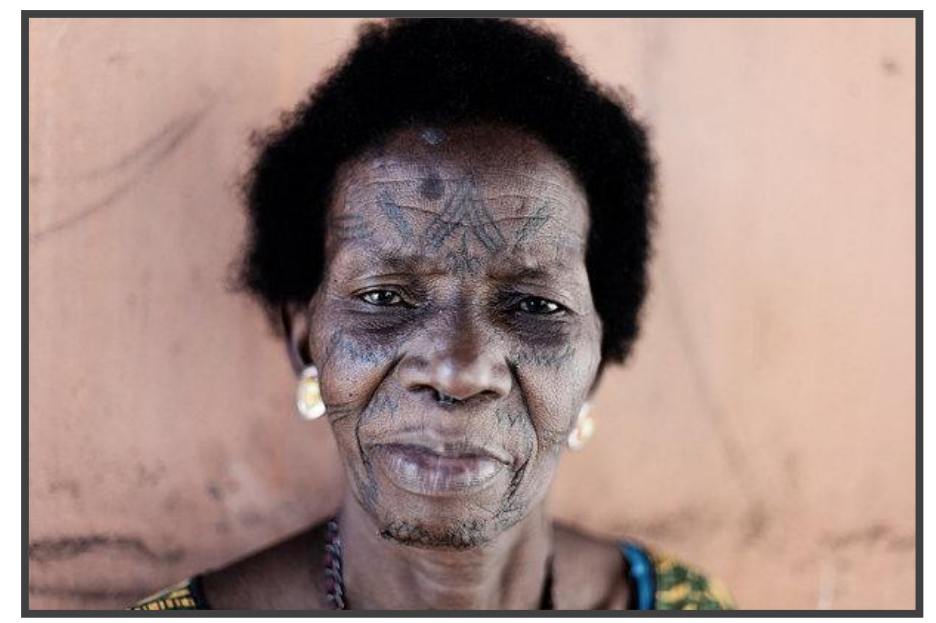

Figura 22

Reinata Sadimba, 1945

A artista Reinata Sadimba, nascida em 1945 na aldeia de Nimu, no planalto de Mueda, na província de Cabo Delgado, vive e trabalha em Maputo, Moçambique. Sobre a artista, no livro Percurso e Olhares, uma introdução à arte em Moçambique, comenta-se:

Filha de camponeses, recebeu a educação tradicional da etnia Makonde, e aprendeu a fazer objetos utilitários em barro, tal como as outras meninas e mulheres da comunidade. ${ }^{68}$

Porém, a artista maconde traz embutida na sua atitude uma necessidade de expressão que vai além das possibilidades utilitárias que suas peças teriam que abarcar inicialmente, como observamos na arte africana tradicional e especificamente relevantes para a sua comunidade. A olaria está muito presente na vida cotidiana dos macondes, seja na confecção de potes para carregar água, seja na de outras peças utilitárias.

Sobre esta região DIAS comenta;

Do alto do planalto de Mueda tem-se a impressão de dominar o mundo! As florestas estendem-se a perder de vista e ao longe erguem-se relevos que se confundem com brumas ou nuvens baixas. Aqui e além, no tempo seco, erguem-se penachos de fumo das queimadas ou dos incêndios. ${ }^{69}$

Reinata trabalha em cerâmica fora do grupo de sua comunidade; busca um repertório próprio. Suas peças revelam o universo maconde ao qual pertence. As

\footnotetext{
${ }^{68}$ COSTA, Alda, José, Benites, Lucas. (Org.), op. cit., p.51.

${ }^{69}$ DIAS, Jorge. vol. I, op. cit., p.23.
} 
escarificações estão presentes, porém, já permitem um olhar mais intimista sobre a gestualidade do dia a dia.

Com ateliê em Maputo, em um espaço cedido pelo Museu de História Natural, Reinata guarda grande quantidade de peças, e uma visita ao seu atelier é sempre a confirmação da sua grande e diversificada produção artística (Fig. 23).

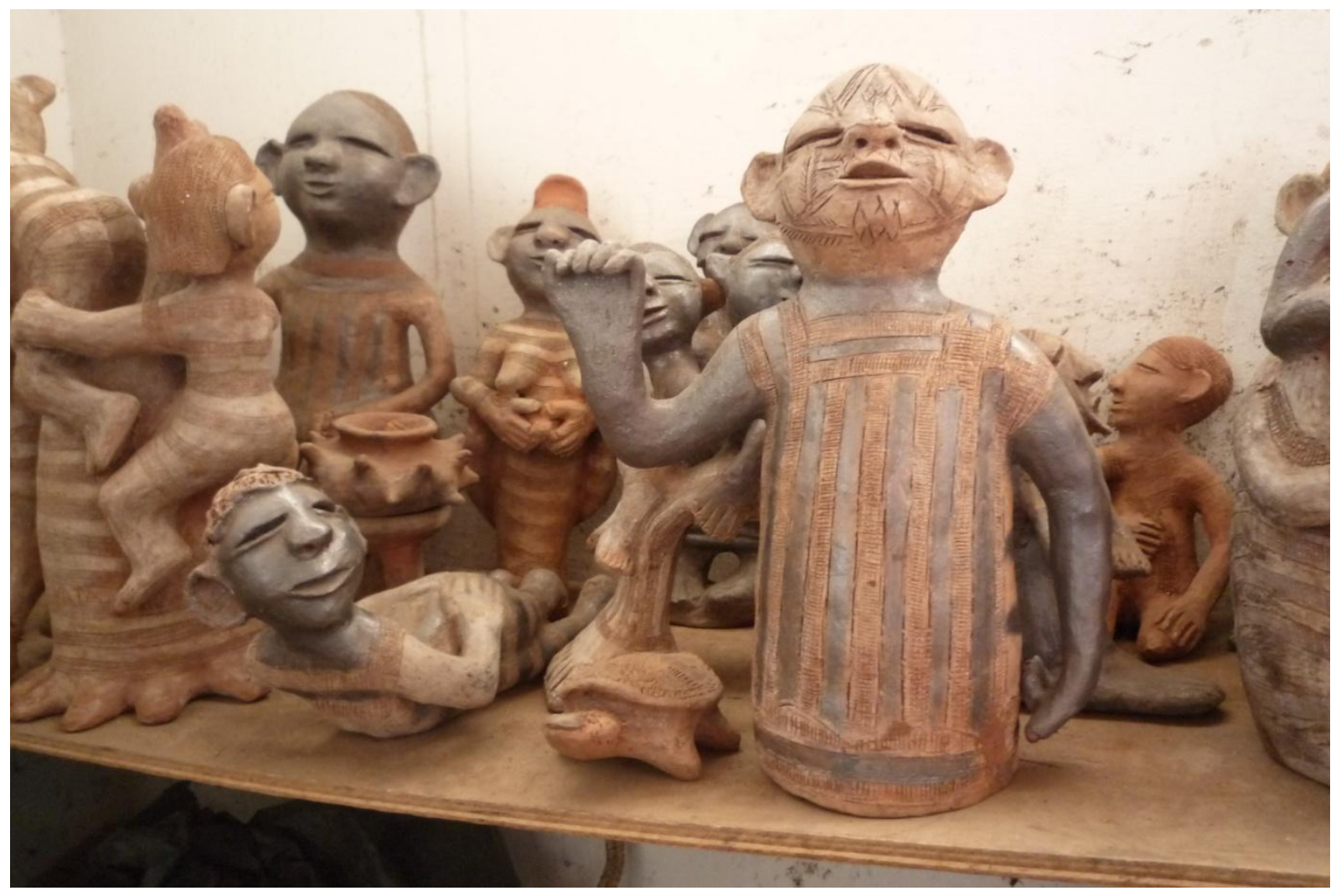

Figura 23 Ateliê de Reinata Sadimba

Na escultura Mulher Grávida, 2008, (Fig. 24), nota-se a representação de uma mulher grávida. Este tema é pouco recorrente na escultura, mesmo no Ocidente. Em geral a maternidade é representada com a figura da criança já nascida junto a sua mãe.

Na escultura A Colheita, 2007 (Fig. 25), encontramos a imagem da mãe e de seus filhos, o que também reporta aos hábitos do cotidiano de Maconde, pois a colheita faz parte das atividades relacionadas às mulheres, ficando a caça para os homens. A simbiose entre as imagens dá à peça um aspecto orgânico e dinâmico. 
Além do tratamento do tema, é interessante notar o material empregado: a argila e o grafite. Neste sentido, a permeabilidade e a elasticidade da argila permitem a liberdade na moldagem. Por outro lado, o grafite é mais duro, porém a artista tira partido da sua cor, percebendo-se o domínio e o conhecimento na manipulação do material. Este processo remete também às escarificações e tatuagens.

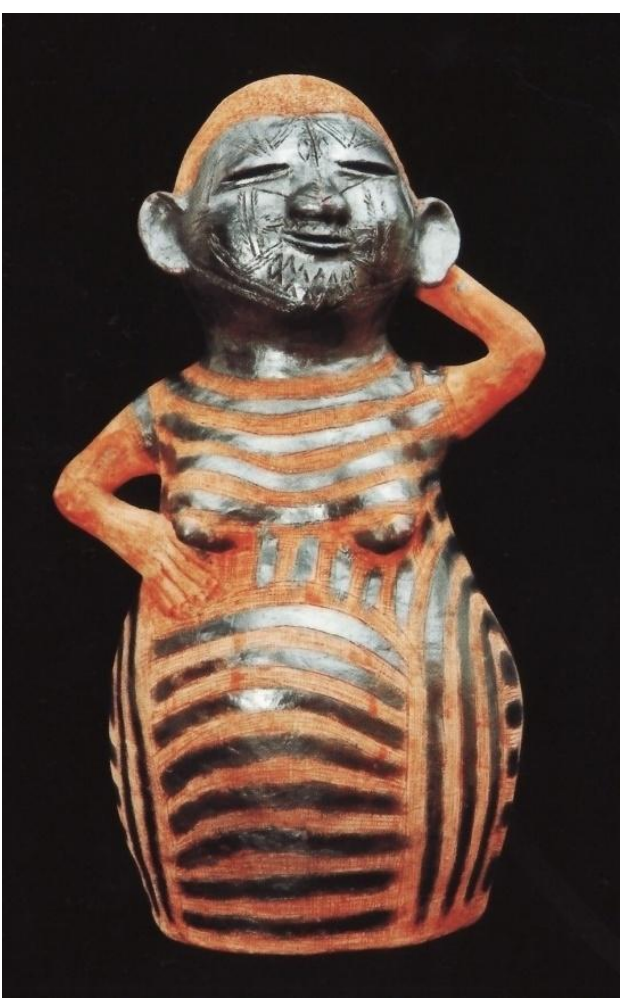

Figura 24

Reinata Sadimba

Mulher Grávida, cerâmica

$45 \times 22 \times 23 \mathrm{~cm}, 2008$

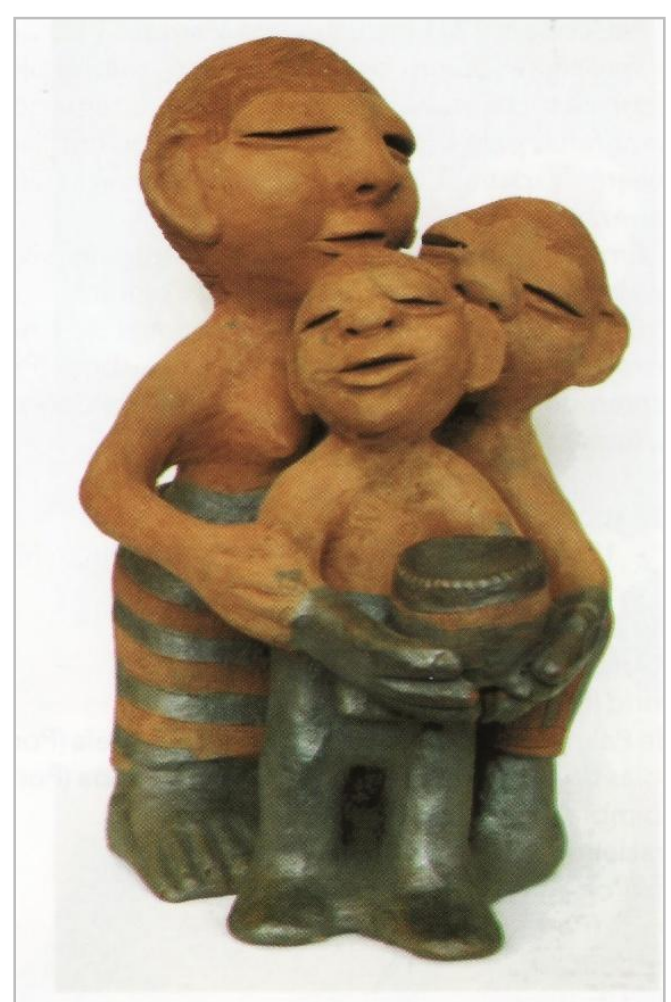

Figura 25

Reinata Sadimba

A Colheita, cerâmica

$18 \times 20 \times 25 \mathrm{~cm}, 2007$ 


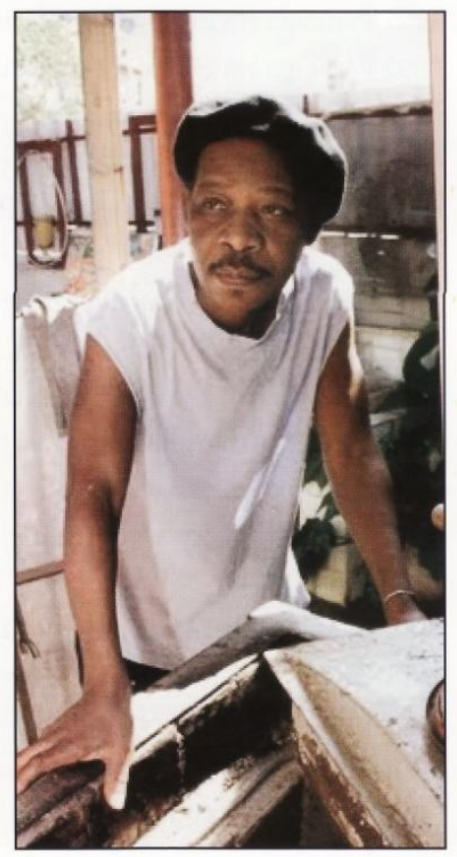

Figura 26

Victor Sousa, 1952

Victor Sousa nasceu em Maputo, em 1952, onde vive e trabalha. É o mais novo dos três artistas aqui apresentados. Com 59 anos é um trabalhador constante e próximo das novas gerações. Atua com disposição renovada nas exposições de arte contemporânea, sempre atento às novas possibilidades, arrisca-se trabalhando em outras linguagens como a instalação, sem romper com sua trajetória já consolidada na arte moçambicana, com a pintura e a cerâmica.

A seleção deste artista tem como um dos critérios o apoio que Victor vem dando à nova geração. Um exemplo desta postura foi a sua participação na primeira Expo-Arte Contemporânea, em 2004, bienal organizada pelo Movimento de Arte Contemporânea de Moçambique, MUVART, ocasião em que seu trabalho, uma escultura, foi capa do catálogo do evento, Acolhimento, 2004 (Fig. 29). Sobre esta exposição, o artista comenta:

Faço um trabalho sobre o espaço de proteção, de acolhimento, de repouso, de silêncio, de meditação...

Para mim, a pirâmide é uma forma de meditação, de ligação ao espiritual. O ninho é o lar, o sensível, que necessita de protecção. É um espaço que protege uma vida frágil. Com estes dois elementos estou a reflectir e a criar um espaço de repouso e outro de proteção e meditação.

O geométrico que envolve o orgânico, ou o racional que envolve o emotivo, ou a perfeição geométrica em cumplicidade com a perfeição orgânica. ${ }^{70}$

${ }^{70}$ Expo-Arte Contemporânea, Maputo, Moçambique, Catálogo da Mostra, 2004, p.39. 
Em visita ${ }^{71}$ ao ateliê do artista (Fig. 27), vê-se que este espaço de trabalho é sempre revelador do universo onde transita o artista e sua obra. Nele nota-se invariavelmente a profusão de imagens e materiais que habitam este espaço de criação, assim como nos demais ateliês visitados.

Na pintura O Regresso, 1991 (Fig.28), é possível notar o peso das figuras na construção das linhas de contorno e também na sua textura; observe-se como 0 artista usou esses recursos gráficos e a tinta para criar a percepção de volume.

Atuante na cena moçambicana, Victor Sousa foi também professor da Escola de Artes Visuais de Maputo (ENAV). Recentemente, foi lançado um livro biográfico sobre o artista, um importante documento da sua obra e do caminho que trilhou. Relembrando a atuação do artista, o diretor daquela Escola, Victor Sala, comenta:

Valendo-se da experiência acumulada na área de artes gráficas onde
trabalhou vários anos, tendo até recebido uma bolsa do SENAI do Brasil
para estudos nesta área profissional durante os quais Ihe foi atribuído o
prémio do desenho "10 de Maio" da mesma organização, Victor Sousa
tornou-se o $1^{\circ}$ professor moçambicano a leccionar na área específica, as
disciplinas de cerâmica e gravura.

Outro aspecto importante é o fato de que Victor Sousa também é membro honorário do Núcleo de Arte, por onde passou um expressivo número de artistas moçambicanos, incluindo o próprio Malangatana.

A atuação destes artistas, Malangatana, Reinata Sadimba e Victor Sousa é a ponte entre a arte moderna e a arte contemporânea. Através do trabalho desta geração, abre-se o caminho para novas linguagens e a construção paulatina de uma estética moçambicana. O registro das paisagens, das gentes, enfim da cultura do país é o legado destes mestres para as novas gerações, mesmo que nem sempre os temas escolhidos por estes artistas se refiram ao lado mais leve da vida.

É importante notar que os artistas continuam produzindo e se relacionando com as temáticas do seu tempo, o presente. Também são influenciadores e influenciados pelos jovens artistas, constituindo uma via de mão dupla.

\footnotetext{
${ }^{71}$ Primeira viagem a Moçambique realizada em jul.2004.

${ }^{72}$ SOUSA, Victor. O Sortilégio Estético de Victor Sousa, Alcance Editores, Maputo, 2010, p.13.
} 


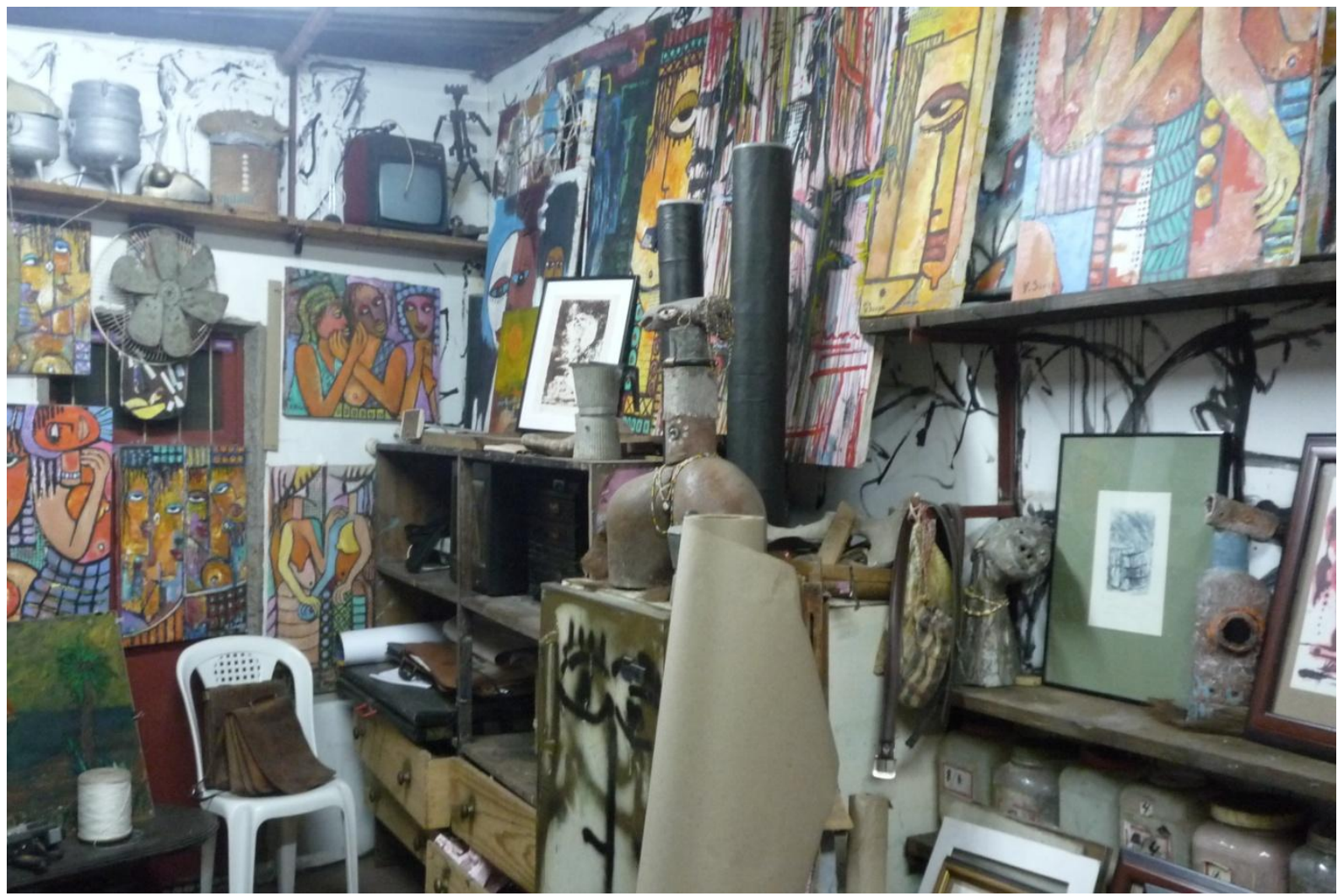

Figura 27

Ateliê de Victor Sousa

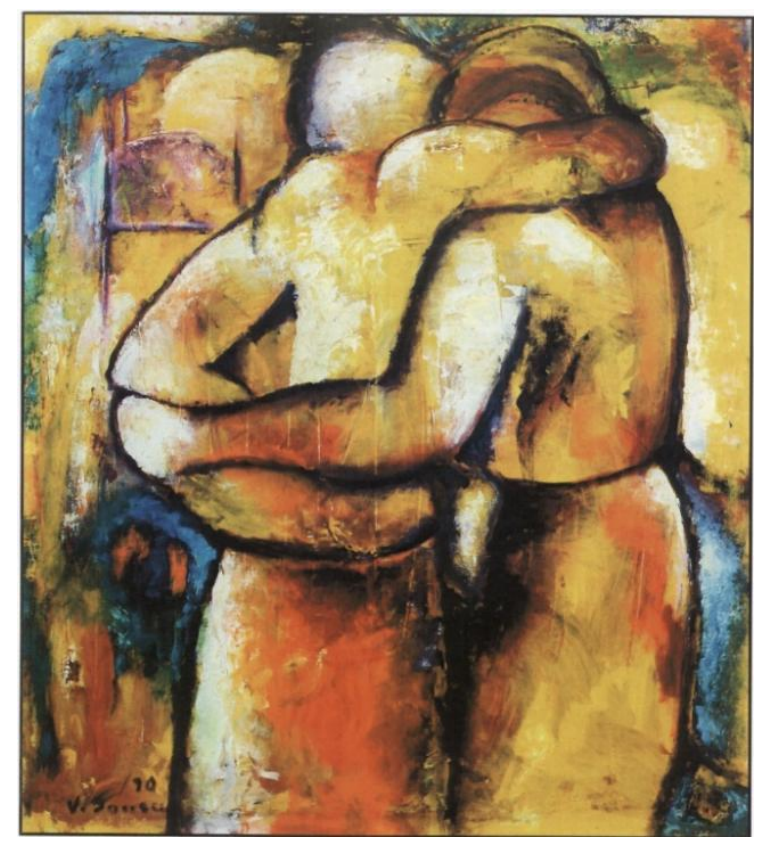

Figura 28 Pintura

O Regresso

1991

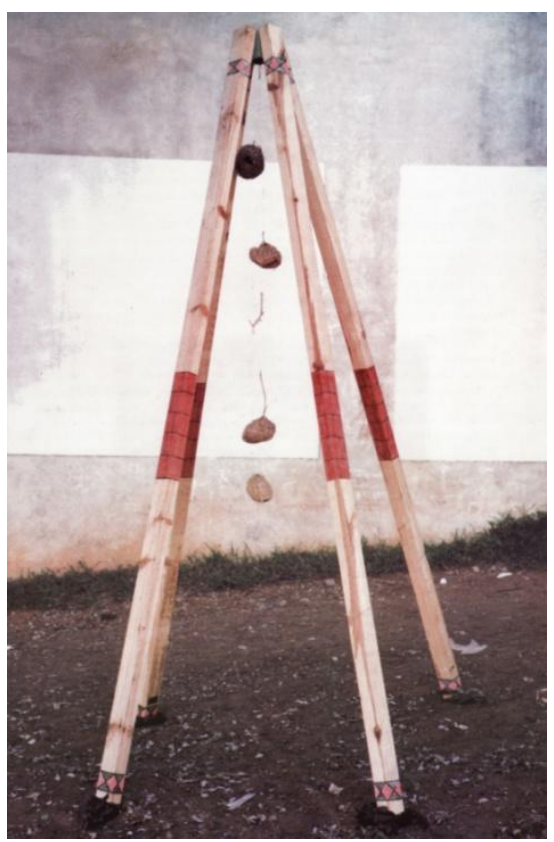

Figura 29 Escultura Acolhimento (detalhe) Madeira e ninhos

Dimensões variáveis, 2004 
Portanto, a relação dos artistas com a Arte Contemporânea é construída nesta sucessão de tentativas de convivência entre o passado e o presente, com a mobilidade pelo território, enriquecendo o repertório e a própria cultura de um país. Sobre esta realidade testemunha KI-ZERBO:

A troca cultural é muito mais desigual do que a troca dos bens materiais. Tudo o que é valor agregado é vetor de cultura. Quando utilizamos esses bens, entramos na cultura daquele que os produziu. Somos transformados pelo vestuário europeu que usamos, pelo cimento com o qual construímos as nossas casas, pelos computadores que recebemos. Tudo isso nos molda, enquanto nós estamos confinados a setores onde produzimos e ganhamos o menos possível, e a nossa cultura tem poucas possibilidades de se difundir, de participar da cultura mundial. É por isso que um dos grandes problemas da África é a luta pela troca cultural equitativa. Para isso, é necessário dar infra-estrutura às nossas culturas. Uma cultura sem base material e logística é apenas um vento que passa. ${ }^{73}$

É neste sentido que se percebe de que forma os artistas e a arte contemporânea irão inserir-se no âmbito internacional e no próprio mercado das artes visuais, principalmente no dos países emergentes.

Neste cenário, a arte moçambicana tem sua própria identidade, e carrega sua especificidade enquanto produção artística; com base na riqueza deste universo intrinsecamente complexo é que iremos apresentar as obras contemporâneas. Este universo artístico emergente traz também sua relação com o cosmo e com a sociedade na qual está inserido.

\footnotetext{
${ }^{73}$ KI-ZERBO, Joseph. Para quando a África? Entrevista com René Holenstein. Rio de Janeiro:Pallas, 2009, p.12.
} 
MAPUTO E A ARTE CONTEMPORÂNEA 


\section{MAPUTO E A ARTE CONTEMPORÂNEA}

Se os três artistas aqui selecionados, Malangatana, Reinata Sadimba e Victor Sousa, representam exemplarmente as raízes mais próximas da nova geração, em Maputo, capital de Moçambique, as distintas linguagens da arte contemporânea trazem ainda ao público estranhamento e ineditismo. A classe artística habituada às linguagens das belas-artes: desenho, gravura, pintura, cerâmica, escultura, tem contato, por meio dos integrantes do Movimento de Arte Contemporânea de Moçambique, MUVART, a outras linguagens até então desconhecidas de um determinado grupo de artistas e do público de modo geral. Esta hipótese é comprovada quando observamos as dificuldades de entendimento e apreciação desta produção; mesmo por parte de artistas experientes como o falecido Malangatana, a mídia também se interroga atônita: é arte? Por esta razão, a aproximação da arte contemporânea moçambicana necessariamente nos obriga a traçar linhas dentro de uma perspectiva histórica, abarcando distintos períodos como o colonial e o pós-colonial na África.

Voltamos a frisar que o "tempo histórico" do Ocidente não está diretamente em sintonia com o continente africano e, neste escopo, em consonância com Moçambique. Afetado por duas Grandes Guerras, e com políticas externas de expansão, no âmbito da arte, realçando a discussão proposta por NORDINE $^{74}$, destaca-se que, no Ocidente, a narrativa da escola modernista tem seu auge na década de 1920. Comprovadamente, a situação na África, no mesmo período, é completamente diferente; no século $\mathrm{XX}$, o continente africano ainda era colonizado por várias nações, como no caso de Moçambique por Portugal. As consequências desta política de colonização podem ser sentidas e apreciadas até o presente momento na sociedade moçambicana, por todo o território nacional e em diferentes países do cenário africano.

A respeito, DIAS complementa:

\footnotetext{
${ }^{74}$ NORDINE, Amin. "O que não é arte e que pode ser considerado como tal." Jornal Zambeze 19.ago.2010, p.31. Fonte: http://maimunaadam.wordpress.com/press/ acessado em 9 de novembro de 2010.
} 
A colonização européia de África fez-se acompanhar, de diferentes formas, da implementação de formas sociais e culturais ocidentais. Entre elas pode encontrar-se a integração no continente Africano das práticas artísticas e das normas estéticas das Belas-Artes (assim como posteriormente, do modernismo europeu). Pode assistir-se desde o colonialismo, a uma influencia muito forte das "escolas" de representação e expressão ocidentais na arte africana. ${ }^{75}$

A repercussão desta realidade narrada por DIAS é percebida e sinalizada hoje inclusive na imprensa local. Na reportagem do jornal Zambeze (Fig. 30), NORDINE declara:

...Ainda sobre a arte contemporânea, de nossa parte é de certo modo
perturbadora a sua conceitualização em Moçambique, tomando em conta
que o seu conhecimento é recente, para uma arte que foi bastante
divulgada nas décadas 60 e 70 . A nossa arte ainda segue a vanguarda
modernista... 76

Levando-se em conta que um dos aspectos da política da dominação é inibir a cultura local, no universo moçambicano este ingrediente foi essencial, e é o que dá respaldo ao comentarista. Este hiato temporal, mesmo considerando hoje a realidade global, deve ter em mente que a acessibilidade de informação continua atrelada aos aspectos socioeconômicos, e que ela permeia a realidade dos países considerados emergentes ou fora do eixo central do capitalismo, deixando à margem todos os demais países considerados hoje em tal posto. Voltamos a afirmar que esta situação não faz da África um continente sem história, como as nações que para lá acorreram e que pretendiam difundir suas visadas etnocêntricas.

Ao comentar a arte contemporânea no Benin e as dificuldades de aquisição e acesso de materiais artísticos tais como, telas, tintas, pincéis entre outros, JOLLY acaba por nos dar uma visão sobre a arte que abrange todo o continente. Encontramos neste relato um paralelo com a realidade moçambicana, em que as mesmas dificuldades são percebidas, como de encontrar os materiais necessários para a execução do trabalho e até mesmo a literatura na área.

\footnotetext{
${ }^{75}$ DIAS, Inês. DIAS POR AQUI. Op. cit., p.47. "As diferentes políticas coloniais são determinantes para perceber as diferentes presenças das Belas-Artes nos contextos africanos colonizados. A adopção pelo colonizado das Belas-Artes dá-se, em geral, em fase tardia do colonialismo, seguindo quer o modelo de imposição ocidental das suas formas de representação, quer o modelo da sua adopção pelo colonizado, possibilitada pelo contacto duradouro com o colono."

${ }^{76}$ NORDINE, Amin. "O que não é arte e que pode ser considerado como tal", Jornal Zambeze 19.ago.2010, p.31.
} 
JOLLY observa:

... "seria reducionista qualificar a arte contemporânea na África apenas de arte da recuperação. Os objetos recuperados são transcendidos e adquirem, através do artista, o estatuto de obras de arte alimentadas pela cultura do país onde se originam. Deve-se, de fato, parar de falar de "a cultura africana", de "arte africana", como se esse continente tivesse um único rosto. Ao contrário, ele é provavelmente aquele em que há maior diversidade de culturas. Culturas e seu corolário: as tradições. Tradições que, diferentemente daquelas dos países ocidentais, não são vividas como folclores, ou seja, essas manifestações antiquadas para turistas provincianos nostálgicos. Elas subjazem aos comportamentos, impregnam de espiritualidade os gestos e, em particular, o gesto criador do artista. ${ }^{77}$

Os materiais artísticos e as linguagens elegidas pelos artistas são elementos que juntos serão contidos na poética de cada um deles, que de forma diferenciada irão expressá-la. Neste sentido pode-se observar que este fator não é inibidor da qualidade da obra, nem na África e nem em qualquer outro lugar.

O testemunho de JOLLY trata da arte contemporânea, da produção atual, porém essa discussão sobre a compreensão da própria arte também se dava na arte moderna. No prefácio do seu livro publicado em 1988 STANGOS comenta:

"...Os ensaios, especialmente escritos para esta coletânea, têm o propósito de contribuir para uma historia da arte moderna. O pressuposto básico ao tratar $\mathrm{o}$ assunto à maneira de uma colagem é ser ainda prematuro para um só autor tentar um apanhado histórico e crítico coeso desse período, uma vez que ainda estamos vivendo nele..." ${ }^{78}$

Assim, é compreensível que em Moçambique a arte moderna tenha este lugar de apreciação junto à intelectualidade local, e por outro lado a arte contemporânea, realizada hoje, com o distanciamento destes códigos formais estabelecidos na arte moderna, tenha dificuldades de aceitação e compreensão, sendo recente a própria nominação para a arte contemporânea.

Segue ainda o autor:

Aquilo a que se chamou genericamente arte moderna, refletindo outras atitudes análogas na sociedade, tornou-se uma força libertadora explosiva

\footnotetext{
77 JOLLY, André. "A arte contemporânea e o Benin" In: África, Núcleo Interdisciplinar do Imaginário e Memória - NIME, Laboratório de Estudos do Imaginário, LABI, Instituto de Psicologia da Universidade de São Paulo, IP-USP, Ano X, nº 10, 2004/2005, p.138.

${ }^{78}$ STANGOS, Nikos, Conceitos da arte moderna, Rio de Janeiro: Jorge Zahar, 2000, p.7.
} 
no início do século, contra a opressão de pressupostos com freqüência cegamente aceitos até então. ${ }^{79}$

Entendamos que a perplexidade em relação à arte contemporânea também ocorre no Ocidente. Em análise contundente, CAUQUELIN põe em perspectiva a arte contemporânea e a arte moderna, no sentido da dificuldade de entendimento do público sobre a visualidade artística:

Infelizmente não se trata, no caso, de arte contemporânea no sentido estrito do termo - a arte do agora, a arte que se manifesta no mesmo momento e no momento mesmo em que o público a observa. Tão - somente se trata de arte 'moderna', se entendermos por moderno o século XX em geral. ${ }^{80}$

Isto posto surge em Moçambique o projeto da criação de um Museu. É importante notar que o país é um dos poucos no continente africano que possui este equipamento público. A salvaguarda desta memória cultural, discutida e construída por meio de representantes dos diversos setores culturais moçambicanos, foi responsável, a partir de 1989, pela institucionalização do Museu Nacional de Arte, em Maputo, que tem como um dos seus objetivos resguardar a produção artística moçambicana, adequando salas para a exposição de acervo permanente. Vemos que quatorze anos após a independência do País, a cidade ganha seu primeiro Museu institucional e público. Foi assim implementada esta etapa de institucionalização de um espaço para a arte: o museu como espaço adequado arquitetonicamente para exercer essa função. Um passo à frente é a transição da modernidade para a contemporaneidade, foco principal dos articuladores do Movimento de Arte Contemporânea de Moçambique, MUVART.

Estas profundas transformações sociais irão balizar a própria cultura moçambicana e criar um estranhamento sobre sua produção atual. É importante ressaltar o papel que o Museu Nacional de Arte, MUSART, irá promover a partir de sua instituição, a possibilidade de uma referência para a constituição de uma identidade moçambicana que irá afirmar-se após décadas de enfrentamento junto ao colonizador europeu.

\footnotetext{
${ }^{79}$ Op. cit., p.7.

${ }^{80}$ CAUQUELIN. Anne. Arte Contemporânea. Martins Fontes: São Paulo, 2005, p.11.
} 
Como testemunha da importância da institucionalização de um Museu Nacional, COSTA afirma que tal projeto gerou expectativas e controvérsias que demonstram mais um exercício de conciliação e diálogo entre os distintos setores da sociedade no sentido de atingir o seu fim:

Constituir uma coleção e abrir o museu ao público com uma exposição permanente de arte que "representasse" Moçambique independente não foi fácil. Como conciliar a vontade de expressão e afirmação cultural de um país recentemente libertado com a reflexão necessária sobre o passado da colonização e sobre a relação entre a Europa e África que se estabelecera e desenvolvera? ${ }^{81}$

A ampla discussão que envolveu diversos setores moçambicanos quando da instituição de um Museu Nacional traz à baila, novamente, a identidade moçambicana, difícil de definir após o longo período de intricada e conturbada relação com a identidade lusitana, como atesta DIAS na citação anterior. Este é um dos aspectos a serem resolvidos pela sociedade moçambicana; ou seja, os artistas estarão comprometidos com a afirmação de uma alteridade ${ }^{82}$, em relação dialética a identidade, pois ao contrário dos ideais do lluminismo trata-se no momento de salientar a diversidade em oposição à igualdade. Sobre esta alteridade não seria exagero declarar que está conceitualmente dentro da própria modernidade e que irá avançando no que se convencionou denominar de pós-modernidade no âmbito da arte.

Em Maputo, antes da ascensão do Movimento de Arte Contemporânea de Moçambique, MUVART, podia-se arriscar que o cenário artístico estivesse mais identificado com a linguagem da modernidade, como testemunha o jornalista moçambicano NORDINE. Como sugerem CANÊDO e outros historiadores, vale relembrar que a independência só aconteceu neste país em 1975, quando os temas e mesmo a circulação das obras e dos artistas foram amplificados. Dentro dessa experiência e do momento histórico, muitos artistas moçambicanos começaram a

${ }^{81}$ COSTA, Alda. Arte e Museus em Moçambique - Entre a construção da nação e o mundo sem fronteiras. Tese de Doutoramento, Universidade de Lisboa, Portugal, 2005, p.45.

82 MARCUSE, Herbet, Eros e Civilização. Uma Interpretação filosófica do Pensamento de Freud. Rio de Janeiro: Zahar Editores, 1978, apud p.41. "Freud descreve o desenvolvimento da repressão na estrutura instintiva do individuo. A luta pelo destino da liberdade e felicidade humanas é travada e decidida na luta dos instintos - literalmente, uma luta de vida e morte - em que o soma e psique, a natureza e a civilização participam...." 
participar ativamente nos acontecimentos políticos do país, tais como Malangatana e Reinata Sadimba.

Estes artistas da geração precedente, Malangatana, Reinata Sadimba e Victor Sousa, só para citar alguns, tinham formação autodidata ou experiência dentro da sua comunidade e na inserção em cursos profissionais que perpassam a área artística. Enquanto isso, a modernidade no Ocidente é representada principalmente pelos movimentos estilísticos e suas escolas, sendo bastante distintos os contextos ideológicos entre o moderno e o contemporâneo. A modernidade nasce nas sociedades européias e americanas após a I Grande Guerra Mundial; há uma total mobilização de uma construção física e espiritual, com a proposta de repensar a sociedade e seus valores.

Porém, entre o auge do modernismo e da II Grande Guerra (1939-1945), Moçambique ainda se encontrava sob o jugo colonial português e grande parte do seu território e do continente ainda eram desconhecidos no exterior. Observe-se que a missão de estudos de DIAS $^{83}$ ocorre em 1957, e o autor confessa que os Macondes constituem um grupo do qual se tem pouca informação fora do âmbito de sua própria comunidade; a maioria não falava português e sim banto, como é o caso atual da artista Reinata Sadimba. O próprio Malangatana tinha apenas 21 anos naquela ocasião e, no ano seguinte, em 1958, começa a frequentar o Núcleo de Arte $^{84}$, por onde passaram muitos outros artistas moçambicanos, além dos aqui comentados.

Os artistas moçambicanos irão trazer uma visualidade carregada de um sentimento de nacionalismo profundo. A geração seguinte, entre as décadas de 1960 e 1970, está comprometida com a revolução. Usaremos novamente Malangatana como exemplo de atuação: por conta da prisão de Nelson Mandela em 1964, o artista desiste de expor na África do Sul.

A esse respeito, afirma COSTA;

O artista era, pois, visto como um mensageiro de um discurso político ou social. Se algumas mudanças começaram a acontecer, a partir daí, nos vários países africanos já independentes, em Moçambique recém-

\footnotetext{
${ }^{83}$ DIAS, Jorge. Op.cit., vol. I, p.7.

${ }^{84}$ O Núcleo de Arte foi construído em 1921.
} 
independente pedia-se aos artistas que fossem construtores de uma arte nova. ${ }^{85}$

O rompimento fundamental com o etnocentrismo ocidental e a construção da visualidade da arte moçambicana são propiciados na geração dos três artistas, Malangatana, Reinata Sadimba e Victor Sousa. Seus trabalhos têm maior poder de circulação, uma vez que já não estão intimamente ligados à produção cultural de um grupo, como no caso dos Macondes, Macuas, Tsongas e Nyungwes, assumindo agora uma voz definida na qualidade de narradores e contestadores do sistema vigente por meio das suas obras.

Os artistas e a arte são convocados a dar sua contribuição nesta passagem do tradicional para o moderno. Em seguida outro desafio se faz pertinente; a passagem do moderno para o contemporâneo. Nessa passagem, o período de 2004 a 2010 é emblemático e significativo na área das artes visuais em Maputo, através do grupo de artistas do Movimento de Arte Contemporânea de Moçambique, MUVART.

Em Maputo novas gerações de artistas emergem com a dinâmica que altera e constrói na sociedade novas realidades e novos homens. Este dinamismo que a contemporaneidade traz é foco de análise de distintos pesquisadores ao redor do mundo como, novamente, a provocadora CAUQUELIN nos interroga:

Podemos nos perguntar se a arte não contemporânea - a do século XIX e
do principio do século XX - tinha qualidades tão fantásticas do ponto de
vista da inovação, do status econômico e do reconhecimento do público, a
ponto de parecer oportuno, até mesmo necessário, colocá-lo sobre um
pedestal e chorar seu desaparecimento. ${ }^{86}$

Para a autora, o avanço econômico e tecnológico mais uma vez desafia os homens e instiga os artistas, correspondendo a um amplo campo de possibilidades estéticas. A manipulação destas tecnologias anima todo o século $X X$ e avança no século XXI, no qual a fotografia e o vídeo assumem o papel de objetos portadores de arte e não apenas como ferramentas de auxílio à documentação etnográfica.

\footnotetext{
${ }^{85}$ COSTA, Alda. Arte e Museus em Moçambique - Entre a construção da nação e o mundo sem fronteiras. Op. cit., p.277.

${ }^{86}$ CAUQUELIN. Anne. Arte Contemporânea. Op. cit., 2005, p.17.
} 
Este sentimento de experimentação e de rompimento de matrizes já estabelecidas, ou narrativas, como credita DANTO, é uma das características do nosso século. Sobre o tema o autor reflete:

Em todo caso, a distinção entre o moderno e o contemporâneo não se fez clara até meados das décadas de 1970 e 1980. Por muito tempo a arte contemporânea continuaria a ser "a arte moderna produzida por nossos contemporâneos". A certa altura ficou claro que não mais se tinha um modo satisfatório de pensar, como ficou evidente pela necessidade de se inventar o termo "pós-moderno". Esse termo em si mesmo denunciava a relativa fraqueza do termo "contemporâneo" como passível de comunicar um estilo. Parecia-se muito mais a um termo meramente temporal. ${ }^{87}$

A análise anterior de CAUQUELIN nos dá a dimensão do avanço da própria noção e conceitualização da arte contemporânea; para DANTO, a dificuldade era sentida também na sua contextualização temporal.

As linguagens clássicas da arte - a pintura, a escultura e a gravura continuam inseridas no universo da contemporaneidade, apesar de manipularem suportes identificados com períodos anteriores, como DANTO comenta: "Hoje não há mais qualquer limite histórico. Tudo é permitido. Mas isso torna mais impositivo tentar compreender a transição histórica da arte moderna para a pós-histórica. ${ }^{, 88} \mathrm{~A}$ pista que identifica o ponto nevrálgico da apreciação atual da produção artística pode seguir esta trilha apontada pelo autor.

Neste aspecto, mais precisamente no século XX, os artistas do Movimento de Arte Contemporânea de Moçambique, MUVART, encontravam-se na sua maioria na adolescência, porém imersos em um ambiente completamente diferenciado culturalmente e politicamente em relação aos seus precursores Malangantana, Reinata Sadimba e Victor Sousa, entre outros do mesmo período.

Acompanhei a trajetória e a história de vida de cada um dos artistas do Movimento de Arte Contemporânea de Moçambique, MUVART, de acesso à informação, a outras visualidades artísticas, e ao processo de continuidade da formação educacional realizada em outros países, uma vez que não havia, naquele momento, centros de formação no nível de ensino superior na área de artes no

\footnotetext{
${ }^{87}$ DANTO, Arthur C. Após o fim da Arte: A Arte Contemporânea e os Limites da História. São Paulo: Odysseus Editora, 2006, p.14.

${ }^{88}$ DANTO, Arthur C. Op. cit., p.15.
} 
território nacional. O cenário é propício para a afirmação de outras propostas artísticas diferenciadas das exibidas na cidade de Maputo até então, sendo este o desafio proposto por este grupo de artistas. Os artistas do Movimento de Arte Contemporânea de Moçambique, MUVART, ao animarem o cenário artístico com as novas proposições, novamente encontram apoio do setor intelectual do país que, durante todo 0 processo de independência, foi construindo uma cultura moçambicana que os distanciasse das tentativas colonialistas do apagamento da cultura nacional. Como resultado desse apoio, esse citado setor intelectual percebe a possibilidade de sua própria inserção no âmbito global, alterando, consequentemente, a percepção da cultura local.

\section{0 que não é arte e que pode ser considerado como tal}

No sábado passado, os palestrantes foram a brasileira Vera de Albuquerque e a moçambicana Maimuna Adam.

Estas artistas deram a oportunidade para perceoportunidade para percena arte do video.

Vera Albuquerque fez Vera Albuquerque fez saber como é que esta arte se desenvolve no Brasil. Trouxe um video $\mathrm{cm}$ que demonstra o quanto um cubo da sua autoria suscitou curiosidade. Da ideia referiu que era criar a imagem de um museu num espaço público.

Questionou sobre se era possível criar uma arte pública. Tendo se avaliado que era, todavia depen que era, lodavia dependeninistrativas:

A Fiera, questionamos sobre a ambiguidade que surge da arte contemporainea, tomando $\mathrm{em}$ conta que certos inferem afimar que o que năo é arte pode ser considerado arte. determinado objecto mot-

Tivemos a ocasião de no passado fim-de- semana estarmos presente numa palestra por ocasião da Bienal de arte contemporânea "Roturas e desconversão" que decorre no Museu Nacional de Arte, em que participam também artistas estrangeiros.
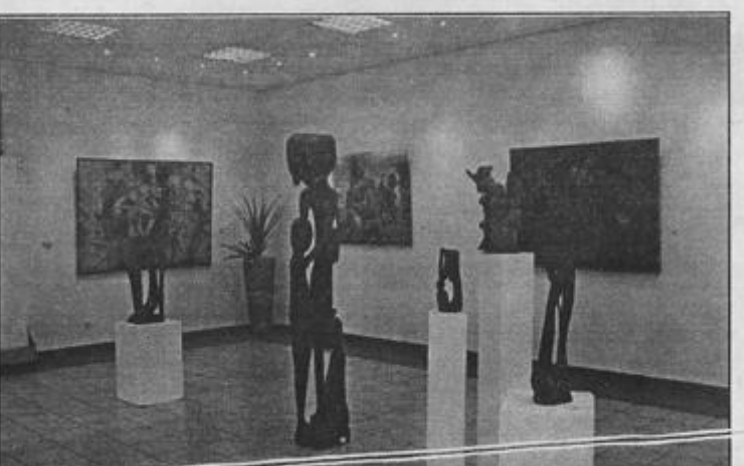

que em arte contemporânca eve se ter em conta $\mathrm{re}$ - uma certa contrariedade flexōes do ponto de vista de entre a arte e não arte, mas emocōes egocintricas. mesmo assim é possivel Cocoes egocentricas.

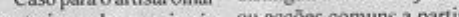
o cxterior vilgar ao inves ouchós com na de se apreender um assumto de até identificar-se com a paraclassifcaredistinguir a arte de qualquer outro Ainda sobre a arte con- objecto.

temporânca, de nossa parte Eadianta que devia hav. e de certo modo perturba- er discussto sobre o assundora a sua conceitualização to. Nấo sendo necessário, em Moçambique, tomando julgamos que a arte tem os em conta que o seu con- seus padróes.

hecimento é recente, para Essa de que o visionuma arte que foi bastante ável por bishilhotica fi:le din...

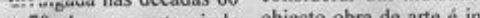
e 70. A nossa arte ainda objecto obra de arte ce insegue a vanguarda mod- trigante. O belo contemporâneo querque se referiu que não busca o novo, nem o o facto de se ter tapado espanto, propóe o estra- estátuas com plástico en nhamento, as formas dos plena via pública da cidade objectos tornam-se quase de $\mathrm{S}$. Paulo e os transeuntes

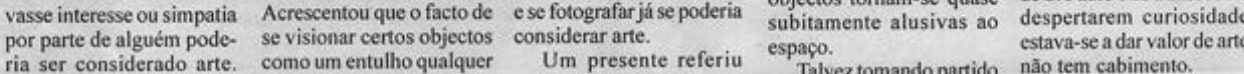
$\begin{array}{llll}\text { vasse interesse ou simpatia } & \text { Acrescentou que o facto de e e fotografarjá se poderia } & \text { subitamente alusivas ao despertarem curiosidade } \\ \text { por parte de alguém pode- } & \text { se visionar certos objectos } & \text { considerar arte. } & \text { estava-se a dar valor de arte } \\ \text { ria ser considerado arte. } & \text { como um entulho qualquer } & \text { Um presente referiu espaço. } & \text { Talvez tomando partido não tem cabimento. }\end{array}$

Figura 30

NORDINE, Amin. O que não é arte e que pode ser considerado como tal. 
Em 2011, quando completou trinta e seis anos de sua Independência, Moçambique é um país em plena reconstrução, atravessado por constantes crises de ordem socioeconômica; esta realidade, porém, convive como força motivadora para estes jovens artistas do Movimento de Arte Contemporânea de Moçambique, MUVART. 


\subsection{OS FILHOS DA REVOLUÇÃO: ARTISTAS}

A prática artística do século XX mostra os efeitos da Revolução Industrial, 0 acesso aos novos materiais e a discussão da entrada no novo século, consequências e rupturas. Esta ruptura marca o choque do que passa a ser definido como tradicional e o seu limite para o contemporâneo.

Citando a geração de Malangatana, Reinata Sadimba e Victor Sousa, "as raízes", como contraponto aos artistas do Movimento de Arte Contemporânea de Moçambique, MUVART, "as folhas", reiteram-se aspectos da discussão anterior, ou seja, quais os limites entre a tradição e a contemporaneidade? E como os jovens artistas se posicionam neste sentido.

Os artistas escolhidos para exemplificar estas características são nomes cujos trabalhos delineiam aspectos relacionados ao contexto em que estão inseridos e também a aspectos mais sutis, relacionados a poéticas trazidas dos contextos e vivências pessoais. No geral, estas poéticas são construídas e impregnadas de materiais locais que trazem uma discussão mais ampla, e também questionamentos da arte e do papel do artista na sociedade contemporânea. A realidade social do papel da mulher, da religião, da sociedade e da economia também é exposta. Mas existem, além destas, outras chaves para a compreensão da arte realizada hoje, independentemente de sua localidade.

Apontando ainda para a materialidade da arte contemporânea, TRIGO chama a atenção para novas regras do jogo:

$\mathrm{Na}$ passagem do moderno ao contemporâneo, as relações entre os diferentes atores do sistema da arte mudaram. No passado os marchands se perguntavam, diante de um artista novo: sua obra tem valor artístico? Resistirá ao tempo? Traz algo de novo à historia da arte? Hoje o foco passou da obra ao artista, e as perguntas passaram a ser: sua atitude se enquadra nas regras do circuito institucional/internacional? Ele terá uma relação adequada com os agentes do sistema? Seu valor dependerá dessas variáveis, e não de fatores convencionais como originalidade, valor estético ou histórico. ${ }^{89}$

${ }^{89}$ TRIGO, Luciano. A grande feira - Uma reação ao vale-tudo na arte contemporânea. Civilização Brasileira: Rio de Janeiro, 2009, p.64-65. 
Para TRIGO é fundamental ter em vista as bases em que estamos construindo a arte hoje e de que forma ela será incluída, ou não, na própria história da arte como o retrato do que somos da expressividade do nosso tempo.

Nesta perspectiva posta em relevo por TRIGO surge o papel da crítica como agente formador de opinião. Sobre este tema BATTCOCK comenta, analisando o cenário americano: "Nos dias de hoje a crítica está em vias de se tornar quase tão essencial ao desenvolvimento - aliás, à identificação - da Arte, como o próprio artista." ${ }^{90}$ E segue sua análise:

O crítico moderno não se contenta mais com a simples descrição usada como uma base para juízos de valor, ou mesmo com os processos mais sofisticados de definição artística. Foi o artista que o forçou a mudar de terreno. Atualmente é a idéia que predomina - o interesse do artista transferiu-se de valores exclusivamente pictóricos para considerações sobre as extensões do meio. É isto que constitui essencialmente o novo modo de encarar a secular tarefa do artista de definir um relacionamento entre a Arte e a vida. ${ }^{91}$

A revolução cultural que varre o Ocidente é sentida no continente africano sob os auspícios das independências. Na década de 1960 na Europa DEBORD já antecipa o atual estado da arte, em seu livro $A$ sociedade do espetáculo comenta: "Toda a vida das sociedades nas quais reinam as modernas condições de produção se apresenta como uma imensa acumulação de espetáculos. Tudo o que era vivido diretamente tornou-se uma representação." 92

Após os comentários de TRIGO, BATTCOCK e DEBORD observa-se como os paradigmas se alteram constantemente e especificamente no século $X X$, e nesse sentido, tratando-se de uma produção que ainda está em processo, é também compreensível que esta "revolução" esteja em curso. Mais uma vez são os artistas os principais protagonistas. Trata-se de levar em consideração a dinâmica das sociedades, com os autores em foco pondo em relevo e enfatizando as mudanças que ocorrem desde o início do século $X X$, que abarcam tanto os setores da economia quanto o das alas culturais.

\footnotetext{
${ }^{90}$ BATTOCOCK, Gregory. A Nova Arte. São Paulo: Perspectiva, 2002, p.13.

91 Op. cit., p.14

${ }^{92}$ DEBORD, Guy. A sociedade do espetáculo. Rio de Janeiro: Contraponto, 1997, p.13.
} 
Circunscrever este cenário significaria também retomar a própria criação da Internacional Situacionista ${ }^{93}$ como agente de crítica da arte e da política, onde DEBORD é uma das vozes mais ativas, para PERNIOLA:

A primeira preocupação da Internacional Situacionista é aquela de romper de modo definitivo com o ecletismo cultural que é a cortina ideológica atrás da qual o mercado das obras de arte, articulado em vários racket, esconde interesses exclusivamente comerciais: os mercadores da arte, os críticos complacentes, os diretores de galerias...representam os peões, os pontos de sustento da ordem social dominante no âmbito da produção e da circulação de um tipo de mercadoria de luxo. ${ }^{94}$

A realidade africana é completamente diversa; a arte no continente não participa deste circuito identificado pela Internacional Situacionista, nem de qualquer dos demais movimentos do período. Neste momento poucos são os artistas africanos que transitam nos salões europeus e americanos - o que de fato ocorre até hoje - com algumas exceções, por exemplo os artistas africanos em diáspora. Enquanto neste período na Europa e EUA se discutia a sociedade de consumo os países africanos lutavam por sua independência. Portanto, trata-se de diferentes revoluções; é necessário este entendimento para que se usem réguas distintas. A arte moçambicana, mais conhecida pela pintura e pela escultura originalmente em madeira, apresentava algumas características da produção artística de Maputo, até então, em termos de linguagem e suporte. Evidentemente, esta produção artística é heterogênea por todo o continente africano e depende do grupo a que está ligada tradicionalmente. Daí a importância do entendimento dos valores imbricados nesses sistemas, que irão refletir-se posteriormente em todas as obras.

Os artistas fundadores do Movimento de Arte Contemporânea de Moçambique, MUVART exemplificam esta ruptura como Gemuce, Ivan Serra, Jorge Dias e Marcos Bonifácio "Mutheywue", para citar apenas alguns, pois elegem outras

\footnotetext{
${ }^{93}$ PERNIOLA, Mario. Os Situacionistas. O movimento que profetizou a "Sociedade do Espetáculo". São Paulo: Annablume, 2009, p.15. "...A consciência do caráter essencialmente revolucionário da arte, da poesia e da sua profunda tendência à auto-superação sobrevive de modo penoso e confuso no Surrealismo, no Letrismo, no grupo Cobra (1948-1951), no "Movimento por um Bauhaus Imaginista". Todas estas experiências estão na origem da Internacional Situacionista, a qual nasce em julho de 1957 em Coscio d'Arroscia (Cuneo)...".

${ }^{94}$ PERNIOLA, Mario. Op. cit., 2009, p.16.
} 
linguagens advindas de diferentes mídias tais como a instalação, a publicidade, o vídeo, a performance, entre outras.

Além das questões relativas às linguagens e suportes artísticos, uma outra pergunta freqüente: existe em Moçambique lugares para o artista expor seu trabalho? A resposta a esta pergunta levou-nos a mapear a cidade de Maputo; a pista inicial foi-nos dada pelos próprios artistas analisando a trajetória de cada um através do Curriculum Vitae. Posteriormente registramos e conferimos estes espaços quando da nossa estada na cidade. O resultado pode ser conferido no Anexo D, um roteiro, no qual se apresentam informações históricas, localizações, entre outras.

Descobrimos também que, apesar de existirem estes espaços formais de exposição artística, surgem outras possibilidades de mostras criadas pelos próprios artistas moçambicanos, como atesta Jorge Dias em artigo crítico sobre exposições que ocorriam na cidade:

\footnotetext{
... "Ainda não está em debate o espaço como lugar da arte, mas o espaço alternativo para receber a arte...Temos em ambos casos, as mesmas estratégias de utilização dos espaços alternativos para a circulação da arte. O espaço que recebe a obra da arte e que não é questionada como lugar da arte. Reinata Sadimba e Mapfara têm conteúdo para se apresentarem em qualquer outro espaço convencional. Pretendem questionar os espaços ou a procurar outras formas de aproximação de públicos que não se apresentam em lugares convencionais da arte?" 95
}

Nota-se que a contemporaneidade traz discussões que vão além das linguagens e dos suportes, entrando o espaço físico e psicológico como matéria interrogativa, promovendo no processo do fazer artístico um elemento importante que irá debater os aspectos estéticos e os possíveis valores morais inseridos no contexto da realidade, no caso específico, na sociedade moçambicana.

95 DIAS, Jorge, "Lugares da arte e Arte nos lugares", jornal O País, 01 outubro de 2010, Fonte: http://www.opais.co.mz/index.php/opiniao/134-jorge-dias/9912-lugares-da-arte-e-arte-noslugares.html, último acesso em 19 de março de 2011. 


\subsection{MOVIMENTO DE ARTE CONTEMPORÂNEA DE MOÇAMBIQUE, MUVART}

A cena artística de Maputo, em Moçambique, a partir de 2004, foi alterada pela presença de um grupo de jovens artistas que, reunidos, oficializaram a criação do Movimento de Arte Contemporânea de Moçambique, MUVART ${ }^{96}$. Para apresentar a inserção desta nova produção iremos abordar o período de 2004 até 2010, por meio principalmente do evento Expo-Arte Contemporânea, bienal organizada pelo grupo e acolhida desde então pelo Museu Nacional de Arte, MUSART $^{97}$.

O que é o MUVART? É o exercício de um grupo de artistas de trabalhar com a pluralidade de ideias, de materiais, de discursos e, principalmente, em uma África real, completamente distanciada do continente imaginado pelo colonizador e tão difundida nos mais diversos circuitos. Em "Txovando a Arte Contemporânea", COSTA salienta:

Em Moçambique, a procura de novos caminhos, envolvendo artistas com experiências pessoais diversas, que acontecia no início dos anos 90, principalmente em Maputo, desenvolveu-se em muitas direcções: o regresso de mais bolseiros ao país, desta vez bolseiros que já se tinham graduado na Escola de Artes Visuais local ${ }^{98}$, que tinham freqüentado escolas superiores de arte em diversos países e procuravam localmente 0 seu espaço, o surgimento de um numeroso grupo de jovens que se iniciava, seguindo os ensinamentos e os caminhos de um mestre já afirmado ou saídos da única escola de arte existente e a afirmação individual de artistas já conhecidos e pertencendo a diferentes gerações. ${ }^{99}$

É nesta perspectiva que se configura o espaço de ação dos artistas moçambicanos: a experiência adquirida em outros países, no caso dos bolseiros, exemplo especifico dos artistas do MUVART, o trabalho com colegas de outras nacionalidades e o intercâmbio advindo do contato com outras culturas como

\footnotetext{
${ }_{97}^{96}$ Ata lavrada em cartório em 24 de janeiro de 2004; vide anexo A.

97 Expo-Arte Contemporânea, Maputo, Moçambique, catálogo da mostra, 2004, p.3, apud ..."A Fortaleza de Maputo, o Centro Cultural Franco Moçambicano e o próprio Museu Nacional de Arte, foram os locais selecionados para levar avante os primeiros empreendimentos deste grupo..." .

${ }^{98}$ Ibid., p.6, apud "A Escola Nacional de Artes Visuais começou a funcionar em 1983. Antes de 1983 tinham existido no Centro de Estudos Culturais/CEC, entre outros, cursos de Educação Visual."

${ }^{99}$ Ibid., p.6.
} 
estudantes trouxeram no retorno a Maputo a vontade de criar espaços que refletissem essa condição adquirida e buscar interlocutores.

Num primeiro momento identificaremos onze artistas fundadores do Movimento de Arte Contemporânea de Moçambique, MUVART, a saber; Anésia Manjate, Carmen Muiaga, Gemuce, Ivan Serra, Jorge Dias, Lourenço Eugenio Cossa, Marcos Bonifacio, Mondlane, Quentin Lambert, Vania Lemos e Xavier Beve (Tabela 1). A maioria destes artistas inicia o seu percurso na Escola Nacional de Artes Visuais (ENAV), criada em 1983, em Maputo, onde hoje alguns deles são professores. Anteriormente, a escola era composta por docentes provenientes de Bulgária, Chile, Cuba, Holanda, Inglaterra, Itália, Polônia, Portugal e URSS. Finalizado o período inicial de formação, alguns desses artistas partem para: Alemanha, URSS, Portugal, Cuba e Brasil, na tentativa de dar prosseguimento aos estudos, agora em níveis de graduação e pós-graduação, possibilitando-lhes outros eixos de discussão da arte. Ao retornarem a Moçambique, unem-se e criam o Movimento de Arte Contempôranea de Moçambique - (MUVART), segundo o relato de Julieta Massimbe ${ }^{100}$; "O Muvart é a vontade e a concretização de uma nova forma de estar na arte" ${ }^{101}$ afirmativa que nos dá a ideia do alcance que esta empreitada significou no panorama das artes na sociedade moçambicana e o que ambicionava atingir com suas numerosas ações no contexto cultural de Maputo, incluindo palestras, exposições coletivas, workshops, e outras atividades culturais. Inicialmente formado por onze artistas, propõe parceria com o Museu Nacional de Arte, MUSART, e outras instituições locais, e em 2004 dá início ao seu projeto mais audacioso, ou seja, a realização de uma exposição com cerca de 37 artistas "provenientes dos diferentes quadrantes do globo"102, evento inserido nas comemorações do $29^{\circ}$ aniversário da independência de Moçambique. Para entendermos melhor a proposta e a dinâmica deste grupo de artistas, lançamos mão do manifesto do movimento, escrito em 2002:

... "o Muvart reivindica a capacidade dos artistas moçambicanos de participarem na arena internacional, não como um simples espelho de uma

\footnotetext{
${ }^{100}$ Diretora do Museu Nacional de Arte, Maputo, Moçambique, 2004.

101 Expo-Arte Contemporânea, Maputo, Moçambique, catálogo da mostra, 2004, p.3.

102 Ibid., 2004, p.3.
} 
África congelada dentro das suas tradições, mas como testemunho do mundo de hoje, a partir das riquezas humanas únicas. ${ }^{103}$

Imbuídos fortemente de objetivos em comum, o grupo visava à maior divulgação dos novos artistas e de sua produção. O debate propõe contextualizar a arte em sua fronteira libertária, voltada para as propostas estéticas dos próprios artistas e seus cânones.

Vivenciadores de uma sociedade em constante dinamismo, desde a sua formação, seu período colonial, até a construção e reconstrução do país, buscam a legitimação de seu papel de artistas, o diálogo com sua história, e seus aspectos ancestrais em consonância com uma África incluída no mundo contemporâneo. Neste sentido, sobre a atuação do MUVART, COSTA comenta:

A primeira exposição dos artistas do Movimento, realizada em 2003, suscitou interesse e curiosidade por parte do público que a visitou - uma nota positiva pois dele se espera uma relação com a obra de arte mais participativa - mas passou praticamente despercebida nos jornais ${ }^{104}$...Um ano depois, prosseguindo o seu interesse em chamar a atenção para a multiplicidade de meios que os artistas têm à sua disposição, para a experimentação criativa e para as práticas artísticas contemporâneas, organizam esta exposição para a qual convidaram artistas de Moçambique e de outros países. Que a exposição tenha lugar no Museu Nacional de Arte não deve passar sem reparo. Durante muito tempo olhado com desconfiança pelos artistas contemporâneos, o museu de arte e os artistas foram gradualmente encontrando formas de relacionamento. ${ }^{105}$

A ação do MUVART altera o cenário das artes em Maputo; os vários Manifestos $^{106}$ divulgados pelo grupo e as quatro Bienais de Arte Contemporânea (2004, 2006, 2008, 2010) consolidam este espaço conquistado. Este grupo de artistas tem uma formação inicial que se alterou ao longo do tempo. Já contados sete anos, considerando a contagem a partir de 2004 até 2011, cada um segue um caminho individual que entrelaça a arte, o estudo e a própria sobrevivência no sistema e no mercado da arte. Assim, relata-se a trajetória de cada um dentro deste período. Sobre o surgimento do grupo MUVART, COSTA testemunha:

\footnotetext{
103 Ibid., 2004, p.9

104 Ibid., 2004, p.8, apud "Francisco Manjate referiu-se à exposição algum tempo depois, Notícias (Cultura) de 5 de Maio de 2004."

105 Ibid., 2004, p.8.

106 "A arte em Moçambique precisa de se afirmar como instrumento fundamental e interveniente na sociedade. (...) É urgente alargar o número de apreciadores interessados pela arte, abrir novos horizontes em relação a novas formas de práticas artísticas e estender este esforço para além da cidade capital". Manifesto MUVART - 2003.
} 
Quando apresentei, no ano passado, a exposição de arte contemporânea que marcou o aparecimento público do Movimento de Arte Contemporânea de Moçambique constituído por um grupo de jovens artistas, considerei esse acontecimento como um sinal de mudança e de crescimento mas também reflexo da multiplicidade de práticas artísticas em Moçambique. Entendi esta e outras acções do Movimento com um desafio corajoso e provocador num contexto artístico que, apesar de reflectir vitalidade e diversidade, tem pouca exposição à prática e à apreciação da arte contemporânea e olha, às vezes, com desconfiança, a diferença, o que "vem de fora", "outras" práticas e realidades artísticas. ${ }^{107}$

O testemunho de COSTA reflete o cenário artístico e a apreciação da arte em Moçambique. Com a criação do Museu Nacional de Arte, MUSART inicia-se um processo de formação de público essencial na constituição e preservação do patrimônio cultural e o consequente apoio a novas formas de expressividade.

Importante acrescentar que o Movimento de Arte Contemporânea de Moçambique, MUVART, foi registrado em cartório (ver Anexo A), o documento expressa a denominação do grupo, lê-se:

A Associação Movimento de Arte Contemporânea de Moçambique, que usará como abreviatura MUVART, é uma instituição de caráter cultural, sem fins lucrativos, que desenvolve a sua actividade no quadro dos presentes estatutos e da legislação em vigor na República de Moçambique. ${ }^{108}$

Portanto, em relação à gestão econômica observa-se que o grupo depende de parcerias que podem vir de setores públicos, privados e do terceiro setor. Ao consultar os catálogos das Bienais de Arte Contemporânea, podem-se enumerar os principais patrocinadores ${ }^{109}$ deste evento:

- Ministério da Cultura

- Tv Cabo

- Cooperação Portuguesa

- Instituto Camões

- Centro Cultural Franco Moçambicano

- República Francesa

\footnotetext{
${ }^{107}$ Expo-Arte Contemporânea, Maputo, Moçambique, catálogo da mostra, 2004, p.4.

108 Certidão de criação do Movimento de Arte Contemporânea de Moçambique, (ver Anexo A), Capitulo I art. $1^{\circ}$.

${ }^{109}$ Expo-Arte Contemporânea, Maputo, Moçambique, catálogo da mostra, 2004, s/p.
} 
- Ministério da Cultura, Brasil

- Fundação Palmares, Brasil

Outro aspecto a realçar é o objetivo do grupo também descrito no cap. I, artigo $3^{\text {ํ110. }}$

A MUVART visa activar e promover a arte contemporânea dentro e fora de Moçambique, através de actividades artísticas do conceito contemporâneo, tais como:

a) Praticar atelieres de pintura, escultura, gráficas, multimédias, vídeo, instalações, performance, land art, etc.;

b) Desenvolver actividades de sensibilização, designadamente conferências, debates, workshops, sociologia das artes, crítica das artes, etc;

c) Desenvolver a difusão artística, através de exposições colectivas e individuais, de caráter nacional e internacional;

d) Promover actividades pedagógicas, leccionando aulas de arte para adultos, crianças ou jovens.

Em retrospectiva, constata-se que o MUVART vem ao longo de sua existência cumprindo seu propósito, tendo na Bienal de Arte Contemporânea seu evento de maior visibilidade nacional e internacional. Divididos entre efectivos, contribuintes e honorários, os membros do grupo seguem alterando a cena artística. Estas formas de participação são descritas no documento (ver Anexo A) de criação do MUVART, assim como sua constituição, tendo em 2011 Gemuce Hilário como Presidente e Jorge Dias, como Vice-Presidente.

Sublinhando o constante fluir e refluir artístico além dos onze artistas iniciais, completamos esse panorama com mais três, quais sejam; Lourenço Pinto, Maimuna Adam e Mauro Pinto. A mostra coloca as diferentes técnicas identificadas com a matriz artística contemporânea; o vídeo, a fotografia, a instalação. Salientamos que mesmo aderindo a novas tecnologias é comum os artistas moçambicanos transitarem em várias linguagens artísticas, tais como o desenho, a gravura, a pintura, a escultura e a cerâmica; observar no Tabela 2.

\footnotetext{
${ }^{110}$ Certidão de criação do Movimento de Arte Contemporânea de Moçambique (ver Anexo A), capítulo I, art. $3^{\circ}$.
} 


\subsubsection{Novas propostas de produção da arte contemporânea na arte moçambicana}

Um dos principais objetivos do artista é mostrar o seu trabalho, conseguir comunicar-se com o público. O que o mercado de arte contemporânea demanda, nos principais centros de arte no mundo, nomeadamente Europa e Estados Unidos, é a inserção desse artista no mercado globalizado. Refletindo dentro destas perspectivas, no meu entender, a produção moçambicana reúne condições para integrar-se nesse universo.

Os critérios definidos na escolha dos artistas pesquisados foram:

1. Nomeação dos artistas fundadores do MUVART.

2. Exigência de participação em no mínimo ${ }^{111} 1$ (uma) das Bienais do MUVART, considerando as edições de 2004, 2006, 2008 e 2010.

3. Inserção de novas participações e linguagens artísticas na Bienal do MUVART.

Em 2010, quando da minha estada em Maputo, realizei entrevistas com vários artistas do MUVART; dos onze fundadores do grupo, as exceções foram apenas de cinco artistas; Mondlane, Lourenço Eugenio Cossa (que se encontrava no Brasil), Quentin Lambert (ausente de Maputo), Vania Lemos e Xavier M'Beve. Todos foram contatados posteriormente via e-mail, inserindo-se assim na pesquisa.

O Movimento de Arte Contemporânea de Moçambique, MUVART, surge da ideia de trazer à cidade novas propostas que são consequência das experiências vividas por cada um desses artistas ${ }^{112}$ num diálogo que surge entre pares.

A manutenção do ofício do artista é muito difícil para a maioria das pessoas que pretende se profissionalizar e viver desta forma, pois frequentemente sua atividade artística é interrompida por vários motivos alheios à arte, que podem ir até a dedicação a uma formação artística em outros níveis, até outras atividades pessoais e/ou profissionais, que nem sempre conjugam com a própria formação

${ }^{111} \mathrm{O}$ artista Lourenço Eugenio Cossa (Xikhossa, nome artístico) é membro fundador do grupo, porém veio estudar no Brasil e se dedicou à formação acadêmica no País desde então.

112 "As folhas", termo cunhado por Malangatana, considera a proposta dos artistas do MUVART, uma perda da tradição, um movimento apartado da história e dos acontecimentos importantes do País, uma arte acrítica, a-histórica, e principalmente não engajada. 
artística ou com a dedicação à sua produção; no caso agora exposto, a maioria dos artistas atua na área, seja como professores ou na publicidade, como Ivan Serra; já Carmem Muianga, artista com diversas premiações e exposições, dedica-se atualmente a concluir sua graduação no Instituto de Artes, ISARC, de Maputo, a primeira faculdade deste porte na cidade.

Desde o inicio o MUVART procurou exercer todas as etapas que envolvem a produção de um evento desta importância; uma Bienal, desde a proposição ao Museu Nacional de Arte, MUSART, até mesmo à programação junto aos artistas. Neste aspecto a Bienal tem sido um laboratório e um conglomerado de parcerias:

O Muvart propôs uma curadoria multi-disciplinar composta por Alda Costa (Historiadora de Arte e Museóloga); José Teixeira (Antropólogo); Filimone Meigos (Sociólogo); Harun Harun (Curador do Museu Nacional de Arte); Jorge Dias (artista e Coordenador da Curadoria), Ivan Serra, Marcos Bonifácio e Anésia Manjate (artistas fundadores do Muvart). Esta curadoria permitiu não só um debate aberto sobre a estética moçambicana e universal em fase de transformação permanente, mas também um olhar crítico sobre o fenômeno da arte e suas novas manifestações. ${ }^{113}$

Desde então, todos os profissionais envolvidos na área das artes em Moçambique vêm se capacitando continuamente; mesmo o espaço arquitetônico do Museu de Arte Nacional, MUSART, vem ganhando fôlego e aprimorando seu equipamento expositivo para melhor atender as demandas que vêm surgindo. No que se refere à Bienal, todas as edições promoveram intercâmbio entre os artistas moçambicanos e os artistas estrangeiros, na forma de palestras, visitas aos ateliês, e mesmo a ampliação da rede estabelecida com o contato entre os artistas que é inevitável num evento deste porte.

${ }^{113}$ Expo-Arte Contemporânea, op. cit., 2004, p.9. 
Tabela 1 Artistas Fundadores do Movimento de Arte Contemporânea de Moçambique, MUVART.

\begin{tabular}{|c|c|c|c|c|c|c|}
\hline ARTISTAS & PROCEDÊNCIA & NASCIMENTO & IDADE & RESIDÊNCIA & FORMAÇÃO & TÉCNICA \\
\hline $\begin{array}{l}\text { 1.Anésia } \\
\text { Manjate }\end{array}$ & $\begin{array}{l}\text { Maputo } \\
\text { Moçambique }\end{array}$ & 1976 & 35 & Maputo & $\begin{array}{c}\text { Superior- } \\
\text { Educação } \\
\text { (Moçambique) }\end{array}$ & $\begin{array}{l}\text { Escultura, } \\
\text { Instalação }\end{array}$ \\
\hline $\begin{array}{l}\text { 2.Carmen } \\
\text { Muianga }\end{array}$ & $\begin{array}{l}\text { Maputo } \\
\text { Moçambique }\end{array}$ & 1974 & 37 & Maputo & $\begin{array}{c}\text { Superior- } \\
\text { Incompleto } \\
\text { Arte } \\
\text { (Moçambique) }\end{array}$ & Gravura \\
\hline 3.Gemuce & $\begin{array}{l}\text { Quelimane, } \\
\text { Zambézia }\end{array}$ & 1963 & 48 & Maputo & $\begin{array}{l}\text { Superior-Arte } \\
\text { Kiev, Ucrânia }\end{array}$ & $\begin{array}{c}\text { Desenho, } \\
\text { Pintura, } \\
\text { Instalação, } \\
\text { Vídeo } \\
\end{array}$ \\
\hline 4. Ivan Serra & $\begin{array}{l}\text { Maputo } \\
\text { Moçambique }\end{array}$ & 1978 & 33 & Maputo & $\begin{array}{c}\text { Superior-Arte } \\
\text { Durban, } \\
\text { República da } \\
\text { África do Sul }\end{array}$ & $\begin{array}{l}\text { Escultura, } \\
\text { desenho, } \\
\text { pintura e } \\
\text { videoarte }\end{array}$ \\
\hline 5.Jorge Dias & $\begin{array}{l}\text { Maputo } \\
\text { Moçambique }\end{array}$ & 1972 & 39 & Maputo & $\begin{array}{c}\text { Superior- } \\
\text { Arte (Brasil) }\end{array}$ & $\begin{array}{l}\text { Pintura, } \\
\text { Escultura, } \\
\text { Fotografia, } \\
\text { Vídeo, } \\
\text { Instalação }\end{array}$ \\
\hline $\begin{array}{l}\text { 6.Lourenço } \\
\text { Eugenio } \\
\text { Cossa }\end{array}$ & $\begin{array}{l}\text { Maputo } \\
\text { Moçambique }\end{array}$ & 1969 & 42 & Brasil & $\begin{array}{l}\text { Superior-Arte } \\
\text { (Brasil) }\end{array}$ & Cerâmica \\
\hline $\begin{array}{l}\text { 7.Marcos } \\
\text { Bonifácio, } \\
\text { "Muthewuye" }\end{array}$ & $\begin{array}{l}\text { Manjacaze } \\
\text { Gaza }\end{array}$ & 1972 & 39 & Maputo & $\begin{array}{l}\text { Superior-Arte } \\
\text { (Cuba) }\end{array}$ & $\begin{array}{l}\text { Escultura, } \\
\text { Cerâmica, } \\
\text { Instalação, } \\
\text { Performance }\end{array}$ \\
\hline 8. Mondlane & $\begin{array}{l}\text { Maputo } \\
\text { Moçambique }\end{array}$ & 1972 & 39 & Maputo & $\begin{array}{c}\text { Superior - } \\
\text { História } \\
\text { (Moçambique) }\end{array}$ & $\begin{array}{l}\text { Desenho, } \\
\text { Escultura, } \\
\text { Cerâmica }\end{array}$ \\
\hline $\begin{array}{l}\text { 9.Quentin } \\
\text { Lambert }\end{array}$ & França & 1970 & 41 & $\begin{array}{l}\text { Sydney, } \\
\text { Austrália }\end{array}$ & $\begin{array}{c}\text { Superior } \\
\text { Completo, } \\
\text { História } \\
\text { (França) } \\
\end{array}$ & $\begin{array}{l}\text { Pintura, } \\
\text { Literatura }\end{array}$ \\
\hline $\begin{array}{l}\text { 10.Vania } \\
\text { Lemos }\end{array}$ & $\begin{array}{l}\text { Maputo } \\
\text { Moçambique }\end{array}$ & 1962 & 49 & Maputo & $\begin{array}{c}\text { História e } \\
\text { Geografia } \\
\text { (Moçambique) }\end{array}$ & Pintura \\
\hline $\begin{array}{l}\text { 11.Xavier } \\
\text { M'Beve }\end{array}$ & $\begin{array}{l}\text { Maputo } \\
\text { Moçambique }\end{array}$ & 1974 & 37 & Maputo & $\begin{array}{c}\text { Superior- Arte } \\
\text { (Brasil) }\end{array}$ & $\begin{array}{l}\text { Gravura, } \\
\text { Escultura }\end{array}$ \\
\hline
\end{tabular}

Fonte: Isa Bandeira 
Tabela 2 Artistas convidados a participar da Bienal Expo-Arte Contemporânea, organizada pelo Movimento de Arte Contemporânea de Moçambique, MUVART.

\begin{tabular}{|l|l|c|c|c|c|c|c|}
\hline ARTISTAS & PROCEDÊNCIA & NASCIMENTO & IDADE & RESIDÊNCIA & FORMAÇÃO & TÉCNICA & BIENAL \\
\hline $\begin{array}{l}1 . \\
\text { Lourenço } \\
\text { Pinto }\end{array}$ & Maputo & 1980 & 31 & Maputo & $\begin{array}{c}\text { Superior- } \\
\text { Arquitetura } \\
\text { (Maputo) }\end{array}$ & Desenho & 2004 \\
\hline $\begin{array}{l}\text { Maimuna } \\
\text { Adam }\end{array}$ & Map̧uto & 1984 & 27 & Maputo & $\begin{array}{c}\text { Superior-Arte } \\
\text { (Pretória, } \\
\text { África do Sul) }\end{array}$ & $\begin{array}{c}\text { Vídeo, } \\
\text { pintura, } \\
\text { fotografia }\end{array}$ & $\begin{array}{c}2008 \text { e } \\
2010\end{array}$ \\
\hline $\begin{array}{l}\text { 3.Mauro } \\
\text { Pinto }\end{array}$ & $\begin{array}{l}\text { Maputo } \\
\text { Moçambique }\end{array}$ & 1974 & 39 & Maputo & $\begin{array}{c}\text { Ensino } \\
\text { Médio-12º } \\
\text { ano }\end{array}$ & $\begin{array}{c}\text { Fotografia, } \\
\text { Pintura }\end{array}$ & 2006 \\
\hline
\end{tabular}

Fonte: Isa Bandeira 
Tabela 3 Número de participações como expositores na Bienal Expo-Arte Contemporânea do Movimento de Arte Contemporânea de Moçambique, MUVART.

\begin{tabular}{|c|c|c|c|c|c|c|}
\hline ARTISTAS & 2004 & 2006 & 2008 & 2010 & $\begin{array}{c}\text { Total de } \\
\text { participações }\end{array}$ & $\begin{array}{l}\text { LOCAL DA } \\
\text { EXPOSIÇÃO }\end{array}$ \\
\hline $\begin{array}{l}\text { 1. Anésia } \\
\text { Manjate }\end{array}$ & EXPOSITOR & EXPOSITOR & EXPOSITOR & & 3 & MUSART \\
\hline $\begin{array}{l}\text { 2. Carmen } \\
\text { Muianga }\end{array}$ & EXPOSITOR & & & & 1 & MUSART \\
\hline 3. Gemasse & EXPOSITOR & EXPOSITOR & EXPOSITOR & EXPOSITOR & 4 & MUSART \\
\hline 4. Ivan Serra & EXPOSITOR & EXPOSITOR & & & 2 & MUSART \\
\hline 5. Jorge Dias & EXPOSITOR & & EXPOSITOR & & 2 & MUSART \\
\hline \multicolumn{7}{|l|}{$\begin{array}{l}\text { 6. Lourenço } \\
\text { Eugenio } \\
\text { Cossa } \\
\end{array}$} \\
\hline $\begin{array}{l}\text { 7. Lourenço } \\
\text { Pinto }\end{array}$ & EXPOSITOR & & & & 1 & MUSART \\
\hline $\begin{array}{l}\text { 8. Maimuna } \\
\text { Adam }\end{array}$ & & & EXPOSITOR & EXPOSITOR & 2 & MUSART \\
\hline 9. Mauro Pinto & & EXPOSITOR & & & 1 & MUSART \\
\hline $\begin{array}{l}\text { 10. Marcos } \\
\text { Bonifácio, } \\
\text { "Muthewuye" }\end{array}$ & EXPOSITOR & & EXPOSITOR & EXPOSITOR & 3 & MUSART \\
\hline 11. Mondlane & EXPOSITOR & EXPOSITOR & & & 2 & MUSART \\
\hline $\begin{array}{l}\text { 12. Quentin } \\
\text { Lambert }\end{array}$ & EXPOSITOR & & & & 1 & MUSART \\
\hline $\begin{array}{l}\text { 13. Vania } \\
\text { Lemos }\end{array}$ & EXPOSITOR & & & & 1 & MUSART \\
\hline $\begin{array}{l}\text { 14. Xavier } \\
\text { M'Beve }\end{array}$ & EXPOSITOR & & & & 1 & MUSART \\
\hline TOTAL & & & & & 24 & \\
\hline
\end{tabular}

Fonte: Isa Bandeira 
Tabela 4 Participações de Países e Artistas na Bienal de Arte Contemporânea

\begin{tabular}{|c|c|c|c|c|}
\hline Bienal/Países & 2004 & 2006 & 2008 & 2010 \\
\hline Angola & & & & 1 \\
\hline Argentina & & 1 & & \\
\hline África do Sul & 1 & & & \\
\hline Brasil & 6 & 5 & 1 & 2 \\
\hline Chile & & & & 1 \\
\hline Espanha & 1 & 1 & & \\
\hline EUA & & 1 & & 2 \\
\hline França & 2 & 1 & & \\
\hline Guiné Bissau & & 1 & & \\
\hline Itália & & & 2 & \\
\hline Moçambique & 25 & 13 & 15 & 10 \\
\hline Portugal & 1 & 6 & & 1 \\
\hline $\begin{array}{c}\text { República } \\
\text { Checa }\end{array}$ & 1 & & & \\
\hline Total & 37 & 30 & 18 & 17 \\
\hline
\end{tabular}

Fonte: Isa Bandeira 
Percebe-se que a parceria com o Brasil tem sido intensa e profícua, ver tabela 4, totalizando 14 participações desde a sua primeira edição, perdendo apenas para o anfitrião em número de expositores. Ao longo do tempo a mostra tem se fixado no calendário cultural da cidade e continua levando novas propostas de produção da arte contemporânea a Moçambique.

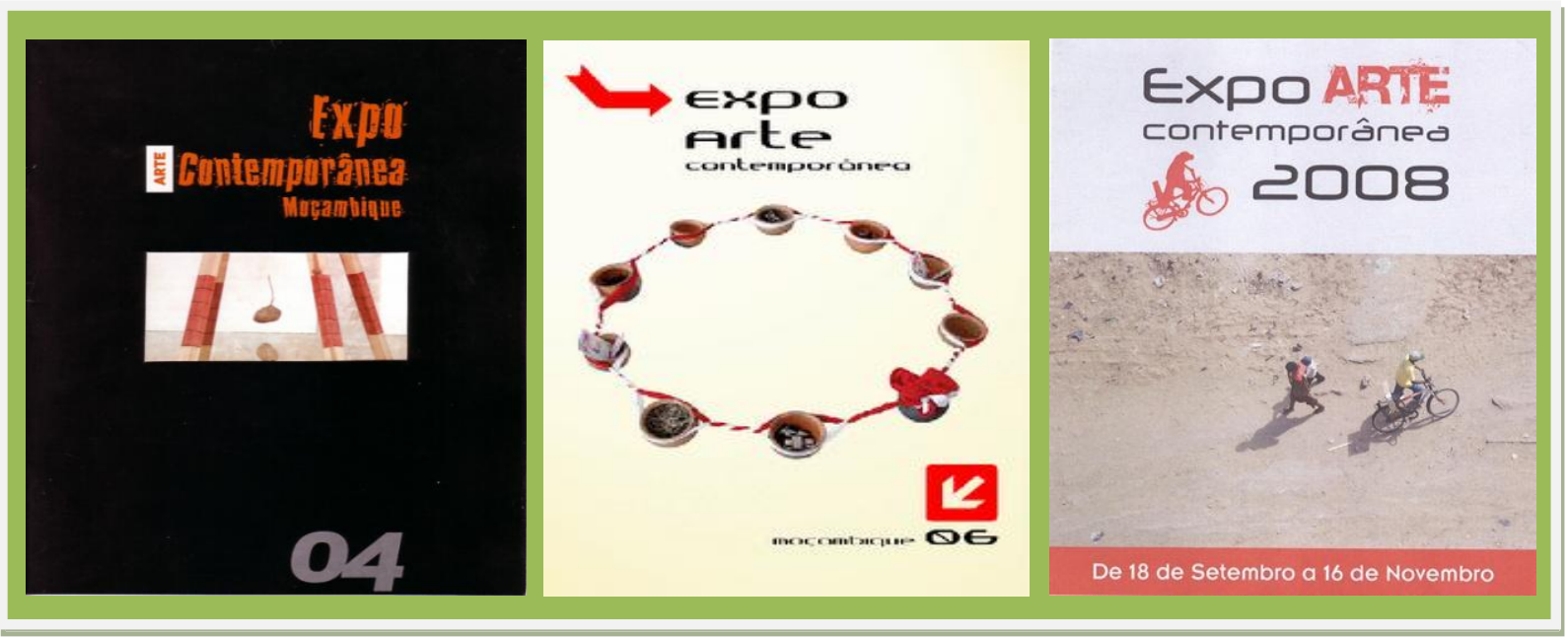

Figura 31

Catálogos da Expo-Arte Contemporânea, Moçambique.

Bienais de 2004, 2006, 2008.

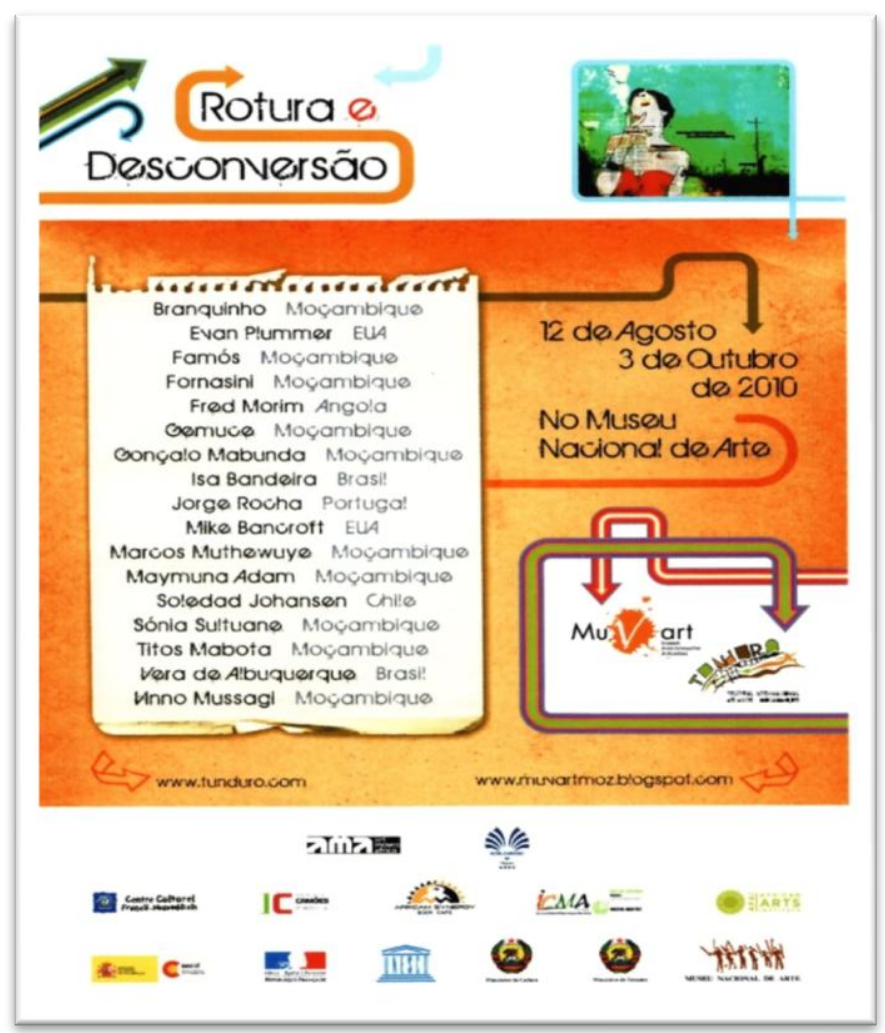

Figura 32

Catálogos da Expo-Arte Contemporânea, Moçambique.

Bienal de 2010. 
Nas figuras 31 e 32, as capas dos Catálogos da Bienal de Arte Contemporânea, nas três primeiras edições 2004, 2006 e 2008, colocam em destaque as obras dos respectivos artistas moçambicanos: Victor Sousa, Anésia Manjate e Gemuce. A última capa, edição 2010, traz um detalhe do trabalho do artista angolano, Fred Morim. Ressalta-se a importância dos catálogos como documentos de registro e como fonte de pesquisa.

Observados os principais pontos referentes à arte contemporânea em Maputo, e seus principais agentes, passa-se à apresentação destas visualidades, ou seja, as obras, que não foram necessariamente produzidas para integrar a mostra Expo-Arte Contemporânea. Uma vez que a maioria já tinha sido criada, todos os trabalhos expostos passaram pela constituição de uma curadoria e estavam fundamentadas nas questões de debate da arte contemporânea.

Sobre esta perspectiva, Jorge Dias, vice-presidente do MUVART, em texto assinado na última edição da bienal intitulada "Ruptura e Desconversão", 2010, frisa:

A exposição "Ruptura e Desconversão" do programa do MUVART "Expo Arte Contemporânea Moçambique" existe há 6 anos, com caráter de uma bienal. Este evento, pretende sensibilizar, teorizar e estimular a produção de arte contemporânea através de sua circulação dentro e fora do país. É a IV edição e tem como objectivo, a troca de experiências entre os artistas participantes, a circulação das produções actuais, possibilitando deste modo o conhecimento a informação e debate sobre a arte contemporânea. ${ }^{114}$

Acima de tudo, o MUVART afirma neste texto a missão contida em sua origem, quando da criação formal do grupo: promover o intercâmbio e o debate da arte. Neste contexto o grupo propiciou outras demandas e mais artistas foram se destacando no cenário nacional, tais como Lourenço Pinto, Maimuna Adam e Mauro Pinto.

${ }^{114}$ Expo-Arte Contemporânea, Maputo, Moçambique, catálogo da mostra, 2010, s/p. 


\subsection{OUTROS INTERLOCUTORES, OUTROS MOVIMENTOS}

Além dos fundadores do Movimento de Arte Contemporânea de Moçambique, MUVART, selecionaram os artistas Lourenço Pinto, Maimuna Adam e Mauro Pinto para participar da Bienal Expo-Arte Contemporânea, nas edições de 2004, 2006, 2008 e 2010. O desenho, o vídeo, a instalação e a fotografia foram os suportes escolhidos por eles.

Lourenço Pinto, arquiteto de formação, apoia-se na linguagem do desenho; identifica-se uma abordagem contemporânea pelo artista, mesmo sendo esta considerada uma técnica mais clássica.

Maimuna Adam ${ }^{115}$ é a artista mais jovem do grupo. Em 2004, aproxima-se das atividades do Movimento de Arte Contemporânea de Moçambique, MUVART, trabalhando na primeira Bienal. Dando suporte técnico ao blog construído na ocasião, interage com o evento acompanhando a programação. Depois de sua formação na África do Sul, retorna a Maputo, agora no papel de artista, e vem consolidando seu trabalho na linguagem da instalação e do vídeo, mas também assume outras linguagens como o desenho, a pintura e a fotografia, característica percebida entre os artistas moçambicanos, de trafegar em diversas áreas.

Diferentemente, Mauro Pinto elegeu a fotografia. Tendo seu início de carreira atrelado ao fotojornalismo, percorre um caminho mais identificado com a arte contemporânea. Assim como Maimuna Adam, Mauro Pinto ${ }^{116}$ engaja-se em discussões dentro das perspectivas sociais, sendo seus projetos também pautados nestes objetivos. Nota-se que a iniciativa do grupo fundador do Movimento de Arte Contemporânea de Moçambique, MUVART, de agregar e expandir o cenário artístico das artes em Moçambique tem aproximado velhas e novas gerações.

\footnotetext{
${ }^{115}$ Maimuna Adam executa trabalhos de ilustração para WLSA - Women and Law Southern Africa Research and Education Trust é uma organização não governamental regional (ONG), que faz pesquisa sobre a situação dos direitos das mulheres em sete países da África Austral: Botswana, Lesotho, Malawi, Moçambique, Swazilândia, Zâmbia e Zimbabwe.

${ }^{116} \mathrm{O}$ fotógrafo integra a ONG Justiça Ambiental.
} 


\subsubsection{Lourenço Pinto}

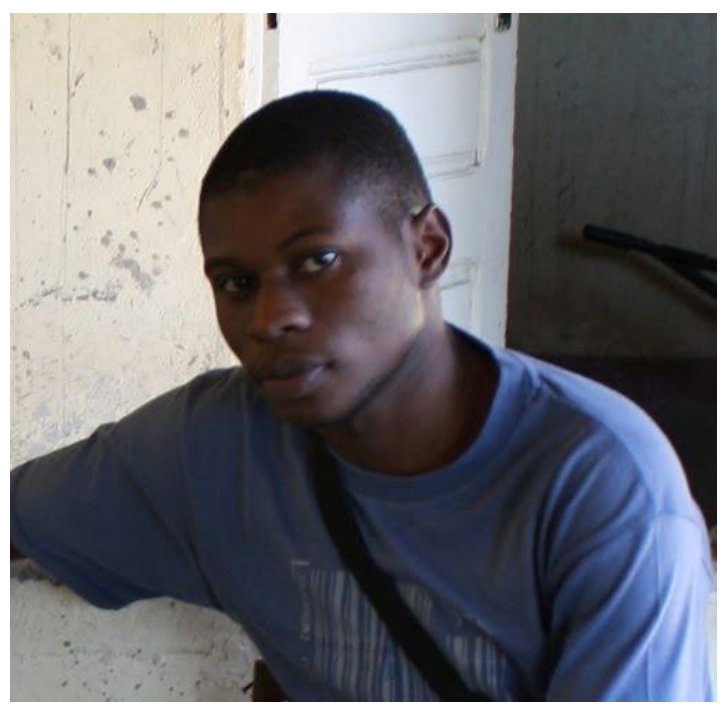

Figura 33

\section{Lourenço Pinto}

Vive e trabalha em Maputo, Moçambique

Lourenço Dinis Pinto nasceu em Maputo em 1980 e frequentou a Escola de Artes Visuais, ENAV, na mesma cidade, concluindo o curso de Design Gráfico. Posteriormente estudou Arquitetura e Planeamento Físico na Universidade Eduardo Mondlane ${ }^{117}$, também em Maputo. Expõe regularmente desde o final dos anos de 1990, participando de exposições coletivas em Moçambique, Portugal e outros países africanos e europeus. Em 2004, participa da primeira Expo-Arte Contemporânea, organizada pelo Movimento de Arte Contemporânea de Moçambique, MUVART.

Com sua linguagem artística voltada exclusivamente para o desenho, passa a agregá-la sobre outros suportes, tais como equipamentos multimídias e demais objetos. O itinerário da exposição trouxe uma gama de informações que ampliaram o cenário artístico e a apreciação das obras.

Lourenço Pinto participou em 2004 da Expo-Arte Contemporânea, no Museu Nacional de Arte, MUSART, em Maputo, a primeira Bienal organizada pelo Movimento de Arte Contemporânea de Moçambique, MUVART, com um trabalho intitulado Música de Sonho (Toque Uma ao Seu Gosto) (Fig. 34).

${ }^{117}$ Adotou-se a nomenclatura original do curso. 
Sobre o seu trabalho PINTO comenta:

Com este trabalho pretendo fazer uma ponte entre o tempo em que se fazia música considerada antiga "nos dias de hoje" (Funk, Blues, Raggae, Rock, Jazz, etc), com a música feita hoje, com recursos à tecnologia.Tudo isto para responder a uma difícil pergunta: de que tipo de música é que gosta? Concentre-se e oiça a música das linhas que o desenho lhe propõe e seja feliz. ${ }^{118}$

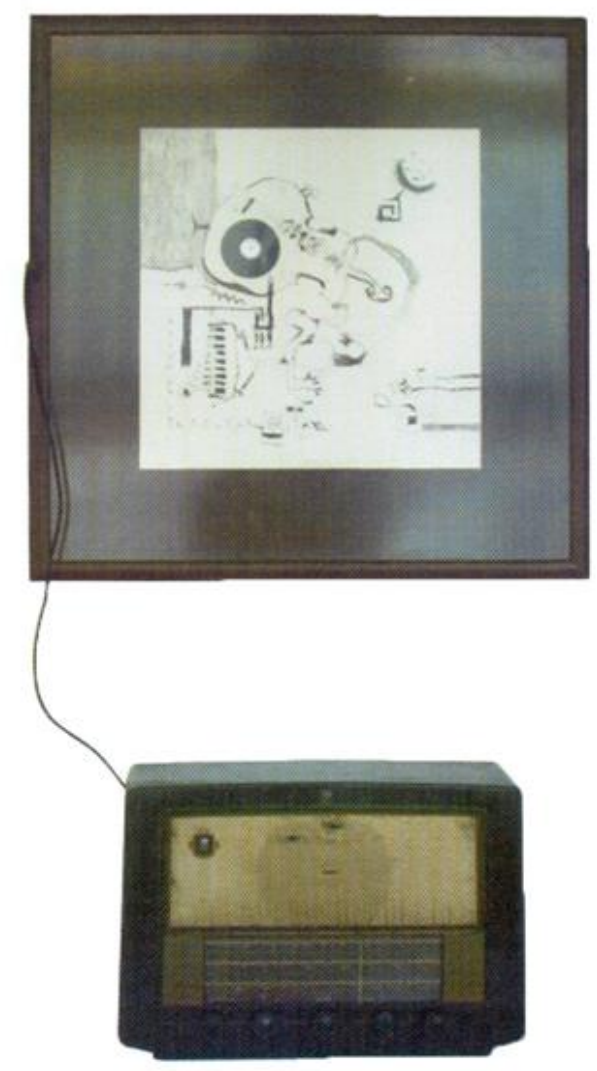

Figura 34

Lourenço Pinto

Música de Sonho

(Toque uma ao seu gosto)

Sépia, papel de aquarela, disquete, rádio antigo $82 \times 81 \mathrm{~cm}$; 2004

Após a definição do artista sobre o seu próprio trabalho percebe-se que PINTO se apropria da liberdade expressiva possibilitada na Expo-Arte Contemporânea, 2004, e alia ao seu desenho outro panorama. Traz ao público moçambicano outra comunicação visual com a sua obra, provocando um novo olhar ao agregar um objeto ao desenho.

A técnica utilizada pelo artista é frequentemente o desenho. Utiliza o carvão, tendo como suporte o cartão e o papel de aquarela, sendo o carvão um dos materiais mais antigos do desenho. Através de cenas do quotidiano, PINTO traça

${ }^{118}$ Expo-Arte Contemporânea, op. cit., 2004, p.37. 
com lirismo suas linhas. Mesmo quando a narrativa propõe situações limítrofes, o artista dosa as suas imagens em preto e branco sem utilizar a técnica do claro/escuro e os jogos de sombra, mais identificados com a matriz do Renascimento.

Em recente exposição realizada em Lisboa o trabalho do jovem artista e seu contemporaneo é descrito desta forma:

\begin{abstract}
Ídasse e Pinto representam duas gerações de artistas moçambicanos, na medida em que o primeiro experienciou a guerra colonial, enquanto 0 segundo nasceu após a independência de Moçambique. Porém, o seu trabalho constitui as duas faces da mesma moeda: por um lado esperançoso, pleno de utopia; por outro, rendido às vicissitudes de uma vida quotidiana martirizada pelas vãs promessas políticas. Com uma linguagem de pendor lírico e recorrendo a técnicas narrativas como a fábula e a alegoria, os seus desenhos retratam os sonhos e os problemas do Moçambique contemporâneo. Ídasse e Pinto criam, pois, uma singular visão do mundo, enunciando uma realidade culturalmente tão próxima mas, igualmente, já tão distante do imaginário português. ${ }^{119}$
\end{abstract}

Esta descrição da obra de PINTO é pertinente para compreender de que forma o artista utiliza a linguagem do desenho como técnica, atrelada à realidade moçambicana e fazendo do desenho um dado plástico e uma expressão contemporânea.

Uma linha de análise para os historiadores de arte pode ser pelo viés sociológico, onde o "meio" ao qual os artistas pertencem irá constituir-se como fator estruturador da obra. Sendo a temática de PINTO identificada com a cultura moçambicana, acredita-se que esta poderia ser uma opção de análise do conjunto de sua produção artística.

\footnotetext{
${ }^{119}$ Exposição, "MATXAXULANA + MARRABENTA, Ídasse + Pinto" Fundação PLMJ, Lisboa, 2010.
} 


\subsubsection{Maimuna Adam}

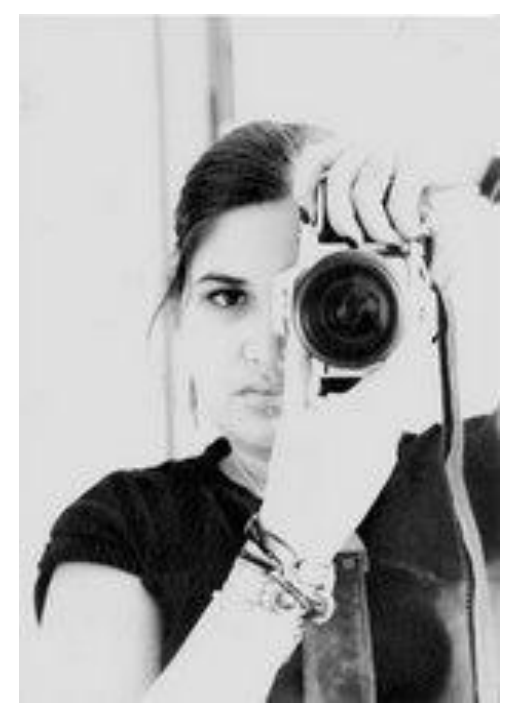

Figura 35

Maimuna Adam

Vive e trabalha em Maputo, Moçambique

Miriam Maimuna Einarsen Adam concluiu a Licenciatura ${ }^{120}$ na Faculdade de Humanas, departamento de Artes Visuais, na Universidade de Pretória na África do Sul, em 2008.

Atua como artista plástica e como professora do Instituto Superior de Artes e Cultura, ISArC, onde lecionou em 2010 Desenho de Artes Visuais e Introdução a Fotografia no curso de Design e em 2011, para a mesma turma do 1ํ Ano, as disciplinas de Desenho e de Introdução ao Design.

Integrou as Bienais Expo-Arte Contemporânea, organizadas pelo Movimento de Arte Contemporânea de Moçambique, MUVART, nas edições de 2008 e 2010.

Sendo uma das primeiras artistas moçambicanas a trabalhar com o vídeo, o seu trabalho traz uma abordagem relacionada à perspectiva da história individual. Em entrevista concedida em julho de 2010, em Maputo, a artista fala da sua trajetória, de seus planos futuros e da importância de trabalhar no Museu Nacional de Arte, MUSART, quando da primeira bienal organizada pelo MUVART, em 2004.

\footnotetext{
${ }^{120}$ Monografia apresentada "Between Diaspora and Globalisation: An interpretation of artworks by The Contemporary Art Movement of Mozambique", Faculty of Humanities, University of Pretoria, 2008.
} 
Posteriormente, ADAM participa já como artista na Expo-Arte Contemporânea $^{121}$ que se realizou no Museu Nacional de Arte, MUSART, em Maputo, em 2008. Com o trabalho intitulado 100\% Moçambicana, uma instalação, a artista estampa sua própria imagem em três camisetas brancas (Fig. 36).

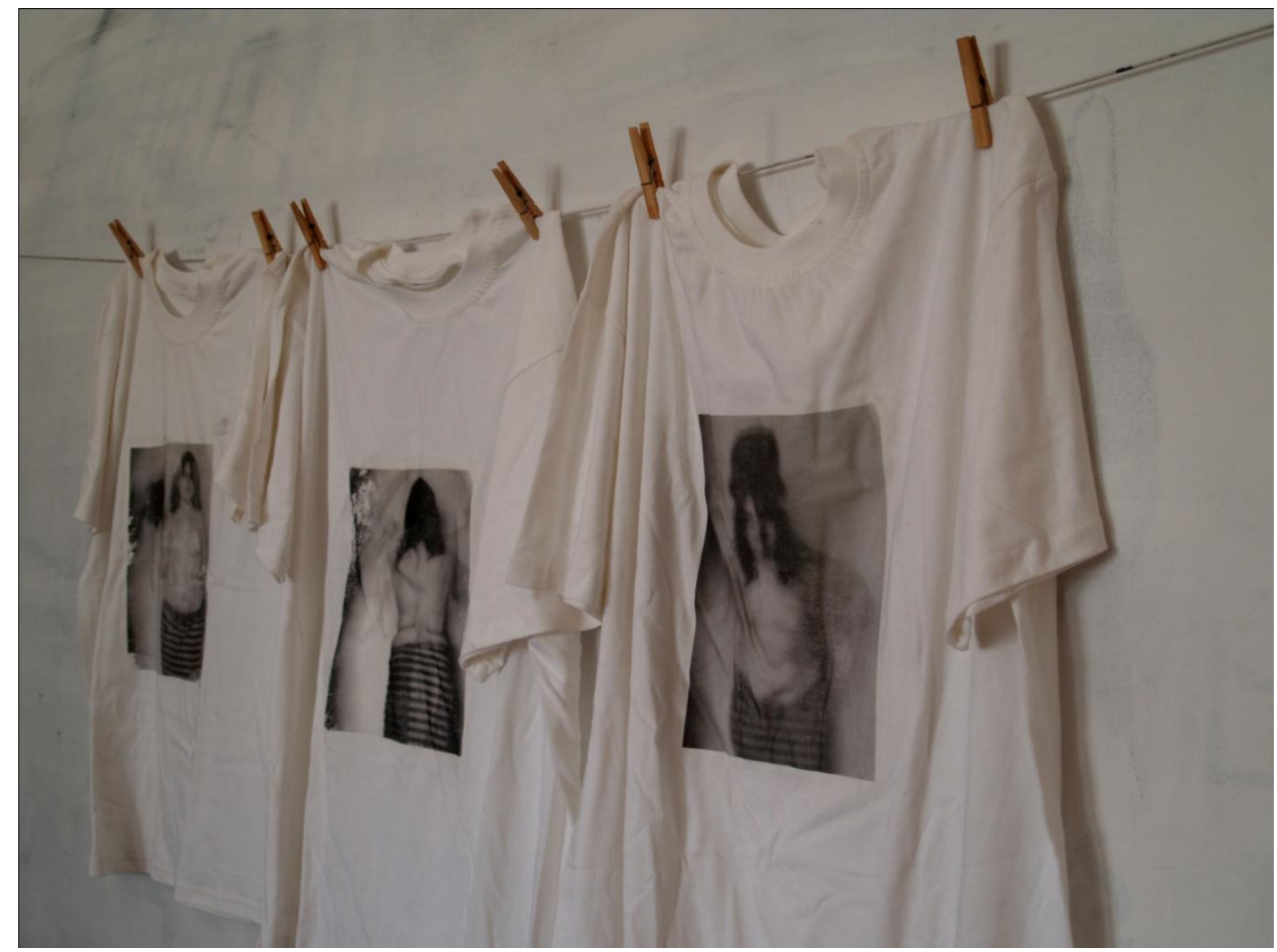

Figura 36 100\% Moçambicana Acervo da Artista

A exposição nomeada Toca do Rato, subtítulo da Bienal Expo-Arte Contemporânea, 2008, contou com a participação, além de Maimuna Adam, dos artistas Amaral, Anésia Manjate, César Torres, David Mbonzo, Gemuce, Geremias, Gonçalo Mabunda, Jorge Dias, Madoricane, Marcos Muthewuye, Miguel Valingue, Naguib, Sílvia Bragança e Ulisses representando Moçambique. Da Itália Emma Vitti e Marilena Sassi; e do Brasil o artista Genivaldo Amorim, contabilizando 18 artistas expositores.

121 Expo-Arte Contemporânea, op. cit., 2008, p.02. 
Maimuna Adam trabalha com diferentes temas, porém entre eles notam-se algumas características comuns, tais como questões: identidade, gênero, ausência, tradição.

Sobre o seu trabalho a artista comenta:

100\% Moçambicana" começou como uma série de fotografias feitas com a técnica 'pinhole' mas digital, onde vesti-me de capulana e usei uma máscara Mapiko. Decidi usar as imagens nesta série de 't-shirts' para 'brincar' um pouco com a idéia das 't-shirts' vendidas na Marginal de Maputo (e em outros sítios), em que a identidade Moçambicana é 'exposta' para ser vendida e consumida (figuras históricas, o emblema da república, lemas como "Moçambique é fixe" e outras imagens). O título do trabalho também ganha significado porque foi feito na África do Sul, e enviado ao Museu Nacional de Arte para a Bienal do MUVART (2008), enquanto eu acabava os estudos em Pretória. ${ }^{122}$

A identidade relacionada à comunidade e ao individual é um caminho explorado neste trabalho; outro aspecto abordado é a ideia de nacionalidade relacionada à tradição com a alusão à Máscara Mapiko; também interagem com as questões de gênero da obra de Maimuna Adam.

A Expo-Arte Contemporânea, 2010, realizou-se no Museu Nacional de Arte, MUSART, em Maputo. Maimuna Adam participa com o trabalho intitulado $O$ Lar/Home Vídeo, 2010 (Fig. 37).

${ }^{122}$ E-mail, 18.maio. 2011. 

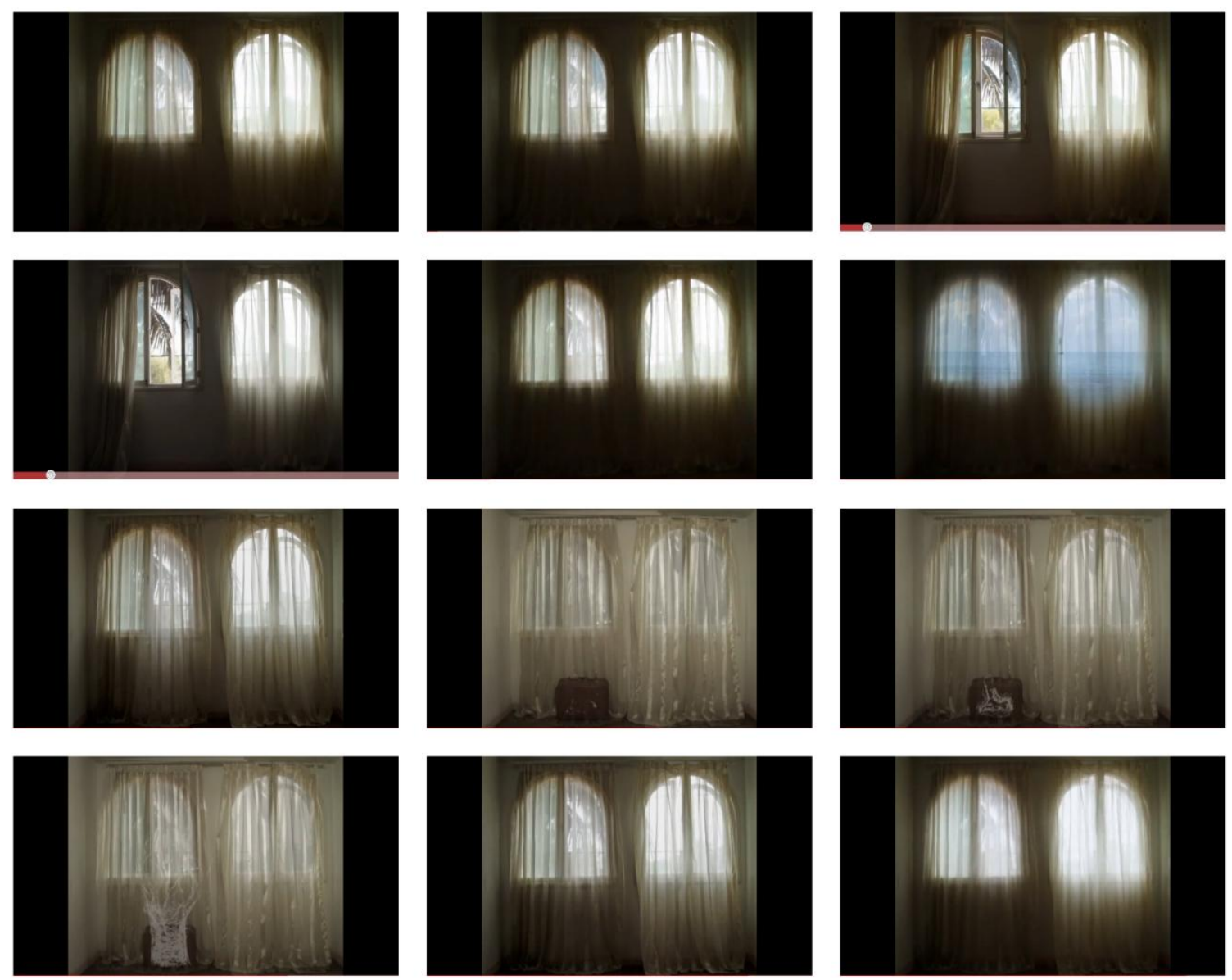

Figura 37 - Maimuna Adam

O Lar/Home Vídeo, 4 min $18 \mathrm{sec}$ (stills)

MUVART EXPO'10 Rotura e Desconversão, Museu Nacional de Arte, Maputo, 2010.

A inclusão do vídeo, e especificamente da artista Maimuna Adam, como uma modalidade da linguagem artística contemporânea vai ao encontro da proposta desta Bienal, como podemos ver no texto assinado pelo Movimento de Arte Contemporânea de Moçambique, MUVART e na apreciação do seu trabalho cuja temática se encontra alinhada ao propósito:

Através de alguns artistas aqui apresentados, a exposição vem dar a conhecer o contorno que a arte contemporânea em Moçambique está a tomar. Estes trabalhos estão virados para uma arte transnacional, que dialogam com universos multiculturais. Os artistas tem vindo a abrir mão de programas estéticos, matrizes nacionalistas e narrativas sócio/político/culturais, por um percurso individual e subjetivo na produção das Artes Visuais nos dias de hoje. Os mesmos encontram seus pares em outras geografias de matriz cultural diferente. ${ }^{123}$

${ }^{123}$ Expo-Arte Contemporânea, op. cit., 2010, p.02. 
Percebe-se a tentativa do Movimento de Arte Contemporânea de Moçambique, MUVART, de apresentar em cada edição um diálogo entre a produção local e a global. Especificamente sobre a linguagem do vídeo diz RUSH:

Seja por meio de narrativas, experimentações formais, teipes humorísticos curtos ou mediações em grande escala, a videoarte, no final do século XX, assumiu uma posição de legitimidade, até mesmo de proeminência, no mundo da arte, que pouquíssimos consideravam possível mesmo nos anos 80. Suas possibilidades aparentemente infinitas e sua relativa acessibilidade tornaram-na cada vez mais atraente para jovens artistas que cresceram em uma era de saturação dos meios de comunicação de massa. O vídeo é uma maneira de participar de, e reagir ao exagero dos meios de comunicação de massa; além disso, é um meio acessível para a transmissão de mensagens pessoais. ${ }^{124}$

A pertinência do trabalho de Maimuna Adam insere-se nesta definição de RUSH; é um percurso coerente na trajetória da artista, e o uso desta linguagem, o vídeo, tem auxiliado a artista nas discussões que vem propondo, como podemos notar no trabalho O Lar/ Home, 2010 (Fig. 37). No cenário moçambicano, as linguagens que demandam tecnologia não são usuais por uma razão: não são acessíveis, isto tornando restrita a sua adoção.

A principal característica na obra em progresso da artista é trazer junto a temática de cunho pessoal; entre outras, a crítica sobre a noção de cultura como podemos observar no trabalho 100\% Moçambicana, 2007. Uma cultura que massifica valores e que destitui o indivíduo de sua história.

${ }^{124}$ RUSH, Michael. Novas Mídias na Arte Contemporânea. São Paulo: Martins Fontes, 2006, p.107. 


\subsubsection{Mauro Pinto}

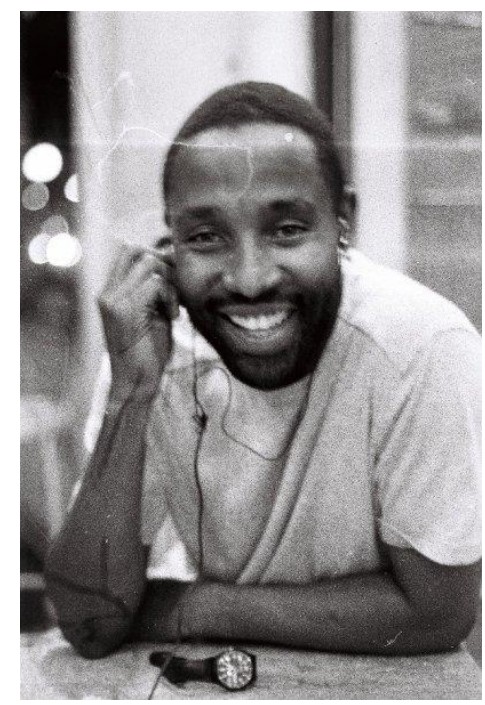

Figura 38

\section{Mauro Pinto}

Vive e trabalha em Maputo, Moçambique

Mauro Jorge M. Pinto, nascido em 1974, em Maputo, Moçambique, é um artista de formação autodidata que se dedica exclusivamente à fotografia. Em 1998 faz estágio com o fotógrafo José Machado. No decorrer do mesmo ano inicia o Professional Photography and Development Course, realizando monitoria na International School, na África do Sul.

Trabalhou também com o fotógrafo Ricardo Rangel (1924-2009) e é um dos fundadores da Associação Moçambicana de Fotografia, AMF.

Desenvolve a sua atividade profissional como professor, com Oficinas Fotográficas para Crianças em Maputo e, em 2003, atuou como assistente do curador geral de Moçambique da World Press Photo.

A Expo-Arte Contemporânea de 2006 traz as fotografias que fazem parte de um projeto a longo prazo, denominado Portos de Convergência, no qual a contemporaneidade pode ser também conhecida como a Era dos Projetos. $\mathrm{Na}$ fotografia de arte muitos profissionais desenvolvem esta metodologia.

Antes de apresentar a produção artística de Mauro Pinto, foi necessário buscar alguns conceitos iniciais sobre o que venha a ser a própria fotografia, KUBRUSLY comenta: 
Afinal, o que é fotografia? A possibilidade de parar o tempo, retendo para sempre uma imagem que jamais se repetirá? Um processo capaz de gravar e reproduzir com perfeição imagens de tudo que nos cerca? Um documento histórico, prova irrefutável de uma verdade qualquer? Ou a possibilidade mágica de preservar a fisionomia, o jeito e até mesmo um pouquinho da alma de alguém de quem gostamos? Ou apenas uma ilusão? Uma ilusão de ótica que engana nossos olhos e nosso cérebro com uma porção de manchas sobre o papel, deixando uma sensação tão viva de que estamos diante da própria realidade retratada? ${ }^{125}$

As considerações explicitadas nesta referência são importantes para fundamentar as questões iniciais da fotografia na sua origem. Porém a fotografia vem ao longo do tempo trazendo outras discussões, segundo COTTON. Para contribuir nesta análise o tema é subdivido em oito linhas de pensamento sobre a estética da fotografia de arte, aqui resumidas:

$1^{\circ}$ Como os fotográfos criam estratégias, performances e eventos especialmente para a câmera.

$2^{\circ}$ Concentração nas narrativas de histórias dentro da fotografia de arte.

3 o Exame da ideia de uma estética fotográfica.

40 Limites do que pode ser considerado um tema visual crível.

5o Concentração nas relações psicológicas e pessoais, como num tipo de diário da intimidade humana.

6 - Capacidade de uso documental da fotografia na arte.

70 Variedade de métodos recentes

$8^{\circ}$ Natureza do meio como parte da narrativa da peça. ${ }^{126}$

Em complementação, KUBRUSLY acredita que o horizonte da fotografia está ampliado, e a dúvida sobre a sua inserção como objeto de arte já não existe. Diante dos pontos identificados por COTTON, poderíamos exercitar em qual deles se enquadraria a obra de Mauro Pinto. Mas ao nosso entender muitos destes pontos se entrelaçam no trabalho do fotógrafo moçambicano.

Único do grupo que trabalha especificamente com esta técnica, Mauro nos possibilita a imersão neste universo e em sua compreensão, componente forte dentro da arte contemporânea. Não é apenas o registro de um lugar, mas também

\footnotetext{
${ }^{125}$ KUBRUSLY, Cláudio A. O que é fotografia. São Paulo: Brasiliense, 2006, p.8.

${ }^{126}$ COTTON, Charlotte. A Fotografia como Arte Contemporânea. São Paulo: Martins Fontes, 2010, p.7-11.
} 
de uma ideia. Esta relação entre a ideia como campo filosófico é discutível neste projeto porque, tratando-se de um fato histórico, este possui uma diversidade de versões.

Em sua participação na Expo-Arte Contemporânea que se realizou no Museu Nacional de Arte, MUSART, em Maputo, em 2006, o artista expõe o trabalho intitulado Portos de Convergência: Angola e a Partida de um Legado Africano, um conjunto de cinco fotografias (Figs. 39 a 43).
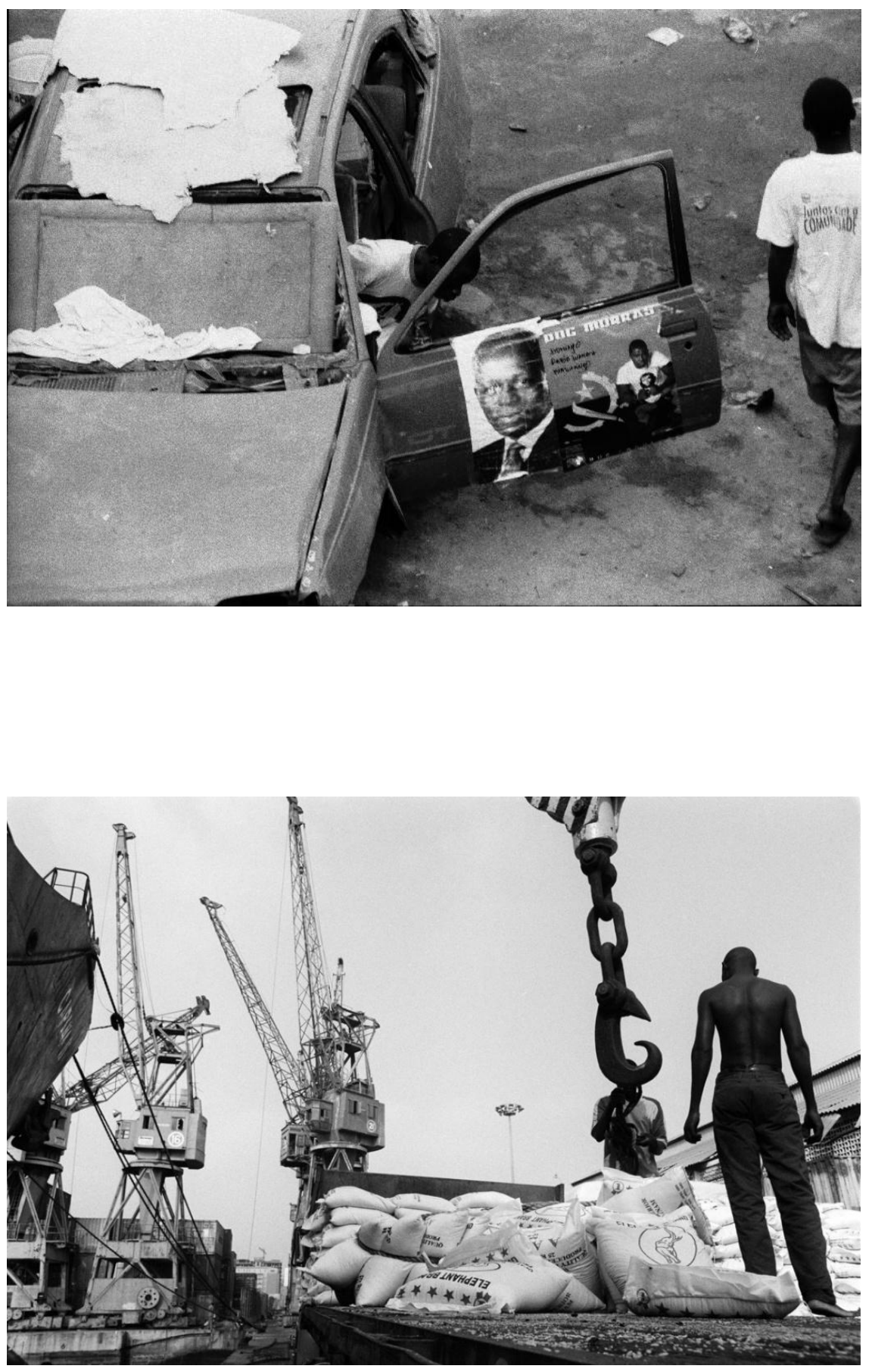

Figura 39 Mauro Pinto

Portos de Convergência: Angola e a Partida de um Legado Africano Luanda

Fotografia $40 \times 30 \mathrm{~cm}$ 2006 Acervo do artista

Figura 40 Mauro Pinto Portos de Convergência: Angola e a Partida de um Legado Africano Luanda Fotografia $40 \times 30 \mathrm{~cm}$ 2006 Acervo do artista 


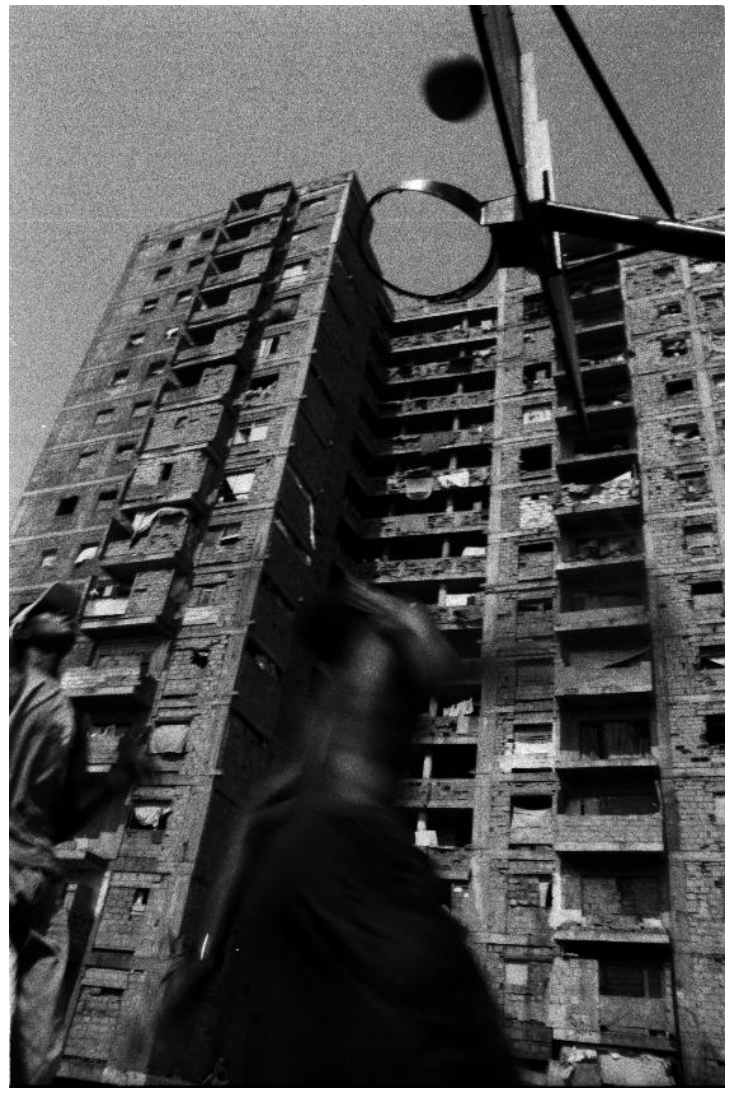

Figura 41 Mauro Pinto

Portos de Convergência: Angola e a Partida de um Legado Africano

Luanda

Fotografia

$40 \times 30 \mathrm{~cm}$

2006

Acervo do artista

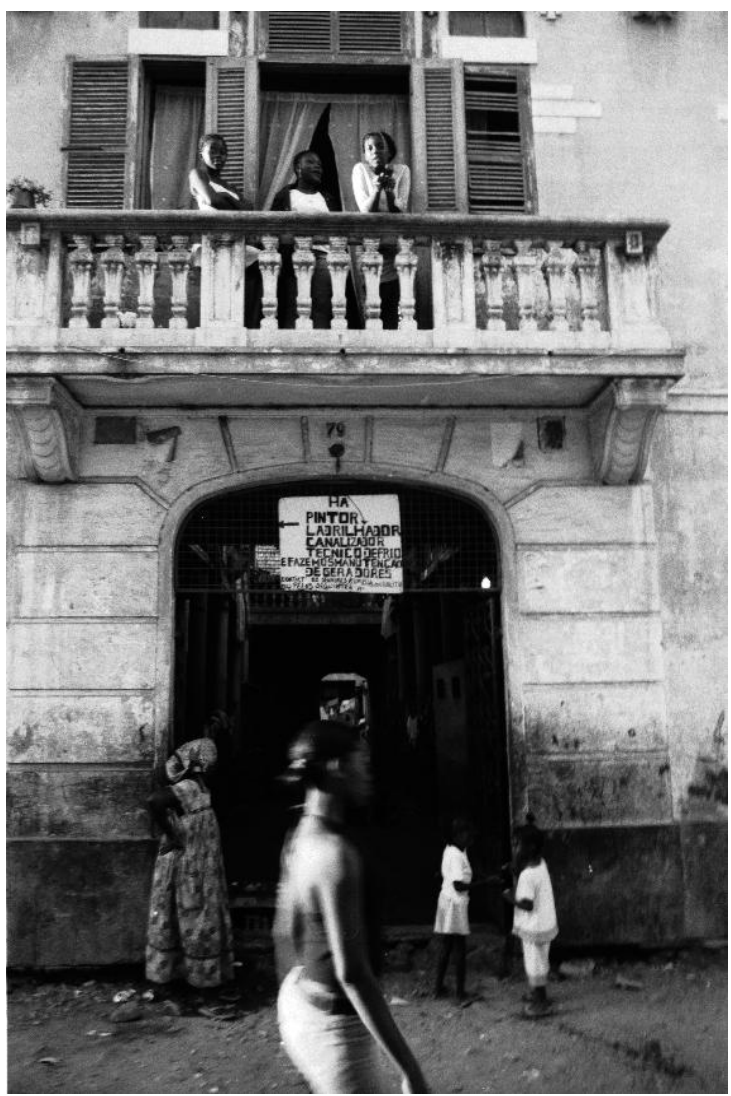

Figura 42 Mauro Pinto

Portos de Convergência: Angola e a Partida de um Legado Africano

Luanda

Fotografia

$40 \times 30 \mathrm{~cm}$

2006

Acervo do artista 


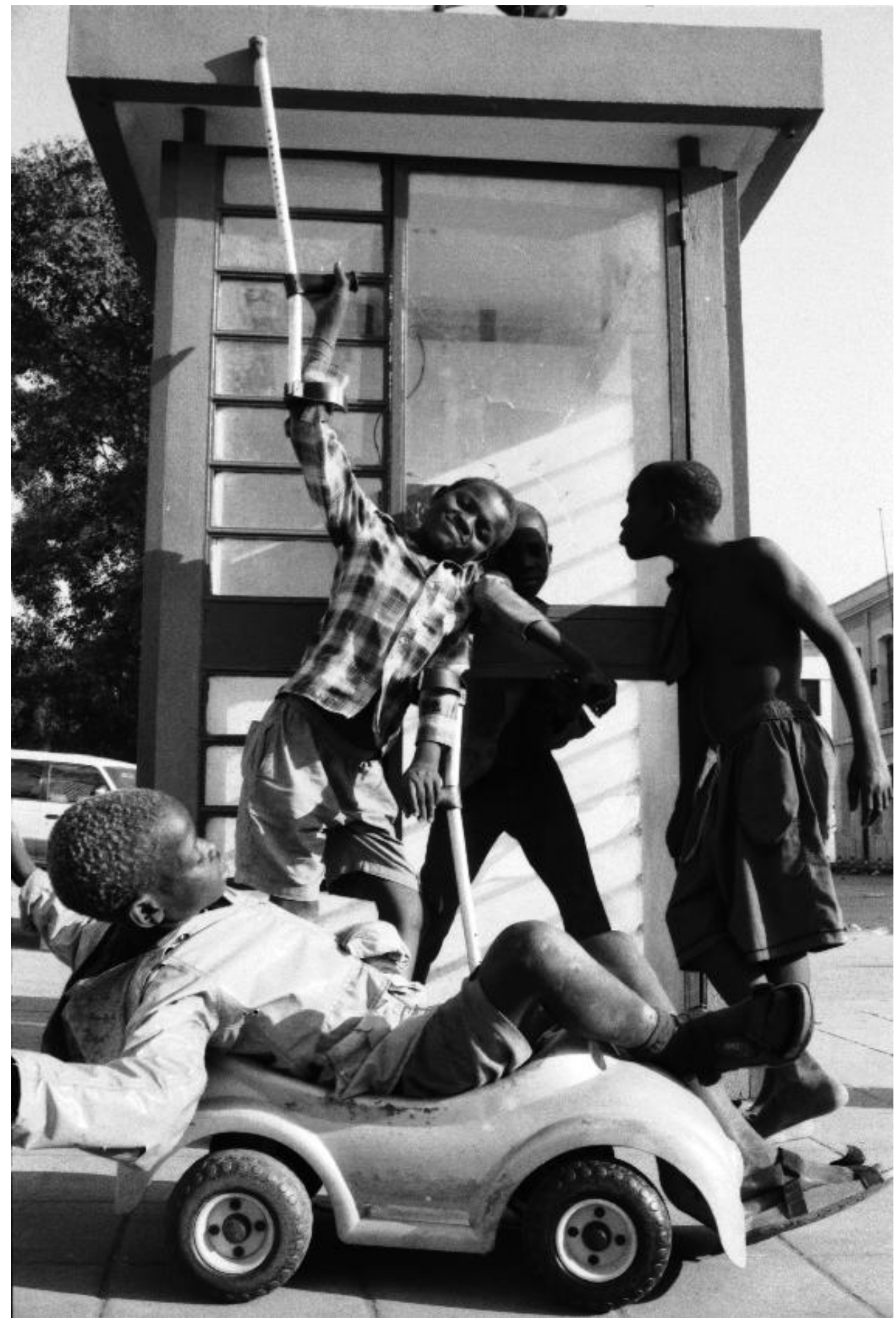

Figura 43 Mauro Pinto

Portos de Convergência: Angola e a Partida de um Legado Africano Luanda

Fotografia

$40 \times 30 \mathrm{~cm}$

2006

Acervo do artista 
Mauro diz no catálogo que seu trabalho é parte de um projeto mais longo, como já salientado.

Portos de Convergência: Angola e a Partida de um Legado Africano

"A experiência do Porto de Luanda é apenas um começo, uma forma de iniciação, em que se pretende expor pedaços e toques do legado Africano levado para outros continentes. Esta exposição faz parte de um projecto ambicioso que investiga como é que as culturas da África Austral desenharam, ao longo da história, o triângulo de ligação entre África América - Europa, através do meio visual da fotografia de rostos/aparências citadinas e vilas costeiras. O enfoque são os portos: historicamente, estes foram os principais pontos da migração massiva e bruta relacionada com o comércio de escravos Africanos...Além disso, o fotógrafo procura estabelecer a ligação entre África e as populações Africanas que migraram, voluntária ou involuntariamente, para outros continentes como a Europa e a América e, desvendar, com os seus próprios olhos, o ambiente onde chegaram, à tantos anos atrás, as pessoas da África Austral." ${ }^{127}$

Perguntado na entrevista sobre o motivo da inclusão do termo "convergência" ao projeto, o fotógrafo comenta "pra falar um pouco da rota da escravatura [...] não só, porque muitos dos Países, muitos escravos saíram e foram para outros Países, dali foram para outros sítios..." ${ }^{128}$ Ainda sobre a temática, acentua que não se fixa apenas nos registros do Porto como locus desta convergência, mas também no seu entorno, nas culturas, nas cidades. A perspectiva do projeto Portos de Convergência é analisar o fluxo do triângulo Europa, América e África. Mauro Pinto já fotografou em Luanda, Ilha da Reunião, Brasil, Congo e Maputo. Este projeto Portos de Convergência: Angola e a Partida de um Legado Africano, 2006 está em processo e soma-se ao principio norteador de apresentar outros interlocutores na cena artística Moçambicana. A inclusão destes três artistas, representa o que mais se aproxima em 2012 do universo artístico atual, ou seja da arte contemporânea no país; sendo jovens, dialogam em proximidade com os ideais artísticos do Movimento de Arte Contemporânea de Moçambique, MUVART.

Isto posto, a arte contemporânea em Maputo é representada em 2004 pelos artistas do MUVART. Na próxima sessão Anésia Manjate, Carmen Muianga, Gemuce, Ivan Serra, Jorge Dias, Lourenço Eugenio Cossa, Marcos "Muthewuye", Mondlane, Quentin Lambert, Vânia Lemos e Xavier M'Beve demonstram por que

${ }^{127}$ Expo-Arte Contemporânea, op. cit., 2006, p. 37.

${ }^{128}$ Entrevista concedida à autora, Maputo, Moçambique, jul.2010. 
vêm confrontando a ideia de arte e influenciado outros artistas tais como Lourenço Pinto, Maimuna Adam e Mauro Pinto que evidentemente trilham um caminho próprio. 
AS FOLHAS DE UMA ÁRVORE SÃo

MUITAS, MAS A RAIZ É UMA SÓ 


\section{AS FOLHAS DE UMA ÁRVORE SÃO MUITAS, MAS A RAIZ É UMA só}

Com o Movimento de Arte Contemporânea de Moçambique, MUVART, a nova geração de artistas trouxe para a cidade de Maputo outras linguagens artísticas em que a inserção de tecnologias se fazia presente, além de novos parâmetros nessa produção. É importante considerar que a relação do cidadão moçambicano com a arte se dava pela vivência na sua própria comunidade, no contacto com os artistas locais, na grande maioria autodidatas e posteriormente no Museu Nacional de Arte, MUSART. Porém, nem sempre é fácil esta apreciação, como observa JOLLY comentando sobre a arte no Benin:

A relação das pessoas com as artes plásticas, tal como está
institucionalizada na maioria dos países, não é algo natural. Transpor o
umbral de um museu, de uma galeria, exige um esforço para vencer a
apreensão natural que se sente diante de algo que é da ordem do
sacralizado, do mistério, de um universo em geral visto como coisa
reservada para os iniciados. ${ }^{129}$

Soma-se a esta observação o fato da "novidade" do que estava sendo apresentado. A primeira Bienal em Moçambique totalizou cerca de 37 artistas incluindo representantes de diferentes países - e muitos pela primeira vez no continente africano -; sem dúvida houve um impacto para ambas as partes, tanto para os artistas moçambicanos quanto para os artistas convidados. Neste panorama a Bienal (Tabela 4) organizada pelo MUVART, que em 2010 completou sua quarta edição, já levou ao Museu Nacional de Arte e ao público moçambicano 102 artistas de países como o Brasil, Itália, França, Portugal, Espanha, entre outras nações. Apresentamos a seguir os artistas pertencentes ao MUVART, objetivando situar aspectos da contemporaneidade artística inserida neste grupo entre 2004 e 2010: Anésia Manjate, Carmen Muianga, Gemuce, Ivan Serra, Jorge Dias, Lourenço Eugenio Cossa, Marcos Bonifácio "Muthewuye”, Mondlane, Quentin Lambert, Vânia Lemos e Xavier M'Beve.

129 JOLLY,André. "A arte contemporânea e o Benin" In: África, Núcleo Interdisciplinar do Imaginário e Memória - NIME, Laboratório de Estudos do Imaginário, LABI, Instituto de Psicologia da Universidade de São Paulo, IP-USP, Ano X, n 10, 2004/2005, p.135. 


\subsection{ANÉSIA MANJATE}

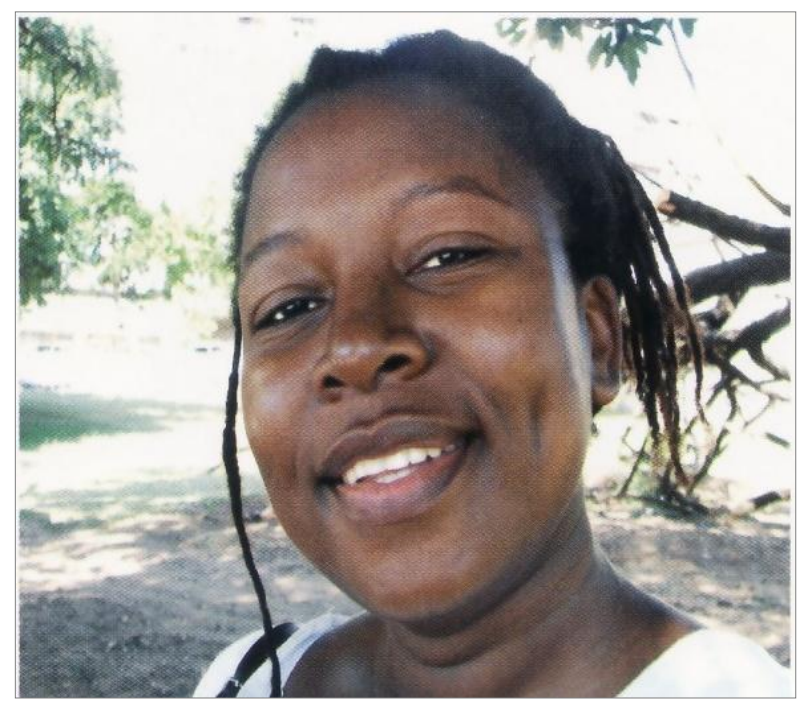

Figura 44

\section{Anésia Manjate}

Vive e trabalha em Maputo, Moçambique

Anésia Zefanias Filipe Manjate, nascida em Maputo, em 1976. Concluiu em 1997 o curso de Cerâmica da Escola Nacional de Artes Visuais, ENAV, em Maputo. Posteriormente graduou-se na Universidade Pedagógica, UP, também na capital. Exerce sua atividade profissional como artista plástica e formadora de professores na área da Educação Visual.

Anésia representa a participação feminina na cena artística maputense, expressivamente masculina. A artista vem, ao longo do tempo, construindo sua carreira tanto na formação como em uma continua jornada de exposições que se estende também para além da sua cidade natal.

Anésia é uma das fundadoras do MUVART e, como expositora atuante, integrou a Bienal Expo-Arte Contemporânea, em 2004, 2006, 2008, como se pode observar (Tabela 3).

Anésia desenvolve a maioria dos seus trabalhos na linha da instalação. $\mathrm{Na}$ crítica de arte moçambicana encontramos uma definição bastante didática para a linguagem da instalação:

Chama-se "instalação" a um novo tipo de criação artística que não é escultura, nem pintura nem desenho, mas que consiste numa ocupação temporária do espaço por objectos e matérias que constroem uma ideia. $\mathrm{O}$ espaço e as suas características ou o ambiente influenciam o artista e a instalação que faz. ${ }^{130}$

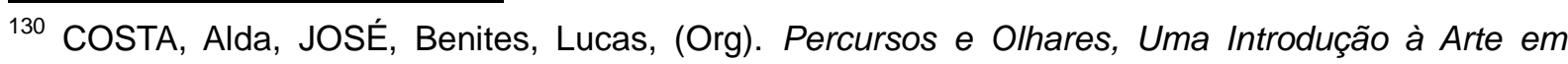


No contexto da arte moçambicana a linguagem da instalação e da performance podem representar uma novidade, necessitando de uma explicação didática para o público, porém no contexto da Europa e dos EUA estas práticas artísticas já ocorriam com mais frequência. Poderíamos somar a esta definição de instalação dada pela crítica de arte moçambicana a importância também dos happenings, a performance, entre outras ações artísticas que também constituíram a estrutura dos trabalhos de diversos artistas do MUVART. A origem da palavra instalação também pode ser associada ao artista Marcel Duchamp ${ }^{131}$ (1887-1968), além das atuações do artista alemão Kurt Schwitters ${ }^{132}$ (1887-1948) e o trabalho do francês Yves Klein ${ }^{133}$ (1928-1962).

Desde a década de 1960 podem-se encontrar em Nova lorque atuações neste sentido, depois do deslocamento do eixo cultural Europa-Estados Unidos e, claro, com a fundação de outro grupo denominado Fluxus, idealizado por George Maciunas, como um dos precursores das performances, também relacionados com as ações da Internacional Situacionista. Se considerarmos o aspecto teatral das performances poderíamos associá-los às cerimônias iniciáticas? (Ver fig.8). Para responder a esta pergunta pode-se notar que, contemporaneamente, as instalações também buscam atingir níveis sensoriais de percepção e não apenas visuais; no caso da artista moçambicana propõe-se ao público a audição de instrumentos de percussão, como os tambores. Ainda sobre o caráter das performances, GLUSBERG atesta:

As performances (ou protoperformances) geralmente nasciam de exercícios de improvisação ou de ações espontaneas. Mas havia, ao mesmo tempo, uma incorporação das técnicas do teatro, da mímica, da dança, da fotografia, da múscia e do cinema ( que era, nessa época, uma nova mídia -os irmãos Louis e Auguste Lumiére tinham apresentado seu invento no fim de dezembro de 1895). ${ }^{134}$

Ante o exposto, quais são os elos que ligam o passado, a arte dita tradicional, com o contemporâneo, a arte produzida hoje? Em todos os artistas do MUVART encontraremos estas ressonâncias?

Moçambique, EPM-CELP, 2008, p.92.

131 Ready-mades.

132 As montagens "Merz" título dos trabalhos do artista Kurt Schwitters.

133 Exposição em Paris, $A$ especialização da sensibilidade no estado de matéria-prima em sensibilidade pictórica estabilizada, O vazio (1958).

134 GLUSBERG, Jorge. A Arte da Performance. Perspectiva: São Paulo, p.12. 
Outra questão que se coloca para o mercado de arte e para o artista é como negociar e expor estes trabalhos inscritos na linguagem da instalação e até mesmo da performance como no caso dos trabalhos de Anésia Manjate.

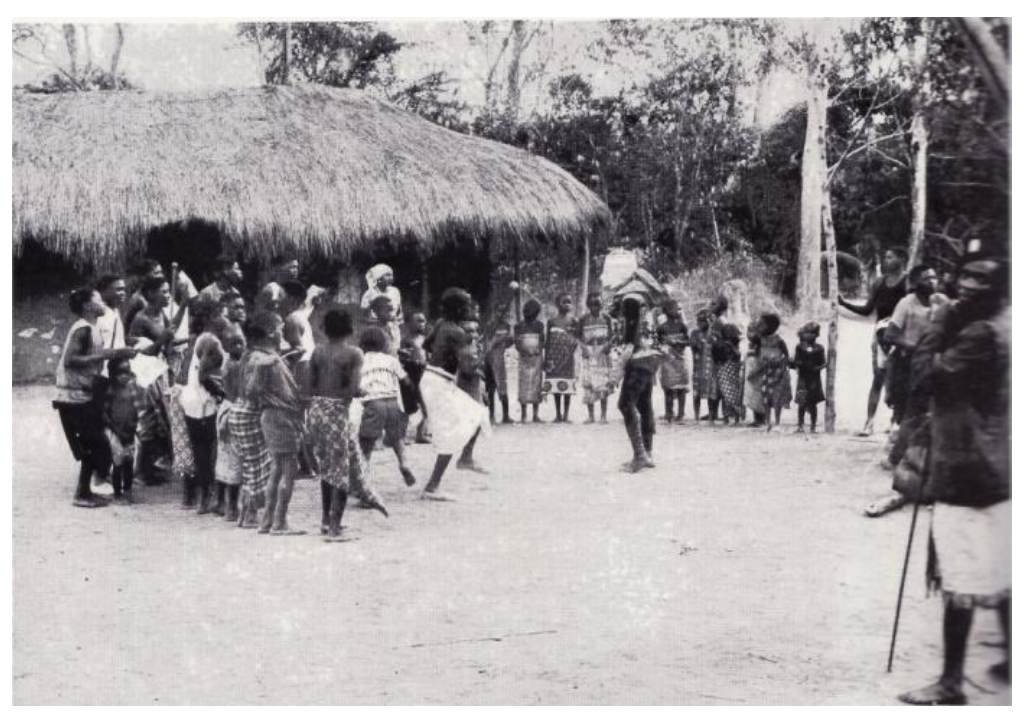

Figura 8 - Dança do mapiko na pequena povoação de Impueba,

Estas novas linguagens artísticas e outras iriam encontrar um mercado de arte ainda voltado para as demandas das belas-artes. Apesar de o estudo de PINHO centralizar-se na técnica da pintura, destacamos sua análise econômica que acena com uma origem e atesta uma realidade que vai se concretizando ao longo da história em relação à obra e ao artista:

\footnotetext{
As principais origens históricas do mercado de pintura podem ser encontradas na França, na segunda metade do século XIX, a partir de sério conflito de interesses entre a burocratizada Academia de Belas-Artes de Paris (instituída oficialmente por Colbert, em 1648) e o Romantismo, que buscava um novo papel social para o artista. ${ }^{135}$
}

Esse papel social, frisado por PINHO e que constitui a produção de muitos artistas, no caso de Anésia irá transitar na cultura moçambicana e no lugar que a mulher ocupa na sociedade.

Em entrevista concedida em julho de 2010, a artista afirma: "Eu lembro sempre que na minha família sentávamos em uma esteira e conversávamos, morávamos juntos, a minha família é grande." Com esta experiência individual e pertencente ao grupo familiar, a artista vai compondo um universo estético, com as

135 PINHO, Diva Benevides. A Arte Como Investimento, A Dimensão Econômica da Pintura. São Paulo: Nobel, 1988, p.41. 
panelas de barro, os sapatos, os fios, as lâmpadas ocupando outros espaços, no qual a artista opta pelas linguagens da instalação, quando de sua primeira participação na amostra do MUVART, em 2004, assim como da performance e menos usualmente na própria pintura agregando à tela elementos em terceira dimensão. Anésia integrou em 2004 a Coletiva Expo-Arte Contemporânea, no Museu Nacional de Arte, MUSART, em Maputo, que foi, como dissemos, a primeira Bienal organizada pelo Grupo MUVART - com um trabalho intitulado "Influência da Tradição na Contemporaneidade”, como podemos observar na Fig. 45; no catálogo desta exposição pode-se ler o depoimento da artista:

É meu objetivo com este trabalho dar a conhecer a influência que a tradição
pode exercer na arte contemporânea, no intuito de criar um momento de
reflexão sobre a cultura local. Através de formas tridimensionais, situações
de som e movimento, pretendo que o observador interaja com a obra, e que
o seu comportamento seja invariavelmente alterado quando exposto a sons
e texturas espalhadas pelo chão. Ao som do cantar das curandeiras, do
rugir das feras, cantos dos pássaros, o som do tambor e das folhas secas
quando pisadas, o espectador será envolto em referências culturais que
questionarão a sua percepção do tradicional num espaço de exposição
contemporâneo. ${ }^{136}$

Através da descrição do seu trabalho fica clara a proposta da artista: a utilização de materiais naturais e um sistema de código cultural local. Este trabalho inscreve-se na matriz da instalação; o que observamos na Fig. 45 é apenas um detalhe.

Os elementos que compõem a obra como percebemos são todos diretamente ligados à raiz africana, mesclados com outros elementos que fazem a ponte entre o tradicional e o contemporâneo, respectivamente: esteiras, peneiras, tambor, folhas secas; posteriormente: aparelho de som, arame. O título do trabalho também é claro neste sentido, não restando dúvidas para o espectador.

O espaço onde a obra se encontra exposta é o museu, concebido como lugar de contemplação; a contemporaneidade traz embutida também a noção do evento e do espetáculo, como já antecipava DEBORD.

${ }^{136}$ Expo-Arte Contemporânea, Maputo, Moçambique, catálogo da mostra, 2004, p.29. 


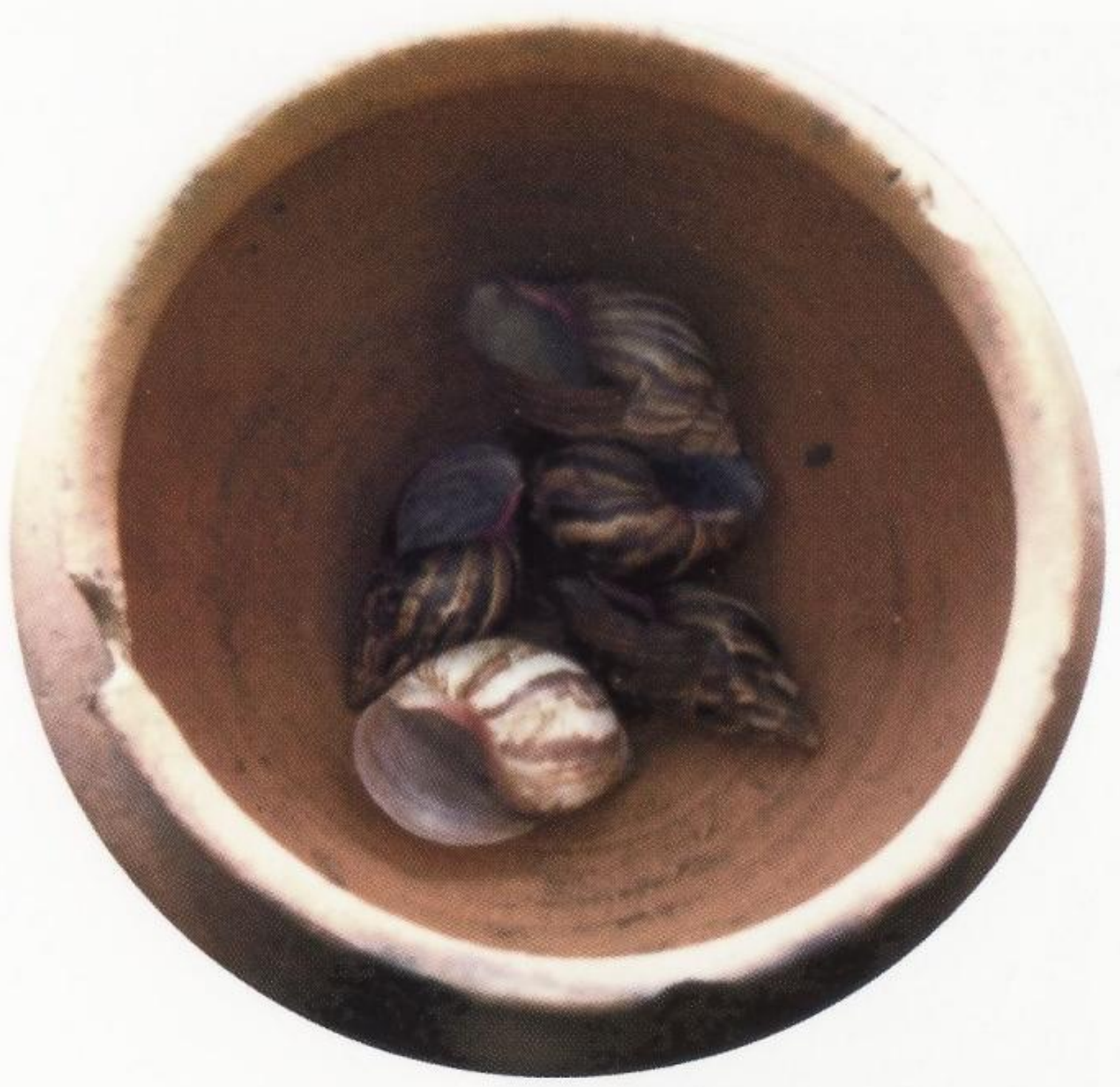

Figura 45 Anésia Manjate

Influência da Tradição na Contemporaneidade (pormenor)

Esteiras, peneiras, tambor, folhas secas, aparelho de som, arame

Dimensões variáveis 
Em 2006, Anésia Manjate faz sua segunda participação na Coletiva Expo-Arte Contemporânea, organizada pelo MUVART no Museu Nacional de Arte, MUSART, em Moçambique, desta vez com o trabalho Laços. Trata-se também de uma instalação, a qual serve de capa para o catálogo. Na figura 45 podemos observar um detalhe da obra. Este trabalho é uma instalação em que todas as panelas estão ligadas e dispostas em forma circular.

Algumas características ao longo do tempo apresentam-se na produção da artista; a figura circular é recorrente neste caso, na sua segunda participação, e, como veremos a seguir, na terceira.

As instalações estão sempre dispostas no interior do museu em forma circular; o fato levou-nos a refletir sobre esta forma. FRUTIGER, autor com ampla pesquisa sobre sinais e símbolos, em face desta forma geométrica, escreve:

Tomando o círculo como ponto de partida, o observador encontra a linha com retorno eterno: ela não tem nem começo nem fim e circunda um centro invisível, porém muito preciso. É do curso do tempo, que não vem de nenhum lugar e não tem fim. Para os primitivos, o círculo certamente tinha uma grande importância simbólica, devido à associação com o Sol, a Lua e as estrelas. ${ }^{138}$

Evidentemente, o autor faz comparações com a ideia do símbolo circular para o homem contemporâneo e parece-nos pertinente no caso da artista moçambicana.

Em entrevista, a artista comenta que estas panelas foram cedidas por diversos amigos. Neste caso, a ideia é construir um trabalho que tem no seu processo uma história, e este requisito perpassa pelas discussões da arte contemporânea, ou seja, a obra não é apenas o que está sendo exposto mas também o que a antecede.

${ }^{138}$ FRUTIGER, Adrian. Sinais e Símbolos. Martins Fontes: São Paulo, 2001, p.11. 


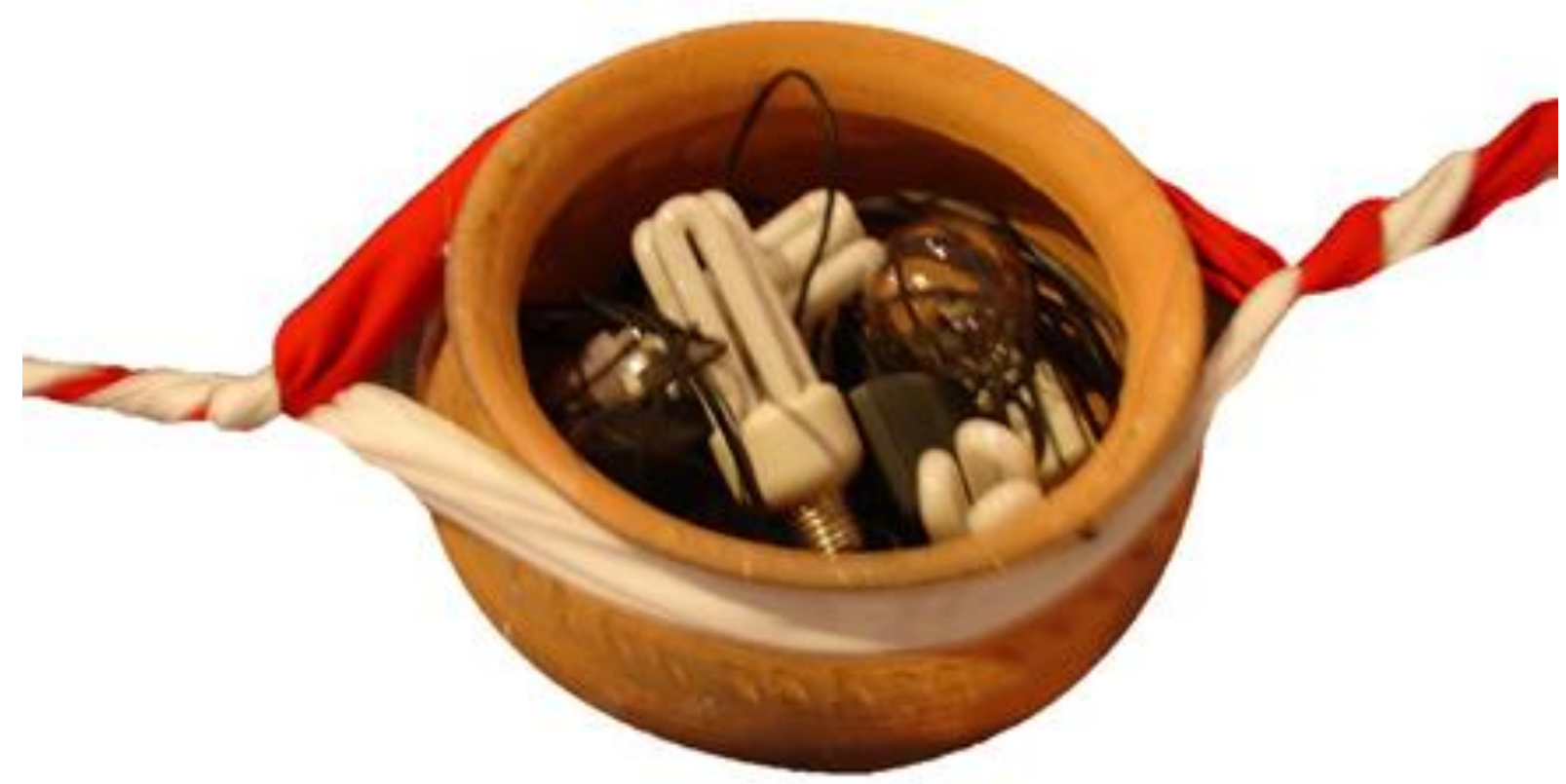

Figura 46 Anésia Manjate Laços

lâmpadas, panos, fios, calculadora.

Dimensões variáveis.

A forma circular está presente em praticamente todos os assentamentos humanos no continente africano, como também está a utilização da própria cerâmica no dia a dia da comunidade. Como se ensaia no quadro comparativo entre os Macondes, Macuas e o trabalho da artista (Fig. 47).

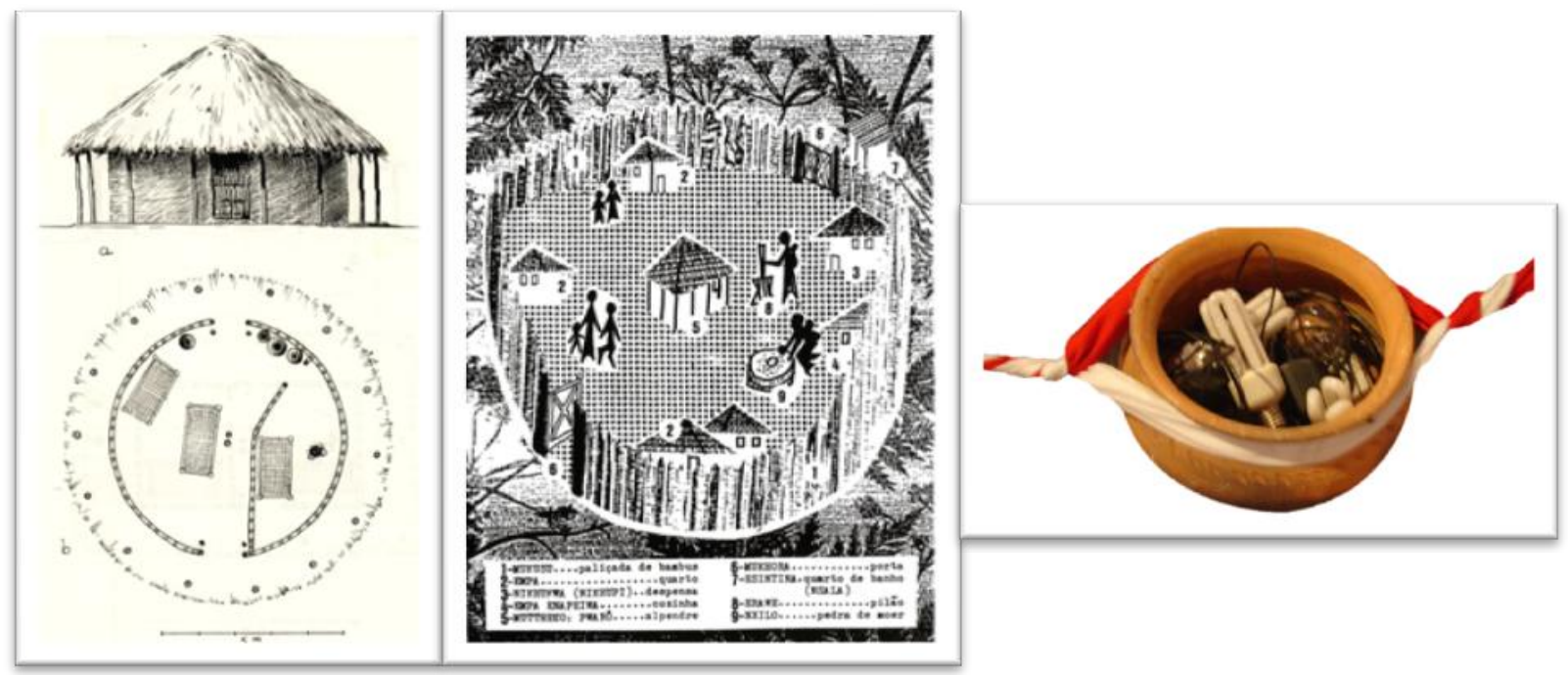

Figura 47 Quadro comparativo entre Macondes, Macuas e o trabalho de Anésia Manjate.

Planta de uma casa circular dividida em dois compartimentos e o telhado apoiado em pilares.

"Ettoko", residência macua.

Anésia Manjate Laços, lâmpadas, fios.

Dimensões variáveis 
Todos os elementos que compõem a obra de um artista devem ser levados em consideração quando da sua análise, que é a chave para o encontro da obra com o coletivo. No caso de Anésia a compreensão da cultura moçambicana torna-se fundamental. Sobre este trabalho MANJATE comenta;

O laço é mais um tema tratado por mim ligado a influência da tradição na
contemporaneidade, onde busco elementos ligados a tradição e
tecnologias...Para tratar das influencias e da confrontação da diversidade
cultural onde cada individuo da família exerce influencia através da sua
experiência na formação de um novo individuo, pela tradição, tecnologias
sem esquecer as suas raízes.... o círculo representa união, conselho e
consenso que gera laços de família e de sangue onde a panela (...)
representa a raiz, a base para o individuo crescer; o pano branco representa
a ligação, a paz familiar; o pano vermelho, a ligação consanguínea; os fios,
as máquinas de calcular, espelhos, telemóveis, representam as tecnologias;
as folhas e as raízes, a ligação com a medicina tradicional...

Este questionamento trazido pela artista exemplifica como se vai produzindo a obra pictórica, ao mesmo tempo ampliando o espaço de compreensão e permanência da cultura nacional.

Há uma discussão intrínseca nas produções artísticas de Anésia: o papel da mulher e sua posição na sociedade, e neste sentido expandindo-se também para o contexto do mundo globalizado, onde a situação de subjugação persiste em diferentes níveis.

A última participação de Anésia Manjate na Expo-Arte Contemporânea foi em 2008, dentro do contexto do MUVART, e realizou-se mais uma vez no Museu Nacional de Arte, MUSART, em Maputo. Com o trabalho intitulado Experiência, desta vez uma instalação cujo único material foram sapatos de crianças, a artista totalizou três participações nas Bienais do MUVART.

Usando um objeto pessoal, de uma vivência privada, a obra pretende ser elevada ao status de arte quando justamente atinge o seu grau de universalidade. Esta foi sempre a intenção de todo artista: poder falar a muitos.

Nesse ponto vale lembrar que a cerâmica tem sido protagonista e base para a construção das instalações, e faz parte da formação de Anésia. Neste momento a artista rompe com esse material e dá-nos outro campo de possibilidade poética na figura 37 (detalhe) da obra exposta no MUSART.

${ }^{139}$ Expo-Arte Contemporânea, Maputo, Moçambique, catálogo da mostra, 2006, p.17. 


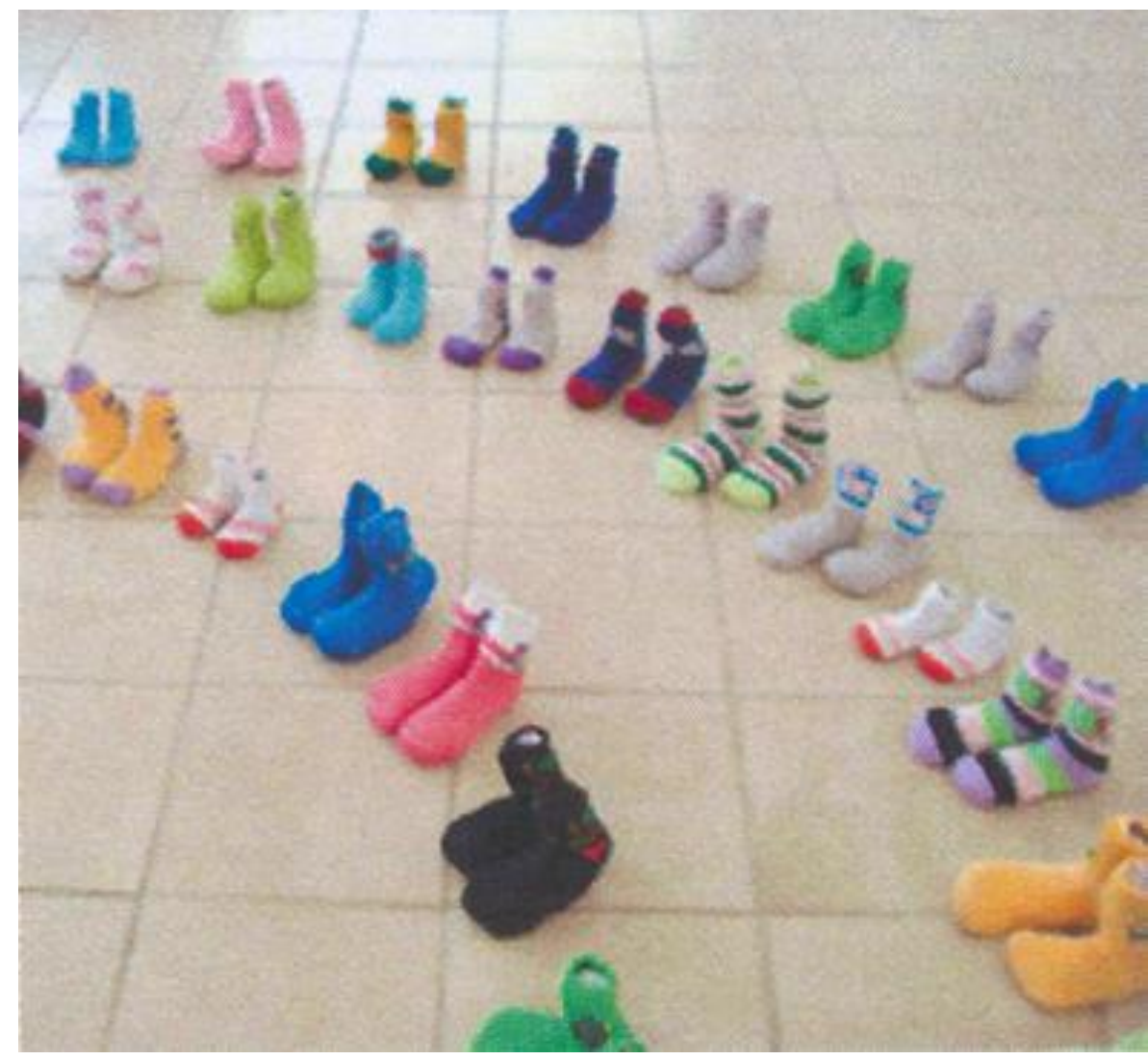

Figura 48 Experiência

Sapatos de lã

Dimensões variáveis

2008

Nesta edição de 2008, intitulada Toca do Rato, a curadoria lança um desafio que a diferencia das anteriores e abre caminho a outras abordagens. DIAS escreve:

O Movimento de Arte Contemporânea de Moçambique (Muvart) propõe para esta exposição, artistas com diferentes abordagens e de diferentes modos de estar na arte...Por não partilharmos uma política castradora de liberdade de expressão e de criação, partilhamos uma liberdade criadora com escolhas e posicionamentos diferenciados. Esta mostra pretende assim abrir um debate, através de cruzamentos possíveis de posicionamentos dos artistas neste país.

Foi com "Primeira Pedra", em 2004 que o Muvart iniciou este caminho. Em 2006 demos "Mais um Passo" para a contemporaneidade em Moçambique e, neste ano de 2008, na "Toca do Rato" gerimos políticas traçadas desde a nossa criação... ${ }^{140}$

A concepção desta mostra tem como critério principal discutir a produção artística e suas distintas linguagens, dar voz, rosto e lugar ao artista, sem atrelar juízos de valores e pertencimentos.

140 DIAS, Jorge (curador). Expo-Arte Contemporânea, Maputo, Moçambique, catálogo da mostra, 2008, s/p 
Toda a narrativa que a artista Anésia Manjate vem construindo na sua carreira artística tem o repertório interligado à cultura tradicional moçambicana e torna-se importante relacioná-lo aos grupos étnicos aqui apresentados, com exceção da cultura Changana da qual não obtivemos material. Contudo, a obra da artista, potencializando os valores da cultura nacional e local, traz à baila estes elementos em suas instalações, os quais, sendo considerados similares a outros grupos étnicos, como no caso da arquitetura dos Macondes e Macuas, tanto quanto as peças utilitárias produzidas em barro, nos proporcionam uma compreensão maior da sua estética. 


\subsection{CARMEN MUIANGA}

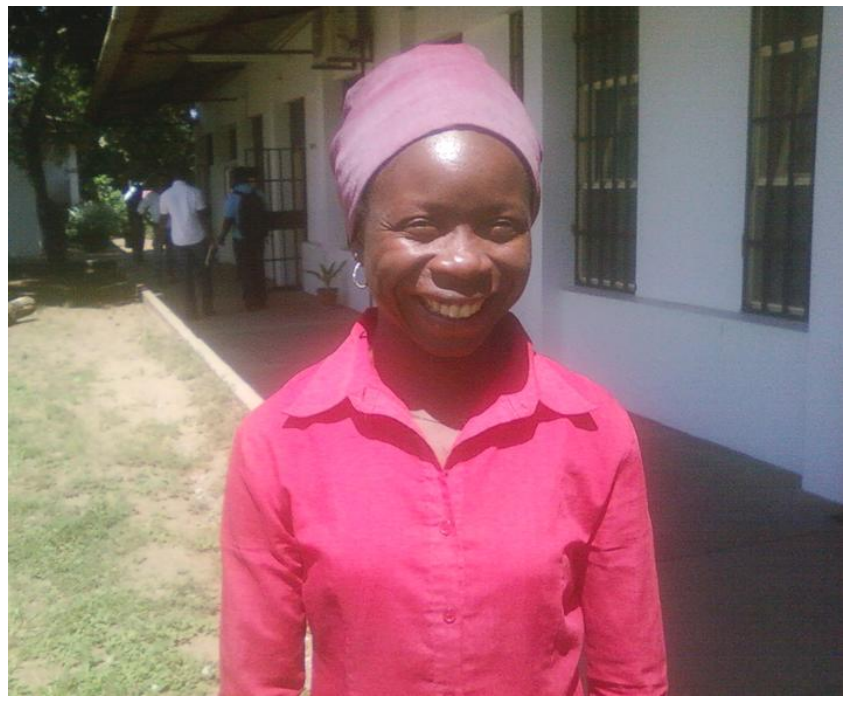

Figura 49

\section{Carmen Muianga}

Vive e trabalha em Maputo, Moçambique

Carmen Maria Muianga, nascida em 1974, ainda quando Maputo se chamava Lourenço Marques. A artista vive e trabalha na capital. Concluiu na Escola Nacional de Artes Visuais o curso de Gravura, e posteriormente, o curso de Gráfica, na Escola Nacional de Artes Visuais, em Cuba. Atualmente completa sua formação matriculada no curso de design do Instituto Superior de Artes e Cultura, ISArC, primeira instituição voltada para o ensino superior em Artes em Moçambique. É membro do Núcleo de Arte em Maputo e membro fundadora do Movimento de Arte Contemporânea de Moçambique, MUVART.

Integrou a primeira Bienal Expo-Arte Contemporânea, organizada pelo MUVART, edição de 2004. Trabalha com uma técnica de gravura denominada Colagrafia $^{141:}$

... Esta técnica segundo a artista permite "acrescentar" e criar uma superfície complexa para a gravura. Utiliza-se um cartão espesso e forte (a matriz) onde se vão "acrescentando" diferentes camadas de papel sem cola, previamente tratado, e onde se cria a composição desejada. Aplicam-se

${ }^{141}$ Antes do Renascimento, os artistas não costumavam assinar suas produções. O comércio de gravuras através de bulas papais, ou a venda de santos nas feiras e festas religiosas, se acentuaram no final do século XIV. No século XV, com as impressões sobre papel, eram raros os artistas que assinavam. O monograma ou a simbologia adotada identificava o artista, numa época em que na Itália, na França e na Alemanha começaram a pontificar os editores. No século seguinte, acrescida dos colecionadores, a gravura eleva seu prestígio que se acentua sobremaneira no século XVII. Apud MARTINS, Itajahi. Gravura: arte e técnica, São Paulo: Laserprint:Fundação Nestlé de Cultura, 1987, p.24. 
depois as tintas de impressão escolhidas e a superfície fica pronta para receber o papel da impressão. Segue-se a passagem pela máquina de impressão. ${ }^{142}$

A artista envereda em experiências estéticas que têm como técnica a gravura, porém incorpora outros elementos gráficos como descritos pela própria artista.

Voltando um pouco atrás, em 1999 Carmen trabalha com Pintura, sendo inclusive premiada nesta categoria onde obteve $02^{\circ}$ Prêmio na Exposição denominada Reconstrução, em Maputo.

Anteriormente à criação do Movimento de Arte Contemporânea de Moçambique, MUVART, diversos artistas do próprio grupo dão seus primeiros passos nas Bienais promovidas pela Empresa Telecomunicações de Moçambique, TDM ${ }^{143}$; já em 2003 a artista ganha o 1ํ Prêmio em Gravura nesse evento.

Esta Bienal já revelou muitos artistas hoje consagrados no cenário local e internacional. Atestando sua importância, CARVALHO observa:

A organização da 10ª edição da Bienal TDM 2009, reflecte o resultado das reflexões e contribuições oportunas vindas de vários quadrantes do universo artístico e cultural produzidas ao longo das sessões paralelas de debates e palestras a quando da realização da Bienal TDM 2007...quisemos inaugurar um novo ciclo de bienais, caracterizado pela introdução paulatina de algumas inovações organizacionais, na perspectiva de tornar o evento mais aberto, aliciante e que incorpore novas percepções e manifestações da nossa criação artística contemporânea... "Espaços de Hoje: Desafios e Limites", é bem exemplo dessa tentativa, na esteira do qual os olhares peculiares dos nossos artistas procuram com cores e formas, reflectir e expressar com todos os simbolismos estéticos algumas inquietações e anseios vivenciados do nosso quotidiano. ${ }^{144}$

${ }^{142}$ COSTA, Alda, JOSÉ, Benites, Lucas, (Org). Percursos e Olhares, Uma Introdução à Arte em Moçambique, EPM-CELP, 2008, p.96.

143 Bienal organizada pela Empresa Telecomunicações de Moçambique (TDM) é uma mostra tradicional no circuito das artes em Moçambique. É um concurso público aberto a nacionais e estrangeiros, com o apoio do Museu Nacional de Arte, MUSART, e ocorre em geral no segundo semestre do ano. Prevê a premiação dos participantes, estipulando $1^{\circ}, 2^{\circ}$ e $3^{\circ}$ lugares mais as menções honrosas que o júri considerar. São previstas também pela comissão organizadora homenagens a artistas indicados pelos jurados.

144 CARVALHO, Joaquim Ribeiro, Presidente do Conselho de Administração da Empresa Telecomunicações de Moçambique. Espaços de Hoje: Desafios e Limites, Maputo, Moçambique, catálogo da mostra, 2009, p.2. 
Havia, portanto, veredas abertas no sentido de renovação no cenário artístico com a organização e inserção de novas discussões e artistas em Maputo. Com doze anos de profissão, Carmen Muianga vai se dedicando à gravura. Linguagem tradicional, nesta obra exposta na Bienal Expo-Arte Contemporânea, em 2004, na qual a matriz é trabalhada, ou seja costurada e montada, existe uma limitação em sua numeração e tiragem, com a interferência manual da gravadora "retrabalhando" a matriz. Cada peça passa a ser única, o que se contrapõe à função clássica da gravura que é sua reprodutividade. Neste processo é preciso definir então o número total de exemplares e isso ser marcado no suporte final.

Figura 50

Carmen Muianga Poemas llustrados Técnica mista.

Dimensões variáveis 2004

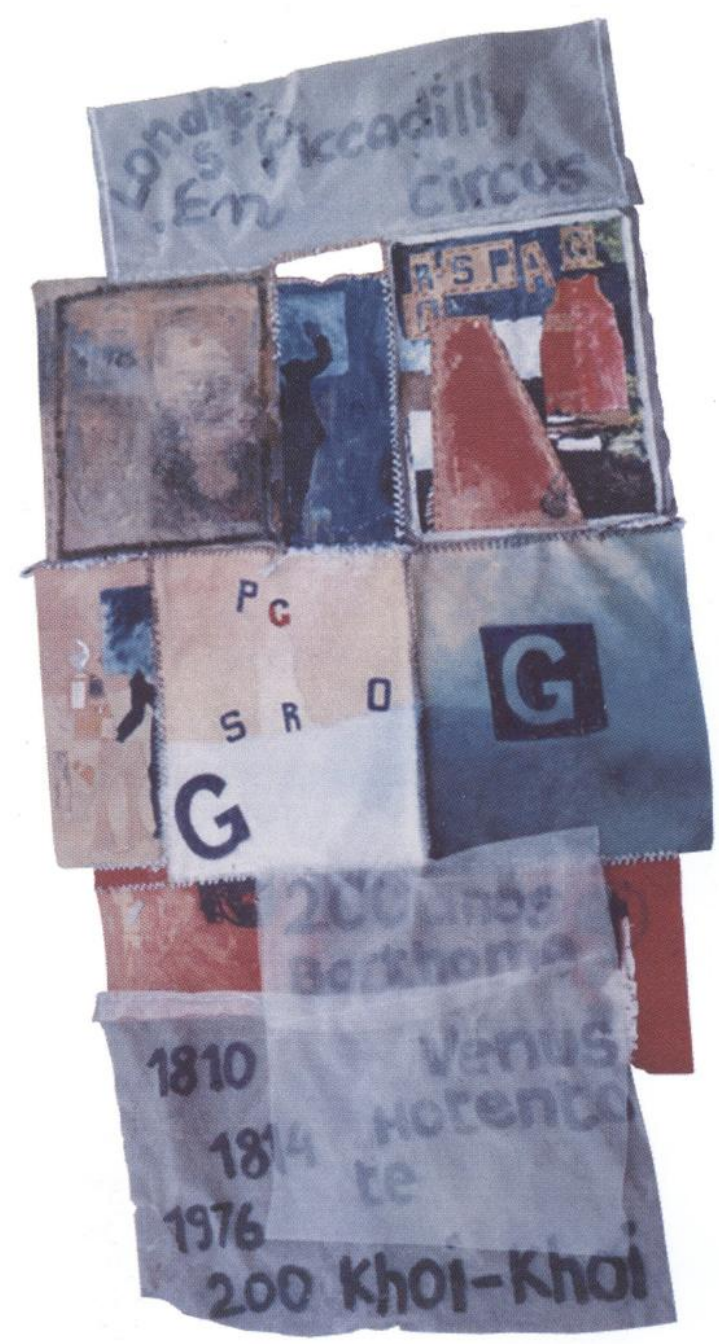


Neste trabalho, Poemas Ilustrados, 2004, Carmen enfatiza a sua proposta:

Faço uma interpretação multifacetada bidimensional de uma série de poemas por mim escolhidos. As referências directas aos poemas são escassas ou quase inexistentes, reduzidas a simples letras, fazendo transparecer sensações subjectivas em detrimento de uma abordagem explícita. Numa relação em que se equilibram texturas quase orgânicas e cores fortes, diferentes secções são cosidas e coladas umas às outras usando linhas estéticas e cores fortes, diferentes secções são cosidas e coladas umas às outras usando linhas estéticas diferentes e criando harmonia visual. ${ }^{145}$

Como se pode observar (Fig. 50), não existe nenhuma indicação de que se trata de uma série; ao contrário, ao optar pela técnica mista, insere a técnica da gravura no processo, sem relação direta com o seu fim. A apropriação de diversas técnicas é outro questionamento presente na arte contemporânea.

Diferentemente de Anésia Manjate, sua linguagem está mais relacionada ao domínio da técnica da gravura e ao exercício constante que faz dela como expressão visual, aplicando cor, desenhos e diversos materiais. Não se pode dizer e nem a artista afirma - que neste caso existe uma ligação direta com a arte tradicional moçambicana. O seu universo insere-se mais no viés psicológico, da memória e do recorte.

A inscrição que a artista faz neste trabalho é mais de cunho pessoal, o que se percebe no resultado posterior da obra. Estes fragmentos textuais dão ao trabalho final apenas a visualidade gráfica pretendida pela gravadora, uma vez que as letras aqui funcionam como símbolos gráficos e não como parte integrante de um corpo textual; trata-se neste caso de habitar um corpo visual e estético, assim como as cores.

Em entrevista concedida em julho de 2010, a artista afirma: "Eu aprendi, e vi muitas coisas quando estive em Cuba"; no que se refere ao domínio e à experimentação da técnica da gravura, esse aprendizado é notável em cada passagem por seus trabalhos.

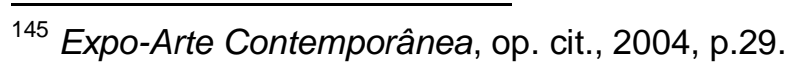




\subsection{GEMUCE}

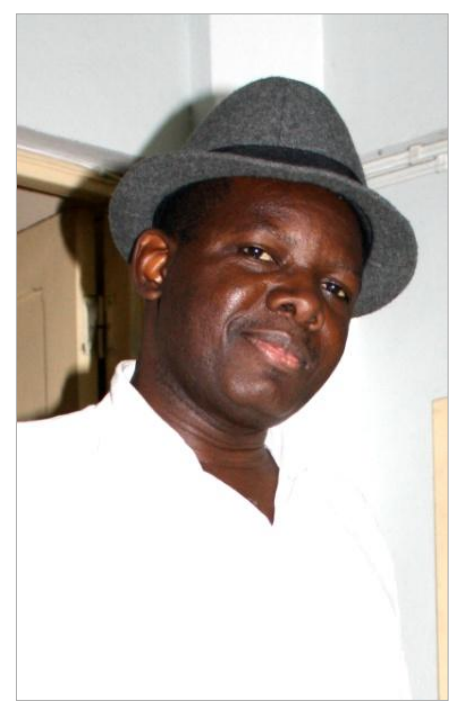

Figura 51

\section{Gemuce}

Vive e trabalha em Maputo, Moçambique

Gemuce, (Pompílio Hilário), natural de Quelimane e nascido em 1963, é formado em Cerâmica na Escola Nacional de Artes Visuais, ENAV, em Maputo, onde é docente desde 1994. Gradua-se em Belas-Artes, pelo Instituto de BelasArtes de Kiev, Ucrânia, em 1990. É Mestre em Pintura de Murais pela Academia de Belas-Artes de Kiev, Ucrânia, e, em 2001, em Concepção, Decisão e Gestão de Projetos Culturais pela Universidade FCP3 Sorbonne Nouvelle, França.

É membro fundador e presidente do Movimento de Arte Contemporânea de Moçambique, MUVART. Participou de quatro edições das Bienais Expo-Arte Contemporânea organizadas pelo MUVART, ou seja, desde a sua primeira edição até a última, compreendendo o período de 2004 a 2010.

Gemuce transita nas linguagens da pintura, escultura, instalação, fotografia e vídeo. No trabalho do artista nota-se a ligação com a arte tradicional moçambicana com um viés analítico e crítico.

Neste sentido, participou em 2004 da Coletiva Expo-Arte Contemporânea, no Museu Nacional de Arte, MUSART, em Maputo, a primeira Bienal organizada pelo Grupo MUVART, com um trabalho intitulado 3 Momentos, 2004 (Fig. 52).

O artista escreve no catálogo da exposição:

É delicadamente composto neste vídeo-objecto, um pormenor do acto de uma jovem estudante concentrada na leitura. Ao longo da leitura, a jovem faz duas pausas para comunicar gestualmente com o espectador do exterior de uma janela. Os seus gestos, um sorriso, um piscar de olhos, os 
pormenores da pele negra, o lenço na cabeça, a voz típica, o eco da casa, a mesa com toalha, são elementos naturalmente integrados para retratar uma cena quotidiana. Este vídeo é explorado de modo a possibilitar uma composição seguindo os princípios de uma pintura clássica, onde aproveito a luz natural do sol de África, para conseguir cores quentes e contrastes entre figura-fundo. ${ }^{146}$

A explicação do artista sobre a intenção do seu trabalho trás o discurso da pintura aliada à tecnologia do vídeo, a leitura realizada pela jovem tem o conteúdo ocidental, mais precisamente a história da Europa e ironicamente é o que se estudava nas escolas moçambicanas.
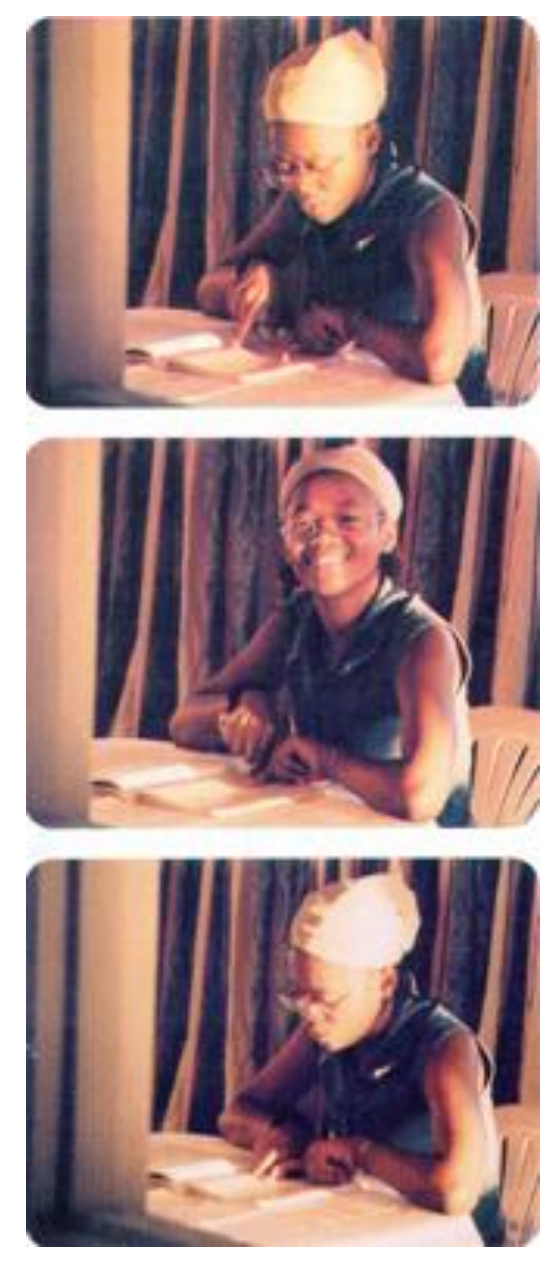

Figura 52

3 Momentos (detalhe)

Videoinstalação

Chapas de zinco e projeção de vídeo no televisor.

Dimensões variáveis

2004

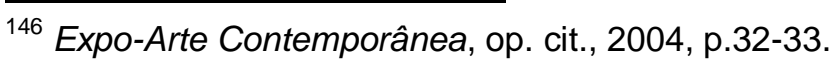


Gemuce comenta ainda sobre este trabalho:

3 momentos : O presente, o real e o imaginado Gemuce $^{147}$

Neste vídeo-objecto, vê se uma jovem estudante concentrada numa leitura sobre a História da Europa. A composição da imagem da jovem numa abertura pequena de uma parede feita de chapas de zinco é visualizado através da técnica de vídeo projetada num ecran de um televisor. O acto ilustra uma cena quotidiana do meio rural na sociedade Moçambicana: Casa em condição precária, sem energia electrica. A estudante com visão deficiente aproveita a luz do sol para concluir a sua leitura enquanto ao mesmo tempo procura interagir com o telespectador através de um olhar, sorriso sedutor e ingênuo de ter o "Ocidente" a sua janela.

Este vídeo faz parte de uma instalação ${ }^{148}$ montada em chapas de zinco, como explica o artista. Traçando uma relação paralela, situação semelhante ocorre no Brasil como denuncia ZAMPARONI:

Qualquer brasileiro que tenha passado pelo primeiro grau certamente já ouviu falar das cidades-estados gregas, do Império Romano, do Sacro Império Romano-Germânico, das potências aliadas; de Alexandre, Nero, dos vários Luizes, Napoleão, Churchill, Roosevelt, Hitler ou Stalin, mas quem já ouviu falar dos Ashantis, lorubás, Haussás, Fulas, Bakongos, Makondes, Xhosas, Macuas e Swahílis? E do império do Monomotapa, dos reinos do Daomé, do império Vátua, da Rainha Jinga, de Mussa Keita, de Sundjata, de Chaka e Ngungunhane, Amílcar Cabral, Patrice Lumumba, Julius Nyerere ou Samora Machel? Alguém já estudou a respeito? O que se sabe sobre esses nomes senão algumas palavras superficiais? ${ }^{149}$

A conjugação de elementos plásticos da pintura com o uso da tecnologia, particularmente o vídeo, é característica de uma proposta artística que na contemporaneidade não exime a obra de carregar um conteúdo crítico e político, o qual depende apenas da sensibilidade do artista tanto quanto ZAMPARONI o faz enquanto pesquisador.

Em 2006, Gemuce apresenta-se na Coletiva Expo-Arte Contemporânea, organizada pelo MUVART no Museu Nacional de Arte, MUSART, em Moçambique, desta vez com o trabalho A Globalização na Faixa de Rodagem, videoinstalação, 2006 (Fig. 53).

147 Depoimento do artista à autora, via e-mail, abril.2011.

148 Trabalho visto montado pela pesquisadora na edição de 2004

149 ZAMPARONI. Valdemir. A África e os estudos africanos no Brasil: Passado e Futuro. Disponível em: http://www.nacaomestica.org/zamparoni a africa e os estudos africanos.htm Acessado em: 28 agosto 2010. 

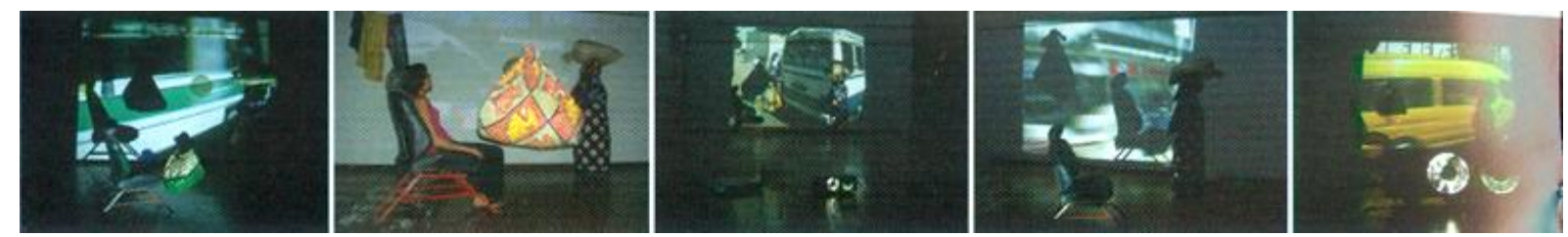

Figura 53 A Globalização na Faixa de Rodagem

Videoinstalação

Dimensões Variáveis, 2006

Sobre seu trabalho o artista comenta;

Coloco para esta abordagem, o meu acto criativo como atitude de improvisação "consciente" confrontando-a com atitudes de improvisação, por necessidade...Não são as causas dos improvisos que me interessam, nem análises científicas, políticas, econômicas, etc.... Interessa-me é apresentar resultados de improvisação, obtidos e captados por uma observação superficial onde as paisagens, as melodias e as cenas...denunciam a globalização... fazendo de todos consumidores de tudo! Uso simbolicamente nesta abordagem, o meio de transporte colectivo conhecido popularmente por "chapa 100 "... O surgimento do "chapa 100" em Maputo nos anos 80 , é afinal também resultado de um improviso e, coincide com o início de uma nova etapa sócio-econômico, político e cultural ligada à questão da globalização em Moçambique... ${ }^{150}$

Dando prosseguimento a sua pesquisa dentro da linguagem do vídeo, Gemuce mais uma vez expõe seu ponto de vista como artista e como cidadão moçambicano. Nesta videoinstalação a interação é maior, o espectador é convidado a sentar-se e praticamente integra-se às imagens, ao contrário do trabalho exposto na Bienal de 2004, na qual o público tinha uma relação mais contemplativa.

$\mathrm{Na}$ Expo-Arte Contemporânea, edição de 2008, dentro do contexto do MUVART, que também se realizou no Museu Nacional de Arte, MUSART em Maputo. Uma das fotografias do artista, Ciclo vicioso, 2008, que serviu de capa ao catálogo (Fig. 54), é uma série de 13 fotografias em cores.

${ }^{150}$ Expo-Arte Contemporânea, op. cit., 2006, p.22. 


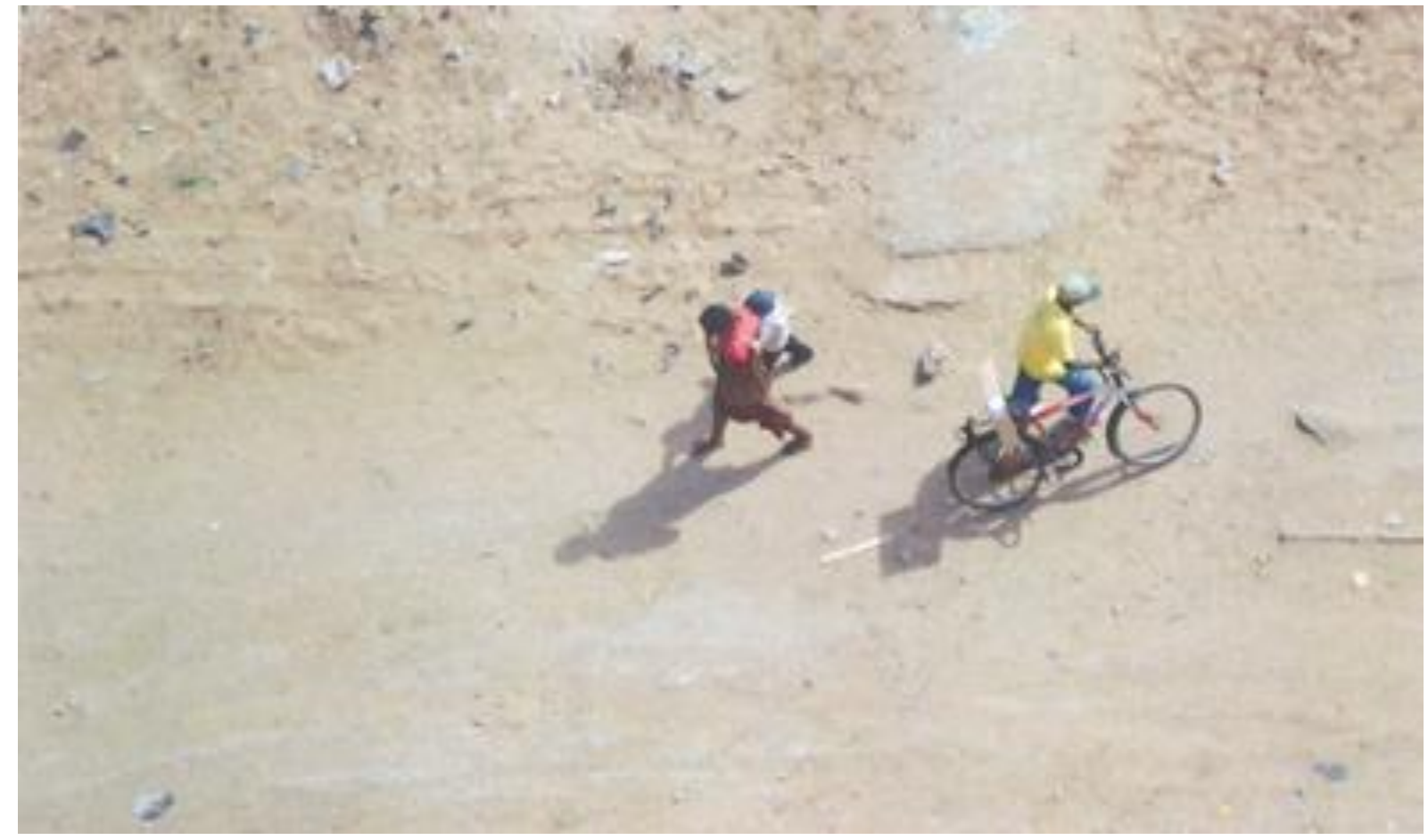

Figura 54 Ciclo Vicioso

Fotografia

Dimensões variáveis, 2008

Três fotografias que não constam do catálogo nos dão a ideia da série (Figs. 55, 56 e 57). Via e-mail, o artista explica seu processo de criação:

Eu participei com um seriado de 13 fotos. Estas 3 são suficientes para ilustrar. Posicionei a minha máquina do $11^{\circ}$ andar num ponto fixo e fotografei todos que passaram por aquele ponto. Chamei este trabalho de "ciclo vicioso".
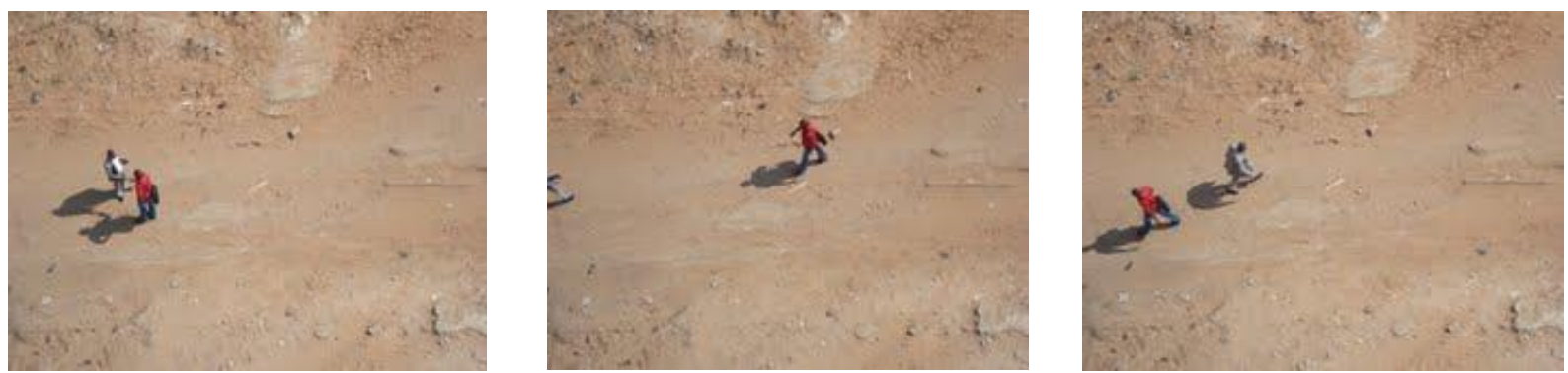

Figuras 55, 56 e 57 Ciclo Vicioso

Fotografia, 2008

Acervo do artista 
A última Expo-Arte Contemporânea realizou-se no Museu Nacional de Arte, MUSART, em Maputo. Em 2010, Gemuce apresentou o trabalho intitulado Corrida Preconceituosa, 2010, uma instalação. Integrante do grupo MUVART, que tem mais participações nesta mostra, o artista apresenta em cada Bienal uma discussão nova, atento à realidade do país. Sua obra vai consolidando-se ao longo do tempo.

Nesta exposição, somaram-se artistas de diferentes formações trazendo propostas artísticas, tais como a arte pública, a performance, a instalação, o vídeo, entre outras manifestações.

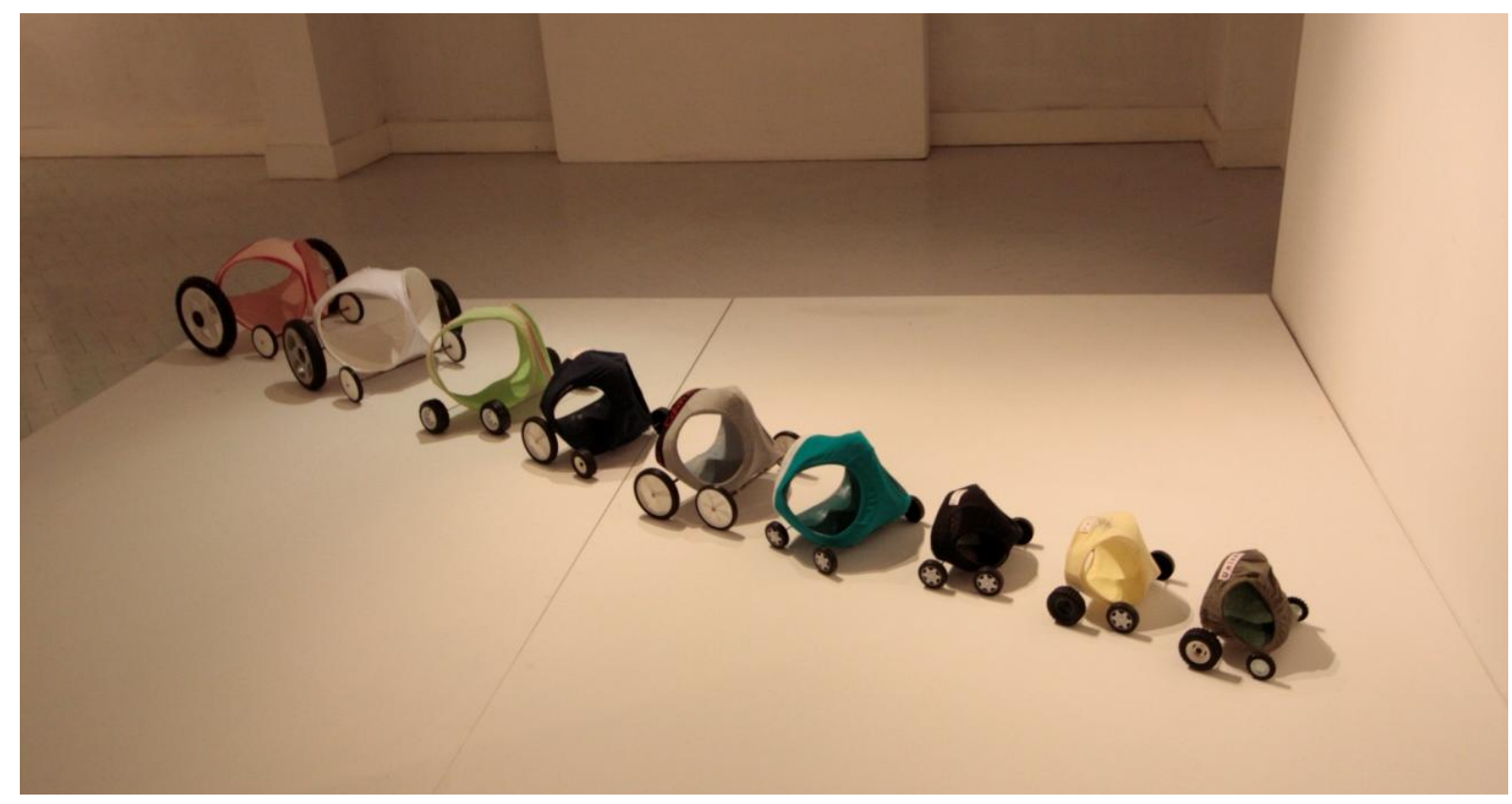

Figura 58 Corrida Preconceituosa

Peças íntimas, rodinhas de plástico e armação de arame recoberto 2010

A crítica ideológica posta por Gemuce permeia toda a sua obra; poderíamos enquadrá-la na arte dita "engajada" que também marcou a geração de Malangatana, Reinata Sadimba e Victor Sousa.

Atento à realidade moçambicana, Gemuce realiza uma crônica visual, porém seu intuito não está atrelado a uma transmissão de valores morais, é uma atitude reflexiva sobre o mundo, como artista, ao público cabendo a missão de ler nas entrelinhas. 


\subsection{IVAN SERRA}

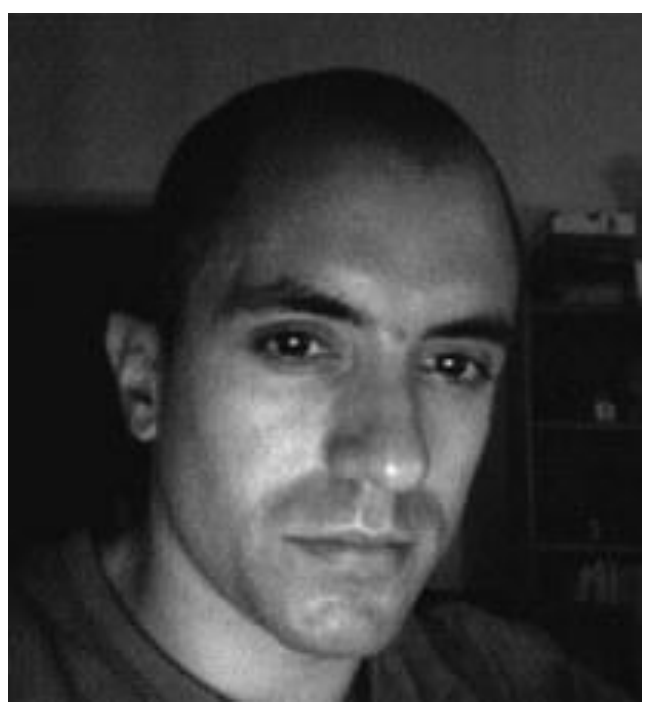

Figura 59

\section{Ivan Serra}

Vive e trabalha em Maputo, Moçambique

Ivan César dos Santos Serra, natural de Maputo, Moçambique, nascido em 1978. Concluiu o nível médio em Gráficas na Escola Nacional de Artes Visuais, ENAV, em Maputo.

No período de 1998-2001 finaliza o B Tech Degree (Licenciatura) em BelasArtes com especialização em escultura e teoria de arte, na Technikon Natal em Durban, República da África do Sul.

Em 2002, foi docente na Escola Verney, na cidade natal, lecionando a disciplina de Educação Visual, $8^{\circ}$ e $9^{\circ}$ anos.

Atualmente, exerce atividade profissional na área publicitária, com várias premiações. É membro desde 2004 do Movimento de Arte Contemporânea de Moçambique, MUVART.

Iremos apresentar os trabalhos de Ivan Serra inseridos na exposição ExpoArte Contemporânea, organizada pelo MUVART, edições de 2004 e 2006. O artista tem exposições em Portugal e na Itália.

A mostra Expo-Arte Contemporânea, 2004 que se realizou no Museu Nacional de Arte, MUSART, em Maputo. Ivan Serra participa com o trabalho $O$ Paradoxo da Publicidade, 2004, uma instalação (Fig. 60). Sobre seu trabalho, SERRA diz: 
Vivemos num mundo de contrastes, onde as altas sociedades de consumo dos países industrializados parecem viver quase ou completamente alienadas da realidade do resto do mundo. É um contraste evidenciado pelos meios de informação, onde ambas as realidades parecem viver em simbiose...Ficarão para sempre marcadas na minha memória as palavras de Oliviero Toscani (fotógrafo polêmico pelas suas campanhas para a Benetton sem imagem do produto......onde afirmou: Quando o resto das áreas de comunicação visual debatem abertamente os problemas reais do planeta, em que realidade vive a publicidade? É banal, estúpida e surreal...grande parte dela parece direccionada para um público alvo restrito e ávido de coisas materiais e idéias de beleza inatingíveis... Esta instalação tem como objectivo levar o espectador a questionar-se sobre um tema pouco debatido.

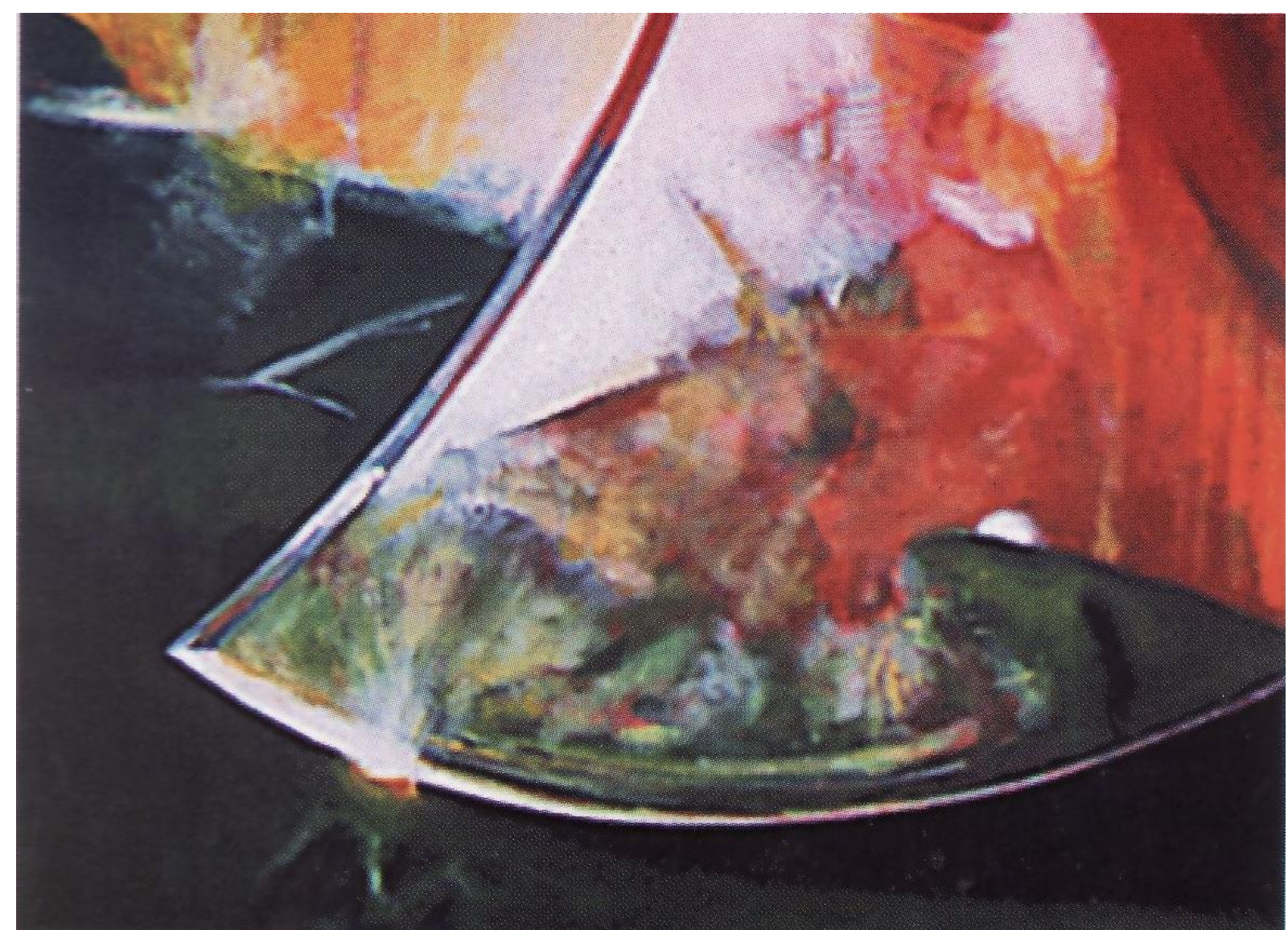

Figura 60

O Paradoxo da Publicidade (pormenor, inacabado)

Instalação em técnica mista

dimensões variávies, 2004

Ivan propõe uma análise da cultura de massa. Faz-nos recordar os pressupostos da Pop Art, para o artista inglês Richard Hamilton isso significava:

popular (feita para o grande público); efêmera (extinção em curto prazo); descartável (facilmente esquecível); barata; produzida em massa; jovem 
(dirigida para a juventude); espirituosa; sexy; "macetada"; glamourosa; big business. ${ }^{151}$

E trabalhar com estes pressupostos pontuados por Richard Hamilton tornouse um estilo, mais conhecido como Pop Art. Ivan Serra tem trabalhado, paralelamente à sua condição de artista, na publicidade. Transita entre o universo da linguagem pertinente a esta área e à sua formação em escultura.

O artista tem também trabalhos em outras linguagens, tais como: desenho, pintura, fotografia, vídeo e instalação. Assim como Carmem Muianga, que elege a gravura, o artista vai se fixando na escultura.

Com abordagens diferentes, suas duas participações na Bienal Expo-Arte Contemporânea trazem discussões em modalidades antagônicas que vão do contexto mais geral, no sentido da sociedade e no âmbito do foro íntimo.

A dimensão desta experiência é partilhada com o público, que reconhece inicialmente o "objeto" para num segundo momento reconstruir a sua significação. O trabalho de Serra é também o inverso da proposta de Xavier M'Beve que traz de volta ao objeto a materialidade da qual ele é constituído.

Trabalha com um material pouco convencional para 0 quotidiano moçambicano, mais identificado com as esculturas feitas em talha de madeira ou em pedra e cerâmica, Serra utiliza o metal e a luz e esconde a essência do objeto, a madeira. Na mostra Expo-Arte Contemporânea, 2006, que se realizou no Museu Nacional de Arte, MUSART, em Maputo, Ivan Serra participou com a instalação $A$ Perda da Inocência, 2000 (Figs. 61 e 62), que se notabiliza por estas características.

SERRA fala do seu trabalho:

O objectivo deste projecto é desconstruir e reconstruir objectos/ícones que possuam ou simbolizem alguma ligação emocional com o meu passado, conferindo-lhes uma nova identidade, melhor identificada com o lado obscuro do acontecimento retratado. $O$ objecto assume uma nova personalidade. Sofre uma metamorfose para um objecto de tortura gótico. $O$ seu esqueleto é reconstruído e o que resta da sua face de madeira original, esconde-se por dentro de uma armadura repleta de rebites, acessórios frios, cortantes e pontiagudos. Estou interessado em analisar o efeito destes objectos renascidos sobre as pessoas. ${ }^{152}$

A escultura vai alterando sua estrutura de percepção e dimensão até a contemporaneidade. Na proposta de Ivan, o objeto perde sua função e significado

\footnotetext{
${ }^{151}$ FARTHING, Stephen (Editor geral). Tudo sobre Arte, Os movimentos e as obras mais importantes de todos os tempos, Sextante: Rio de Janeiro, 2011, p.484.

${ }^{152}$ Expo-Arte Contemporânea, op. cit., 2006, p.65.
} 
inicial para constituir outra identidade, como sugere o artista. Mais uma vez observamos que estes objetos são retirados de um universo íntimo, autoral.

Em entrevista concedida em julho de 2010, Ivan Serra comenta que se trata de um projeto a longo prazo, no qual irá selecionando objetos (móveis) pessoais que estejam diretamente ligados a sua história de vida, onde pretende trabalhar a sua superfície transformando-a. No processo de concepção deste projeto, imagina que também construiria um lugar onde todos estes objetos (agora esculturas) poderiam ser vistos permanentemente.

$\mathrm{Na}$ contramão da ideia de efemeridade contida na publicidade, este projeto trabalha na ideia da permanência. Presença física e simbólica.

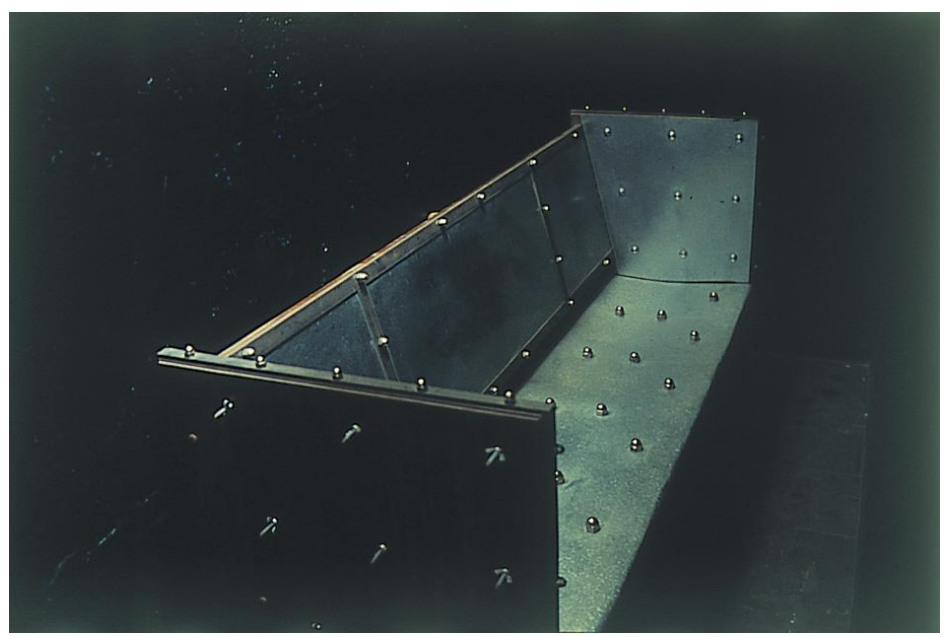

Figura 61

A Perda da Inocência (vista em perspectiva)

Escultura em madeira,metal e luz, dimensões variáveis, 2000

Figura 62

A Perda da Inocência

(vista frontal)

Escultura em madeira, metal e luz dimensões variáveis, 2000

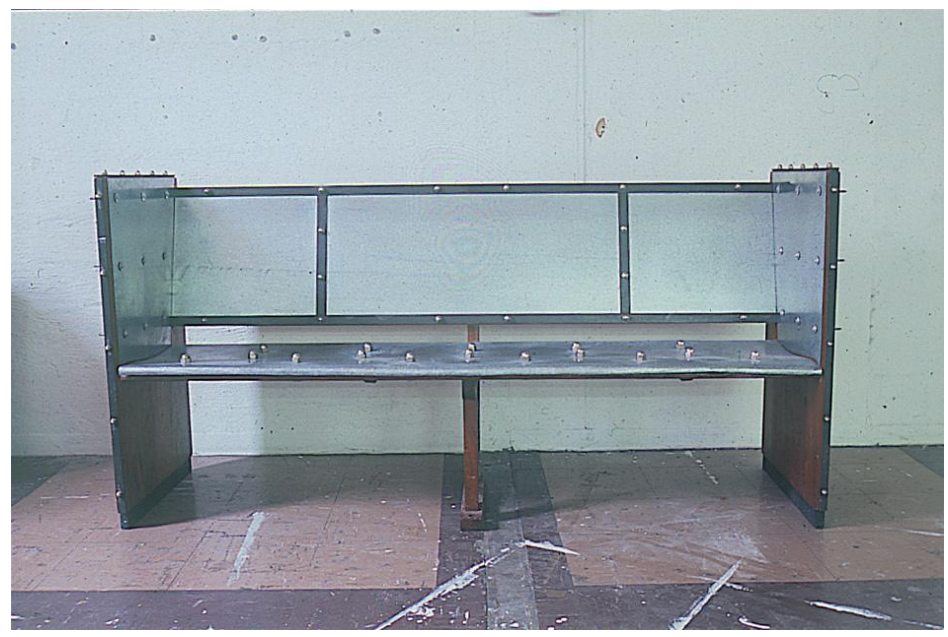




\subsection{JORGE DIAS}

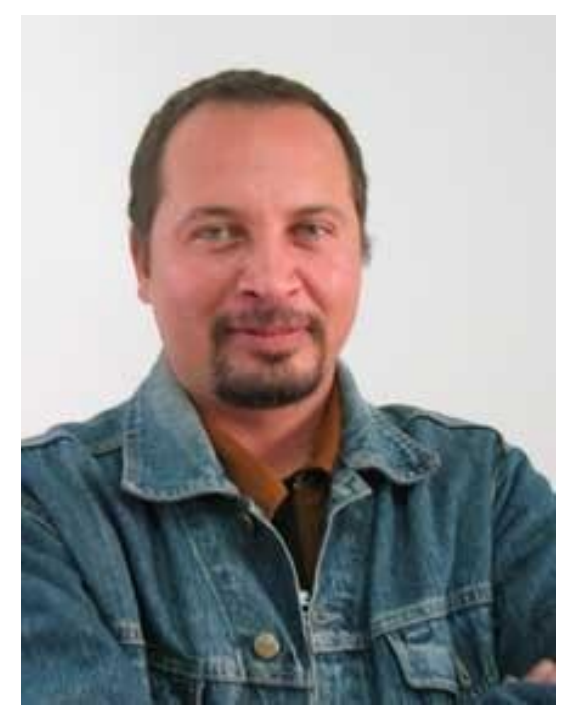

Figura 63

\section{Jorge Dias}

Vive e trabalha em Maputo, Moçambique

Jorge Manuel de Oliveira Dias, nascido em 1972, quando Maputo ainda era Lourenço Marques. Como a maioria dos artistas aqui retratados, é formado em Cerâmica na Escola Nacional de Artes Visuais, ENAV, em Maputo. Graduou-se no Brasil, na Escola de Belas-Artes, em Escultura, na Universidade Federal do Rio de Janeiro, Brasil.

Exerceu vários papéis na cena artística da cidade de Maputo: escreve nos principais jornais sobre arte, foi curador do Museu Nacional de Arte, MUSART: um dos fundadores do Movimento de Arte Contemporânea de Moçambique, MUVART. Atualmente além de artista atuante, é diretor da Escola Nacional de Artes Visuais, ENAV, em Maputo.

Iremos apresentar os trabalhos de Jorge Dias inseridos na exposição ExpoArte Contemporânea, organizada pelo MUVART, edições de 2004 e 2008, a seguir.

Ao apresentar a produção escultórica de Jorge Dias, observaremos que sua abordagem plástica deixa de lado alguns cânones da escultura e já constitui outros pensamentos acerca da produção do espaço, abordagem esta contemporânea. Discutindo a escolha dos materiais, os temas e sua espacialidade, GALL comenta: 
En regardant l'oeuvre de Jorge Dias sous l'angle d'une synthèse radicale de l'existence culturelle africaine dans la situation actuelle, je conclurais qu'elle opère la défragmentation d'un imaginaire et d'une mémoire sociaux et culturels qui se fondent et se refondent dans um tumultueux débat intellectuel sur l'existence dans des milieux urbains comme Maputo, Rio de Janeiro, Lisbonne et Porto. ${ }^{153}$

Justamente, a partir do entendimento da técnica da escultura, deflagra-se no processo artístico de Jorge Dias o manuseio constante de outros materiais, muitos encontrados no quotidiano mesmo, e também a necessidade de repensar este mesmo trabalho repetidas vezes, elaborando assim a sua linguagem e a sua inserção nos diferentes contextos. Ao formar-se no Brasil é incontestável a absorção da influência dos artistas brasileiros em seu percurso; personalidades como Lygia Clark, Hélio Oiticica, entre outros artistas são aproximações com os universos poéticos de Jorge Dias. A obra de Lygia Clark é fundamentalmente construída na compreensão espacial, com forte cunho psicológico e com a participação do público. Aqui vemos uma conexão direta com a obra de Jorge Dias, como no trabalho exposto na Expo-Arte Contemporânea, em 2004. As proposições de DIAS seguem esta direção e poderemos notar o mesmo trabalho repetidas vezes, nas mais distintas mostras, mas também, inacreditavelmente, um novo trabalho. É sobre esta matriz de pensamento artístico que mostramos a produção artística de Jorge Dias, na instalação Sem título, 2004, (Fig. 64).

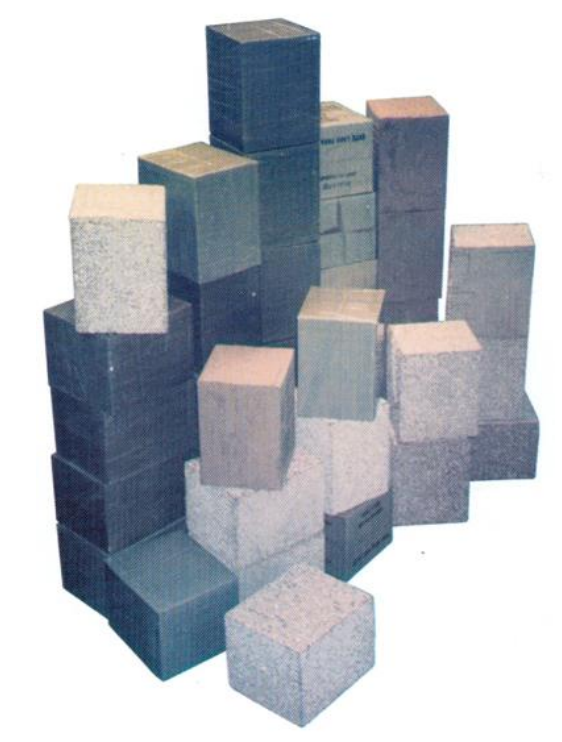

Figura 64 Jorge Dias

Sem título

Materiais diversos

Dimensões variadas

2004

${ }^{153}$ GALL, Le, Loic. Les Carnets de la création, Éditions de l'oeil, Mozambique, 2008. "No que respeita à obra de Jorge Dias sob o ângulo de uma síntese radical da existência cultural africana na atualidade, eu concluiria que ela reescreve um imaginário e uma memória social e cultural que se funda e refunda num tumultuoso debate intelectual sobre a existência nos meios urbanos como Maputo, Rio de Janeiro, Lisboa e Porto." Tradução livre da autora. 
Sobre o seu trabalho:

O ser humano executa uma série de tarefas físicas como: ficar em pé, sentar, saltar, dar um passo à frente, inclinar-se, transportar algum objecto..., fazendo tudo isso desde que nasce e muitas vezes não se dando conta. O homem também precisa de organizar o espaço onde vive, circula, trabalha e tudo isso requer dele uma ordem individual ou colectiva que varia de indivíduo e de grupo social, político e cultural.Juntando essas duas realidades, proponho um espaço de exercício físico e ordem permanente....Nesta instalação o observador/espectador é convidado a juntar, a recompor/reagrupar as peças ao seu critério (individual ou colectivo)... A instalação torna-se num exercício sem tempo e forma definidas, torna-se um organismo vivo através de um diálogo estrutural permanente. ${ }^{154}$

A instalação Caixas, 2004, constitui-se de caixas de cartão, com dimensões variáveis, revestidas com papel, tecido ou fita adesiva que recriam a fase intitulada Pós-Casulos, obra esta interativa, em que o público é convidado a manipulá-la, alterando sua posição no espaço (Fig. 64).

Ao ser indagado sobre este trabalho, DIAS explica:

A Obra "Caixas. Actividade Sistemática" é o titulo correto dela foi mostrada na expo arte contemporânea 2004 no lado de fora do Museu, já tinha revestimento sim.

Depois foi mostrada na expo do Humanos no Museu Nacional de Arte numa exposição em que participei com o Gemuce.

Foi mostrada também em Portugal numa exposição em que participei com Nelson Leirner chamada de "Zoologia dos trópicos", em 2005 e a ultima vez foi mostrada em Maputo numa exposição do MUVART em 2008. ${ }^{155}$

A dúvida era sobre o título e apresentação da obra, na Expo-Arte Contemporânea, em 2004; o trabalho era "Sem título". Eram as "caixas" que no catálogo aparecem sem revestimento, mas que na realidade, no momento de sua exposição, encontravam-se revestidas como declara o artista e como também pude observar pessoalmente. Outra foto com o título de Caixas, 2004, (ver fig.65) agora com acabamento e em um espaço privativo; a anterior fora mostrada nos jardins do MUSART.

Em 2008, a obra recebe seu último título, Caixas. Actividade Sistemática, ou seja, o artista permanece pensando a mesma obra durante o transcorrer do tempo.

Este trabalho é um bom exemplo de como funciona a matriz de pensamento de Jorge Dias, e de todo o seu percurso artístico.

\footnotetext{
${ }^{154}$ Expo-Arte Contemporânea, op. cit., 2004, p.34-35.

155 Depoimento do artista via e-mail, março.2011.
} 


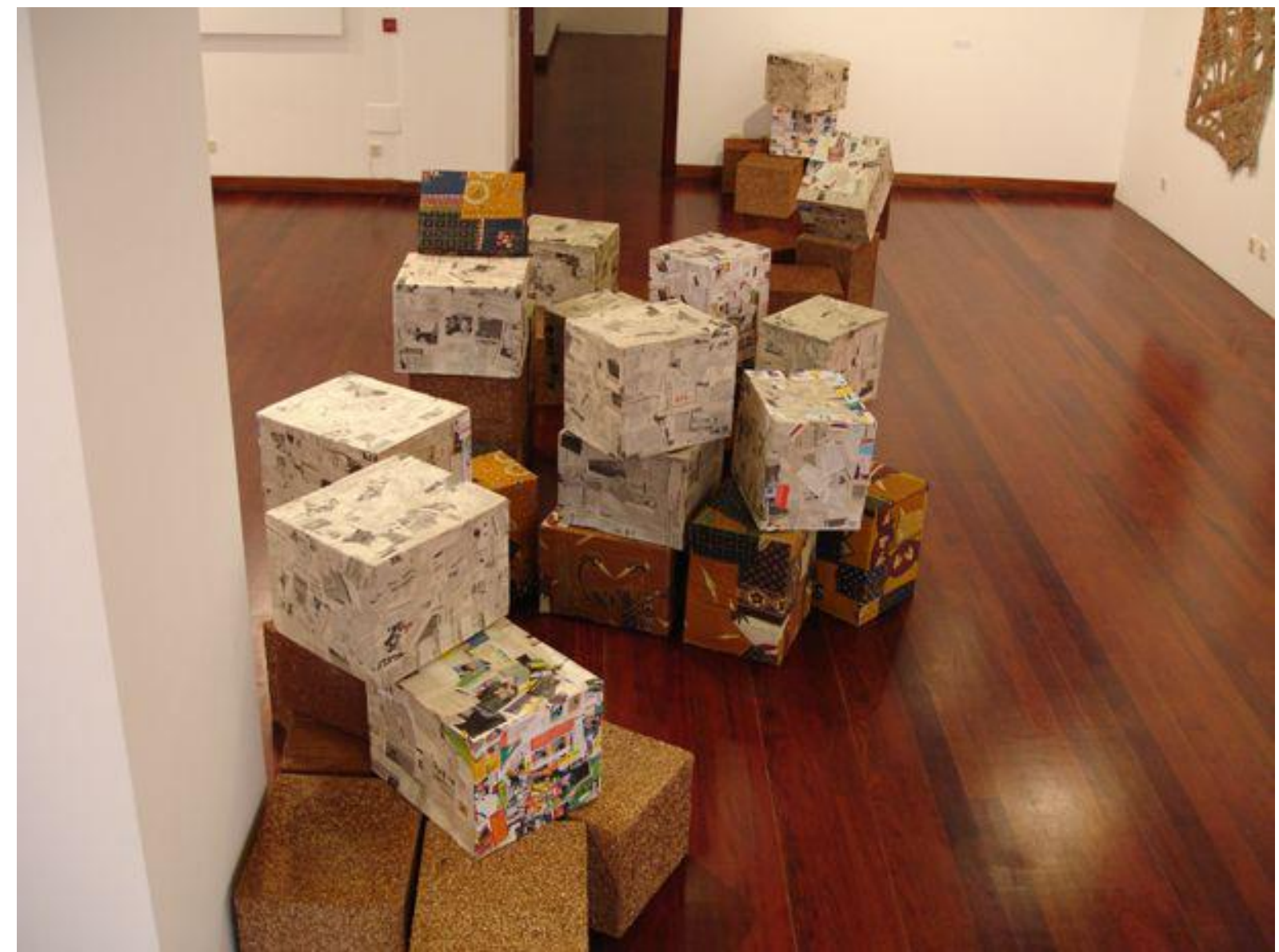

Figura 65 Jorge Dias

Caixas

Dimensões variáveis, 2004

Em 2008, confirmando a parceria, a Expo-Arte Contemporânea realizou-se no Museu Nacional de Arte, MUSART, em Maputo. Desta vez, com a instalação Crise Aritmética - Os que aprendem a somar não sabem dividir, 2008 (Figs. 66, 67, 68 e 69). Segundo o artista:

Acho importante por uma imagem que vem os pintos embalsamados virados para o vídeo. O trabalho "Crise Aritmética. Os Que Aprenderam a Somar Não Sabem Dividir" consiste em um vídeo de um homem a comer frango enquanto que 8 pintos embalsamados estão virados para o vídeo, como se estivessem a ver a ação. O vídeo tem a duração de 18 minutos. É muito importante a escala do vídeo, porque procurei fazer uma projecção para a escala dos pintos.

Pretendo com isso abordar a problemática do ciclo vicioso. Uns nascem para servir e outros para serem servidos. ${ }^{156}$

$\overline{156}$ Depoimento do artista via e-mail, junho.2011. 


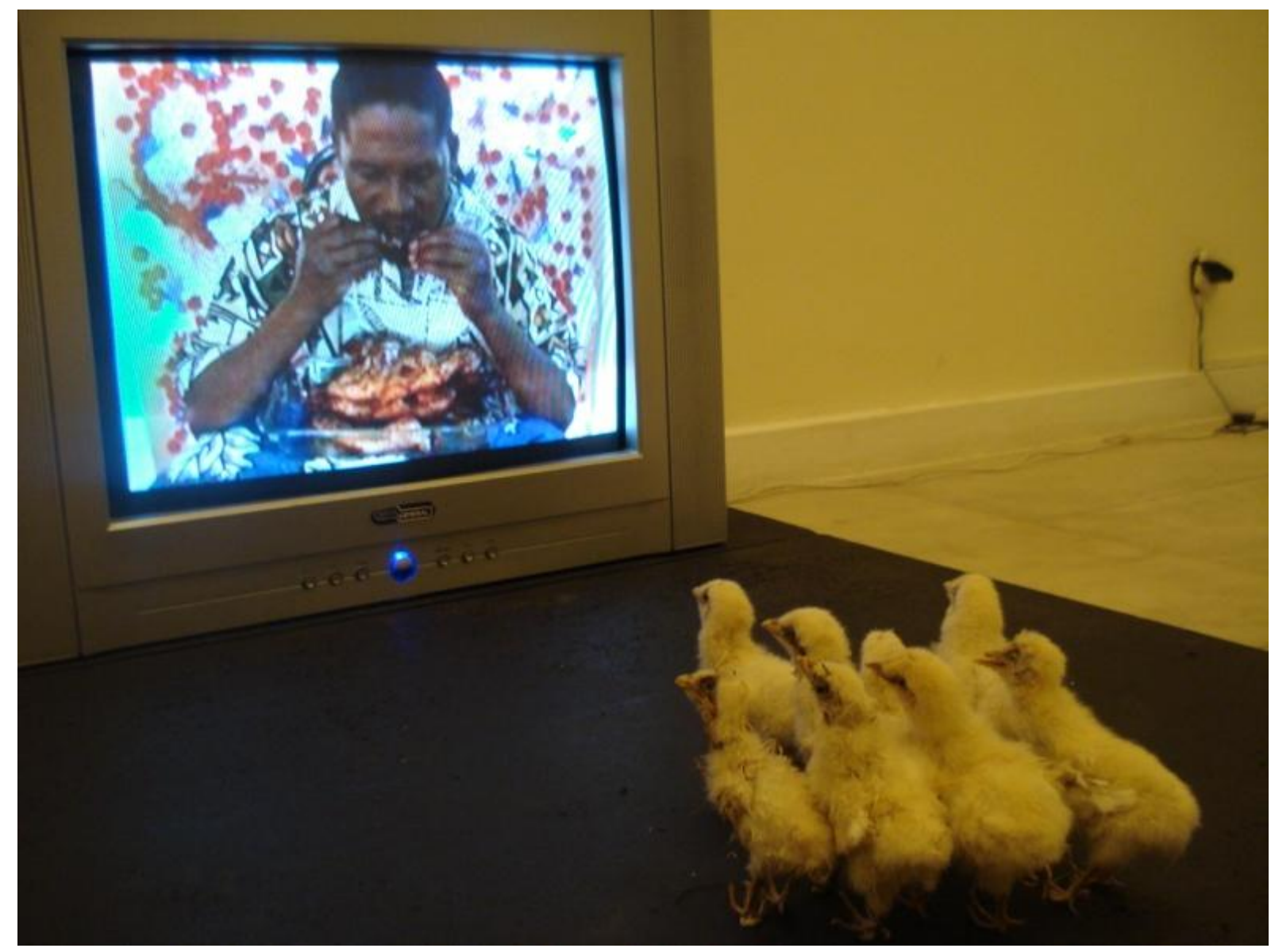

Figura 66 Jorge Dias

Crise aritmética - Os que aprendem a somar não sabem dividir (detalhe)

Pintinhos embalsamados, tv e vídeo

2008

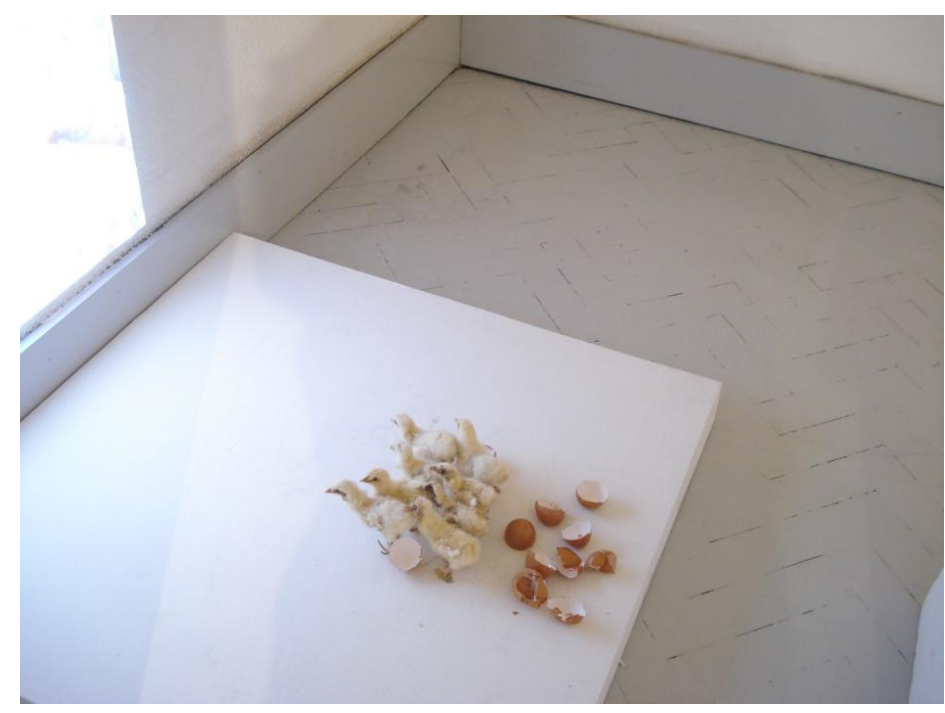

Figura 67 Jorge Dias

Crise aritmética - Os que aprendem a somar não sabem dividir (detalhe) 2008 


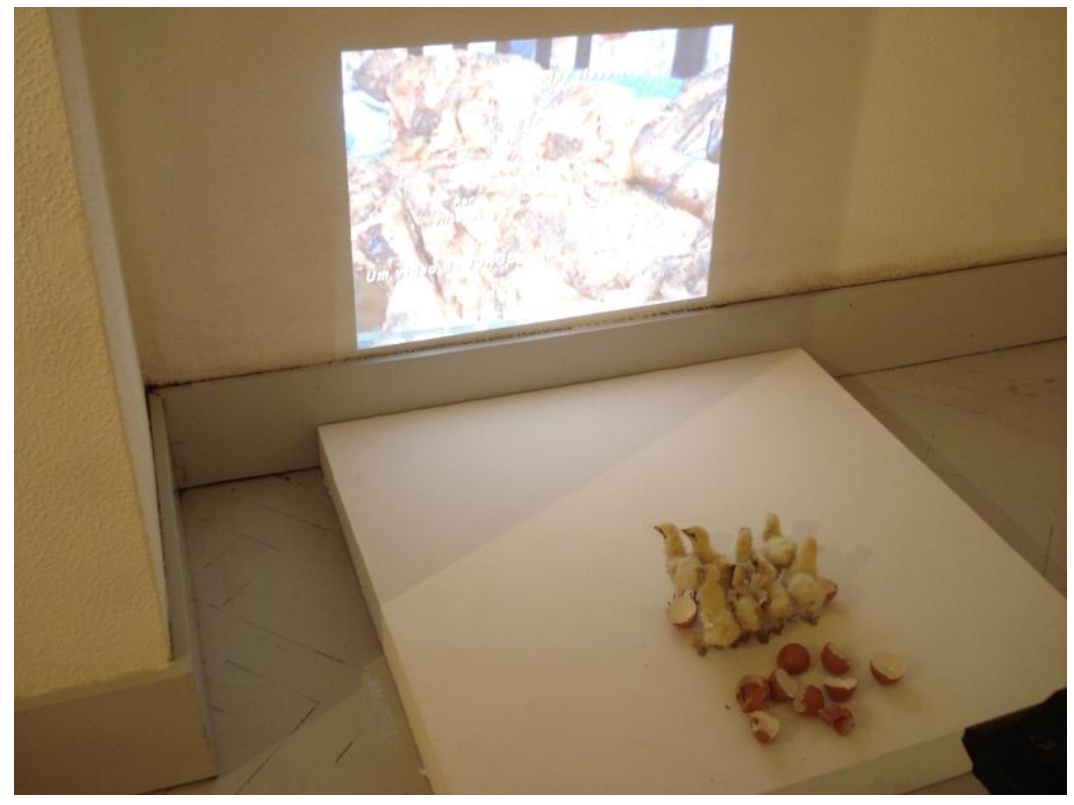

Figura 68 Jorge Dias

Crise aritmética - Os que aprendem a somar não sabem dividir (detalhe) 2008

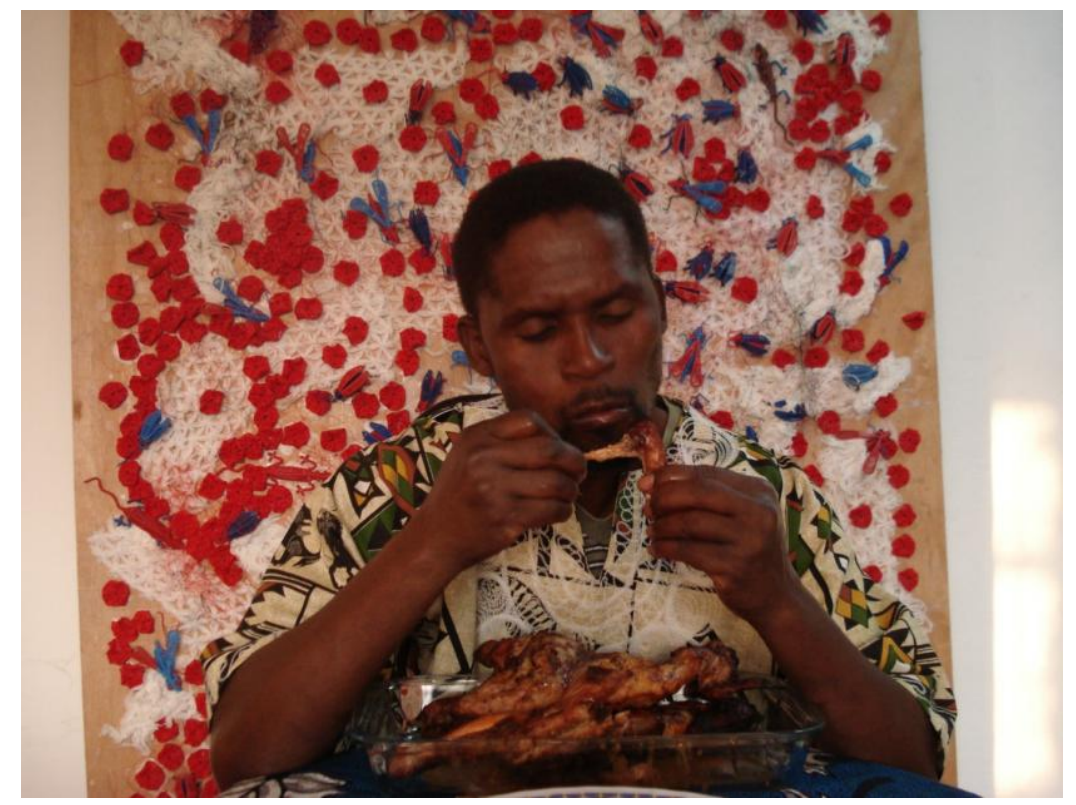

Figura 69 Jorge Dias

Crise aritmética - Os que aprendem a somar não sabem dividir (detalhe) 2008 
Jorge Dias tem sem dúvida uma produção extensa e contínua. No Brasil enquanto estudante bolsista, na Universidade Federal do Rio de Janeiro, também foi atuante, tanto quanto o é na cena artística de Maputo, chegando a expor e participar das atividades acadêmicas tais como os Salões de Arte, entre outros eventos. Com a experiência adquirida retornou à cidade natal com suas inquietações.

Neste sentido, a sua temática espelha-se muito na realidade do país, motivado a experimentar os mais diversos suportes; intelectualmente está mais próximo das questões da atualidade, não tendo sua obra um discurso estético diretamente ligado a uma tradição.

Em Caixas, 2004 e Crise aritmética - Os que aprendem a somar não sabem dividir, 2008, a preocupação com a ação individual e a coletiva se releva, a proposta exije do público uma participação ativa, fisica e intelectual, ou seja, a percepção espacial insere também a dimensão humana. 


\subsection{LOURENÇO EUGENIO COSSA}

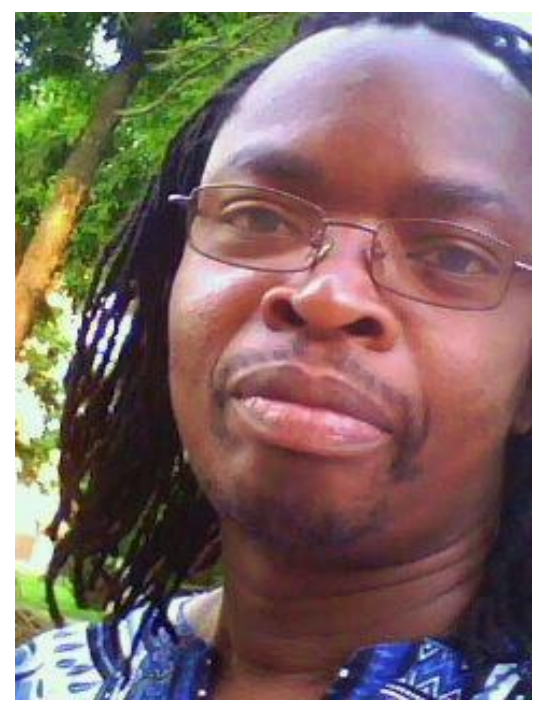

Figura 70

\section{Lourenço Eugenio Cossa}

Vive e trabalha em Porto Alegre, Brasil

Lourenço Eugenio Cossa, nascido em 1969, em Maputo, Moçambique. Em 2000 gradua-se no Brasil, com Bacharelado em Artes, em Escultura e também conclui Licenciatura em Desenho e Plástica pela Universidade Federal de Minas Gerais, UFMG, Brasil.

Atualmente doutorando em Educação e Artes na Universidade Federal do Rio Grande do Sul, com o projeto de tese Processos de Significação dos Conhecimentos em Arte no Ensino em Moçambique sob a orientação teórica da Semiótica Discursiva gremasiana.

Atua como professor na disciplina de Desenho, além de desenvolver pesquisa sob a orientação teórica Analista do Discurso de linha francesa. No Brasil é membro da Gearte ${ }^{157}$. Em 2004 é um dos fundadores do Movimento de Arte Contemporânea de Moçambique, MUVART. Ausenta-se neste período da cena artística moçambicana e não chega a participar das Bienais da Expo-Arte Contemporânea. Volta ao Brasil onde dá prosseguimento a sua formação na área de artes. Seu percurso acadêmico, porém, é pautado na contribuição científica sobre seu País.

157 Grupo de Pesquisa em Arte Educação, Gearte é um grupo interinstitucional que investiga as relações entre educação e arte, dialogando com as áreas da cultura visual, semiótica discursiva, estética, história, teoria e crítica da arte. Tem cinco linhas de atuação: pesquisa; ensino; publicação; assessoria; estudos específicos. Discute seus trabalhos com a comunidade acadêmica nacional e internacional. Há três grandes focos nas pesquisas: educação e artes visuais; educação: arte linguagem tecnologia; estudos em arte: mídia, discurso e formação. É formado por docentes e estudantes vinculados à linha de pesquisa Educação: Arte Linguagem Tecnologia, do Programa de Pós-Graduação em Educação da Universidade Federal do Rio Grande do Sul e pesquisadores de diferentes instituições. 


\subsection{MARCOS BONIFÁCIO "MUTHEWUYE"}

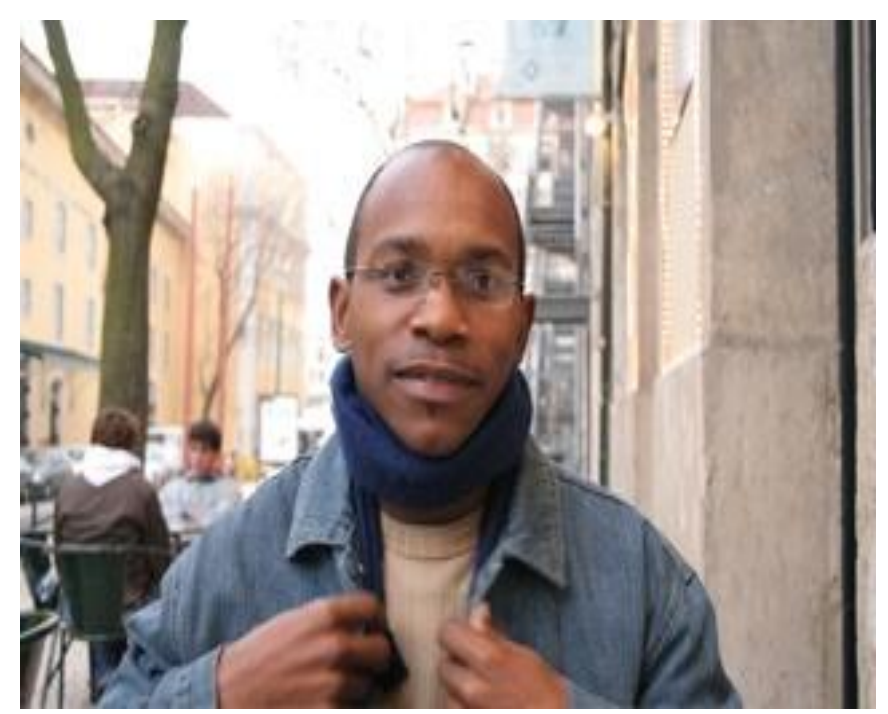

Figura 71

\section{Marcos Bonifácio "Muthewuye"}

Vive e trabalha em Maputo, Moçambique

Marcos Bonifácio "Muthewuye", nascido em 1972, em Manjacaze, Gaza. Concluiu o curso de cerâmica na Escola Nacional de Artes Visuais, ENAV, em Maputo. Em 1995 frequentou o curso de escultura na Escola Nacional de Artes Plásticas em Havana, Cuba. Posteriormente, graduou-se em licenciatura em Artes Plásticas no Instituto Superior de Artes de Havana, Cuba.

Exerce a sua atividade profissional como artista plástico e como professor na Escola Superior Técnica da Universidade Pedagógica e do Instituto Superior de Artes e Cultura, ISArC.

Expositor da Bienal Expo-Arte Contemporânea, nas edições de 2004, 2008 e 2010, todas coletivas. Em 2004, o artista apresenta-se na Expo-Arte Contemporânea, organizada pelo MUVART no Museu Nacional de Arte, MUSART, em Moçambique, desta vez com o trabalho Culimando Ideias, 2004 (Figs. 72 e 73).

Sobre seu trabalho, Muthewuye comenta:

No meu trabalho, o público é convidado a ser activo e não passivo perante a obra, eliminando a distância que normalmente existe entre eles, a favor da partilha de ideias que podem estar ou não ligadas ao mundo da arte, mas que passarão a fazer parte do gênero criativo dos homens e mulheres de hoje.

Em Culimando Ideias o espaço aparentemente privado é onde o público se inter-relaciona entre si e o espaço seguindo experiências colectivas ou individuais. 
Culimando Ideias mais do que um acto em si de cultivar, é um convite, uma incitação à construção ou criação de ideias a partir de experiências pessoais do público que absorve o mundo natural e artificial através dos órgãos sensoriais. ${ }^{158}$

Acrescentamos fotos cedidas pelo artista do processo do trabalho. A ideia de Culimar, que significa plantar, é irrepreensível para dar a dimensão da arte.

O resultado final deste processo resultou na construção de uma "casa" onde o público podia entrar; uma vez lá dentro deparava-se com letras presas nas paredes. A importância da arquitetura no processo cultural moçambicano e sua história oral é comentada por BANDEIRA e compartilhada por diferentes grupos étnicos:

A arquitetura é um dos vetores deste processo, por exemplo, entre os Macuas e os Nyungwe esta concepção também é fortemente influenciada por esta oralidade, o domínio da técnica de construção é considerado como um rito de passagem; entre o mundo dos jovens, infantil, para o mundo dos homens, adulto, que assim se capacitam ao deter o saber da construção, a sua própria casa, ou seja, interagindo na comunidade e na sua história como indivíduo. ${ }^{159}$

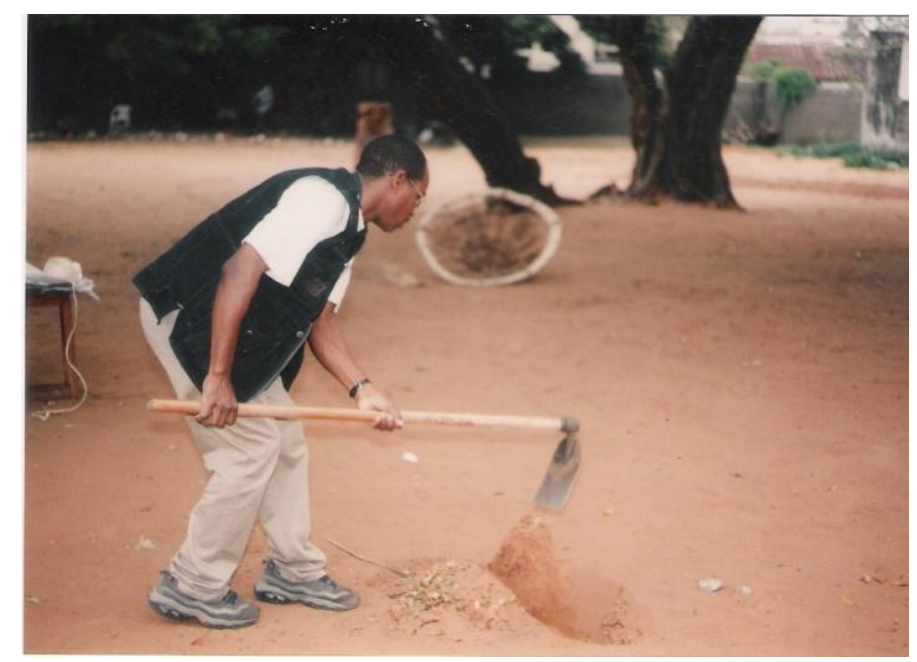

Figura 72 Marcos Muthewuye Culimando Ideias

Registro fotográfico do processo de construção do trabalho 2004

158 Expo-Arte Contemporânea, op. cit., 2004, p.37.

159 BANDEIRA, Isa. Arte tradicional Moçambicana: Os Macondes, Os Macuas, Os Tsongas e Os Nyngwes. Congresso Internacional NEHO 20 anos: História oral, Identidade e Diversidade, Universidade de São Paulo, São Paulo, 2011, p.4. 


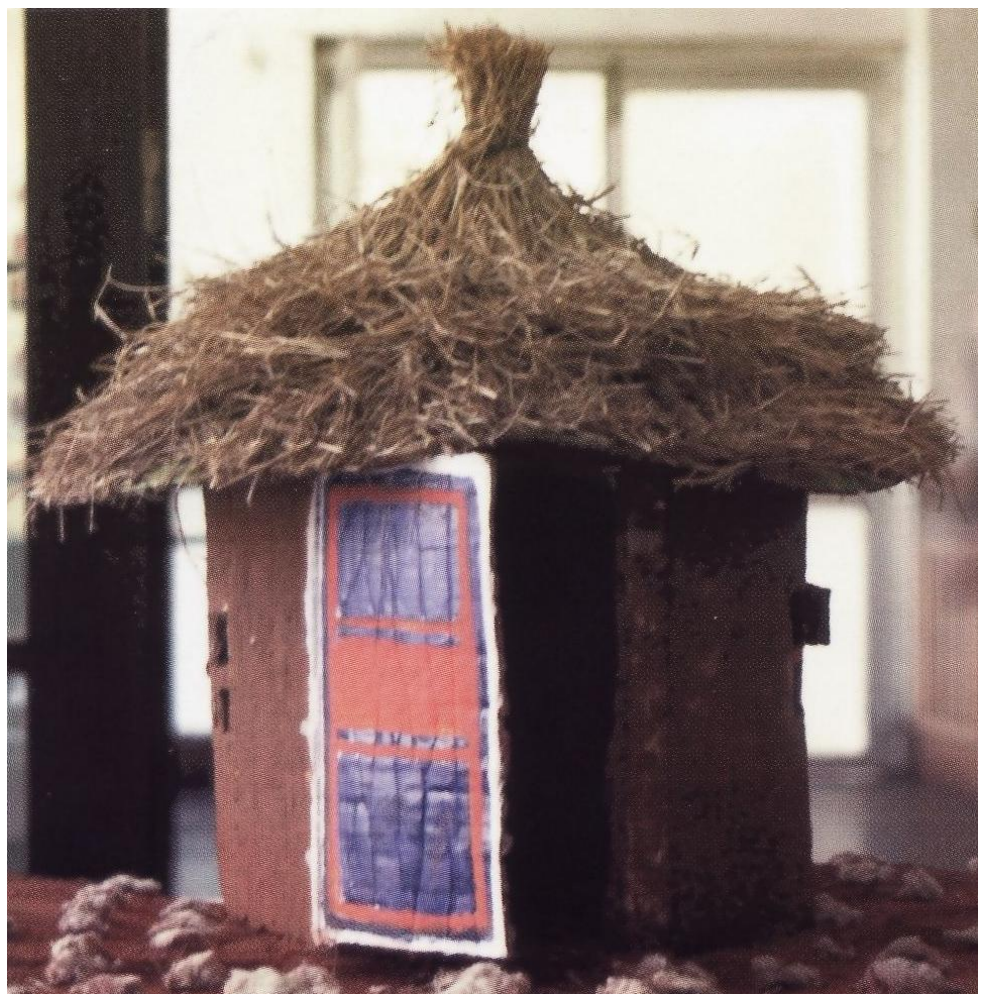

Figura 73 Marcos Muthewuye

Culimando Ideias (maquete) Instalação em técnica mista dimensões variáveis 2004

Em 2008, Marcos apresenta-se na Coletiva Expo-Arte Contemporânea, organizada pelo MUVART no Museu Nacional de Arte, MUSART, em Moçambique, desta vez com o trabalho Pensar a água ${ }^{160}, 2008$ (Fig. 74).

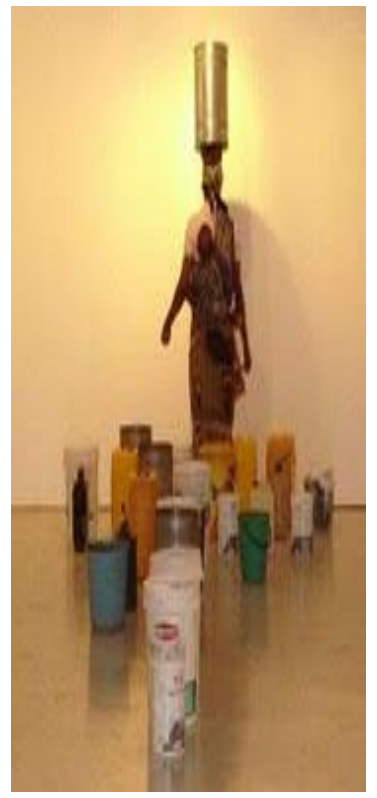

Figura 74 Marcos Muthewuye Pensar a água Instalação

Fotografia, baldes de plástico e de alunínio.

Dimensões variáveis

2008

${ }^{160}$ Expo-Arte Contemporânea, op. cit., 2008, p.02. 
Sobre este trabalho, acrescentamos a importância de discutir a água como fonte de vida; assim como Jorge Dias em Crise aritmética - Os que aprendem a somar não sabem dividir, 2008, a primeira leitura que se faz é de conteúdo local, porém esta discussão é de referência global. Utilizando elementos do dia a dia, os diversos tipos de baldes vão formando fila em direção à figura simbólica da mulher que carrega seu filho: na cultura tradicional moçambicana é ela a responsável pela comida, pela lavagem de roupa e todos os afazeres da vida doméstica, na qual a água é de fundamental importância, além de representar a saúde, a própria vida.

Em 2010, Marcos apresenta-se na Expo-Arte Contemporânea, organizada pelo MUVART, no Museu Nacional de Arte, MUSART, em Moçambique, desta vez com o trabalho Não é um Cemitério ${ }^{161}, 2010$ (Figs. 75 e 76)
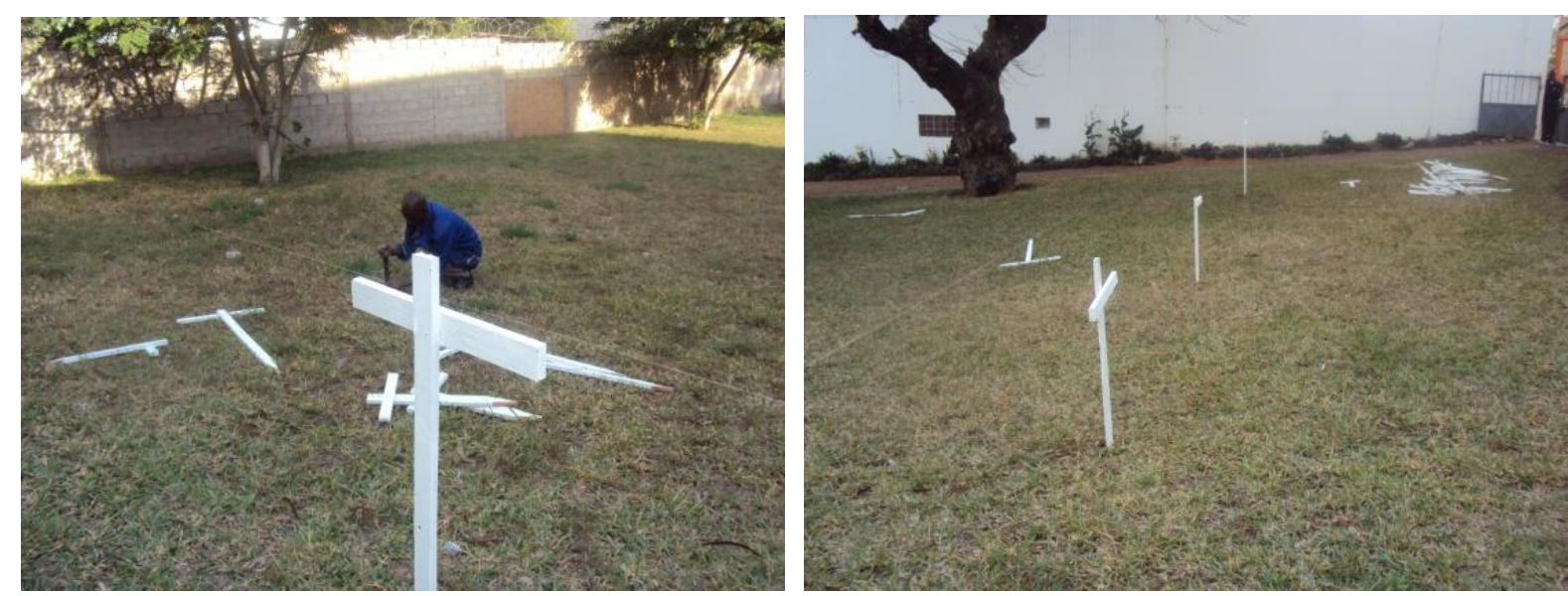

Figuras 75 e 76

Marcos Muthewuye

Não é um cemitério

Registro fotográfico do processo de construção do trabalho Multimídia

2010

Esta exposição e especificamente este trabalho foram alvo de reportagem ${ }^{162}$ no jornal local. Celso Ricardo, com texto na íntegra nos anexos, sobre a última Bienal do MUVART comenta:

161 Expo-Arte Contemporânea, catálogo da mostra, 2010, s/p.

162 Em Maputo existe uma crítica de arte que é exercida por artistas, como Jorge Dias que também é fundador do Movimento de Arte Contemporânea de Moçambique - MUVART. Observamos também a tendência contemporânea de acumular múltiplos papéis tais como o de curador e de crítico de arte. Porém outros também escrevem sobre o tema, como no caso da reportagem de Celso Ricardo do jornal O País. 
Das obras expostas uma chamou-nos atenção, e como seres mortais refletimos em torno dela, senão o cemitério não seria o local do fim absoluto? "depois da própria morte".

Mesmo assim, quem já imaginou um cemitério dentro de um museu? A obra em alusão é de autoria de Marcos Muhewuye. E, sobre ela há que abrir um parênteses e dizer que "nos tempos que correm é normal discutir-se os limites da arte para saber onde começa e onde termina o que são ou não objectos da arte? ${ }^{163}$

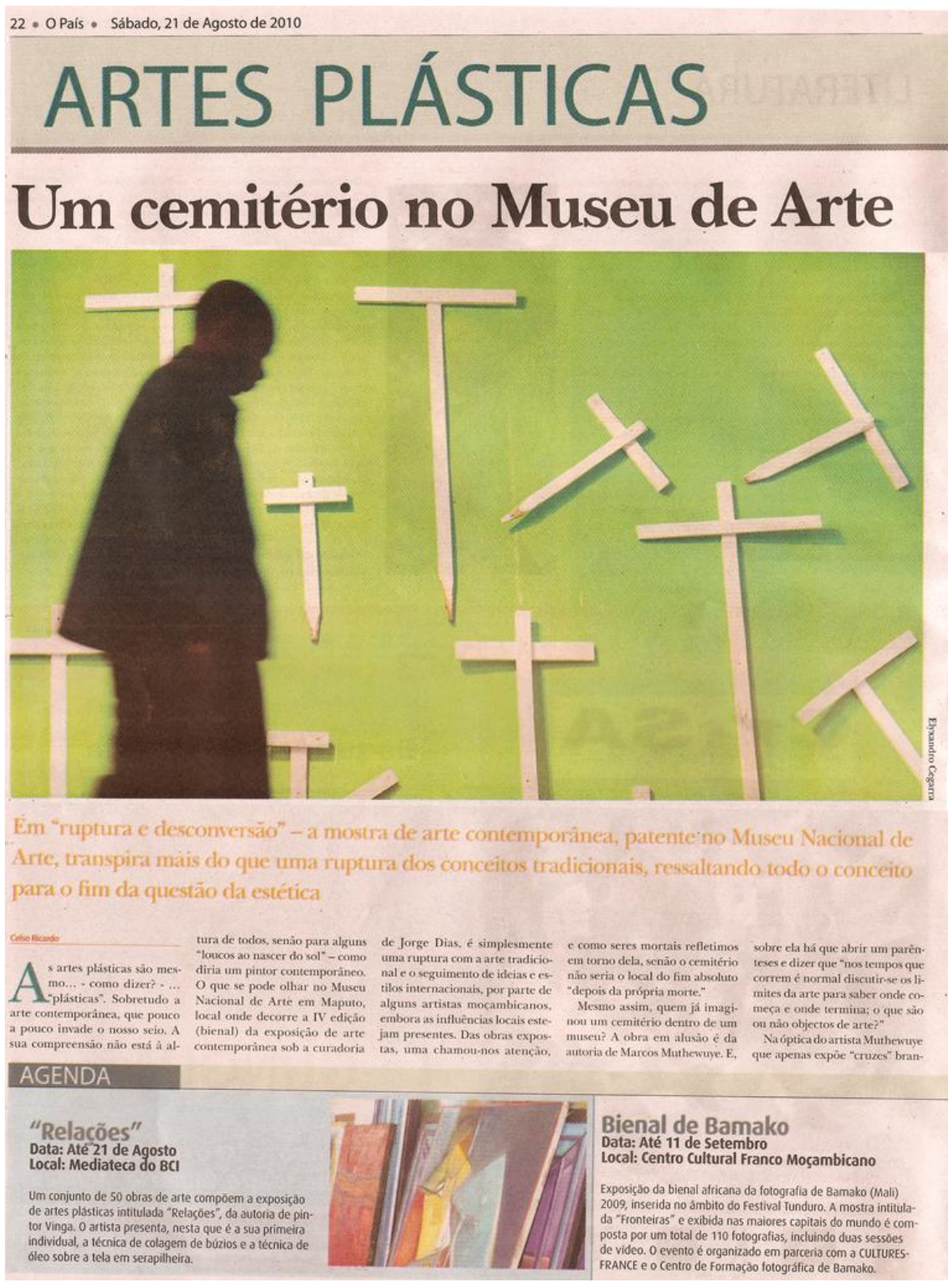

Figura 77

Reportagem RICARDO, Celso. Um cemitério no Museu de Arte

${ }^{163}$ RICARDO, Celso. “Um cemitério no Museu de Arte”, O País, 21.ago. 2010, p.22. 
Observa-se que a proposta do artista trouxe para a crítica e para o público um questionamento em relação à própria definição de arte e a sua materialidade. $O$ artista provoca um estranhamento no deslocamento do significado da obra de arte e mesmo em relação ao espaço de sua apreciação. A obra está fora (Figs. 75 e 76) e dentro do espaço expositivo (Fig. 78).

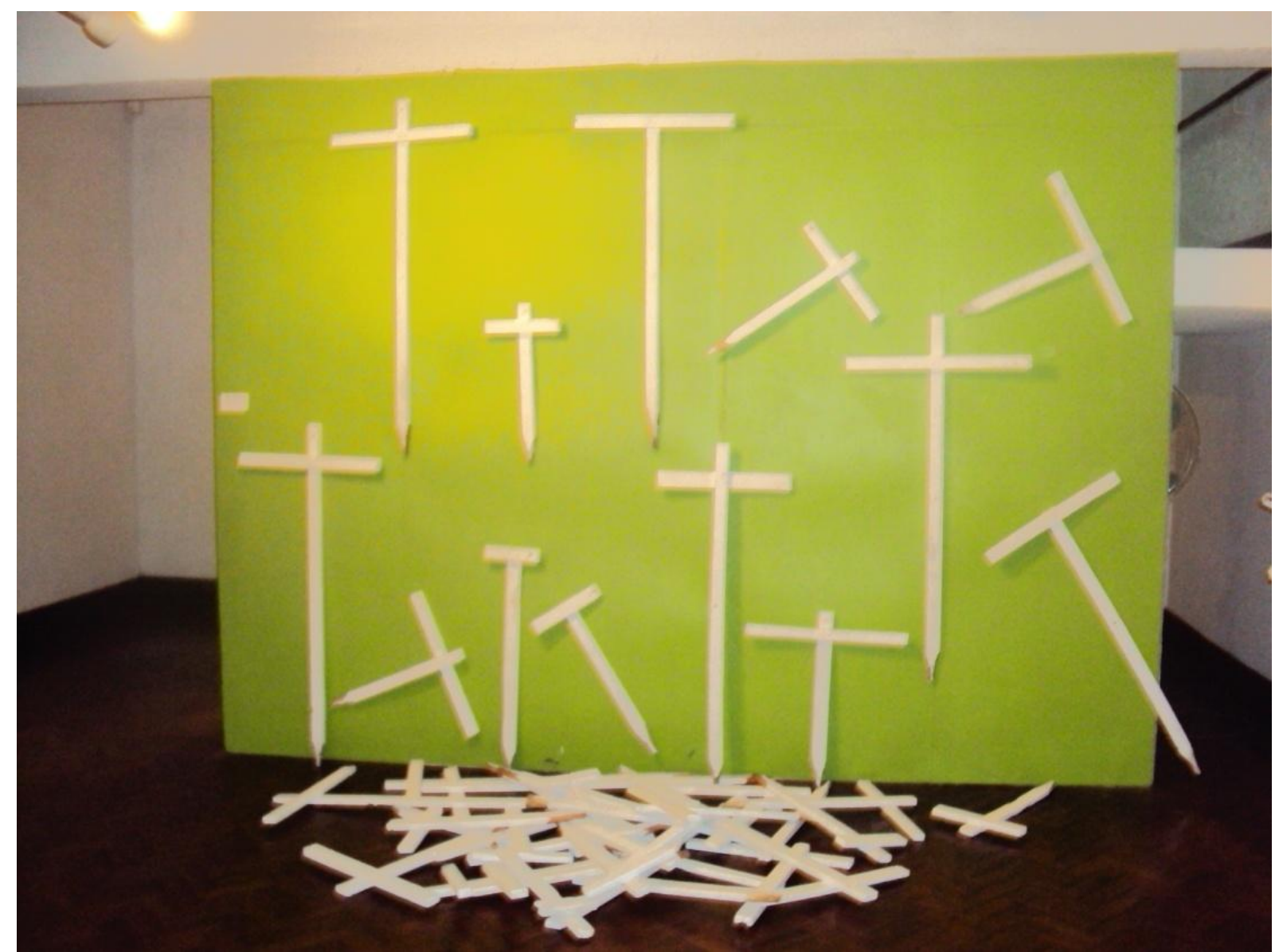

Figura 78

Marcos Muthewuye

Não é um cemitério

Madeira pintada

Dimensões variáveis

Pintura

$2 \times 3 \mathrm{~m}$

2010

A ousadia e a provocação têm sido características do trabalho do Muthewuye; em entrevista concedida em julho de 2010, comenta: "fui o primeiro artista a fazer uma performance em Maputo". O artista faz a crítica e o público pensar. 


\subsection{MONDLANE}

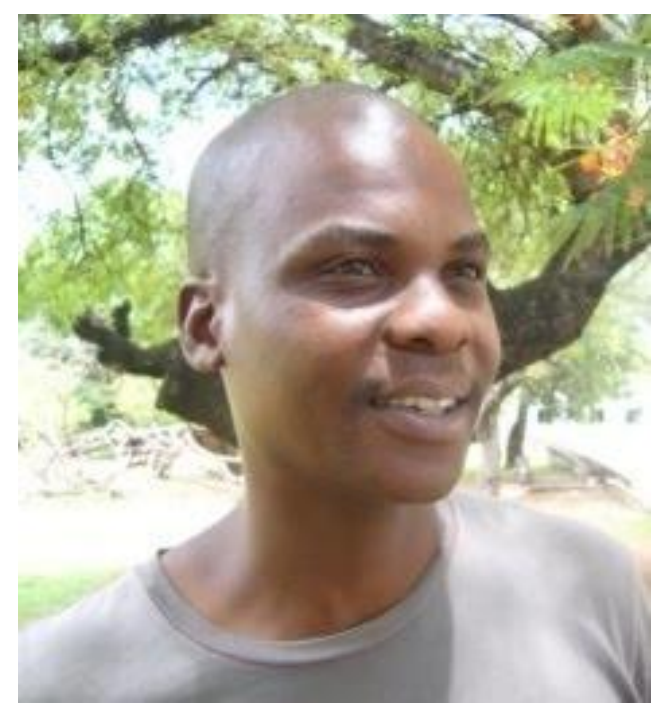

Figura 79

\section{Mondlane $^{164}$}

Vive e trabalha em Maputo, Moçambique

Celestino Bento, "Mudaulane", nascido em 1972 em Maputo, concluiu o Curso de Cerâmica na Escola Nacional de Artes Visuais de Maputo, a ENAV. É professor de cerâmica e desenho nesta instituição. Posteriormente, inscreve-se na Universidade Eduardo Mondlane no curso de História. Mondlane participa das Bienais Expo-Arte Contemporânea, organizadas pelo Movimento de Arte Contemporânea de Moçambique, MUVART, nas edições de 2004 e 2008.

Em 2004, Mudaulane, nome artístico adotado, apresenta-se na Expo-Arte Contemporânea, organizada pelo MUVART, no Museu Nacional de Arte, MUSART, em Moçambique, desta vez com o trabalho Embondeiro Mágico, 2004 (Fig 80). Sobre seu trabalho, o artista comenta:

\footnotetext{
O embondeiro - árvore robusta que consegue viver centenas de anos - tem uma cavidade enorme que serve de reservatório de água nas épocas secas. Para as populações nativas, esta árvore é sinônimo de força, durabilidade e firmeza.

Igualmente, faz parte da crença popular acreditar que o embondeiro carrega consigo poderes mágicos. Esta magia representada sob forma de figuras mitológicas imaginárias num contexto tipicamente africano. ${ }^{165}$
}

\footnotetext{
${ }^{164}$ É possível encontrar duas formas de grafia ao se tratar do nome do artista, ou seja Mondlane e Mudaulane; trata-se da mesma pessoa.

${ }^{165}$ Expo-Arte Contemporânea, op. cit., 2004, p.37.
} 
Os aspectos tradicionais fazem parte da temática deste artista, uma vez que isso é assumido no seu discurso formal e estético. Com uma prática voltada para a escultura e especificamente a cerâmica, trabalha com peças em grande dimensão; posteriormente adota a linguagem do desenho, também em grandes formatos.

Na concepção clássica da escultura, a peça exposta ainda contém elementos identificados nesta plástica, como a tridimensionalidade. A junção dos verbetes da cultura tradicional faz com que o público e a crítica local se identifiquem com a obra do artista.

A escultura de Mudaulane assume esse papel descritivo; a composição e o volume são fundamentais na narrativa do artista. Outros elementos também aparecem de forma secundária como a textura - no caso das peças em cerâmica são quase sempre ranhuras sobre a superfície. Esta linguagem que começa no desenho bidimensional vai ganhando espaço em peças cada vez maiores.

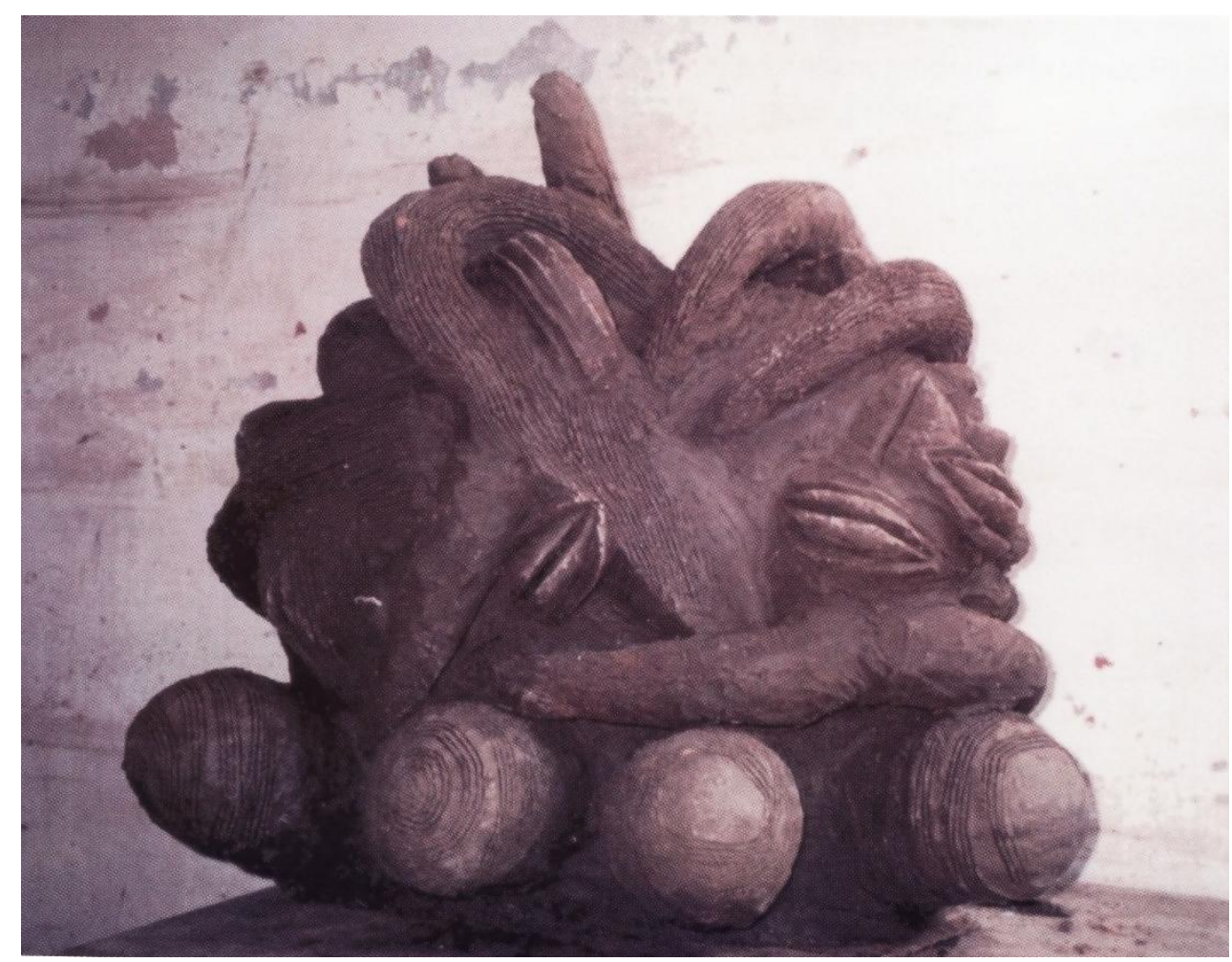

Figura 80 Mondlane

Embondeiro Mágico (detalhe)

Cerâmica

$200 \times 50 \times 30 \mathrm{~cm}$

2004 
Em 2006, Mudaulane apresenta-se na Expo-Arte Contemporânea, organizada pelo MUVART, também no Museu Nacional de Arte, MUSART, em Moçambique, desta vez com o trabalho Ndzumba, 2005 (Fig. 81).

Sobre seu trabalho:

Mudaulane pretende desvelar os mistérios latentes, que o ligam ao acontecimento espiritual, familiar e casual. Aprofunda-se um intercambio ambíguo entre si e uma série de referências do mundo real com o universo mitológico. Tem trabalhado no sentido de criar um "novo" código na produção contemporânea que esteja estritamente ligado às artes primitivas. Optou por composições bizarras, inquietantes e irônicas. Trilhou um caminho muito pessoal, afastado das propostas escultóricas apresentadas por Reinata, Anésia Manjate; Gemuce e Titos Mabota, onde a imagem do homem vai sendo desfeita no espaço real, social e espiritual, sendo transposta para um espaço mitológico e fantástico. ${ }^{166}$

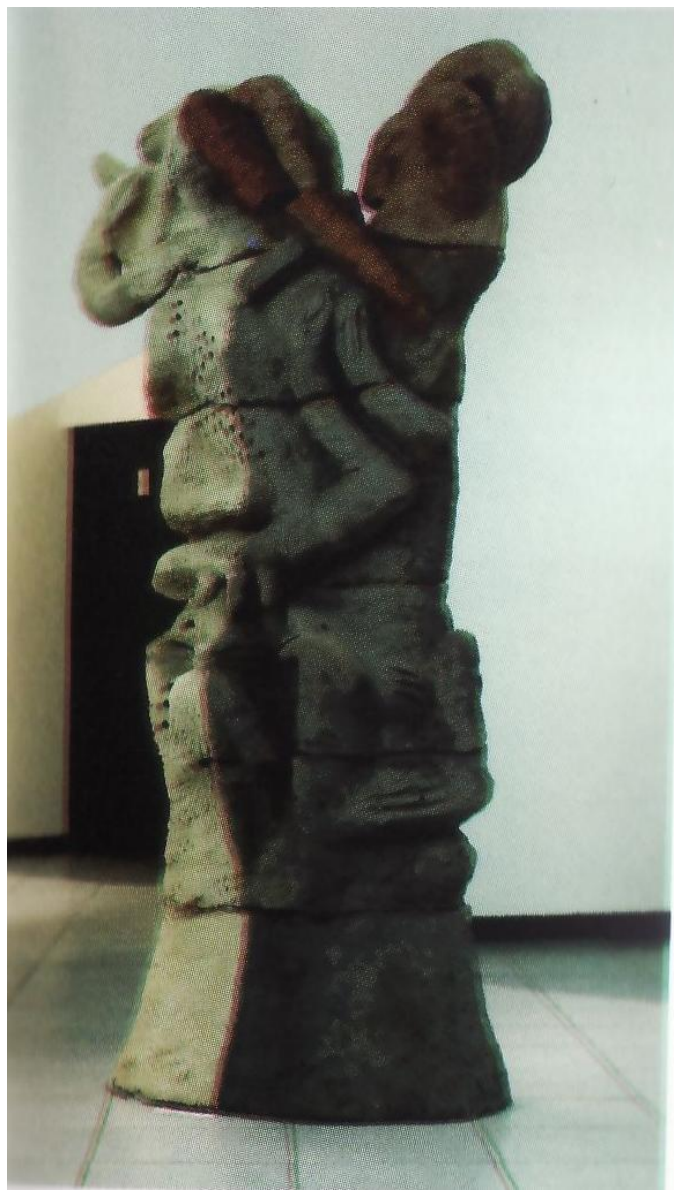

Figura 81 Mondlane

Ndzumba

Cerâmica

Dimensões variáveis

2005

Observa-se nesta peça a utilização do pedestal, porém este se integra ao aspecto geral da obra. Esta é uma das características da transição da escultura moderna para a contemporaneidade.

\footnotetext{
${ }^{166}$ Expo-Arte Contemporânea, op. cit., 2005, p.39.
} 


\subsection{QUENTIN LAMBERT}

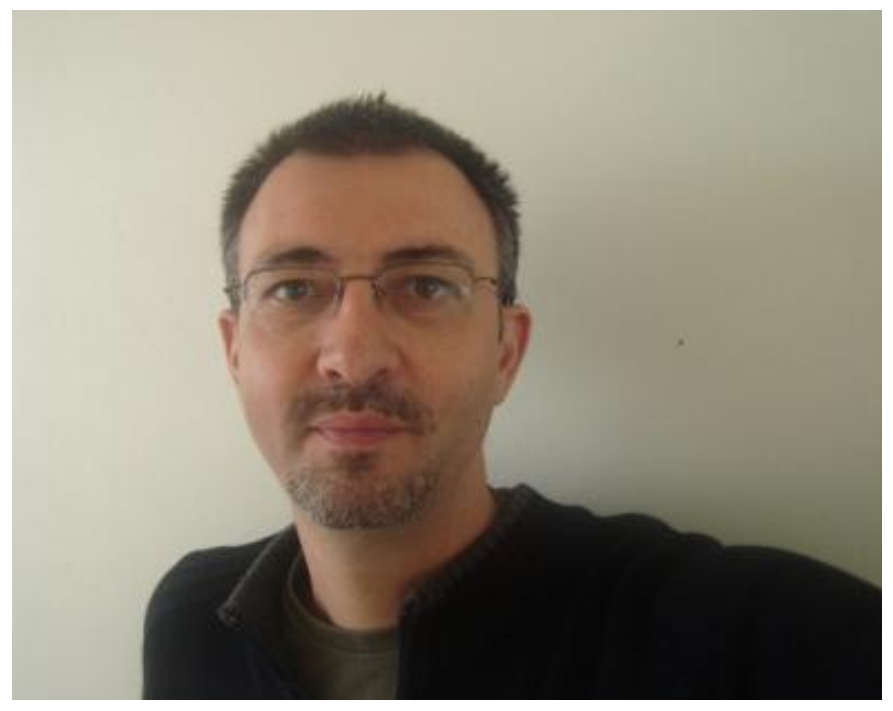

Figura 82

\section{Quentin Lambert}

Vive e trabalha em Sydney, Austrália

Quentin Lambert vive e trabalha em Sydney, Austrália. Atualmente Adido Consular da França, é membro fundador do Movimento de Arte Contemporânea de Moçambique, MUVART.

Lambert salienta que a experiência de integrar o grupo foi principalmente um momento de encontro e debate sobre a arte e um espaço de partilha. Membro fundador, participa posteriormente de coletiva organizada pelo grupo, tendo como base do seu trabalho a linguagem da literatura.

Inserido na exposição Expo-Arte Contemporânea, organizada pelo MUVART, edição de 2004, apresenta a obra Sem Título, 2004, (fig. 83), transitando entre a linguagem gráfica e a literatura e tem no registro da memória o mote de sua poética.

Neste trabalho o visitante era convidado a manusear o livro onde histórias poderiam ser lidas e em suas páginas Lambert inseria desenhos aquarelados, experimentos com a tinta, como afirma em depoimento o artista.

A base do trabalho ${ }^{167}$ nos faz lembrar os ready-made, pois o material usado, além do papel, a madeira, poderia fazer parte de um móvel qualquer. Trabalha-se com duas possibilidades de memória; a dos objetos e a pessoal.

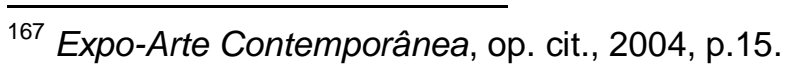




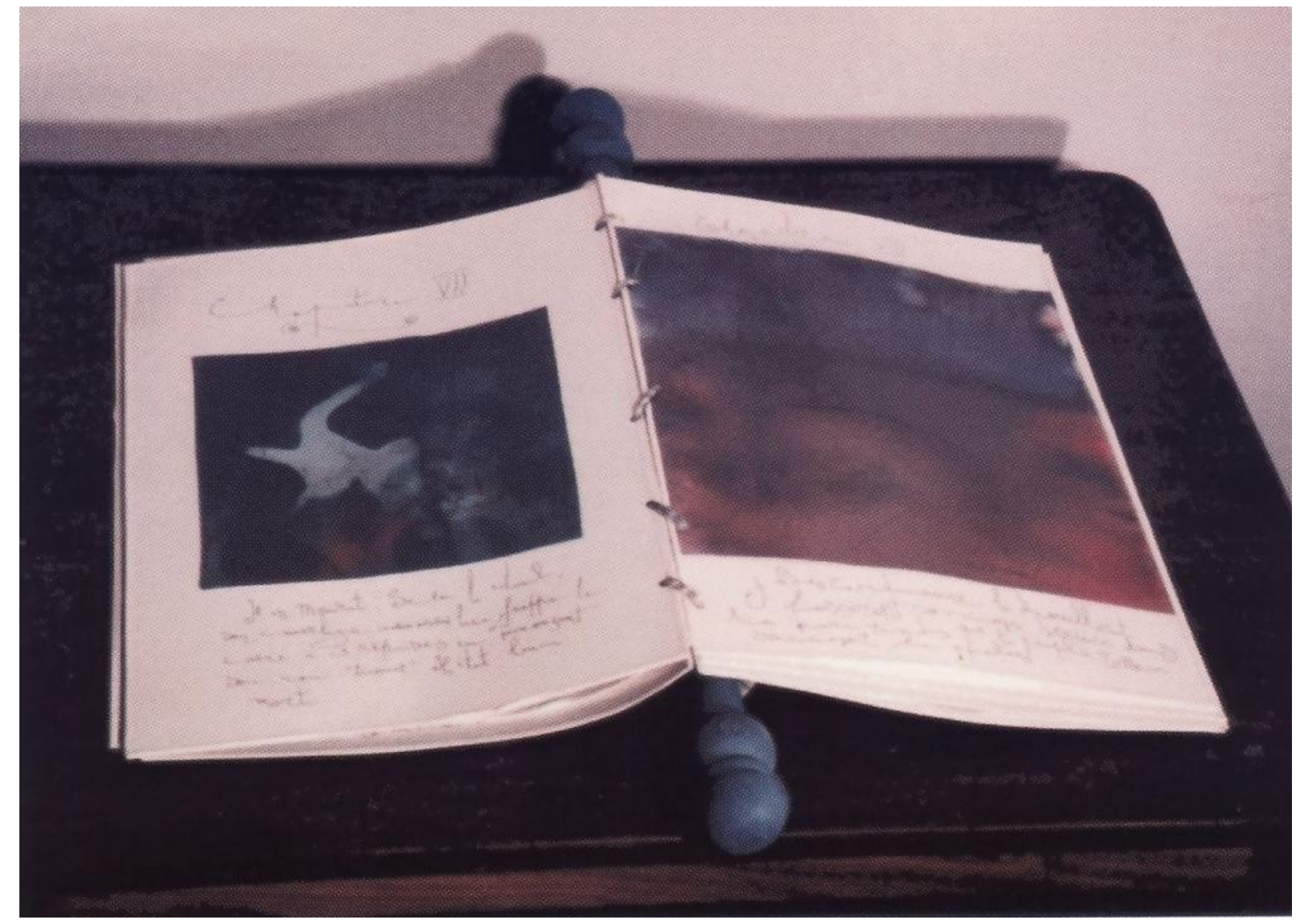

Figura 83 Quentin Lambert

Sem título

Livro - objeto, aquarela e texto

Dimensões variáveis, 2004

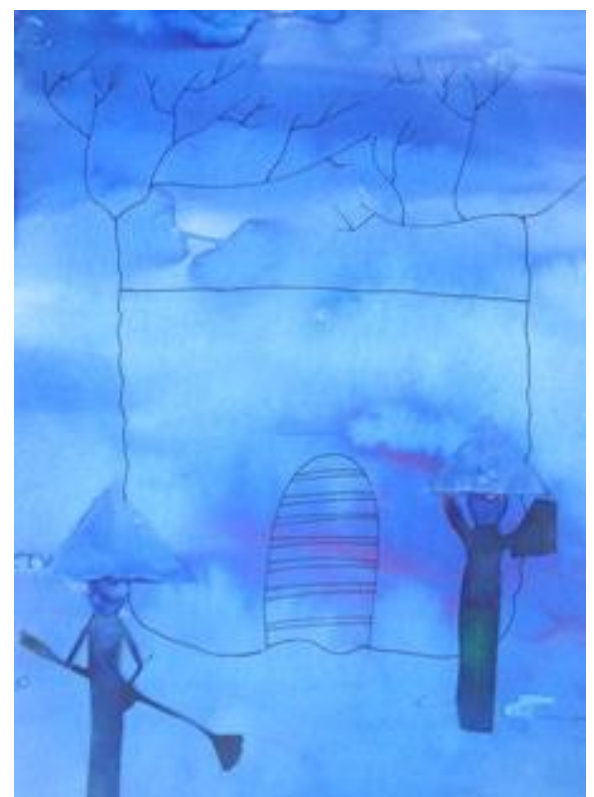

Figura 84

Sem título

Livro - objeto (detalhe), aquarela Dimensões variáveis

2004

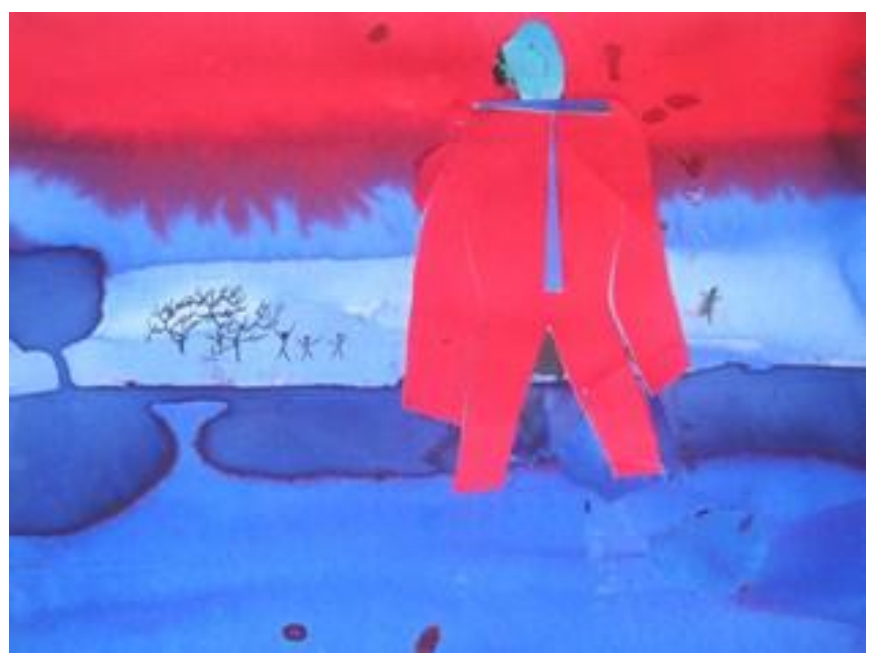

Figura 85

Sem título

Livro - objeto (detalhe), aquarela

Dimensões variáveis

2004 


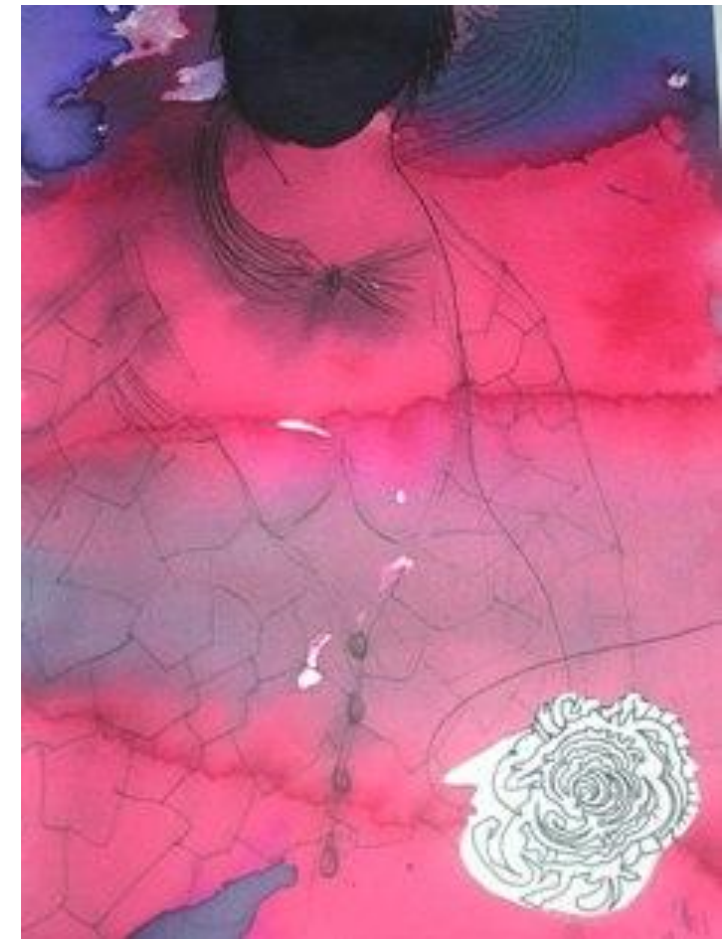

Figura 86

Sem título

Livro - objeto (detalhe), aquarela

Dimensões variáveis

2004

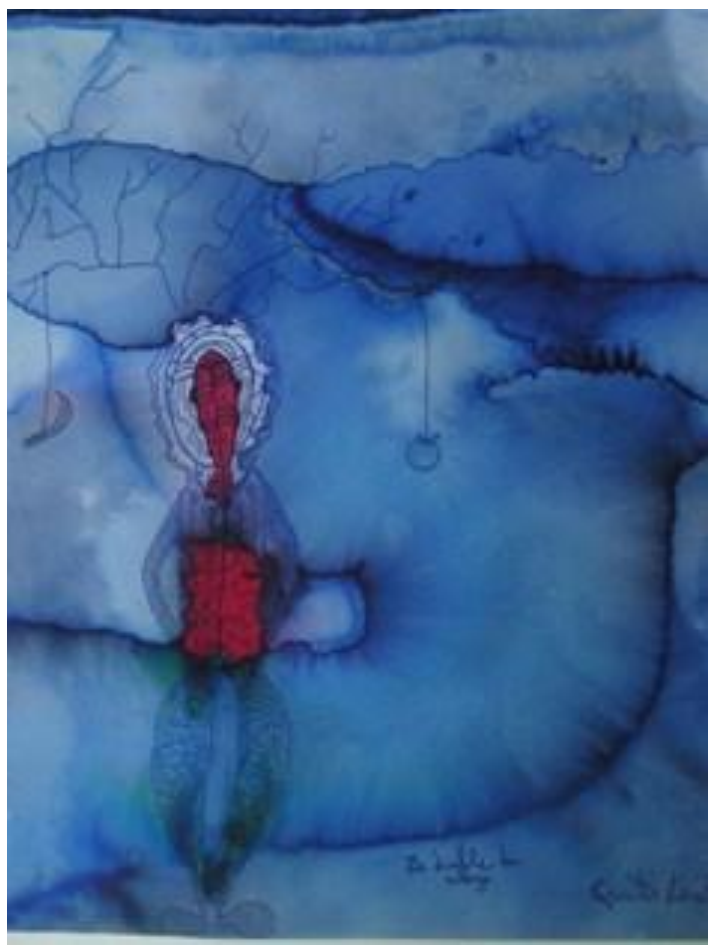

Figura 88

Sem título

Livro - objeto (detalhe), aquarela

Dimensões variáveis

2004

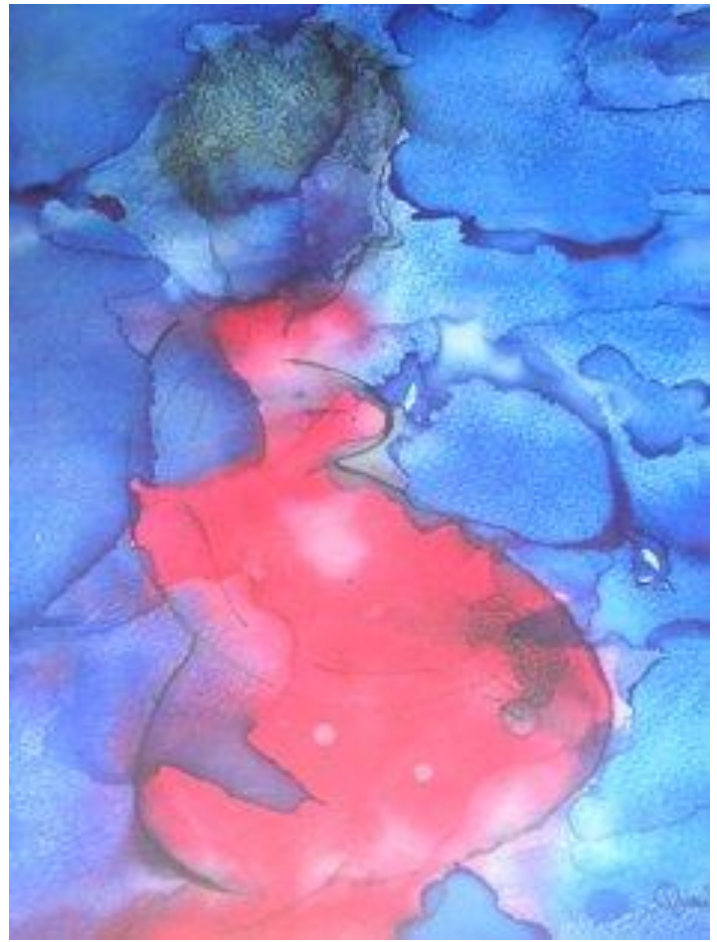

Figura 87

Sem título

Livro - objeto (detalhe), aquarela

Dimensões variáveis

2004

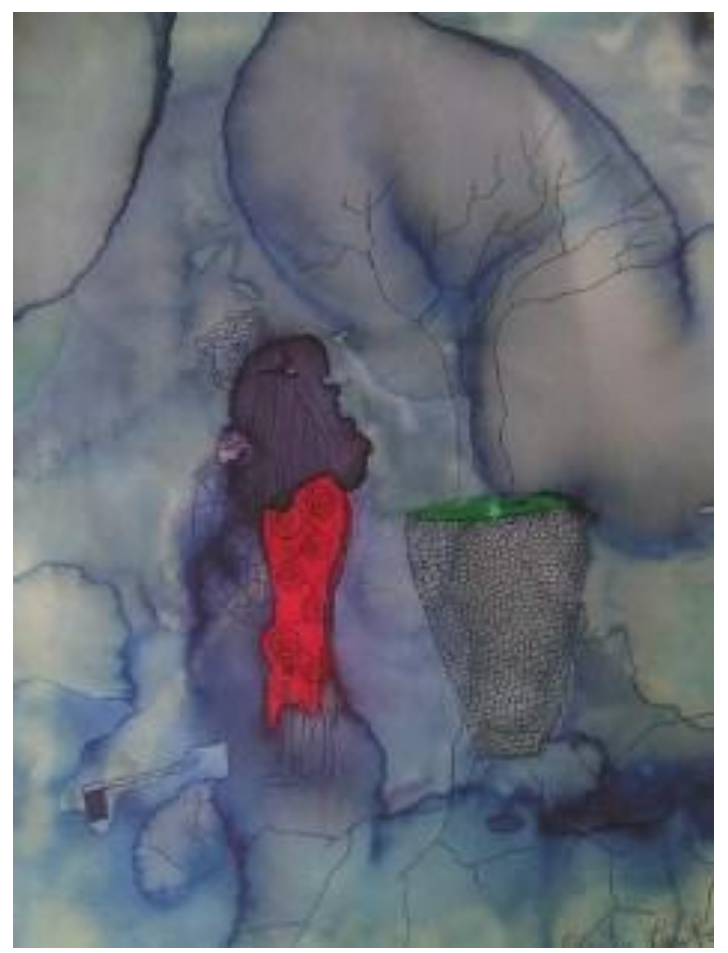

Figura 89

Sem título

Livro - objeto (detalhe), aquarela

Dimensões variáveis

2004 


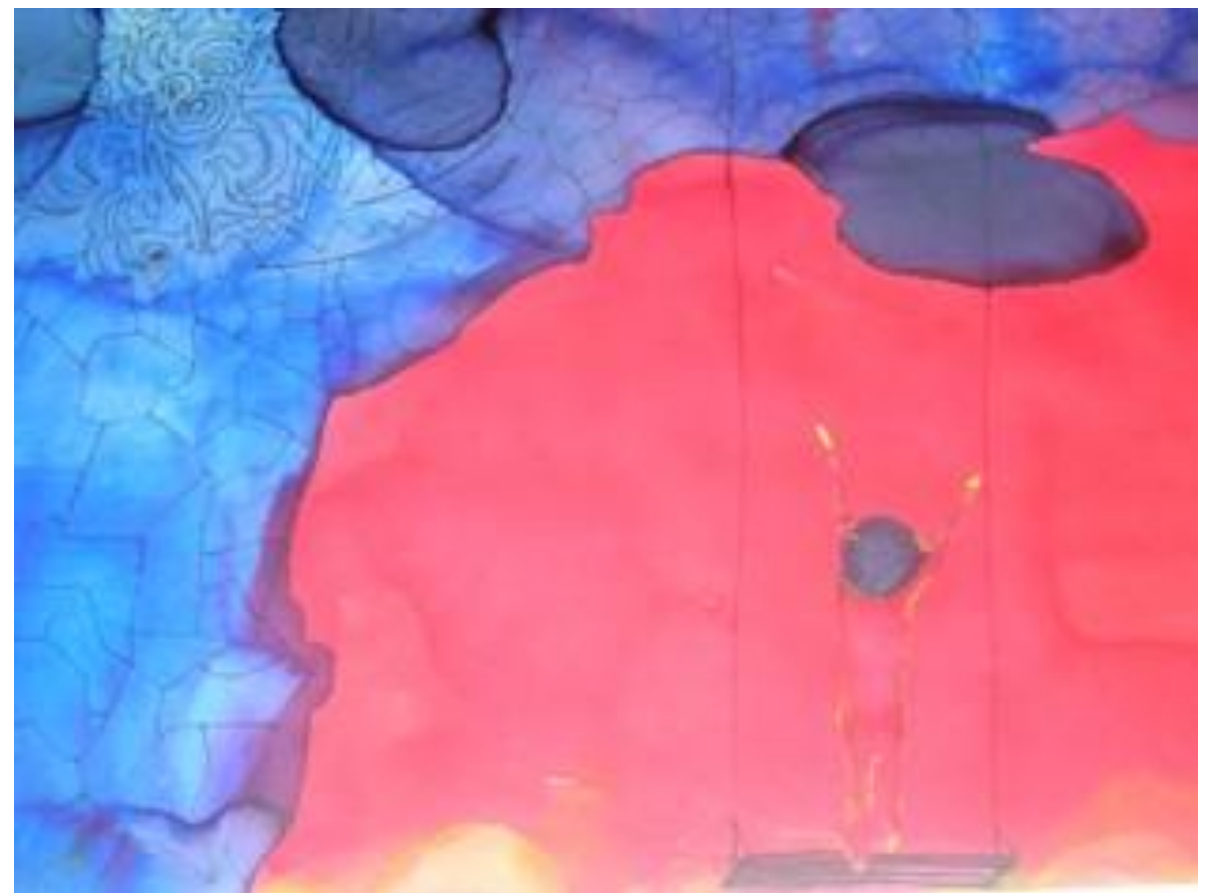

Figura 90

Sem título

Livro - objeto (detalhe), aquarela

Dimensões variáveis

2004

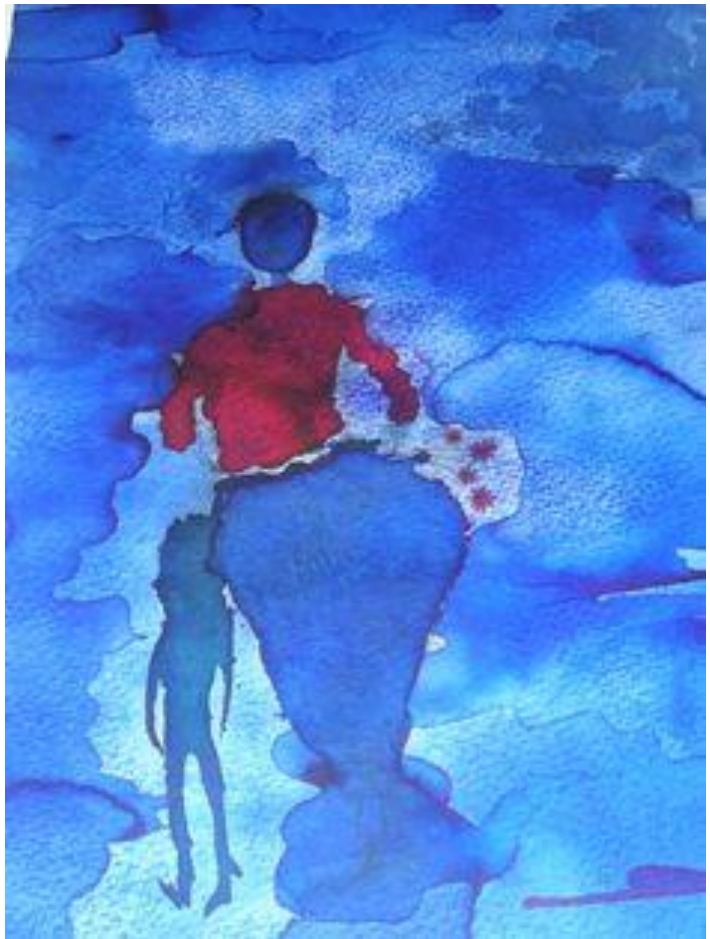

Figura 91

Sem título

Livro - objeto (detalhe), aquarela

Dimensões variáveis

2004

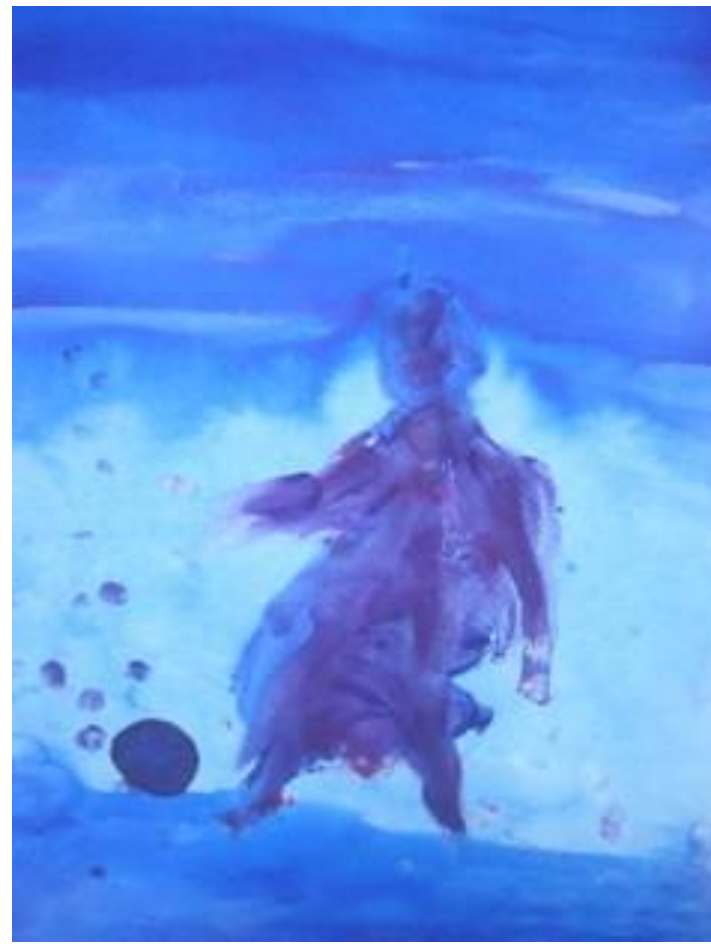

Figura 92

Sem título

Livro - objeto (detalhe), aquarela

Dimensões variáveis

2004 


\subsection{VÂNIA LEMOS}

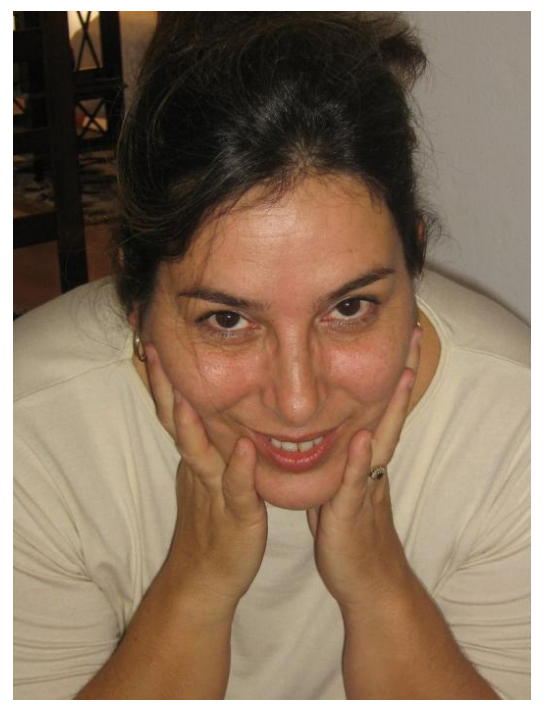

Figura 93

\section{Vânia Lemos}

Vive e trabalha em Maputo, Moçambique

Vânia Lemos, nascida em Maputo, em 1962. Gradua-se em História e Geografia, pela Universidade Eduardo Mondlane. Autodidata, com formação em pintura a óleo, desenho e batique. Exerce a sua atividade profissional como artista plástica na Capital. É membro fundador do Movimento de Arte Contemporânea de Moçambique, MUVART. Participa da exposição Expo-Contemporânea, organizada pelo MUVART, edição de 2004. Sobre a sua linguagem artística comenta "O meu trabalho nas artes plásticas começou por uma busca diversificada e mais tarde o tema foca-se sempre na "MULHER" e seus sonhos." 168

Vânia integra o seleto grupo de mulheres artistas moçambicanas com uma trajetória na pintura. Navega em outras técnicas como a colagem e a aguarela ${ }^{169}$. Trabalha a superfície das suas obras buscando novas organizações dos elementos formais, a técnica adaptando-se ao resultado formal que a artista pretende alcançar.

Vânia participou em 2004 da Coletiva Expo-Arte Contemporânea, no Museu Nacional de Arte, MUSART, em Maputo, a primeira Bienal organizada pelo Grupo MUVART, com um trabalho intitulado A Ambivalência da Aragem, 2004 (Fig. 94). Comenta a artista:

\footnotetext{
${ }^{168}$ Depoimento da artista à autora, via e-mail, 10.out.2011.

${ }^{169}$ Adotamos a grafia moçambicana para a técnica da aquarela.
} 
A sua verticalidade, o seu movimento e o ar que produz são características que, uma vez interpretadas as suas ambivalências e metáforas, podem transmitir uma mensagem em função de uma proposta artística.

Nas minhas mãos, na arte, estão as minhas pisadas e uma das minhas musas é a relação que se estabelece entre as pessoas num determinado espaço físico. ${ }^{170}$

A comunicação é o elemento essencial da obra de arte, e o artista pretende estabelecer este contato com o público. Vânia assume este papel na ação discursiva e na proposta estética na obra A Ambivalência da Aragem, 2004, onde a apropriação do objeto subverte o seu sentido. Destituído do seu significante, o objeto passa a habitar outro universo e o espectador também se desloca.

Sobre o ofício do design, MUNARI recomenda:

Pode ser útil ao projetista saber como se analisam os objetos de produção industrial, a fim de conhecer suas qualidades e defeitos sob todos os aspectos.

Alguns olham um objeto que não conhecem e dizem: gosto ou não gosto, e tudo acaba aí...Não se deve fazer assim quando se olham, observam, analisam os objetos.

Uma coisa é o gosto pessoal, outra são as semelhanças com algo conhecido. Se um designer quiser saber por que os objetos são como são, deve examiná-los sob todos os aspectos possíveis... ${ }^{171}$

Se os conselhos de MUNARI para o designer propõem um olhar atento sobre um objeto, não é diferente a relação estabelecida pela artista em relação a sua obra mesmo que este objeto esteja sendo industrializado.

A apropriação de objetos é identificada por JOLLY como prática comum no território africano, embora seu estudo se detenha no Benin. Comungamos com o autor neste ponto. No caso de Vania Lemos, a artista buscou associar o seu trabalho ao universo cultural moçambicano apropriando-se de um objeto que em si é carregado de valores simbólicos. Tomando como base o papel da história da arte, um de seus objetivos é a codificação de estilos, porém na contemporaneidade este limite é mais extenso do que nas etapas anteriores, dando ao artista uma liberdade maior na experimentação de diversas linguagens e materiais.

\footnotetext{
${ }^{170}$ Expo-Arte Contemporânea, op. cit., 2004, p.48.

${ }^{171}$ MUNARI, Bruno. Das coisas nascem coisas. Martins Fontes: São Paulo, 1998, p.96.
} 


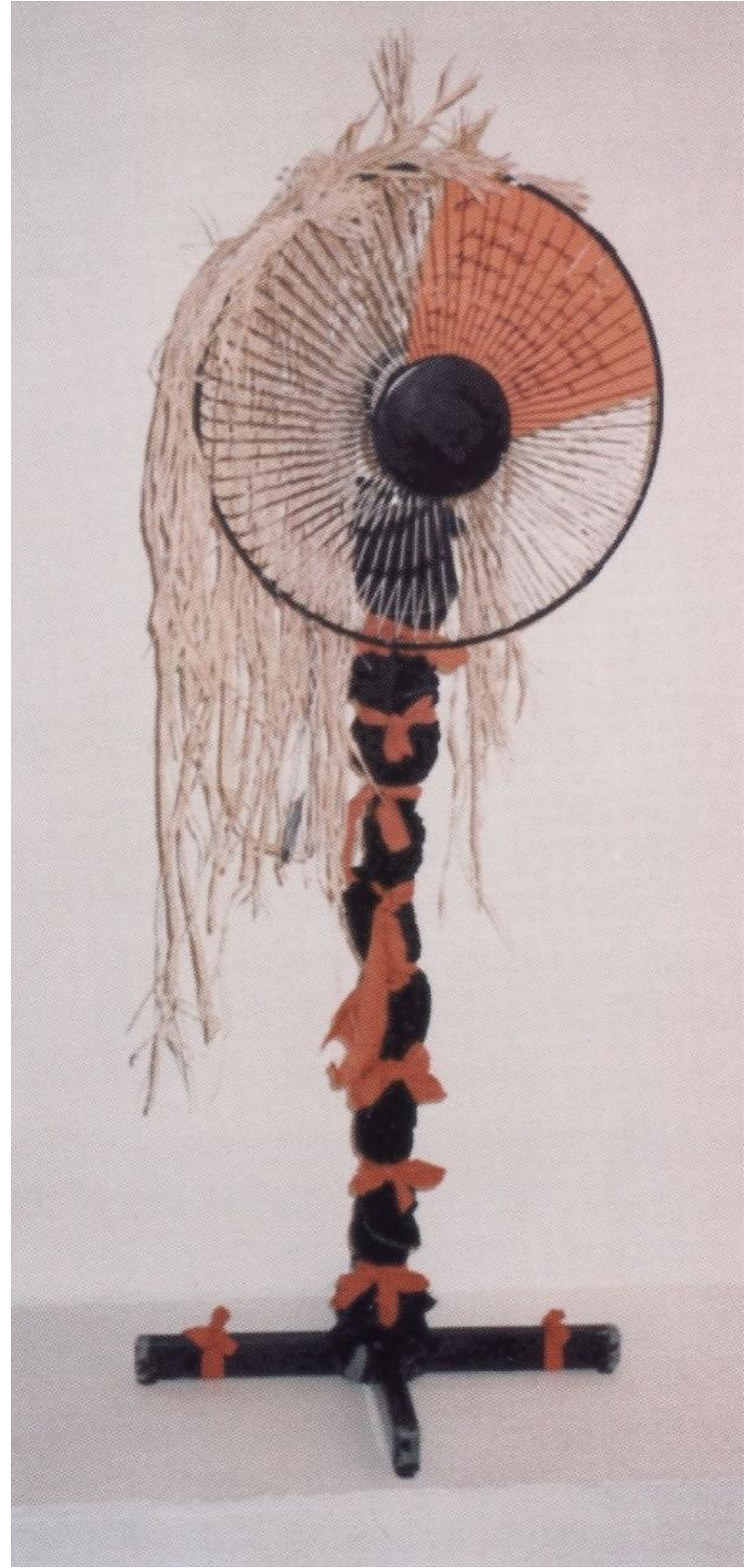

Figura 94 Vânia Lemos

A Ambivalência da Aragem

Ventoinha revestida com materiais diversos

$123 \times 43 \times 48 \mathrm{~cm}$

2004 


\subsection{XAVIER M'BEVE}

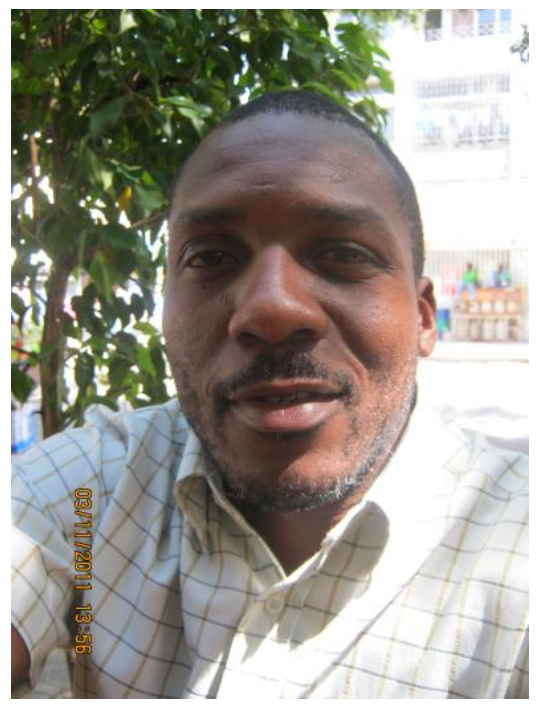

Figura 95

\section{Xavier M' Beve}

Vive e trabalha em Maputo.

Xavier M'Beve é natural de Gaza, distrito de Xai-Xai, em Moçambique. Nascido em 1974, conclui o nível médio em Gráficas na Escola Nacional de Artes Visuais, ENAV, em Maputo. Gradua-se em gravura, no curso de Belas-Artes da Universidade Federal de Minas Gerais, UFMG, Brasil. É membro fundador do Movimento de Arte Contemporânea de Moçambique, MUVART. O artista também trabalha com escultura em madeira de caráter figurativo e realista.

Xavier participou em 2004 na Expo-Arte Contemporânea, no Museu Nacional de Arte, MUSART, em Maputo, a primeira Bienal organizada pelo Grupo MUVART com o trabalho Sem título, 2004 (Fig. 96).

No catálogo da mostra o artista explica:

A unidade e a repetição irregular é relativamente normal, entendendo que a estrutura é de uma concepção funcional, e que por meio dela encontramos formas simples vestidas de material bruto, rusticamente idealizado, e resultando abstractas e de solenidade anti-clássica e irracional. ${ }^{172}$

Xavier apropria-se de um objeto invertendo sua lógica de construção e concepção estética. Incorpora novamente o elemento de que é feito o banco, a madeira, para chamar atenção para a sua estrutura. Neste sentido, opõe-se à concepção artística de Ivan Serra.

${ }^{172}$ Expo-Arte Contemporânea, op. cit., 2004, p.39. 
O banco enquanto objeto pertence a muitas culturas; na África ele é considerado especialmente como símbolo de poder além de atender a funções utilitárias como assento e apoiador de cabeça.

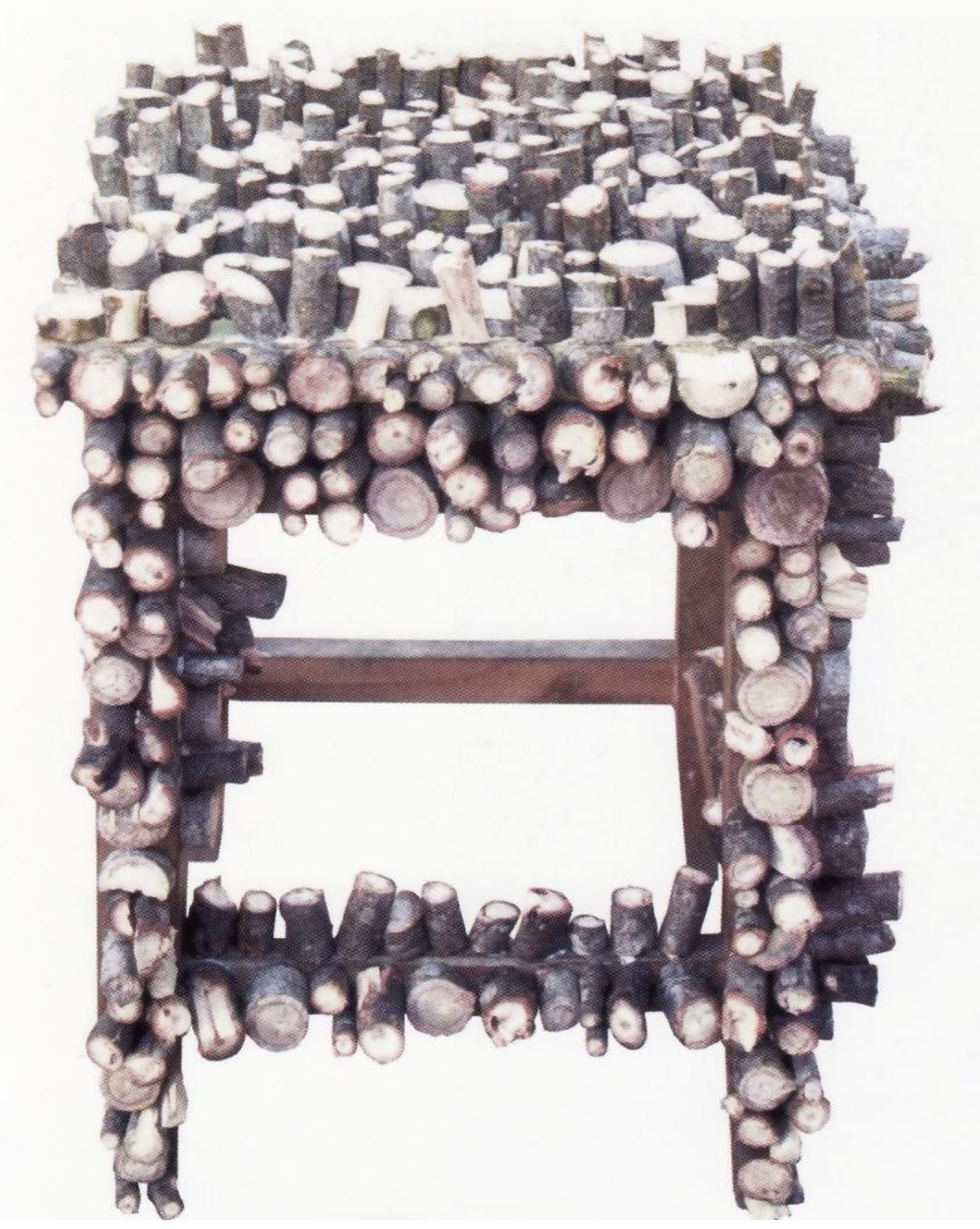

Figura 96 Xavier M'Beve

Sem título (Inacabado)

Banco com galhos

$45 \times 40 \times 40 \mathrm{~cm}$

2004 


\section{CONCLUSÕES}

Do estudo apresentado nesta dissertação podemos inferir conclusões concernentes a diversos aspectos abordados. Essas conclusões são divididas em três grupos, a saber: $1^{\circ}$ As de caráter conceitual, $2^{\circ}$ As metodológicas e $3^{\circ}$ As apoiadas diretamente no estudo proposto.

No que diz respeito aos aspectos conceituais, a análise desenvolvida nos Capítulos 1 e 2 permite concluir que:

(a) A apreciação da arte africana identificada como tradicional está muitas vezes erroneamente definida nos mais diversos campos sejam estes literatos ou expositivos.

(b) A literatura passa pelo mesmo processo de reprodução deste discurso equivocado que nomeia a cultura do outro sob o julgamento etnocêntrico.

(c) A utilização das definições e critérios da arte moderna no século $X X$ para orientar definições e critérios para a arte contemporânea gera uma avaliação superficial e equivocada.

(d) A formação do grupo Movimento de Arte Contemporânea de Moçambique, altera o cenário artístico do país e inicia o debate sobre o estado da arte na contemporaneidade, local e globalmente.

(e) A inserção de outras mídias e abordagens contemporâneas com o convite a outros artistas dá prosseguimento aos objetivos do MUVART e propicia um campo para novos debates em relação à arte contemporânea em Moçambique.

No capítulo 3 os principais tópicos em relação aos aspectos conceituais são:

(f) Novas proposições artísticas

(g) Recontextualização do patrimônio artístico-cultural.

(h) O próprio espaço expositivo que abriga as obras de arte é revisto nas suas esferas sociais e cenográficas a partir destas novas proposições artísticas. 
Metodologicamente, pode-se concluir que:

(a) A história oral é fonte de pesquisa e levantamento dos saberes africanos ainda de forte evidência. A aplicação de entrevistas de cunho aberto e a estada em 2004 para participar do evento, e em 2010 como trabalho de campo foram fundamentais na compreensão e na aproximação da produção cultural e seu entendimento.

(b) O processo de constituição das linguagens contemporâneas e sua prática é resultado do estímulo que os artistas adquirem da sua herança cultural e da sua visão crítica do tempo em que vivem. Esta atividade se autoalimenta com o contato com o outro, sendo este representado por toda a sociedade; ou pelo diálogo entre os seus pares. Além da promoção de cursos de formação cultural e educacional.

(c) A bienal Expo-Arte Contemporânea tem se afirmado ao longo destes seis anos de existência como um espaço de discussão da arte local e global.

(d) A tentativa de adoção e privilégio da literatura moçambicana em diversas áreas provou ser adequada para a compreensão da cultura e dos valores moçambicanos.

No último grupo, as diretamente auferidas pelo estudo:

(a) Nestes seis anos, considerando a data da primeira Bienal Expo-Arte Contemporânea em 2004, o Movimento de Arte Contemporânea de Moçambique, MUVART, vem consolidando este espaço. Os artistas de 37 países distintos atenderam ao chamado e viabilizaram esta iniciativa muitas vezes solicitando apoio de instituições e do Governo em seus próprios países e outras vezes de forma individual, custeando o envio de suas obras e sua estada em Maputo.

(b) O Brasil é um dos principais países a participar sistematicamente deste empreendimento; como resultado deste intercâmbio surgiram palestras, visitas a escolas e ateliês quando da nossa estada em Moçambique em 2004, culminando em um DVD do grupo Percursos ${ }^{173}$ que registrou sua passagem por Maputo. Em 2010, na minha segunda viagem ao país, além das entrevistas ${ }^{174}$ realizadas com os artistas do Movimento de Arte Contemporânea de Moçambique, MUVART, promoveu-se a palestra Arte Afro-brasileira: Diálogos e Convergências, no Museu

\footnotetext{
${ }^{173} \mathrm{O}$ grupo Percursos foi formado por ex-alunos da Escola de Belas Artes, Universidade Federal do Rio de Janeiro, em 2004, composto pelos seguintes artistas brasileiros: Adilson Barbosa, Cristina Bastos, Francisco Edilberto, Isa Bandeira e Marie Brych.

${ }^{174}$ Os artistas entrevistados foram: Anésia Manjate, Carmem Muianga, Gemuce, Jorge Dias, Ivan Serra, Lourenço Pinto, Marcos Muthwuey, Maimuna Adam, Mauro Pinto e Malangatana
} 
Nacional de Arte. Por todo o ano de 2010 a participação em eventos ligados à temática aconteceu tanto quanto em 2011 como desdobramento da pesquisa, o que possibilitou o seu amadurecimento e a consequente divulgação dos artistas e do país.

Assim como CUNHA buscou uma classificação temática dos artistas afrobrasileiros, identificamos alguns pontos de diferenciação em cada um dos integrantes do Movimento de Arte Contemporânea de Moçambique, MUVART, quais sejam:

- $\quad$ Os que utilizam o tema da arte tradicional incidentalmente

- $\quad$ Os que o fazem de modo sistemático e consciente

- $\quad$ Os que se distanciam das matrizes africanas ${ }^{175}$

A detecção destes universos foi delineada pelas obras. Em alguns casos estas classificações foram assumidas pelos próprios artistas quando da explicação do seu trabalho, como é o caso da artista Anésia Manjate, entre outros. A qualidade plástica permanece na essência de todas as obras, independentemente do fato de estarem ou não relacionadas com suas matrizes africanas.

Os artistas moçambicanos colocam paulatinamente o país nas agendas dos eventos culturais internacionais, como é o caso mais recente de Mauro Pinto, indicado ao BES Fhoto $2012 .{ }^{176}$ O fotógrafo foi selecionado com o trabalho "MaputoLuanda-Lubumbashi”; cinco fotografias deste projeto foram apresentadas na ExpoArte Contemporânea, em Moçambique, em 2006. Para o certame todos os selecionados apresentaram novos trabalhos.

A globalização dos artistas moçambicanos depende muito do poder econômico. A facilidade da entrada no mercado de arte é cada vez mais baseada nas potências da Europa e dos EUA, que continuam a olhar para o continente africano da perspectiva do exotismo. Existem porém exceções de eventos de magnitude na área artística como no caso do BES Fhoto. $\mathrm{Na} 29$ a Bienal de São

175 CUNHA, Mariano Carneiro. "Arte Afro-Brasileira". In: ZANINI, W.(Org.). História geral no Brasil. São Paulo:Fundação Moreira Sales, 1983.

${ }^{176}$ Concurso que selecionou quatro participantes; o português Duarte Amaral, a brasileira Rosangella Rennó, o coletivo brasileiro Cia de foto e o moçambicano Mauro Pinto. Está prevista uma exposição em Lisboa, Portugal, em março de 2012, e em São Paulo, Brasil, em junho de 2012, além de 40 mil euros em prêmio para o vencedor do certame. "O Prémio BESphoto, o qual já se firmou como o principal prêmio de arte contemporânea em Portugal, adquire estatuto internacional na sua $7^{\text {a }}$ edição (BESphoto 2011) alargando o âmbito de selecção dos artistas que, a partir desta edição, poderão ser de nacionalidade portuguesa, brasileira e dos Países Africanos de Língua Oficial Portuguesa (PALOP's)." http://www.bes.pt/sitebes/cms.aspx?plg=8A6365B9-87E4-4B59A550-3AB14524A01B, último acesso em: 6 de janeiro de 2012. 
Paulo, em 2010, a delegação africana ainda era bastante tímida: não soubemos de convites aos artistas moçambicanos.

Quando se sublinha a questão econômica, destaca-se que a produção nas mídias contemporâneas é de custo alto e exige tecnologias que os países em desenvolvimento ainda não possuem. A formação é outro fator predominante nesta entrada no mercado da arte internacional, que cada vez mais se profissionaliza, exigindo do artista uma postura diferente da exigida nas décadas anteriores. A inserção nas redes sociais é uma forma contemporânea de divulgação dos trabalhos artísticos, porém este aparato tecnológico e intelectual nem sempre está disponível para os moçambicanos e africanos de modo geral. Como também a obtenção de livros especializados e mesmo de materiais artísticos, o que não tem causado impedimento para a criatividade e para a prática artística moçambicana.

Ao mesmo tempo em que a realidade aponta para cenários desfavoráveis para a criação artística, percebemos intuitivamente um aumento destes profissionais em Moçambique, que agora conta com uma Faculdade na área que deverá incentivar mais jovens a pensar e a produzir arte.

A influência da cultura lusitana na sociedade moçambicana também permanece forte, na língua e no material didático. Verifica-se nos livros adotados pela rede pública de ensino, nos níveis básicos de formação, um percentual considerável de referências lusas, embora contenham indicações sobre aspectos da arte moçambicana e alusões aos artistas do Movimento de Arte Contemporânea de Moçambique, MUVART. Após trinta e seis anos de independência, ainda se vive em situação de Pós-Independência, não apenas econômica como cultural e de busca de afirmação identitária. Em resumo, a independência de Portugal foi consolidada, mas a influência permanece - em diversos setores da sociedade moçambicana, incluindo o psicológico - na relação de subordinação estabelecida pelo colonizador.

Os mais jovens têm a possibilidade de constituir-se como estes novos cidadãos e daí expressar-se como este sujeito social em todas as formas, incluindo a artística. É importante frisar que ao longo da pesquisa constatou-se a necessidade de uma análise dos aspectos positivos que podem advir também do contato com a cultura e a colonização portuguesa, tendo os comentários uma visada crítica, porém unilateral. 
Neste sentido, considerar não ocidentais a arte africana e a arte moçambicana não é um demérito, é um diferencial, pois elas estão relacionadas às raízes e valores de quem as produz.

O Brasil, representado por seus pesquisadores e artistas, tem contribuído neste fórum aberto pelos moçambicanos. Pessoas diferentes fazendo a diferença. Esses profissionais nos propõem pensar e repensar com base em suas obras. E enriquecem-nos! 


\section{REFERÊNCIAS}

ABRAHAMSSON, Hans, Nilsson, Anders. Moçambique em Transição: Um estudo da história de desenvolvimento durante o período 1974-1992. CEGRAF: Maputo, 1994.

ADAM, Maimuna. Between Diaspora and Globalisation: An interpretation of artworks by The Contemporary Art Movement of Mozambique, Faculty of Humanities, University of Pretoria, 2008.

ADAM, Yussuf. Escapar aos Dentes do Crocodilo e Cair na Boca do Leopardo: Trajetória de Moçambique Pós-Colonial (1975-1990), Maputo, Edição Promédia, 2006.

AGUESSY, Honorat; DIAGNE, Pathé. Introdução à Cultura Africana. Lisboa: Edições 70, (s/1):Unesco, (Biblioteca de Estudos Africanos), 1977.

ALBERTI, Leon Battista. Da Pintura. Campinas, São Paulo:Unicamp,2009.

APPIAH, Kwame Anthony. Na casa de meu pai. A África na filosofia da cultura. Rio de Janeiro: Contraponto, 1997.

ARGAN, Giulio Carlo. Arte Moderna. São Paulo: Companhia das Letras, 1992.

Arte e Crítica de Arte. Lisboa: Estampa, 1995.

ASSOCIAÇÃO BRASILEIRA DE NORMAS TÉCNICAS. NBR 10520: informação e documentação: citações em documentos: apresentação. Rio de Janeiro, 2002.

BALOGUN, Ola. Forma e expressão nas artes africanas. In: ALPHA, Sow; BALOGUN, Ola; AGUESSY, Honorat; DIAGNE, Pathé. Introdução à Cultura Africana. Lisboa: Edições 70, (s/1):Unesco, (Biblioteca de Estudos Africanos), 1977.

BANDEIRA, Isa. Arte tradicional Moçambicana: Os Macondes, Os Macuas, Os Tsongas e Os Nyngwes. Congresso Internacional NEHO 20 anos: História oral, Identidade e Diversidade, Universidade de São Paulo, São Paulo, 2011.

BANES, Sally. Greenwich, avant-garde, performance e o corpo efervescente. Rio de Janeiro:Rocco, 1999.

BARGNA, Ivan. Visual Encyclopedia of Art. Arte Africana. Florença:Scala, 2010.

BATTOCOCK, Gregory. A Nova Arte. São Paulo:Perspectiva, 2002.

BAUDRILLARD, Jean. Power Inferno. Porto Alegre:Sulina, 2003.

BENJAMIN, Walter. Magia e Técnica, arte e política: ensaios sobre literatura história da cultura. São Paulo:Brasiliense, 1994 (Obras escolhidas, vol. 1) 
BERGH, Lucia Van den. Porque prevaleceu a paz, Moçambicanos respondem. Editora Annick Osthoff, Parlamentares Europeus com África, AWEPA. Moçambique, s/d.

BOSI, Alfredo. Reflexões sobre a Arte. São Paulo:Ática, 2008.

BOURRIAUD, Nicolas. Pós-Produção: como a arte reprograma o mundo contemporâneo. São Paulo: Martins Fontes, 2009.

CABAÇO, José Luís. Moçambique Identidade, colonialismo e libertação. São Paulo:UNESP, 2009.

CANÊDO, Letícia Bicalho. A Descolonização da Ásia e da áfrica: processo de ocupação colonial: transformações sociais nas colônias: os movimentos de libertação, Atual:São Paulo,Campinas, Universidade Estadual de Campinas,1985.

CARVALHO, Rui Moreira. Compreender África, teoria e práticas de gestão. Rio de Janeiro:Editora:FGV, 2005.

CAUQUELIN, Anne. Arte Contemporânea. Martins Fontes:São Paulo, 2005 . Teoria da Arte. Martins Fontes:São Paulo, 2005

CESAR, Miguel. Murmúrios e outros falares. Maputo:Marimbique, 2008.

CHIPP, H.B. Teorias da arte moderna. São Paulo:Martins Fontes, 1996.

COELHO, João Paulo Borges. As Duas Sombras do Rio, Maputo:Ndjira, 2003.

COHEN, Renato. Performance como linguagem. São Paulo:Perspectiva, 2004.

CONRAD, Joseph. Coração das Trevas, São Paulo: Companhia das Letras, 2008.

COSTA, Alda. Arte e Museus em Moçambique - Entre a construção da nação e o mundo sem fronteiras. Tese de Doutoramento, Universidade de Lisboa, Portugal, 2005.

COSSA, Lourenço Eugenio. Línguas Nacionais no Sistema de Ensino para o Desenvolvimento da Educação em Moçambique, Tese de Mestrado, Universidade Federal do Rio Grande do Sul, Faculdade de Educação, Rio Grande do Sul, 2007.

COSTA, Alda, JOSÉ, Benites, Lucas, (Org.). Percursos e Olhares, Uma Introdução à Arte em Moçambique, EPM-CELP, 2008.

COSTA, Sérgio Francisco. Método Científico, os caminhos da investigação. São Paulo:Harbra, 2001.

COTTON, Charlotte. A Fotografia como Arte Contemporânea. São Paulo:Martins Fontes, 2010. 
CUNHA, Mariano Carneiro. Arte Afro-Brasileira. IN: Zanini, W. (Org.). História Geral no Brasil. São Paulo:Fundação Moreira Sales, 1983.

CURY, Marília Xavier. Exposição, concepção, montagem e avaliação. São Paulo:Annablume,2005.

DANTO, Arthur C. Após o fim da Arte: A Arte Contemporânea e os Limites da História. São Paulo: Odysseus Editora, 2006.

DIAS, Inês de Almeida e Costa, DIAS, POR AQUI, Projecto para uma exposição, vol.II, Tese de Mestrado em Estudos Curatoriais, Universidade de Lisboa, Faculdade de Belas Artes, Portugal , 2006.

DIAS, Jorge. Os Macondes de Moçambique, Aspectos Históricos e Econômicos, vol. I. Junta de Investigações do Ultramar, Centro de Estudos de Antropologia cultural, Lisboa, 1964.

DIAS, Jorge. DIAS, Margot. Os Macondes de Moçambique, Aspectos Históricos e Econômicos, vol. II. Junta de Investigações do Ultramar, Centro de Estudos de Antropologia cultural, Lisboa, 1964.

FARTHING, Stephen (Editor geral). Tudo sobre Arte, Os movimentos e as obras mais importantes de todos os tempos, Sextante:Rio de Janeiro, 2011.

FAUVET, Paul, MOSSE, Marcelo. É proibido pôr algemas nas palavras. Carlos Cardoso e a Revolução Moçambicana, Maputo: Nadjira, 2003.

FONSECA, Dagoberto José da, BENTO, Maria Aparecida Silva. África Desconstruindo Mitos, São Paulo:Secretaria de Educação Municipal de São Paulo, CEERT- Centro de Estudos das Relações de Trabalho e Desigualdade, 2008.

FRIEDMANN, Georges. O Trabalho em Migalhas. São Paulo:Perspectiva, 1983.

FRUTIGER, Adrian. Sinais e Símbolos. Martins Fontes:São Paulo, 2001.

GLUSBERG, Jorge. A Arte da Performance. Perspectiva:São Paulo, 2003.

GOMBRICH, E. H. A História da Arte. Rio de Janeiro:LTC, 2008.

GOMÉZ, Miguel Buendía. Educação Moçambicana, História de um processo: 1962-1984. Ed. Livraria Universitária, Eduardo Mondlane, Maputo, Moçambique, 1999.

GONÇALVES, Rebollo Lisbeth. Entre Cenografias, o Museu e a Exposição de Arte no Século XX. São Paulo: Editora da Universidade de São Paulo/Fapesp, 2004.

GREENBERG, Clement. Estética Doméstica. São Paulo:Cosac \& Naify, 2002.

GUERRA, Marco Antonio, MATTOS, Paula de Vincenzo Fidelis Belfort. Indústria 
Cultural. São Paulo: USJT, 2008.

GULLAR, Ferreira. Argumentação Contra a Morte da Arte. Rio de Janeiro:Revan, 1993.

HALL, Stuart. A identidade cultural na pós-modernidade. 6을 Rio de Janeiro:DP\&A, 2001.

JOLLY, André. A arte contemporânea e o Benin In: África, Núcleo Interdisciplinar do Imaginário e Memória - NIME, Laboratório de Estudos do Imaginário, LABI, Instituto de Psicologia da Universidade de São Paulo, IP-USP, Ano X, $\mathrm{n}^{\circ}$ 10, 2004/2005.

JUNOD, Henri. Usos e Costumes dos Bantu, tomo II: Vida Mental, Editor Arquivo Histórico de Moçambique, Maputo, 1996.

KI-ZERBO, Joseph. História da África Negra, vol. I. Portugal: Publicações EuropaAmérica Itda., 2009.

América Itda., 2002.

História da África Negra, vol. II. Portugal: Publicações Europa-

Para quando a África? Entrevista com René Holenstein. Rio de Janeiro:Pallas, 2009.

KLEE, Paul. Sobre a arte moderna e outros ensaios. Rio de Janeiro: Jorge Zahar Editores, 2001.

KOETZLE, Hans-Michael. Photo Icons, petite histoire de la photo. Singapura:Taschen, 1996.

KRAUSS, Rosalind. Caminhos da Escultura Moderna. São Paulo, Martins Fontes 1998.

KUBRUSLY, Cláudio A. O que é fotografia. São Paulo:Brasiliense, 2006.

MAIA, Alone, Antonio. Saúde e Doença na Cultura Nyungwe: Um olhar Antropológico-Teológico, Mestrado em Teologia Sistemática, Pontifícia Universidade Católica de São Paulo, PUC/SP, São Paulo, 2011.

MANDELA, Nelson. Nelson Mandela conversas que tive comigo. Rio de Janeiro:Rocco, 2010.

MARCUSE, Herbet, Eros e Civilização. Uma Interpretação filosófica do Pensamento de Freud. Rio de Janeiro: Zahar Editores, 1978.

MARTÍNEZ, Francisco Lerma. O povo Macua e a sua cultura: Análise dos valores culturais do povo Macua no Ciclo Vital, Maúa, Moçambique 1971-1985. Maputo: Paulinas, 2ª edição, 2008. 
MARTINS, Itajahy. Gravura arte e técnica. São Paulo:Laserprint: Fundação Nestlé de Cultura, 1987.

M'BOKOLO, Elikia. África Negra, História e Civilizações, tomo I (até o século XVIII). Salvador: EDUFBA; São Paulo: Casa das Áfricas, 2009

. África Negra, História e Civilizações do Século XIX aos nossos dias, tomo II. Portugal, Lisboa: Colibri, 2007

MEIGOS, Filimone. Mozambique meu corpus quantum, Maputo:Marimbique, 2009.

MORALEZ, Rafael. Boiando em Moçambique, São Paulo: Balão, 2011.

MOULIN, Raymonde. O Mercado da Arte, mundialização e novas tecnologias. Porto Alegre, RS: Zouk, 2007.

MUNANGA, Kabenguele. O que é Africanidade. In: Vozes da África. Biblioteca entre livros, São Paulo: Seguimento Ediouro, Ed.6, p. 8, (não há referência ao ano da edição).

A dimensão estética da arte negro-africana tradicional. In: AJZENBERG, Elza. (Org.). Arteconhecimento. São Paulo: MAC-USP, 2004.

MUNARI, Bruno. Das coisas nascem coisas. São Paulo:Martins Fontes, 1998.

NEVES, Angelina. Viagens com a cabaça mágica, Nampula, vol.4, Ed.Coopimagem, Maputo, Moçambique, 2002.

OBRIST. Hans Ulrich. Uma breve história da curadoria. São Paulo:Bei Comunicação, 2010.

O'DOHERTY, Brian, No interior do Cubo Branco, Martins Fontes:São Paulo, 2007.

ORWELL, George. 1984. Companhia das Letras: São Paulo, 2009.

PAZ, Otavio. Marcel Duchamp ou o Castelo da Pureza. São Paulo:Perspectiva, 1977.

PERNIOLA, Mario. Os Situacionistas: 0 movimento que profetizou a "Sociedade do Espetáculo". São Paulo:Annablume, 2009.

PINHO, Diva Benevides. A Arte Como Investimento, A Dimensão Econômica da Pintura. São Paulo: Nobel, 1988.

RAMOS, Alexandre Dias. (Org) Sobre o ofício do curador. Porto Alegre, RS: Zouk, 2007.

RICHARD, André. A crítica de Arte. São Paulo: Martins Fontes, 1988. 
ROCHA, Aurélio. Moçambique História e Cultura, Texto Editores, Moçambique, 2006.

Associativismo e Nativismo em Moçambique. Contribuição pra o Estudo das Origens do Nacionalismo Moçambicano, Texto Editores, Moçambique, 2006.

RUSH, Michael. Novas mídias na arte contemporânea. São Paulo:Martins Fontes, 2006.

SÁ, Elida. BRITO, Isa. O Planejamento como instrumento da construção da cidadania. São Paulo:Revista de Direito Ambiental, no7, jul/set, 1997.

SAATCHI, Charles. ? London:Phaidon, 2010.

SALUM, Marta Heloisa Leuba. África: Culturas e Sociedades, Guia temático para professores. Museu de Arqueologia e Etnologia da Universidade de São Paulo, São Paulo, 2008.

SERRA, Carlos, História de Moçambique, Vol. I. In SERRA, Carlos (dir.), Maputo: Departamento de História, Universidade Mondlane, 2000.

SILVA, Alberto da Costa e. A Enxada e a Lança. A África antes dos portugueses, Rio de Janeiro: Nova Fronteira, 2006.

SILVA, Dilma de Melo, CALAÇA, Felix Maria Cecília. Arte Africana e AfroBrasileira, São Paulo: Terceira Margem, 2006.

SILVA, Fernando Pedro. Arte Pública diálogo com as comunidades. Belo Horizonte: C/Arte, 2005.

SONTAG, Susan. Sobre Fotografia. São Paulo: Companhia das Letras, 2004.

SOPA, António, RUNGO, Bartolomeu. Maputo - Roteiro Histórico Iconográfico da Cidade. Ed. Centro de Estudos Brasileiros da Embaixada do Brasil, Maputo, 2006.

SOUSA, Victor. O Sortilégio Estético de Victor Sousa, Maputo:Alcance Editores, 2010.

SOUZA, Marina de Mello. África e Brasil Africano. Ática: São Paulo, 2007.

STANGOS, Nikos. Conceitos da Arte Moderna, Rio de Janeiro: Jorge Zahar, 2000.

SUANO, Marlene. O que é Museu. São Paulo: Brasiliense, 1986.

TRIGO, Luciano. A grande feira - Uma reação ao vale-tudo na arte contemporânea. Civilização Brasileira:Rio de Janeiro, 2009.

VELOSO, Helena, Almeida, Luís de. Educação Visual, Plural Editores, Maputo, Moçambique, s/d. 
WOLFE, Tom. A palavra pintada, Porto Alegre:L\&PM, 1987.

\section{CATÁLOGOS}

Catálogo A Máquina que queria voar. Uma Selecção da Colecção de Arte TDM. Maputo: Ciedima, 2007.

Catálogo Artistas de Moçambique, Percursos Recentes, Lisboa, 2007.

Catálogo Espaços de Hoje: desafios e limites, Bienal TDM'09, Maputo:TDM, 2009.

Catálogo Expo-Arte Contemporânea, Maputo, Moçambique, 2004.

Catálogo Expo-Arte Contemporânea, Maputo, Moçambique, 2006.

Catálogo Expo-Arte Contemporânea, Maputo, Moçambique, 2008.

Catálogo Expo-Arte Contemporânea, Maputo, Moçambique, 2010.

Catálogo Mudaulane, exposição individual, Maputo:Cedima, 2005.

Catálogo Refúgios Invioláveis, Gemuce, Maputo:Ciedima, 2009.

Catálogo Réplica e Rebeldia: Angola, Brasil, Cabo Verde e Moçambique, Lisboa: Instituto Camões, 2006.

LE GALL, Löic. Jorge Dias. Les Carnets de la création, Éditions de l'oeil, Mozambique, 2008.

LE GALL, Löic. Mauro Pinto. Les Carnets de la création, Éditions de l'oeil, Mozambique, 2008.

\section{PERIÓDICO}

O PAís http://www.opais.co.mz

NORDINE, Amin. O que não é arte e que pode ser considerado como tal. Jornal Zambeze 19.ago.2010, p.31.

Disponível em:

http://maimunaadam.wordpress.com/press/

Acessado em: 9 novembro de 2010.

Revue Noire: http://www.revuenoire.com/ 


\title{
SITES
}

\author{
África e arte africana (sobre) \\ http://alexandrepomar.typepad.com/ \\ http://www.antoniopintoribeiro.com/cms/ \\ http://www.artafrica.info/index.php \\ http://www.casadasafricas.com.br \\ http://www.dakart.org \\ http://www.fundacaoplmj.com/index.php \\ http://www.instituto-camoes.org.mz/ \\ http://ma-schamba.com/
}

\author{
África Remix \\ Disponível em: \\ http://www.casadasafricas.org.br/img/upload/609301.pdf \\ Acessado em: 03 julho 2011.
}

Bienal de Arte Africana Contemporânea de Dacar.

Disponível em:

http://www.dakart.org/2010/spip.php?rubrique5

Acessado em: 20 Setembro 2011.

\section{Bienal de Joanesburgo}

Disponível em:

http://www.universes-in-universe.de/car/africus/english.htm

Acessado em: 20 setembro 2011.

CENTRO DE DOCUMENTAÇÃO E FORMAÇÃO FOTOGRÁFICA

http://www,cdff.virb.com/index

\section{Desenhos de Malangatana}

Disponível em:

http://ma-schamba.blogspot.com/2007/06/desenhos-de-prisao-exposicao-de.html, Acessado em: novembro de 2011.

http://2.bp.blogspot.com/ PshaZq1PQ9s/RmkZTTQd0nl/AAAAAAAABRk/8olHnexMo NY/s1600-h/Malangatana4.jpg,

Acessado em: novembro de 2011.

DIAS, Jorge, "Lugares da arte e Arte nos lugares"

O País, 01 outubro de 2010

Disponível em:

http://www.opais.co.mz/index.php/opiniao/134-jorge-dias/9912-lugares-da-arte-earte-nos-lugares.html, acessado em: 19 março 2011.

Encontros africanos de fotografia, Bamaco, Mali.

Disponível em:

http://www.rencontres-bamako.com/francais/les-rencontres/historique/?lang=fr

Acessado em: 12 setembro 2011. 


\section{ESTAÇÃO CENTRAL DOS CAMINHOS DE FERRO CFM}

http://www.cfmnet.co.mz/newsweek.html

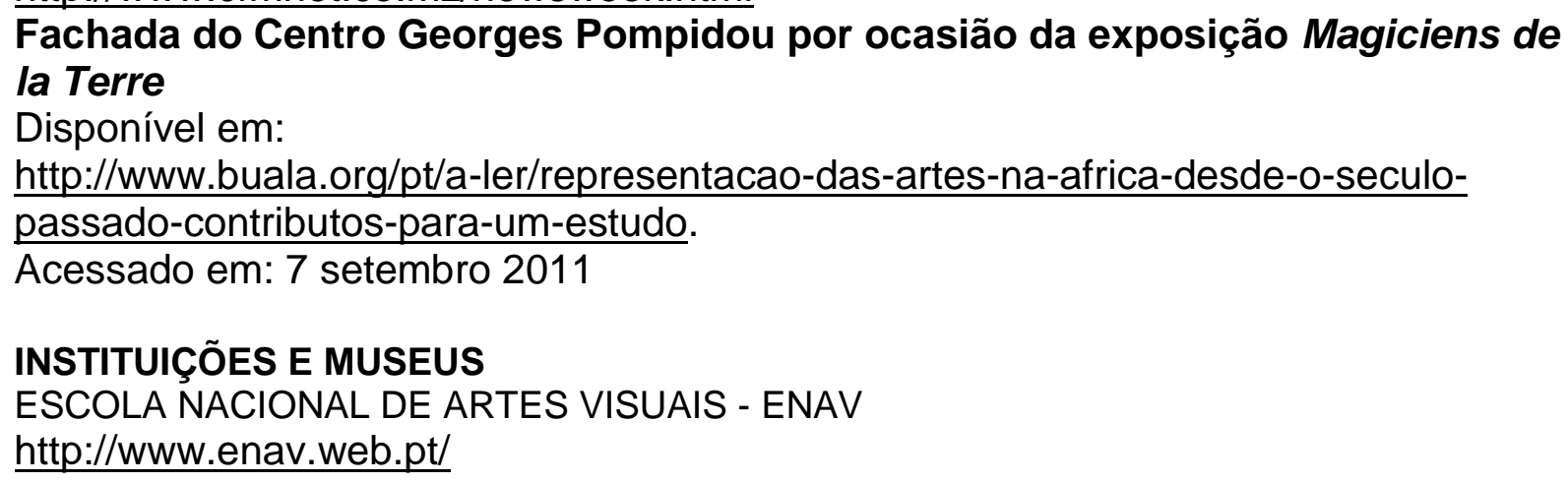

http://www.buala.org/pt/a-ler/representacao-das-artes-na-africa-desde-o-seculopassado-contributos-para-um-estudo.

Acessado em: 7 setembro 2011

INSTITUIÇÕES E MUSEUS

ESCOLA NACIONAL DE ARTES VISUAIS - ENAV

http://www.enav.web.pt/

Instituto do Patrimônio Histórico e Artístico Nacional (IPHAN), Brasil

Disponível em:

http://www.brasil.gov.br/sobre/cultura/patrimonio/patrimonio-material-e-imaterial

Acessado em: 26 setembro 2011.

KULUNGWANA http://www.kulungwana.org.mz

Localização geográfica da República de Moçambique.

Disponível em:

http://www.ine.gov.mz,

Acessado em: 26 setembro 2011.

\section{MUVART}

http://muvartmoz.blogspot.com/

http://viajar.sapo.mz/cultura/artigo/250

http://www.artafrica.info/index.php

http://www.funacaoplmi.com

http://centroculturaldelagos.wordpress.com/

NÚCLEO DE ARTE

http://pt-pt.facebook.com/nucleodarte

http://nucleodarte.com/

http://nucleodarte.blogspot.com/

http://twitter.com/\#!/nucleodarte

\section{Reinata Sadimba}

Disponível em:

http://www.ccfmoz.com/

Acessado em: agosto de 2011.

RICARDO, Celso. Um cemitério no Museu de Arte

O País, 21 de agosto de 2010, p.22.

Disponível em:

http://maimunaadam.wordpress.com/press/

Acessado em: 10 novembro de 2010.

Vídeo O Lar/Home, Maimuna Adam

Disponível em: 
http://www.youtube.com/watch?v=EOazWCZxUeg

ZAMPARONI, Valdemir. A África e os estudos africanos no Brasil: Passado e Futuro. Disponível em:

http://www.nacaomestica.org/zamparoni a africa e os estudos africanos.htm Acessado em: 28 agosto 2010.

\section{ARTISTAS FACEBOOK}

IVAN SERRA

JORGE DIAS

LOURENÇO E. COSSA

MAIMUNA ADAM

MAURO PINTO

POMPILIO HILÁRIO GEMUCE

QUENTIN LAMBERT

VANIA LEMOS

XAVIER MBEVE

PÁGINAS DOS ARTISTAS 


\section{ANEXOS}

ANEXO A "CERTIDÃO DE CRIAÇÃO DO MOVIMENTO DE ARTE CONTEMPORÂNEA DE MOÇAMBIQUE, MUVART"

ANEXO B MANIFESTO DO MOVIMENTO DE ARTE CONTEMPORANEA DE MOÇAMBIQUE

ANEXO C "ENTREVISTA COM FILIMONE MEIGOS"

ANEXO D "PRINCIPAIS CENTROS DE CIRCULAÇÃO E DIVULGAÇÃO DA ARTE" 


\section{ANEXO A}

MUVART

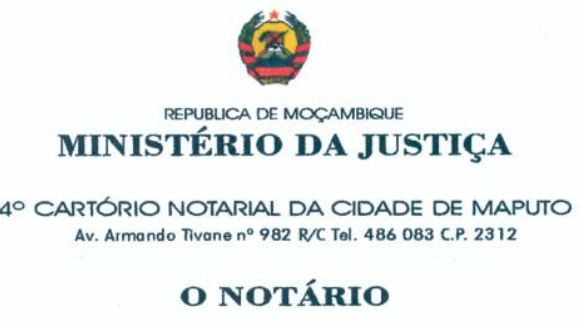

1AIME BULANDE GUTA

Técnico Superior dos Registos e Notariado N1

\section{CERTIDÃo}

Eu abaixo assinado Ajudante deste Cartório certifico que :

1. A presente certidão composta por..........................

só face, foi extraida da escritura lavrada de folhas. ....... Uiskle............ folhas.

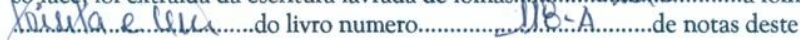

Cartório.

2- Está conforme o original.

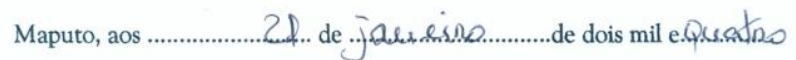

O AJUDANTE

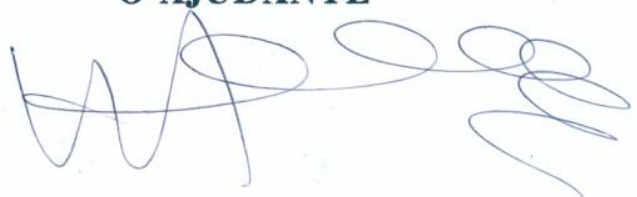

Art $18 \mathrm{n}^{2} 1 \ldots . . . . . \quad 30.000 .00$

Art $^{2} 18 \mathrm{n}^{2} 2 \ldots \ldots . . .75000 \mathrm{~W}$

Soma...... Jo.5000,

Selo de Verba.

Cofre...

Despesas.

16.50010

Total. 
ASSOCIAÇÃO

No dia vinte de Janeiro de dois mil e quatro, nesta cidade de Maputo e no Quarto Cartório Notarial, perante mim JAIME BULANDE GUTA, Mestrado em Ciências Jurídicas e Notário do referido Cartório, compareceram como outorgantes:

\section{PRIMEIRO}

POMPÍlLO HILÁRIO, casado com Élia Alberto Manjate, sob o regime de comunhão de bens adquiridos, natural de Quelimane, de nacionalidade Moçambicana, residente nesta cidade, titular do Bilhete de Identidade numero:110081211Z, de três de Maio do ano dois mil e dois, emitido pelo Arquivo de Identificação Civil do Maputo, que neste acto outorga por si e na qualidade de procurador, do senhor: QUENTIM LAMBERT, casado com Isabel Paulino Lambert, sob o regime de comunhão de bens, natural de França, de nacionalidade Francesa, e residente em Maputo, portador do Dire número: $8600 \mathrm{~A}$, com autorização de residência temporária numero: 06082399 de onze de Dezembro de dois mil e um, emitido pela Direcção Nacional de Migração em Maputo, com poderes bastantes para o acto, o que certifico da procuração outorgada na cidade de Paris- França, na Embaixada da República de Moçambique, perante Carlos Manuel da Costa, Primeiro Secretário e Responsável da Secção Consular da mesma Embaixada, datada de três de Dezembro do ano dois mil e três, que me apresentou e arquivo, e faz parte integrante deste processo.

\section{SEGUNDO}

XAVIER JOSÉ MARIA BEVE, casado, com Anna Cécilia de Carvalho Rocha Beve, sob o regime de comunhão de bens adquiridos, natural de Xai-Xai-Gaza, de nacionalidade Moçambicana, e residente em Maputo, portador do Bilhete de Identidade número:110055611G, de vinte e nove de Outubro de dois mil e dois, emitido pelo Arquivo de Identificação Civil de Maputo. 
TERCEIRO

CARMEN MARIA MUIANGA, solteira, maior, natural de Maputo, de nacionalidade Moçambicana, e residente nesta cidade, portadora do Bilhete de Identidade número:7101432 de vinte e três de Setembro de mil novecentos e noventa e nove, emitido pelo Arquivo de Identificação Civil de Maputo.

\section{QUARTO}

ANÉSIA ZEFANIAS FILIPE MANJATE, solteira, maior, natural de Maputo, de nacionalidade Moçambicana, e residente nesta cidade, portadora do Bilhete de Identidade número: $11025478 \mathrm{~F}$, de vinte de Julho de dois mil e um, emitido pelo Arquivo de Identificação Civil de Maputo.

\section{QUINTO}

CELESTINO BENTO MONDLANE, solteiro, maior, natural de Maputo, de nacionalidade Moçambicana e residente em Maputo, portador do Bilhete de Identidade número:110195888J, de nove de Janeiro de dois mil e um, emitido pelo Arquivo de Identificação Civil de Maputo.

\section{SEXTO}

LOURENÇO EUGENIO COSSA, solteiro, maior, natural de Maputo, de nacionalidade Moçambicana, e residente nesta cidade, portador do Bilhete de Identidade número 110214994Y, de vinte e seis de Março de dois mil e um, emitido pelo Arquivo de Identificação Civil de Maputo.

\section{SÉTIMO}

MARCOS BONIFÁCIO MUTHEWUYE, solteiro, maior, natural de Vila de Manjacaze-Gaza, de nacionalidade Moçambicana, e residente nesta cidade, portador do Bilhete de Identidade número:110232427M, de vinte de Junho de dois mil e um, emitido pelo Arquivo de Identificação Civil de Maputo. 


\section{OITAVO}

IVAN CÉSAR DOS SANTOS SERRA, casado com Vânia Andrea Rosário dos Santos Serra, sob o regime de comunhão de bens adquiridos, natural de Maputo, de nacionalidade Moçambicana e residente nesta cidade, portador do Bilhete de Identidade número: 7105969 , de um de Fevereiro de mil novecentos e novente e nove, emitido pelo Arquivo de Identificação Civil de Maputo.

NONO

VÂNIA MARGARIDA DE SOUSA LEMOS, casada com Ulisses António Gomez Oviedo, sob o regime de separação de bens, natural de Maputo, de nacionalidade Moçambicana, e residente nesta cidade, portadora do Bilhete de Identidade número $110172415 \mathrm{~T}$, de dois de Novembro de dois mil . emitido pelo Arquivo de Identificação Civil de Maputo.

\section{DÉCIMO}

JORGE MANUEL DE OLIVEIRA DIAS, solteiro, maior, natural de Maputo, de nacionalidade Moçambicana, e residente nesta cidade, portador do Bilhete de Identidade número:110417073F, de dezanove de Março de dois mil e três, emitido pelo Arquivo de Identificação Civil de Maputo.

----Verifiquei a identidade dos outorgantes por exibição dos seus documentos acima mencionados.

\section{-.--E DISSERAM:}

----Que, tendo Ihes sido reconhecida a personalidade jurídica por despacho de vinte e dois de Outubro de dois mil e três, de Sua Excelência o Ministro da Justiça, pela presente escritura pública, constituem entre si, uma Associação denominada "MUVART-MOVIMENTO DE ARTE CONTEMPORÂNEA DE MOÇAMBIQUE", com sede na Cidade de Maputo, que se regerá pelos artigos constantes do documento complementar elaborado nos termos do número dois do artigo Septuagésimo Oitavo do Código do Notariado, que fica a fazer parte integrante desta escritura e que 
os outorgantes declaram ter lido, tendo perfeito conhecimento do seu conteúdo, pelo que é dispensada a sua leitura.

Assim o disseram e outorgaram

Instruem o presente acto os documentos seguintes:

Despacho de sua Excelência, o Ministro da Justiça;

Certidão Negativa do Registo Comercial;

Uma procuração

Lí e expliquei o conteúdo e efeitos legais desta escritura, em voz alta na presença dos outorgantes com advertência especial da obrigatoriedade de ser requerido o registo deste acto na Conservatória competente no prazo de noventa dias contados a partir de hoje após o que vão assinar comigo Notário.

+ Pompilio tilario

- Yarrer Bewl

+ Carne. Mavia Miange.

- chvisia hejansos Tilipe Montate.

x CEleghivi Bento Mondane

* varion Bonifacio Muturewnye

Ofrefem .

- Vania

- juge Manuel de eluvina Dín

Q Notarí

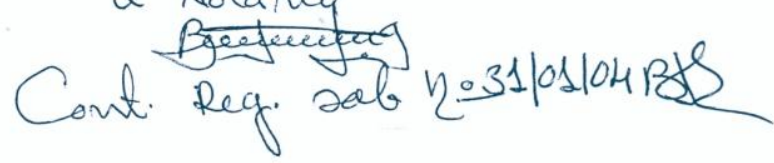


DOCUMENTO COMPLEMENTAR ELABORADO NOS TERMOS DO NÚMERO DOIS, ARTIGO SETENTA E OITO DO CÓDIGO DO NOTARIADO, QUE FICA A FAZERPARTE DA ESCRITURA LAVRADA DE FOLHAS2OA.3.1.FOLHAS........DO LIVRO//8 ADO QUARTO CARTÓRIO NOTARIAL DE MAPUTO.

\section{ESTATUTOS}

\section{CAPITULO I}

Denominação, sede e objectivos

Artigo 1.

(Denominação)

A Associação "Movimento de Arte Contemporâneo", de Moçambique, que usará como abreviatura a sigla MUVART, é uma instituição de carácter cultural, sem fins lucrativos, que desenvolve a sua actividade no quadro dos presentes estatutos e da legislação em vigor na República de Moçambique.

\section{Artigo 2. ${ }^{\circ}$}

(Sede)

A MUVART tem sede em Maputo, na República de Moçambique, podendo ter delegações ou outras formas de representação em outras cidades do país e no estrangeiro.

\section{Artigo $3 .^{\circ}$}

(Objectivos)

A MUVART visa activar e promover a arte contemporânea dentro e fora de Moçambique, através de actividades artísticas do conceito contemporâneo, tais como:

a) Praticar atelieres de pintura, escultura, gráficas, multimédias, vídeo, instalações, performance, land art, etc.

b) Desenvolver actividades de sensibilização, designadamente conferências, debates, workshops, sociologia das artes, critica das artes, etc.;

c) Desenvolver a difusão artística, através de exposições colectivas e individuais, de caracter nacional e internacional;

d) Promover actividades pedagógicas, leccionando aulas de arte para adultos, crianças ou jovens;
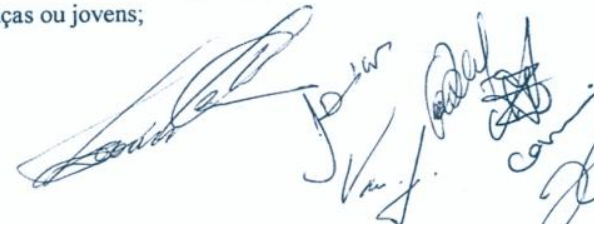
e) Contribuir para o intercâmbio cultural com outros organismos congéneres nacionais e internacionais.

\section{CAPITULO II}

Dos membros

\section{Artigo $4 .^{\circ}$ \\ (Categorias)}

A Associação tem três categorias de membros: Efectivos, Contribuintes e Honorários

a) Podem ser membros Efecctivos todas as pessoas que realizem uma actividade cultural ou alguma tarefa de apoio à mesma, que sejam membros fundadores ou aceites como membros segundo o Regulamento Interno da MUVART, e aceitem os estatutos da mesma;

b) Podem ser membros Contribuintes todas as pessoas individuais ou colectivas que se proponham contribuir para o desenvolvimento da Associação através de uma contribuição material regular, cujos direitos serão regulados pelo regulamento interno da MUVART e aceitem estes estatutos;

c) Podem ser designados membros Honorários, as pessoas individuais ou colectivas, que tenham contribuido de forma relevante para o desenvolvimento da Associação ou para a promoção da arte contemporânea, dentro ou fora de Moçambique.

\section{Artigo 5. \\ (Direitos)}

1. São direitos dos membros efectivos:

a) Participar em todas as actividades da MUVART;

b) Usar as instalações da MUVART dentro dos limites do seu regulamento de uso;

c) Votar e ser eleito para os órgãos da MUVART;

d) Apresentar propostas, sugestões, reclamações, petições, por escrito, à direç̧ão;

e) Solicitar a convocação da Assembleia geral extraordinária;

f) Pedir a alteração dos Estatutos da MUVART;

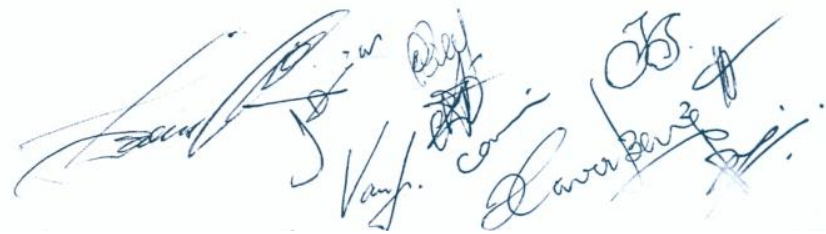


g) Participar na discussão e decisão dos assuntos relacionados com a vida e as actividades da Associação

h) Propor a admissão de novos membros;

i) Desvincular-se da associação.

2. São direitos dos membros contribuintes e honorários:

a) Ser informados regularmente das actividades da MUVART;

b) Usar as instalações da MUVART dentro dos limites do seu regulamento de uso;

c) Apresentar propostas, sugestões, reclamações, petições, por escrito, à direç̧ão.

d) Participar na Assembleia geral, sem direito a voto;

e) Propor a admissão de novos membros;

f) Beneficiar de um desconto de cinquenta por cento no ingresso a cada sessão das diversas actividades da MUVART;

g) Devincular-se da associação.

\section{Artigo $6^{\circ}$}

(Deveres)

São deveres de todo o membro da MUVART:

a) Conhecer, aplicar e cumprir os princípios e disposições constantes no presente Estatuto e no Regulamento Interno da MUVART;

b) Zelar pelo património da MUVART;

c) Exercer com honestidade, zelo, competência e dedicação os cargos para os quais for eleito e por si aceites;

d) Defender o bom nome e prestígio da MUVART.

e) Participar à direç̧ão as insfracções de que tiver conhecimento

f) Pagar pontualmente as quotas às quais estiver vinculado.

\section{Artigo 7.}

(Sanções)

1. No caso de violação das disposições constantes no presente Estatuto e no Regulamento Interno da MUVART serão aplicadas aos membros infractores sanções disciplinares consoante a gravidade de cada caso.

2. As sanções disciplinares serão aplicadas pelo Conselho de Direcção, mediante processo disciplinar previamente instaurado por escrito, em que deverão constar as faltas cometidas, sua prova, as declarações dos membros em causa, devendo a estes ser entregue cópia do processo. 
3. As sanções deverão ser ratificadas ou rectificadas pela primeira Assembleia Geral realizada após aplicação da sanção.

4. São sanções disciplinares:

a) Repreensão;

b) Suspensão dos direitos dos membros por um período de três meses até um ano, de acordo com a gravidade da falta;

b) Exclusão da MUVART.

\section{CAPITULO III \\ DOS ÓRGÃOS}

\section{Artigo 8. ${ }^{\circ}$}

(Órgãos)

São órgãos da MUVART

a) A Assembleia Geral;

b) O Conselho de Direç̧ão;

c) O Conselho Fiscal.

SECÇÃO I

Assembleia Geral

Artigo 9.०

(Constituição)

A Assembleia Geral é constituída por todos os membros da MUVART em pleno gozo dos seus direitos.

Artigo 10.

(Mesa da Assembleia Geral)

1. Os trabalhos da Assembleia geral serão orientados pela mesa da Assembleia geral

2. A mesa da Assembleia Geral é eleita em Assembleia Geral e o seu mandato tem a duração de cinco anos.

3. A mesa da Assembleia geral é constituída por um presidente, um vice-presidente e um secretário.

4. Caso algum dos elementos esteja ausente da sessão, será, nesta, substituído por um dos membros presente, convidado para o efeito.

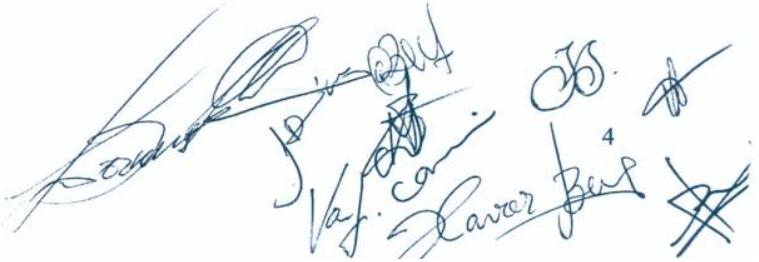




\section{Artigo 11. ${ }^{\circ}$ \\ (Competência da Mesa da Assembleia Geral)}

Compete à mesa da Assembleia geral :

a) Convocar a Assembleia Geral

b) Orientar os trabalhos da Assembleia Geral

c) Elaborar as actas das sessões.

Artigo 12.

(Sessões da Assembleia Geral

1. A Assembleia Geral reunirá em sessão ordinária uma vez por ano e será convocada pela Conselho de Direç̧ão, com uma antecedência mínima de um mês para a apreciação do relatório de actividades as contas do exercício findo e o orçamento para o ano seguinte.

2. A Assembleia Geral extraordinária é convocada pelo Conselho de Direç̧ão ou pela Mesa da Assembleia Geral, com uma antecedência mínima de dez dias, por solicitação por escrito de trinta por cento dos membros efectivos em pleno gozo dos seus direitos. 3.Para que a Assembleia Geral possa iniciar os seus trabalhos, é necessário que estejam presentes pelo menos metade dos seus membros. Caso, à hora marcada na convocatória, tal não se verifique, a Assembleia Geral poderá funcionar meia hora depois, com qualquer número de membros.

4.Exceptua-se a Assembleia Geral extraordinária, em que a sessão só se iniciará se estiverem presentes pelo menos dois terços dos membros solicitantes.

Artigo 13.

(Competências da Assembleia Geral)

Compete à Assembleia Geral:

a) Eleger a Mesa da Assembleia Geral, o Conselho de Direcção e o Conselho Fiscal;

b) Zelar pela rigorosa observância dos presentes Estatutos e demais regulamentos da MUVART;

c) Estabelecer e aprovar o plano geral de actividades para o exercício seguinte;

d) Apreciar e aprovar os relatórios de actividades e as contas referentes ao ano anterior;

e) Discutir as propostas que lhe sejam apresentadas e votá-las

f) Ratificar ou rectificar as sanções impostas aos membros pela direcção;

g) Definir e aprovar os Estatutos e respectivos regulamentos, bem como as respectivas alterações;

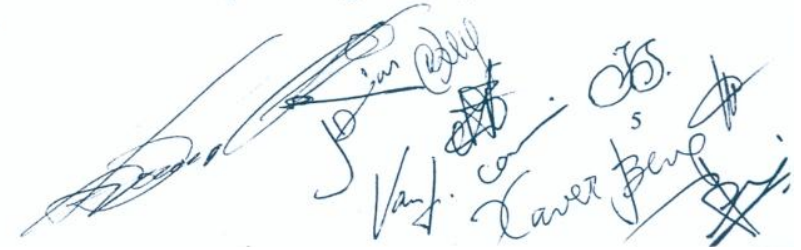


h) Deliberar a extinção da MUVART;

i) Sancionar a admissão de novos membros;

j) Apreciar, discutir, aprovar ou alterar os pareceres do Conselho Fiscal.

\section{Artigo 14. \\ (Deliberações)}

1. A Assembleia Geral delibera por maioria absoluta dos membros presentes.

2. A deliberação sobre a alteração dos estatutos deve ser tomada por maioria de pelo menos três quartos dos membros presentes em Assembleia Geral.

3. A deliberação sobre a dissolução da MUVARTdeve ser tomada por maioria de pelo menos três quartos do número de todos os membros da MUVART.

\section{SECÇÃO II}

\section{Do Conselho de Direcção}

\section{Artigo 15. ${ }^{\circ}$}

(Mandato do Conselho de Direcção)

O Conselho de Direcção é eleito pela Assembleia Geral e o seu mandato tem a duração de cinco anos.

Artigo 16. ${ }^{\circ}$

(Constituição do Conselho de Direcção)

1. O Conselho de Direcção é constituido por cinco membros titulares e dois suplentes.

2. Os cargos do Conselho de Direç̧ão são os seguintes: presidente, vice-presidente e três vogais.

3. Os membros suplentes do Conselho de Direç̧ão substituirão, pela mesma ordem, os membros titulares ausentes ou no impedimento do exercício das suas funções.

\section{Artigo 17.}

(Competências do Conselho de Direcção)

Compete ao Conselho de Direcção:

a) Gerir as actividades e os fundos da MUVART;

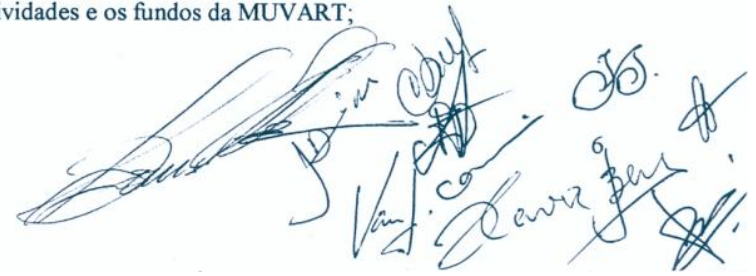


b) Criar, quando considerar necessário, comissões de actividades que ficarão sob sua orientação e autoridade;

c) Convocar a Assembleia Geral ordinária e extraordinária bem como a respectiva ordem de trabalho;

d) Cumprir e fazer cumprir os Estatutos e demais regulamentos da MUVART;

e) Executar as deliberações definidas e aprovadas pela Assembleia Geral;

f) Deliberar sobre as propostas e sugestões, reclamações ou petições que os membros the dirijam por escrito;

g) Designar representantes da MUVART;

h) Admitir membros da MUVART de acordo com o presente Estatuto;

i) Aplicar sanções;

j) Representar a MUVART em juízo e fora dele;

k) Empregar pessoas, alugar ou adquirir bens móveis e imóveis, sempre que considerar necessário para a realização das actividades da MUVART;

1) Praticar os demais actos nos termos da Lei, dos Estatutos e do regulamento interno.

SECÇ̃̃O III

Do Conselho Fiscal

Artigo 18..$^{\circ}$

(Mandato do Conselho Fiscal)

1.0 Conselho Fiscal é o órgão fiscalizador da MUVART.

2. O mandato dos membros do Conselho Fiscal é de cinco anos.

Artigo 19.

(Constituição do Conselho Fiscal)

O Conselho Fiscal é constituido por três membros: um presidente, um vice-presidente e um vogal.

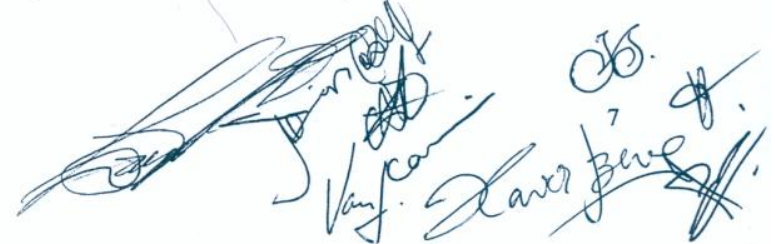


Compete ao Conselho Fiscal:

a) Analisar a situação económica e financeira da MUVART

b) Dar parecer sobre os relatórios de actividades e contas da MUVART elaborados pelo Conselho de Direç̧ão

c) Verificar se os fundos da MUVART estão a ser correctamente aplicados;

d) Apresentar relatórios sobre o seu trabalho, pelo menos nas sessões ordinárias da Assembleia Geral;

e) Zelar, em geral, pelo cumprimento, por parte do Conselho de Direcção, do presente Estatuto, regulamentos, plano e deliberações da Assembleia Geral.

\section{CAPITULO IV}

Dos fundos

Artigo 21..$^{\circ}$

(Proveniência)

Os fundos da MUVART provém

a) Da quotização dos seus membros;

b) Das actividades de carácter permanente ou temporário por ela promovidas;

c) De doações efectuadas por pessoas individuais ou colectivas.

\section{Artigo 22.}

(Gestão)

Os fundos devem ser geridos por forma a reverterem para a mesma Associação.

Artigo 23.

(Casos Omissos)

Em tudo que estiver omisso no presente Estatuto recorre-se a legislação aplicável sobre a matéria.

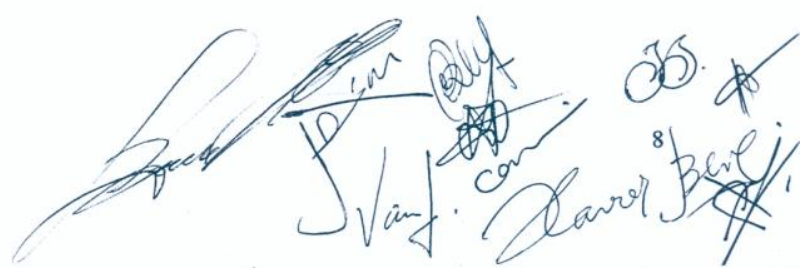




$$
\begin{aligned}
& \text { L } 118-A \\
& \text { th } 20-31
\end{aligned}
$$

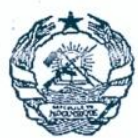

\section{REPÚBLICA DE MOÇAMBIQUE \\ MINISTÉRIO DA JUSTIÇA}

Gabinete do Ministro

\section{DESPACHO}

Um grupo de cidadãos da "ASSOCiAÇão MUVARTE - MOVIMENTO DE ARTE CONTEMPORÂNEA DE MOÇAMBIQUE " requereu ao Ministério da Justiça o seu reconhecimento como pessoa jurídica, juntando ao pedido os estatutos da constituição.

Apreciados os documentos entregues, verifica-se que se trata de uma Associação que prossegue fins lícitos, determinados e legalmente possíveis e que o acto de constituíção e os estatutos da osma cumprem o escopo e os requisitos exigidos por lei nada obstando, o seu reconhecimento.

Nestes termos e no disposto no $\mathrm{n}^{\circ} 1$ do artigo 5 da lei no $8 / 91$, de 18 de Julho, e artigo 1 do Decreto n²1/91, de 3 de Outubro, vai reconhecida como pessoa jurídica a "ASSOCIAÇão MUVARTE MOVIMENTO DE ARTE CONTEMPORÂNEA DE MOÇAMBIQUE".

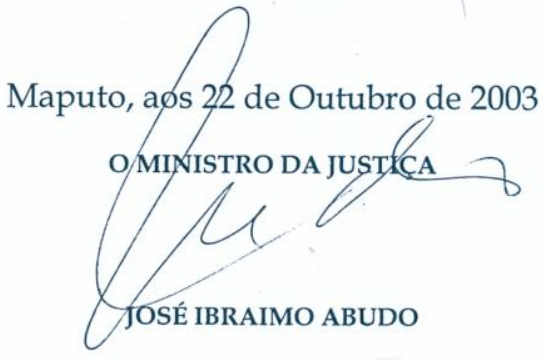




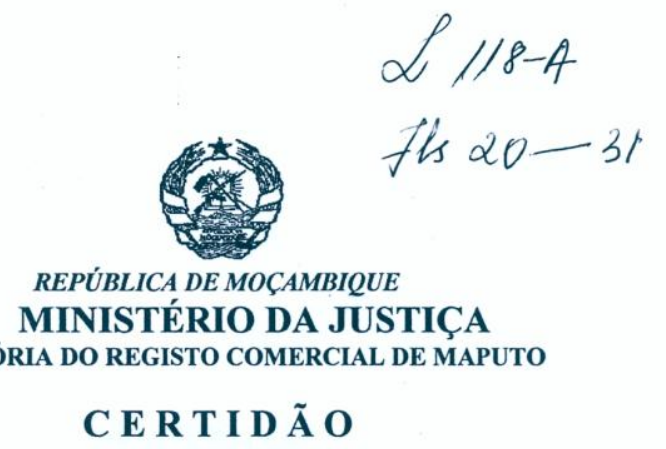

\section{CONSERVATÓRIA DO REGISTO COMERCIAL DE MAPUTO \\ C E R T I D Ã O}

MINISTÉRIO DA JUSTIÇA

---Deferindo ao requerido na petição apresentada no livro Diário sete de Fevereiro de dois mil e três, CERTIFICO que, revendo os livros do Registo Comercial, não se acha matriculada qualquer associação com a denominação de "MUVART - MOVIMENTO DE ARTE CONTEMPORÂNEA DE MOÇAMBIQUE”, nem outra por tal forma semelhante, que possa induzir em erro.

----Por ser verdade, se passou a presente certidão, que depois de revista e consertada, assino.

----Esta certidão tem a validade de noventa dias

----Maputo, sete de Fevereiro de dois mil e três.

O AJUDANTE DO CONSERVADOR,

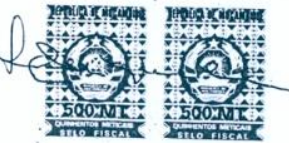




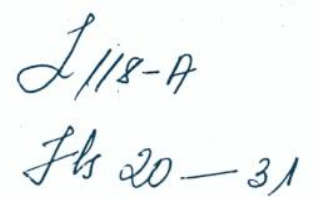

\section{PROCURAÇÃO}

--- No dia três de Dezembro do ano dois mil e três, nesta cidade de Paris e na Embaixada da República de Moçambique, perante mim, Carlos Manuel da Costa, Primeiro Secretário e Responsável da Secção Consular da mesma Embaixada, compareceu como outorgante:- Quentin Dieudonné Patrick Marie Lambert, casado, natural de Hazebrouck, de nacionalidade francesa e residente em Paris, pessoa cuja identidade verifiquei face ao seu passaporte n० 99AE62325, emitido aos seis de Março de dois mil e três, pela Embaixada da França em Maputo.

---E por ele foi dito: Que, pelo presente instrumento, constitui seu bastante procurador, Pompílio Hilário, casado, residente em Maputo, Avenida Zedequias Manganhela $n^{\circ} 5411$, a quem confere poderes necessários para em nome do mandante assinar todos os documentos relativos à Associação Movimeto de Arte Contemporânea em Moçambique. Assim o disse e outorgou. Esta procuração foi lida e explicado o seu conteúdo em voz alta ao mandante, o qual vai assinar comigo, Primeiro Secretário e Responsável da Secção Consular da Embaixada da República de Moçambique em Paris.

Fun Fith

Secção Consular da Embaixada

da República de Moçambique em Paris

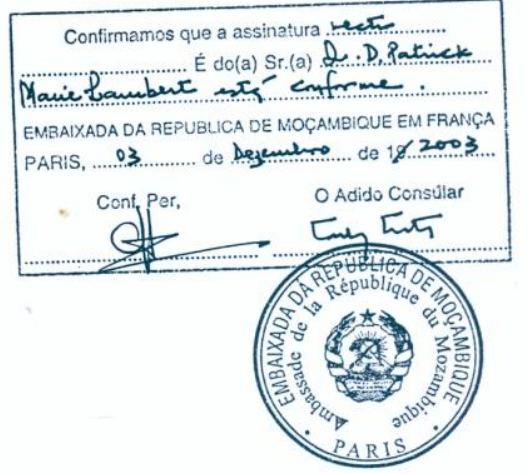





\section{Contexto}

O processo da prática das artes plásticas e visuais é, em nosso entender, um jogo de mudanças e questionamentos constantes de paradigmas. É nele que se constrói a História de Arte. A convivência e a sobrevivência de paradigmas tem caracterizado o último século que conduziu a uma situação de abertura a todos eles e uma enorme diversificação traduzida pela Arte Contemporânea.

O movimento artístico internacional conhecido por "Arte Contemporânea" caracteriza-se por uma linha de esperimentação de novas técnicas, materiais, suportes, e atitudes diversificadas. Fazer Arte Contemporânea é o acto de conceber e materializar uma ideia para interpelar uma situação.

A figura humana já não constitui necessariamente um elemento importante de exploração artística como aconteceu nos últimos séculos, embora a Arte Contemporânea seja essencialmente direccionada para o Homem e os artistas se preocupem e assumam posição crítica face à sociedade. A Arte Contemporânea é uma arte viva, uma arte que engloba numerosas abordagens para além das tradicionais (pintura, escultura, gravura...). Dependendo do género de intervenção, vai tomando designações específicas como por exemplo:

Animação- Módulos de aparência tridimensional produzidos por computador e que podem ser "percorridos" pelo espectador ou vistos através de diversas figuras virtuais que se movem num ecrã.

Apropriation Art- Os objectos ou textos são tirados do seu contexto cultural e colocados sem alteração num novo contexto, onde adquirem outro significado.

Arte Digital- $\quad$ A arte que utiliza os meios oferecidos pela informática como a multimédia, e outros.

Arte Interactiva- Arte que prevê uma intervenção directa do espectador na obra. Frequentemente, esta intervenção torna-se possível através do computador e outros meios.

Arte pública- São intervenções feitas em lugares públicos: (praças, jardins, ruas, etc.) com o fim preciso de expressar e projectar ideias que tenham a ver com o sítio.

Body Art- É a arte que toma o corpo por tema e que faz dele o objecto central da criação e sempre a fotografia e o vídeo como um média.

Instalação- Entendida como obra de arte que integra o espaço de exposição (de que se apropria/altera) como uma componente estética. 

natureza: no campo, na praia, nas montanhas, etc.

Performance- Trabalho artístico apresentado ao público sob a forma de uma acção ou representação (teatral), etc.

De uma forma simplificada, pode dizer-se que a Arte Contemporânea, caracterizase por uma atitude de fugas progressivas ao conceito definido pelas academias tradicionais de arte, mudando muito rapidamente e expressando-se de forma muito diversa.

\section{Justificação do projecto}

Em Moçambique, a Arte Contemporânea também se faz sentir, mesmo que seja de uma forma tímida. A sua expansão exige uma mudança no conjunto de todo o sistema tradicional da vida artística mesmo que este seja pouco desenvolvido como em Moçambique. O público, em geral, tem dificuldades em acompanhar as inovações.

Os mediadores (Ministério da Cultura, Museus de Arte, Galerias, Centros Culturais, Instituições de ensino e outros agentes) são frageis ou mesmo inexistentes e têm, em geral, dificuldades de cumprir as suas missões e integrar as mudanças nalguns avanços que se verificam.

Apesar desta situação, o processo da prática das artes plásticas em Moçambique tem vindo a revelar uma vitalidade e desenvolvimento contínuo, tal como demostraram os resultados da participação moçambicana no último grande evento regional, o festival de artes plásticas da SADC 2000, na Namíbia, onde Moçambique foi considerado um país com uma boa representação, no conjunto dos países participantes, e a participação nas últimas exposições que tiveram lugar no país. Moçambique tem no entanto estado ausente de muitos eventos africanos e internacionais de renome no contexto da Arte Contemporânea.

O desenvolvimento artístico que se verifica localmente revela por um lado a responsabilidade e a capacidade criativa do artista moçambicano face ao seu trabalho e, por outro lado, o apoio que lhe tem sido concedido por parte de alguns mediadores. A vitalidade das artes plásticas moçambicanas, também se revela com o facto de se registar actualmente um número cada vez maior de novos artistas, o que acontece pela primeira vez na curta história das artes plásticas de Moçambique independente. Mas esta vitalidade passa principalmente pela adesão, interesse e motivação por parte do próprio artista, e assenta no seu esforço (quase sempre com meios precários) para se afirmar e sobreviver. A prática das artes plásticas em Moçambique é considerada uma actividade secundária, mesmo quando os factos demostram que neste País está presente uma grande potencialidade artística capaz de competir no panorama internacional. A arte em Moçambique precisa de se afirmar como instrumento fundamental e interviniente na sociedade. As artes plásticas devem ser repensadas e revalorizadas pois há actualmente sobre elas diversos esteriótipos e estigmas. 
É urgente alargar o número de apreciadores interessados pela arte, abrir novos horizontes em relação a novas formas de prática artística e estender este esforço para além da cidade capital. Por estas razões, não admira que as infraestruturas que existem não satisfaçam as exigências necessárias ao desenvolvimento da arte.

Face a estas fragilidades de mediação artística em Moçambique e dado o interesse em incentivar a prática da Arte Contemporânea, um grupo de artístas "contemporâneos" pretende levar a cabo projectos de intervenção no mundo da Arte Contemporânea em Moçambique e no exterior.

O Movimento de Arte Contemporânea, ambiciona ser um meio activo de promoção da estética conhecida universalmente por "Arte Contemporânea". Pretende favorecer o seu desenvolvimento realizando acções de intervenção prática e de reflexão sobre ela.

\section{A função do movimento}

Incentivar a prática da Arte contemporânea, difundi-la em Moçambique e no exterior. Criar uma ponte de convívio deste estilo de prática artística, com outros do género nos paises da região e a nível internacional. Com este movimento pretende-se contribuir para a diversidade da prática artística em Moçambique.

Através de acções de sensibilização dirigidas ao público pretende-se contribuir para o entendimento da linguagem do artista e para reduzir lacunas de sensibilidade artística, causadas por falta de educação artística e de exposição a práticas artísticas deste tipo.

\section{Objectivos}

Desenvolver actividades de carácter artístico no âmbito da estética "Contemporânea" como um testemunho do mundo de hoje, fazendo de Moçambique, um centro de criação artstica que compete no panorama internacional.

Incentivar e promover a participação dos artistas e dos criadores artísticos moçambicanos, na arena internacional, não como espelhos de uma África congelada dentro das suas tradições mas como testemunhos do mundo de hoje, a partir de riquezas humanas, singulares e contemporâneas.

Criar um movimento com capacidade crítica e de reflexão sobre os problemas sócio-culturais de Moçambique e que tenha um papel significativo na formação ideológica e cultural da sociedade.

\section{Beneficiários}

O projecto dirige-se a todos os artistas e, de uma forma particular, aos artistas que partilham a estética da Arte Contemporânea. Vai beneficiar também todo o público amante das artes e todos os agentes participantes no sistema da arte contemporânea. 
O movimento inicia com 11 artistas (vide pág. 6) todos vivendo em Moçambique, com cursos ou experiências suficientes no mundo da Arte contemporânea. As suas experiências técnicas e influências estéticas adquiridas em Moçambique e noutros países tais como: África do Sul, Brasil, Cuba, Canadá, França, Namíbia, Portugal, Ucrânia, etc.

serão exploradas em benefício da vida do movimento, quer com artistas membros ou convidados de Moçambique quer com artistas e personalidades relevantes de outros países.

movimento adopta uma estratégia de abertura a outros praticantes, amantes e agentes de arte (Artistas, Críticos de Arte, Historiadores de Arte, Arquitectos, Sociólogos de Arte, Gestores Culturais e outras entidades) para permitir uma animação progressiva e equilibrada, construindo assim o seu público. Nesta estratégia o movimento pretende ter uma atitude curiosa, atenta e exigente, promovendo acções de sensibilisação em torno da Arte Contemporânea.

\section{Actividades}

As actividades do movimento subdividem-se em duas vocações de acção: teórica e prática.

A vocação teórica - É a vocação responsável pela sensibilização do público e do artísta, por meio de uma reflexão crítica sobre diversos problemas sociais, culturais e artisticos, em debates, conferências, pesquisas, publicações, etc.

A vocação prática - Esta vocação deve garantir eventos artísticos, priorizando as tendências contemporâneas, tais como: Instalação, Land art, Performance, Arte pública, Body Art, etc. para permitir um campo de pesquisa e de autoavaliação. Importa deixar claro que a prática das artes convencionais tais como: a Pintura, o Desenho, a Escultura, a Gravura entre outras, embora não constituindo uma prioridade de promoção e difusão na política do movimento da Arte Contemporânea, encontram-se integradas desde que obedeçam a uma estratégia pertinente e critica.

\section{Sustentação}

As acções artísticas do Movimento não constituem, em geral, actividades de lucro, são acções de mera apreciação cultural. Os artistas que integram o movimento pagam uma quota mensal e angariam fundos, através de vários meios, em cada uma das suas actividades. $O$ movimento colabora com parceiros e instituições relevantes para a sua actividade e procura potenciais mecenas e financiadores capazes de colaborar na promoção e desenvolvimento da Arte Contemporânea.

\section{Duração}

Permanente 


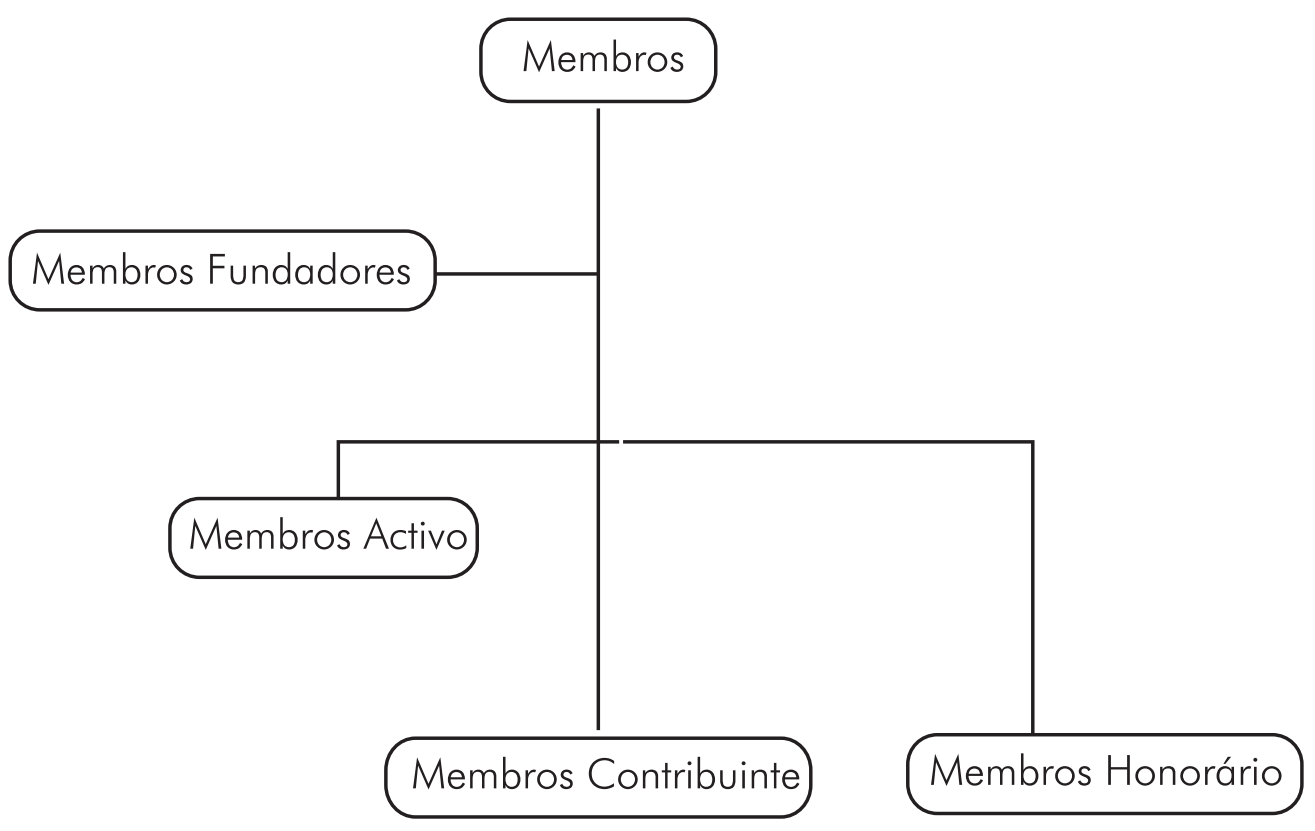

\section{OS MEMBROS FUNDADORES}

São membros fundadores desta associação, artistas plásticos, nomeadamente: Anésia Manjate, Carmen Muianga, Celestino Mondlane, Xikhossa, Gemuce, Ivan Serra, Jorge Dias, Marcos Bonifácio, Quentin Lambert, Vânia Lemos e Xavier Mbeve.

Todos os membros fundadores possuem formação ou experiências suficientes no campo das artes, sendo a maioria artistas ou profissionais de Artes Visuais em diversas áreas.

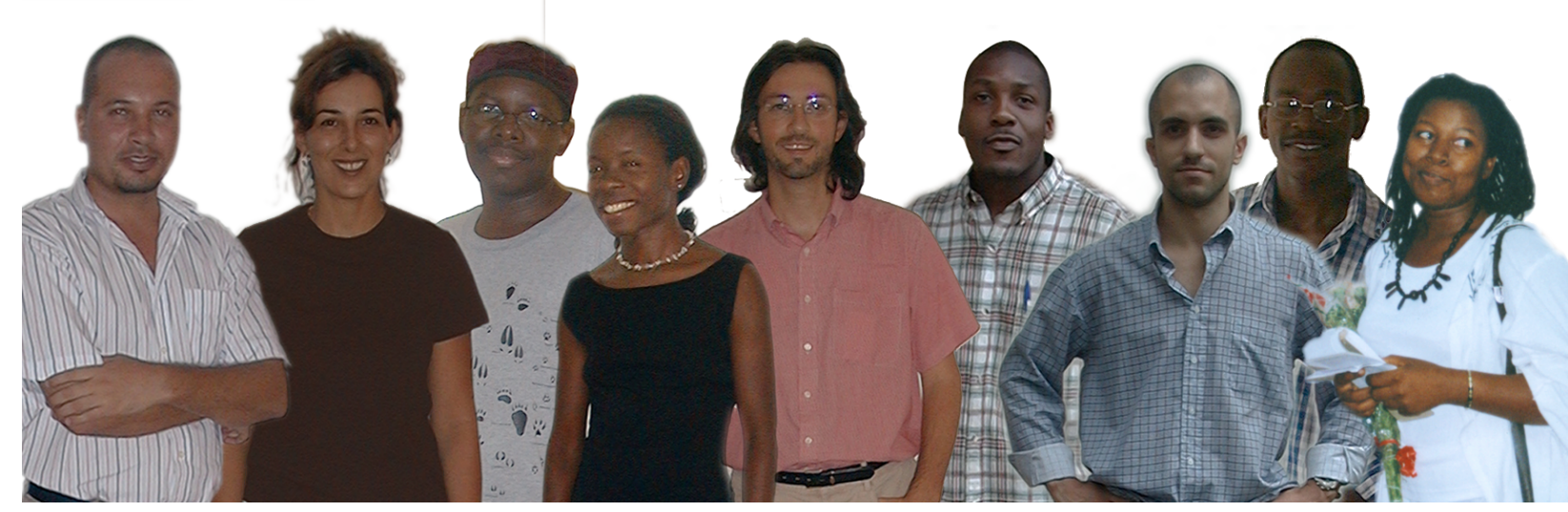

Cont a c tos:

$082301217 / 082704620$ - Gemuce

082838405 - Marcos Bonifácio

082865656 - Jorge Dias 


\section{ANEXO C}

\section{ENTREVISTA COM FILIMONE MEIGOS}

Sábado, 21 Maio 2011 00:00 Policarpo Mapengo, acessado em http://www.opais.co.mz/index.php/entrevistas/76-entrevistas/14217-o-resgate-de-outrossaberes.html, dia 22/05/2011

O resgate de outros saberes

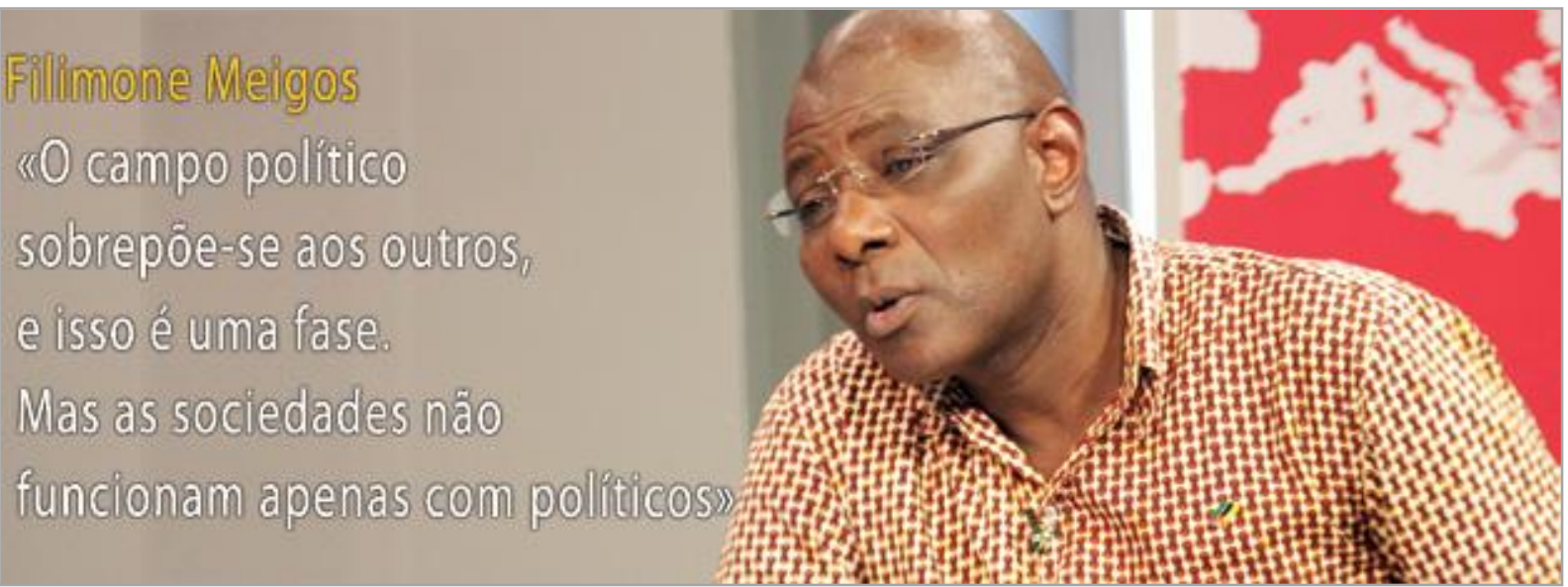

“Corpus Quantum” para nos ajudar a compreender a dinâmica que a sociedade deve ter

Com Filimone Meigos pode fazer-se uma caminhada pelo tempo como se nós o dominássemos por completo. Ele fala de "Corpus Quantum" para nos ajudar a compreender a dinâmica que a sociedade deve ter. Falámos do papel da sociologia, da literatura e da política. Mas voltámos sempre à cultura. Voltámos à arte. Resgatámos outros saberes. É assim esta entrevista!

Na noite de abraços reinventava a disposição como recria os seus versos. Em "Poema \& Kalash in Love", nessa sua fuga da guerra para inventar uma "arma de amor", Filimone Meigos mostra a reinvenção da vida. Ele sempre detestou a guerra e inventou "loucuras" para fugir dela, como o disse um dos seus companheiros na noite de abraços. Já o tinha assumido antes em "Kalash in Love" - "A arma arma-me com tristeza de a dever acariciar/mas faço-o por sufrágio universal" - e o confirmaria nesta entrevista feita também para a Stv: "vamos parar de falar de guerra". Parámos!

Mas não parámos de fazer uma incursão pela arte e espreitar a sociologia, que é a sua formação, e a cultura, que - isto é nosso atrevimento - é sua forma de vida. Escreveram em algumas páginas que ele e a sua turma de "Charrua" refizeram a literatura moçambicana. Ele prefere falar de um trabalho que seria uma espécie de - "camaradamente" falando - "mudança na continuidade".

A literatura vinha de uma linha nacionalista e profética de Craveirinha, que sonhava com uma nação com "campeão olímpico", passando por Noémia de Sousa nesse desejo "let my people go". Foi essa poesia que procuraria coabitar com versos de combate de Marcelino dos Santos, que repetia "sim mamã/é preciso plantar/pelos caminhos da liberdade/a nova árvore/da Independência Nacional".

Filimone Meigos faria parte da desconstrução, em termos físicos e temáticos, dos seus versos, assim como o lirismo de Eduardo White, e uma construção "ocupacionista" de Ngungunhane feita por Ungulani. 
Com Meigos, pode fazer-se essa incursão pela literatura, como também pela construção da arte e cultura como um todo. Foi isso que fizemos ao iniciar a conversa pelos muros do Instituto Superior de Artes e Cultura.

Qual é o desafio para o Instituto Superior de Artes e Cultura (ISArC) num país em que as pessoas ainda acreditam mais em cursos tradicionais, como Economia, Direito, Agronomia e Medicina?

Os desafios impostos ao ISArC são os mesmos que são colocados a qualquer uma outra universidade, ou a qualquer outro curso, embora com especificidade. e, na minha opinião, posso referir-me a três ou quatro aspectos muito importantes. Primeiro, a infraestruturação das universidades - quer dizer que as universidades devem estar capacitadas do ponto de vista de laboratórios, auditórios, salas de aulas, telas (para o caso específico das artes), por outro lado, a democraticidade. Quando me refiro à democraticidade, refiro-me não só à eleição, ao funcionamento dos órgãos directivos, mas, acima de tudo, ter o estudante como núcleo central da universidade. Quer dizer, toda a acção de uma universidade deve estar centrada no estudante. Mostrar a pertinência de que as artes e cultura são importantes como economia, agricultura, gastronomia, astronomia, porque as artes e cultura foram sempre consideradas uma área que qualquer um pode fazer sem que tenha saído da escola, por isso que sempre é um equívoco.

Como vamos explicar a uma sociedade acostumada a economistas, juristas e agrónomos que as artes e cultura são importantes para o país?

Há aquela máxima da mãe do Mondlane de que temos que aprender do feitiço do branco. Agora, essa máxima não é apenas um apanágio da agricultura, agronomia, direito ou medicina. Nós temos que saber fazer em todas as áreas, incluindo as artes e cultura. Ora, na minha opinião, a universidade dá a possibilidade para que esse saber fazer seja sistematizado. Nós temos uma situação de agentes culturais que nem sequer sabem explicar o que fazem. são bons artistas, bons escultores, pintores e bailarinos, mas não sabem que tudo o que fazem é sistematizado por via da escola. Por outro lado, ao sermos formados, temos o poder de falar com propriedade e de igual modo a nível nacional e internacional, porque a universidade nos dá conteúdo, técnicas e teorias para podermos falar do que nós sabemos fazer de igual para igual. Isso também é preciso nas áreas das artes e cultura, e foi exactamente por isso que foi criado o ISArC.

Mas quem tem acesso ao ISArC. Como é feita a selecção de candidatos?

Há um acesso que é feito à luz do ensino superior (12 $2^{\mathrm{a}}$ classe) e exames de admissão. Para o curso de designer, o candidato tem que apresentar um portfólio (aquilo que já fez) e há uma entrevista. É verdade que assinámos convénios com algumas instituições, à luz das quais há candidatos que têm entrada directa e bolsas. Julgamos nós que favorece alguns sectores que ao longo dos anos foram desfavorecidos, e nós pensamos que, ao fazer este tipo de equilíbrio, estamos a fazer justiça àquilo que, na nossa opinião, foi injustiçado ao longo dos tempos.

$\mathrm{Na}$ questão da justiça, vamos levantar também o que se vem discutindo. Como é que os grandes artistas que não têm formação, casos de Venâncio Mbande, Eduardo Durão, podem dar um contributo. $E$ ao dar um contributo como professores, não haverá um choque entre a ciência e o saber que eles foram adquirindo ao longo do tempo? Como é que esse saber pode contribuir para o ISArC?

No ISArC damos um estatuto especial como professores a Venâncio Mbande, Eduardo Durão, entre outros. Está acolhida essa condição como professores. Infelizmente, a nossa lei do ensino superior não nos permite a entrada directa como estudantes sem que tenham a $12^{\underline{a}}$ classe. Esta é uma guerra que penso que deve ser de todas as universidades, porque há pessoas que têm outros saberes. $O$ que a universidade tem, afinal? É apenas um saber científico. Há outros tipos de saberes de que a universidade precisa. Estou de acordo contigo quando diz que deixar estas pessoas de fora é 
injustiça. Vamos discutir de que forma como pessoas como Venâncio Mbande, Durão e outros, não Ihes sejam apenas outorgados títulos honoríficos, mas também licenciaturas e doutoramentos a partir do saber que acumularam. Na verdade, os saberes são acumulados. O que a universidade faz é outorgar um diploma a partir de conhecimentos acumulados. Como universidade, temos que resgatar outros saberes, acoplá-los à universidade e outorgar não só títulos honoríficos, mas também diplomas.

Que contributo em termos de desenvolvimento económico os jovens saídos do ISArC poderão dar para o crescimento económico de que o país necessita?

Se nós olharmos para os campos sociais, vamos ver que temos economia, cultura, política e por ai em diante. Um jovem formado no ISArC vai poder contribuir na sua própria área de formação. Segundo, vai contribuir, na medida em que vai começar a entender que ao se inserir no processo de desenvolvimento de Moçambique, tem uma mais-valia a dar a partir dos saberes que ele começa a adquirir no ISArC. Entender que aos nossos formandos vai ser injectado um pouco de trabalho, e no processo de desenvolvimento de Moçambique, uma série de saberes e perícias que lhes permitem, eles próprios, contribuir de forma mais sistematizada no processo de desenvolvimento do país. A nossa vocação é formar quadros de nível superior para serem injectados no processo de desenvolvimento do país. Do ponto de vista das indústrias criativas e culturais, formamos uma pessoa de excelência que seja capaz de entender toda esta cadeia de produção artístico-cultural, contribuindo de forma positiva. Como é sabido, as indústrias culturais injectam muito dinheiro nas economias nacionais.

$\mathrm{E}$, no nosso caso, como é que a nossa indústria cultural pode dar um contributo valioso e qualitativo no desenvolvimento do país? Queria que fizesse um olhar como sociólogo e, segundo, como formador de agentes ligados à indústria cultural.

Penso que se formarmos um bom executor, um bom administrador, um bom gestor cultural, um bom pintor, estamos a contribuir de duas maneiras. Primeiro, do ponto de vista epistemológico, esse pintor, gestor, está a trazer algo novo do ponto de vista de visão nas artes e cultura. Segundo, como é que esse formando foi bem formado? Ele vai executar bem a sua tarefa? E ao executar a sua tarefa, ele está cônscio de que está a contribuir sobremaneira na cadeia de valores. Isto é muito importante, porque o processo produtivo comporta o mercado, a componente cultural e processos políticos, porque mexe com aqueles que fazem políticas. e ao fazerem políticas, essas políticas têm que ser adequadas àquilo que nós pensamos que as nossas artes e cultura devem ser.

Parece haver um distanciamento entre a política e as artes e cultura no nosso país, sendo o ISArC e a ECA exemplos que parecem excepções. Como podemos interligar essas duas componentes?

Nós temos um processo histórico bastante curto. São 35 anos de independência. Costumo dividir esse período em duas fases. A que inicia em 1975, até 1986, em que o Estado era promotor e provedor de serviços e bens culturais. De 1986 para cá, com a contribuição do PRE, onde há economia do mercado, a cultura foi sempre passada para o segundo plano. De qualquer maneira, isso não significa que não haja uma vontade política. Aliás, a própria criação do ISArC já demonstra que há vontade política para entender a arte como uma esfera tão importantes quanto as outras. Também é verdade que se tivermos que escolher entre financiar um regadio e um ISArC, certamente que o financiamento irá para o regadio. Aqui, a discussão tem que ser nos seguintes termos: o regadio vai resolver problemas de pão físico, o ISArC vai resolver problemas de pão espiritual. O pão espiritual e o físico valem a mesma coisa, e temos que pensar nisto em termos de perspectivas. O que significa colocarmos para o segundo plano as artes e cultura daqui a 10, 20, 30 anos? Ao mesmo tempo, o que significa não fazer regadios, escolas, no mesmo período? Portanto, temos que ver isto numa perspectiva estratégica. Não há nada que tem que ficar atrás, porque o pão espiritual e o físico valem a mesma coisa. 
Queria que olhasse para o valor político. Estamos a falar de Estados como o nosso, que correm muito para a questão do valor do voto. O pão espiritual de que fala tem tanto valor assim quanto o físico?

Tem muito valor. Repare para as eleições como fenómeno político ou cultural, para todas as realizações políticas e de Estado, inclusivamente. Nenhum evento de Estado ou eleições que se prezem ignoram o trabalho de um pintor, de um designer gráfico, de um músico. A questão que se coloca é: estes criadores não devem ser utilizados apenas para questões programáticas ou questões eleitoralistas. Tem que haver uma política que faça deles membros de uma sociedade; agentes artístico-culturais são tão valiosos quanto um polícia, um agrónomo, etc. É essa questão que coloco e que depende da pertinência de nós conseguirmos demonstrar a partir dos nossos primeiros graduados.

Rebusquemos a sociologia. Em Moçambique, olha-se para este ramo como algo muito novo. Até que ponto a arte e cultura estão dentro da sociologia?

Todos nós somos sociólogos. A única diferença entre os sociólogos da universidade e os da sociedade é que os da universidade têm métodos próprios. O que o sociólogo faz é problematizar e equacionar. É verdade que existem várias áreas dentro dela, como a sociologia política, da cultura, do ambiente. a da arte ainda é nova, mas há muitos trabalhos feitos na área das artes e cultura. Naturalmente que há mais propensão a pensar na área da sociologia do desenvolvimento, da política, etc. Se calhar, devíamos colocar assim a pergunta: porque é que as artes e cultura são relegadas ao terceiro plano? Logo responderia: é por causa da maneira como a concebemos, e esquecemos que as artes exercem um papel muito importante. Aliás, a partir das artes e cultura podemos ler o social. Basta ler o poema "Futuro cidadão", de José Craveirinha, e percebemos que estava lá o que queríamos, como, por exemplo, um campeão olímpico, que queríamos ter uma pátria. $\mathrm{E}$ isto foi escrito nos anos 50, 60. Podemos ainda olhar para bandas como Ghorwane, quando foram denominados "bons rapazes". Com aquele conjunto de canções, podemos aprender o que é que se está a passar em Moçambique, e esse é que é o trabalho do artista, por um lado. Por outro lado, é o trabalho que os sociólogos fazem para, através desses corpos, esses artefactos, podermos explicar o que se passa aqui em Moçambique e em qualquer outra parte do mundo. Se, por lado, as artes e cultura estruturam o sociólogo, por outro, a partir da estruturação, podemos problematizar, equacionar a sociedade e dizer que é isto ou aquilo que o escultor, o poeta e o músico dizem e quem de direito deve tomar em conta.

Recordo-me, agora, que Filimone também já foi actor. Os artistas vão reclamando o seu reconhecimento, primeiro, como profissionais, e também como pessoas que dão um contributo económico e social para este país. Como é que se pode fazer essa construção em termos políticos?

Em primeiro lugar, os artistas devem ajudar-se. O que o Estado faz é ser equitativo, não pode olhar apenas para os artistas, para os desmobilizados de guerra. O Estado tem que olhar para a sociedade como um sistema universal, onde as políticas vão sendo feitas com a necessidade de serem equitativas. Agora, os artistas devem fazer por eles próprios, e eu falo como artista. Temos que estar mais organizados, temos que reivindicar os nossos direitos e, paralelamente, temos que cumprir com os nossos deveres, que cada uma das nossas modalidades seja efectivada efectivamente. Sou Wazimbo, tenho que cantar bem. Sou Ídasse Tembe, tenho que pintar bem, enfim, tenho que fazer bem a minha tarefa e, depois, posso exigir que o Estado reduza os impostos nas tintas, que regule os espectáculos, que regule a Lei de mecenato e todas essas coisas que existem e são benévolas para as artes e cultura. Deve partir do próprio artista, para depois exigir ao Estado, tal como o agrónomo, o economista, os médicos têm "ordem". quero dizer que aquela associação dos músicos deve funcionar; dos escritores deve funcionar. A partir dos grupos de pertença podemos indagar ao Estado para que leve a cabo aquilo que nós pensámos que são os nossos desígnios. 
Está a falar de unidade entre os artistas. O que é que esses artistas podem fazer para além dessa unidade. Estamos a falar de artistas que gostam de reclamar?

Estou a dizer que em todos os segmentos sociais há coisas boas e coisas más. Podes apanhar um bom economista e maus jornalistas, bons agrónomos e maus artistas. Estou a dizer que os maus artistas devem querer ser bons artistas, os maus agrónomos bons agrónomos. Ao seres um bom artista, estás a contribuir, primeiro, para ti. afinal, o que é arte? é a satisfação individual. Arte é criar algo sublime, é o nível mais alto de criação. Quando crias, estás a fazer algo para ti e, depois, para os outros. logo, ao fazeres isso, te outorgas o direito de exigir se fizeres bem aquilo que é a tua missão. O que é uma missão, é ser poeta? E se for, a minha missão é escrever poesia. A partir daí podemos passar para o segundo patamar e dizer: minhas senhoras e meus senhores, eu sou poeta, eu escrevo livros e quero que o meu livro seja posto lá fora e que o Estado subvencione a exportação do meu livro, e por aí em diante.

Como é que um poeta, um sociólogo, olha para a formação superior que existe no país? Estamos a formar gente que vai dar algum contributo, sobretudo quando se fala de democratização do ensino superior?

O poeta olha para esse desafio como a realização de um sonho. O sociólogo olha para essa formação como uma tarefa. Na verdade, seria bom e óptimo que todos nós fôssemos formados, mas, se olharmos para sociedades como a cubana, em que o Estado imprimiu toda uma dinâmica e mais de 90 por cento teve acesso à formação, isso quer dizer que essa sociedade, diga o que disserem, é melhor. E está bem, porque a formação nos dá luzes e abre-nos portas para lidarmos com a realidade circundante. Eu não gosto muito de olhar para os números, embora as estatísticas sejam boas, e eu até tenho uma relação de amor e ódio com ela. O ponto é que sejamos efectivamente bem formados. Até podem ser 500 pessoas, mas estas devem ser capazes de ter o perfil de corresponder aos objectivos que nos impusemos ao formar essa gente, e paulatinamente temos que ser capazes de essa gente que queremos formar ser efectivamente formada. Também não podemos formar só por formar. Também é verdade que, do ponto de vista da Filosofia, temos que ter quantidade para ter qualidade. Qualidade é: se eu formar um gestor cultural, ele deve ser capaz de corresponder ao perfil que me propus a que ele fosse formado. Tem que ser capaz de levar a cabo um projecto, orçamentar, promover um evento e gerir toda a cadeia desse evento, depois equacionar a fase e, inclusivamente, estrategizar futuras acções. É essa gente que nós queremos; um formado capaz de resolver os problemas.

Uma das questões que vêm sendo levantada é a aposta que se faz no ensino superior, e esquece-se do básico. Não estaremos a começar do fim?

Podes ter razão. A única área ou modalidade que tem essa formação total, desde a base até à secundária, é a das artes plásticas. Temos problemas com a dança, música e com as outras áreas. Mas podes questionar por que as artes plásticas, que começaram na mesma altura que as outras áreas, têm escolas e outras não as tem? Bom essa é uma questão que eu próprio deixo no ar, e temos que dobrar o passo para chegarmos aqui. Eu penso que já vimos qual é a equação, qual é problema. Infelizmente, estamos a duplicar tarefas, porque as pessoas têm que ir para a escola normal básica para fazer a $12^{\mathrm{a}}$ classe, ao mesmo tempo ir à escola de música. Em toda a parte do mundo não se faz isso assim, faz-se as duas coisas ao mesmo tempo, até porque se poupa tempo e se cumpre com as funções.

Alguns sites colocam-no como um grande amigo de Eduardo White, com o qual teria mudado o rumo da literatura, com uma poesia com propostas novas e engajadas...

Nós tivemos sorte. Somos de uma geração pós independência e que, por causa daquele contexto, ficámos muito interligados - eu, Suleiman Cassamo, Eduardo White, Armando Artur, Marcelo 
Panguana, Ungulani Ba Ka Khosa e outros. Estas coisas de igualdade de circunstâncias têm que ver com o tempo. Fizemos aquilo que nos competia fazer, que era, por um lado, dar continuidade àquilo que tinha sido feito pela geração de craveirinha, Rui Nogar, Calane da Silva, etc. Mas, por outro lado, fazer uma ruptura do ponto de vista da temática, da estrutura, da forma da poesia que nós começávamos a fazer. Porque White começou a fazer lirismo, uma coisa que era impensável na altura, e eu comecei a desconstruir a forma e os conteúdos, comecei a meter guerra. eu fui oficial do exército, isso tem um pouco que ver, porque é minha história de vida. Mas cada um de nós tem o seu percurso, e juntámos todos estes percursos de uma geração. Eu acho que foi uma boa experiência.

A "Charua" começa a surgir no período pós-independência, quando há um peso da poesia de combate. Há da vossa parte um esforço de ruptura com esse tempo, mas também uma ligação com o que se fazia antes da independência...

Temos uma perspectiva de ruptura e uma perspectiva de continuidade, porquê? Porque estamos na confluência entre o sonho e o ruir desse sonho; estamos na confluência entre utopia e uma distopia; estamos a falar da independência que foi recebida com toda a euforia, mas, ao mesmo tempo, essa independência trouxe outras coisas, porque não foi efectivamente independência.

Quando olha para "Kalash in Love", o que pensa exactamente, muito tempo depois do seu lançamento (1994)?

Eu olho para "Kalash in Love" como fotografia de uma época. Aquele livro começou a ser escrito em Nampula, quando eu estava na escola militar, e fiquei por lá a dar aulas. Quando começou a guerra, tive de ir para a guerra, e, ao voltar, conheci Esménia Sacramento, que tinha um programa de rádio, e nessa altura recomecei a escrever. Tudo isso retorna quando conheço a Esménia, e foi ai que compilei o poema "Kalash in Love". "Kalash in Love" é uma tentativa de dizer que podemos usar a arma para fazer amor, e em si demonstra atrevimento, é uma situação.

Vamos voltar para o período pós-colonial. como é que a nossa sociedade vai evoluindo, desde esse período até agora?

Eu uso isso na minha tese e estabeleço duas épocas. há uma época (75/86) de provedor de bens e serviços culturais, com toda a sua pujança, e que Samora chama de "o tempo da cultura - sol que nunca desce". Muito interessante, porque significa que é uma coisa que está lá em cima, a qual todos temos acesso, que se quisermos se sobrepõe ao económico. De 86 para cá, é exactamente o contrário, o económico se sobrepõe ao político-ideológico, e aí está a teoria que na minha opinião define a artes e cultura de Moçambique.

Aqui, parece trazer o poder que a política vai exercer sobre as outras áreas. Qual é a resposta que as artes e cultura podem dar? Acima de tudo, como é que os nossos intelectuais podem aparecer a dar uma resposta a isso?

Há dois aspectos. Um aspecto é apanágio das sociedades africanas que emergem de lutas de libertação nacional. O campo político sobrepõe-se aos outros, e isso é uma fase. mas as sociedades não funcionam apenas com políticos. As sociedades são vários campos, são vários sistemas, e é isso que aprendi em sociologia. As sociedades são sistemas, mas mesmo que nós pensemos nisso como uma fase, há outros sistemas e outros campos que têm que aparecer como equivalentes à política. e se nós quisermos aprofundar, diríamos que aquilo que se estrutura, aquilo que resta depois de tudo é a cultura, e a cultura estruturante é interdisciplinar, diz respeito a todos os campos. nós temos que começar a olhar para a sociedade como sistemas de campos, no geral, e o campo político também é um campo e não deve sobrepor-se aos outros campos. Dentro desse mesmo campo, também há conflitos de interesses, conflitos de comparação, e é bom que potenciemos as relações de 
comparação, mas também é bom que saibamos que para as sociedades estarem equilibradas, elas estão em conflito.

Qual é a resposta que os académicos podem dar nessa luta e contribuir para que haja um equilíbrio, numa altura em que se fala que nos estados africanos o que mais sobressai é o campo político?

O campo académico é reservatório para a política. ainda bem que é assim. o que se faz normalmente é que aqueles que produzem o saber sejam coaptados para a política e que façam política, porque nós somos animais políticos, quem o disse foi Platão. Se o campo político se socorrer dos académicos, na minha opinião, isso é óptimo, o que não quer dizer que os académicos devem ficar à espera, como se fossem reservatórios no sentido pejorativo do termo. os académicos devem contribuir para o desenvolvimento do país. 


\section{ANEXO D}

\section{PRINCIPAIS CENTROS DE CIRCULAÇÃO E DIVULGAÇÃO DA ARTE}

Os principais centros de circulação e divulgação da arte no espaço moçambicano têm como missão criar condições para os artistas exporem seus trabalhos e/ou criar atividades relacionadas à cena artística. Muitos desses espaços já constituem uma história e podem ser considerados patrimônios nacionais.

Nesta seção iremos pontuar as principais instituições culturais de Maputo, a saber: O Museu Nacional de Arte - MUSART, o Centro Cultural Brasil-Moçambique, Estação Central dos Caminhos de Ferro - CFM, o Instituto Camões - Centro Cultural Português em Maputo, o Centro Cultural Franco-Moçambicano- CCFM, Galeria da Casa de Cultura do Alto Maé, o Centro de Formação Fotográfica - CFF, a Associação Moçambicana- AMF, o Núcleo de Arte da Escola Nacional de Artes Visuais- ENAV e o recente Instituto de Artes -ISArC.

Como já foi dito, a produção artística moçambicana não pode ser entendida como única, pois é variada e distinta, dependendo da sua localização territorial e dos diferentes grupos que a compõem, como exemplificado no segundo capitulo. Esta realidade é explicitada em CARVALHO:

Em África quase todos os países são heterogêneos, visto que incluem dois ou mais grupos étnicos.

Como resultado, existem muitos países divididos em que as diferenças e os conflitos entre estes grupos desempenham um papel importante na política do país. A profundidade desta divisão varia, normalmente, ao longo do tempo. Divisões profundas, no interior de um país, podem levar à violência generalizada ou ameaçar a sua própria existência. É mais provável que esta última ameaça ocorra, induzindo movimentos para a autonomia ou a separação, quando as diferenças culturais coincidem com diferenças de localização geográfica. ${ }^{177}$

Para expressar esta variedade da produção surge a necessidade do debate sobre o seu destino, com destaque para as coleções, e consequentemente em seu registro e salvaguarda. O papel destas instituições moçambicanas tem sido este desde a criação dos seus museus ${ }^{178}$ e, no caso específico, do Museu Nacional de Arte, MUSART.

177 CARVALHO, Rui Moreira. Compreender África, teoria e práticas de gestão. Rio de Janeiro:Editora:FGV, 2005, p.75.

178 O International Council of Museums (ICOM, 2001) define o Museu: uma instituição permanente, 
Inicialmente, os espaços de divulgação da produção artística dão-se nos museus e nas galerias, instituições públicas e/ou privadas. Em Moçambique estes espaços são poucos e significativos e, entre os PALOPS ${ }^{179}$, é um dos países que contam com esta estrutura.

No seu contexto original, SUANO observa; "A formação de coleções de objetos é provavelmente quase tão antiga quanto o homem e, contudo, sempre guardou significados diversos, dependendo do contexto em que se inseria." 180

Ou seja, é necessário remontar às origens da palavra e do sentido do museu em si, para cautelosamente analisar o que são os espaços expositivos hoje e como os artistas estão inserindo suas propostas artísticas nesses mesmos locais.

Para REBOLLO, outra questão se faz presente:

É necessário que os objetos mostrados sejam reconhecidos como representantes de um mundo dotado de sentido para o público, com um fundamento social. Dessa forma, a exposição tem a função de mostrar objetos em torno dos quais há um consenso quanto a seu estatuto de patrimônio cultural; ela não somente se torna visível mas dá visibilidade ao sujeito que com ela interage ${ }^{181}$

Tanto SUANO quanto REBOLLO chamam a atenção para a constituição de processo museulógico atrelado às necessidades da sociedade. Com base no percurso artístico do grupo de artistas estudados, os integrantes do Movimento de Arte Contemporânea de Moçambique, MUVART, segue-se um roteiro detectado no curriculum desses artistas.

Com essas exposições, o artista moçambicano pode divulgar seu trabalho e trazer ao público experiências estéticas e artísticas; transitando entre as mais diversificadas linguagens o cidadão mergulha no mundo da arte.

sem fins lucrativos, a serviço da sociedade e do seu desenvolvimento, aberta ao público e que adquire, conserva, investiga, difunde e expõe os testemunhos materiais do homem e de seu entorno, para educação e deleite da sociedade.

${ }_{179}^{179}$ Países de língua portuguesa no continente africano.

180 SUANO, Marlene. O que é Museu. Brasiliense.

${ }^{181}$ Apud REBOLLO, Com relação à exposição dos acervos de museus, Ulpiano Bezerra de Meneses observa: "Os museus, com seu acervo, oferecem a possibilidade de uma exploração não só cognitiva mas também afetiva. Dispõem de um referencial sensorial importantíssimo, constituem terreno fértil para a manipulação de identidades. Os objetos transformam-se em catalisadores e difusores de sentidos e aspirações". A exposição torna-se, segundo esse pesquisador, arena privilegiada para apresentar imagens de si e do outro. Tem o papel fundamental de legitimar o poder e o imaginário de uma determinada cultura (A Exposição Museológica:Pontos Críticos na Prática Corrente, "Ciências em Museu" [seminário], Belém, 1993). GONÇALVES, Rebollo, Lisbeth. Entre Cenografia, O museu e a Exposição de Arte no Século XX. Editora da Universidade de São Paulo/FAPESP, 2004 p.16. 
O Museu Nacional de Arte

Av. Ho Chi Min 1233

O Museu Nacional de Arte, MUSART, é o único museu de arte do País. Portanto, o maior centro de divulgação da produção artística moçambicana, fator este que consolidou na sua abertura em 18 de maio de 1989, tendo tido o seu Estatuto Orgânico aprovado pelo decreto no 20/96, de 11 de junho. O edifício pertencia originariamente à Associação Indo-Portuguesa, antigo Instituto Goano.

Como nos informa o folder institucional,

O MUSART é uma instituição pública, sem fins lucrativos, de caráter cultural e cientifico, ao serviço da sociedade e do seu desenvolvimento, que adquire, registra, documenta, conserva, pesquisa, expõe e divulga, com finalidade de estudo, educação e deleite, colecções e obras de arte, relativas a várias manifestações das artes visuais.

Processo encadeado por um grupo de intelectuais e artistas, esta iniciativa surge da necessidade e do reconhecimento de que a maior parte da produção artística moçambicana ou estava nas mãos dos artistas ou estava fora do País, caracterizando a evasão e a alienação da cultura nacional. Hoje seu acervo consta de duas mil peças, tendo 107 obras distribuídas em duas salas, em exposição permanente.

Localizado na Av Ho Chi Min, uma das principais artérias da cidade, o Museu Nacional de Arte vem aumentando gradativamente as suas coleções através de doações dos próprios artistas e também de empresas.

A estrutura física do MUSART conta com salas para reserva técnica, serviços de conservação e restauro, uma biblioteca, uma sala e dois espaços para as exposições temporárias. Além de contar com um serviço educativo que realiza programas regulares com crianças, palestras e exposições de artistas nacionais e estrangeiros, e outros eventos. Sedia desde 2004 a Bienal organizada pelo Movimento de Arte Contemporânea de Moçambique, MUVART. 


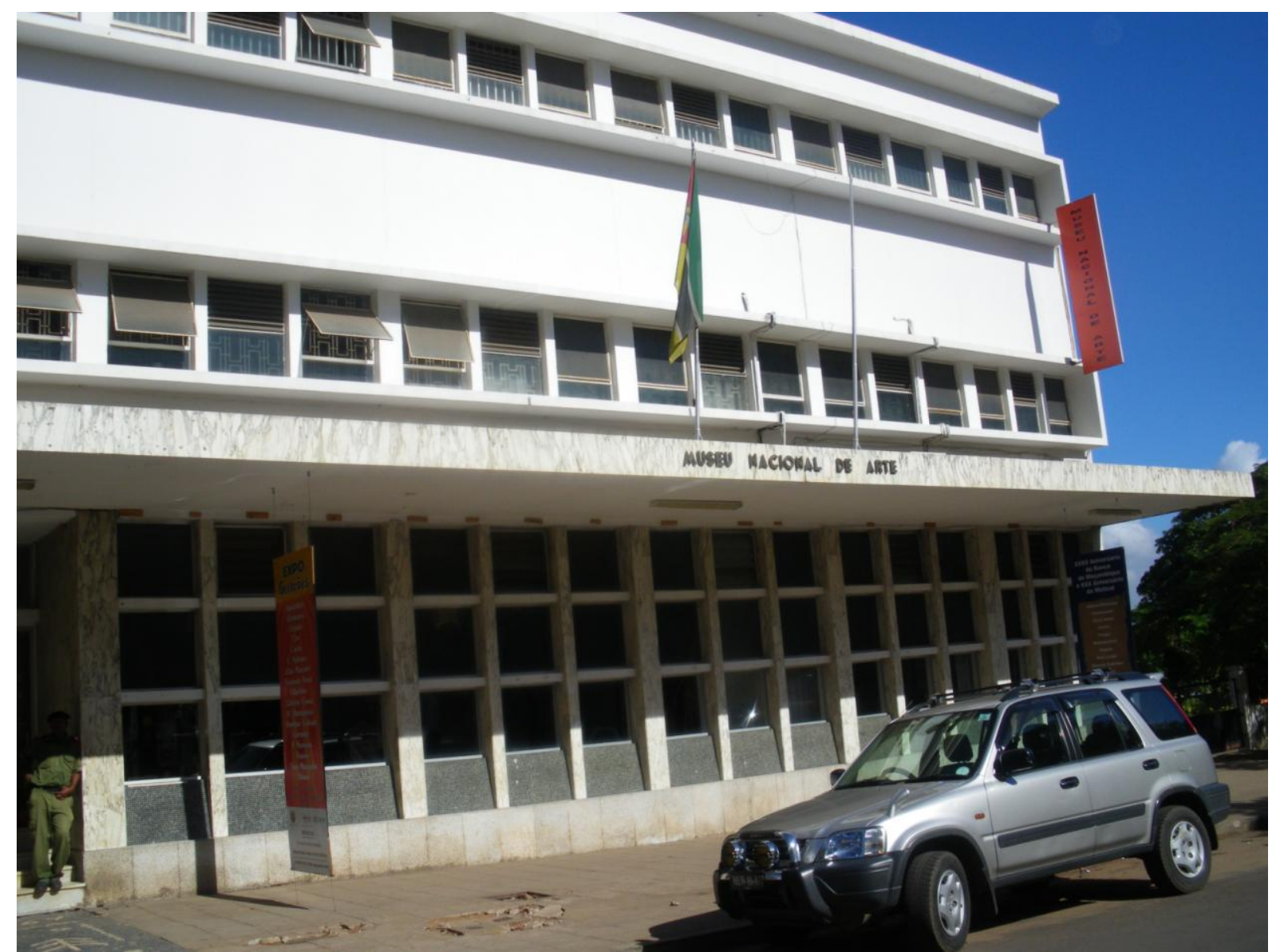

Museu Nacional de Arte (vista da fachada).

Maputo, Moçambique, jul.2010.

Foto Isa Bandeira

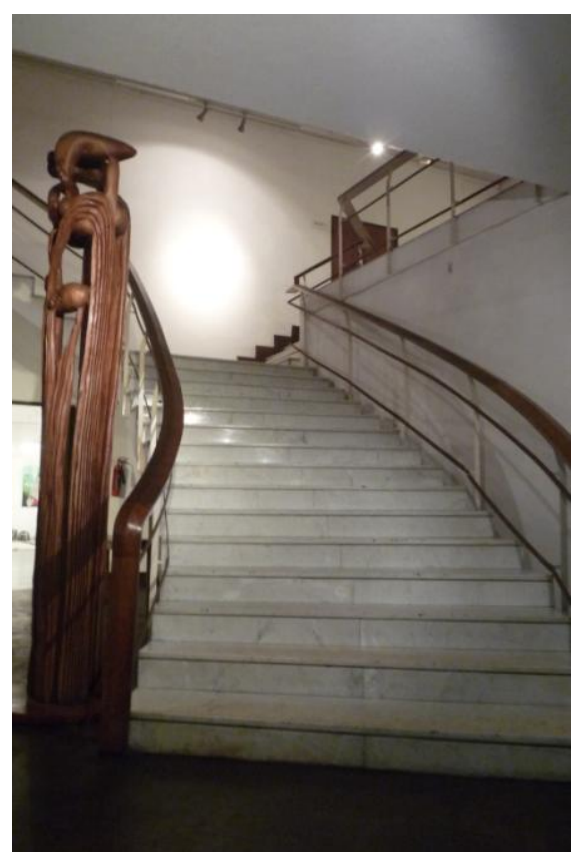

Museu Nacional de Arte (detalhe). Maputo, Moçambique, ago.2010 Foto Vera de Albuquerque

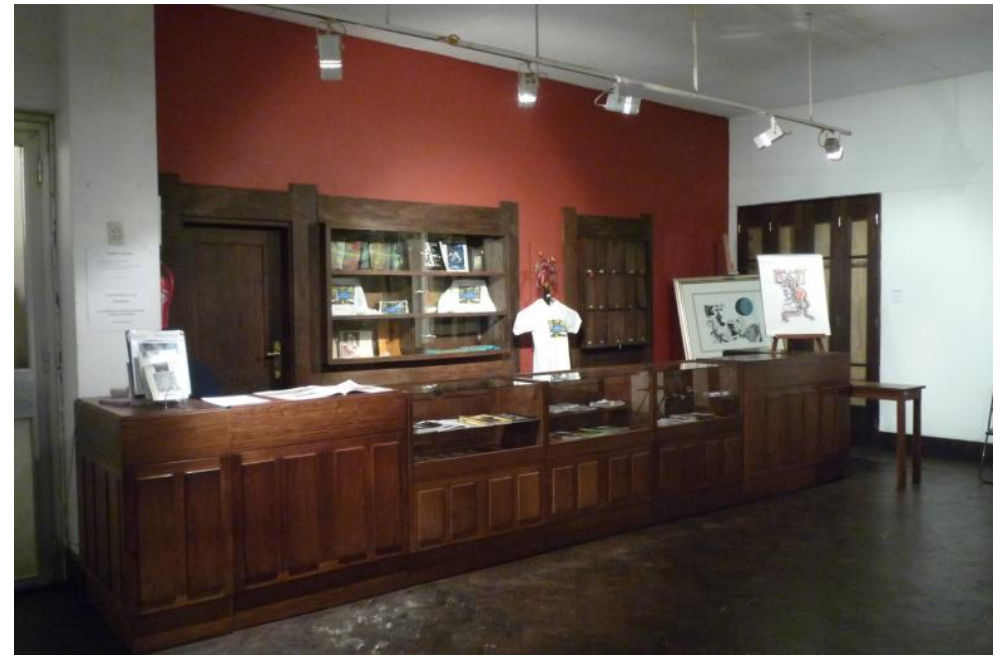

Museu Nacional de Arte (detalhe). Maputo, Moçambique, ago.2010. Foto Vera de Albuquerque 
Centro Cultural Brasil-Moçambique

Av. Karl Marx 1728

Centros Culturais Brasileiros: ${ }^{182}$

O Centro Cultural Brasil-Moçambique é um espaço de divulgação da cultura brasileira no exterior, com sedes também em outros países além do continente africano, e de apoio às iniciativas culturais locais, onde se encontra sediado. A partir da década de 1950, os centros culturais são realidade em diversas partes do globo.

Para melhor exemplificar o papel dos centros culturais, extraímos do site do Ministério das Relações Exteriores o seguinte texto sobre a missão desta Instituição:

Os Centros Culturais Brasileiros são instituições diretamente subordinadas
ao Chefe da Missão Diplomática ou repartição consular do Brasil em cada
país, constituindo o principal instrumento de execução da nossa política
cultural no exterior. Suas atividades estão relacionadas ao ensino
sistemático da Língua Portuguesa falada no Brasil; à difusão da Literatura
Brasileira; à distribuição de material informativo sobre o Brasil; à
organização de exposições de artes visuais e espetáculos teatrais; à co-
edição e distribuição de textos de autores nacionais; à difusão de nossa
música erudita e popular; à divulgação da cinematografia brasileira; além de
outras formas de expressão Cultural Brasileira, como palestras, seminários
e outros.
... "Ao longo de cinco décadas, entre os diretores dos CCBs sobressaem os
nomes de Maria Julieta Drummond de Andrade (CCB Buenos Aires, 1976-
83), Ipojuca Pontes (CCB Buenos Aires, 1991-92) e Fernanda Veríssimo
(CCB Maputo, 1998-1999), bem como o nome do artista plástico brasileiro
Lívio Abramo à frente do Setor de Artes do CEB Assunção (1962-92).

Os países onde existe a representação dos Centros Culturais Brasileiros (CCBs) estão assim distribuídos: no continente americano: Assunção (Paraguai); Georgetown (Guiana); Paramaribo (Suriname); La Paz (Bolívia); Lima (Peru); Manágua (Nicarágua); México (México); Panamá (República do Panamá); Santiago (Chile); São Domingos (República Dominicana); São Salvador (El Salvador); Porto Príncipe (Haiti); no continente europeu: Barcelona (Espanha); Roma (Itália); Helsinque (Finlândia) e, no nosso caso específico, no continente africano, com seis representações, Bissau (Guiné Bissau); Luanda (Angola); Maputo (Moçambique);

\footnotetext{
182 http://www.dc.mre.gov.br/lingua-e-literatura/centros-culturais-do-brasil, Acessado em: 5 de novembro de 2010.
} 
Pretória (África do Sul); São Tomé (São Tomé e Príncipe) e Praia (República do Cabo Verde).

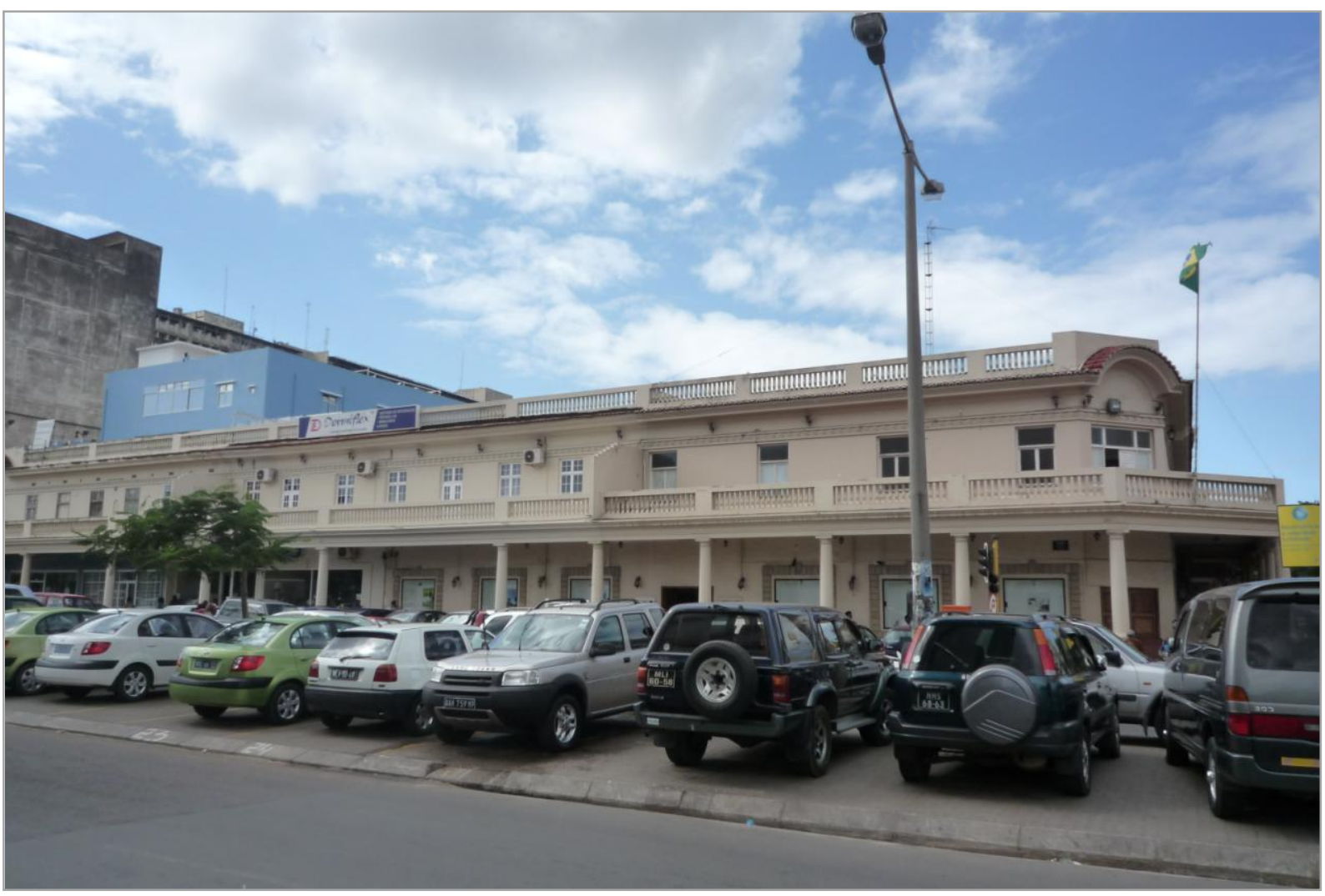

Centro Cultural Brasil-Moçambique (vista da fachada) Maputo, Moçambique, ago.2010.

Foto Vera de Albuquerque

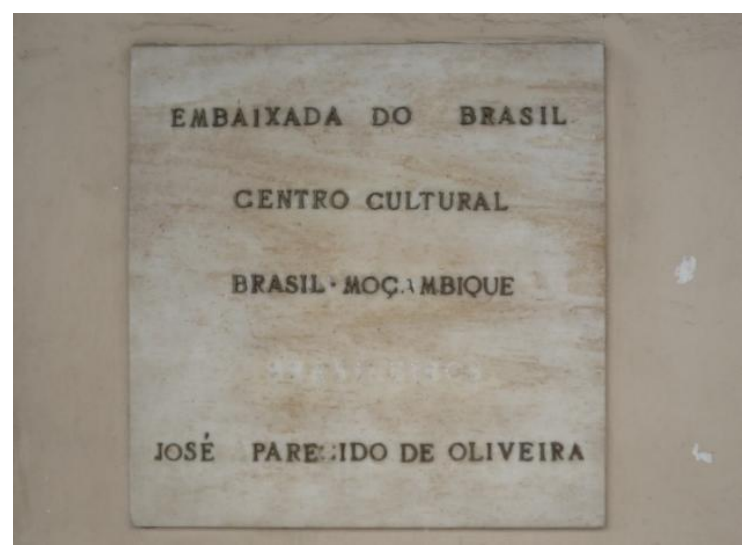

Placa na entrada

Centro Cultural Brasil-Moçambique

Maputo, Moçambique, ago.2010.

Foto Vera de Albuquerque

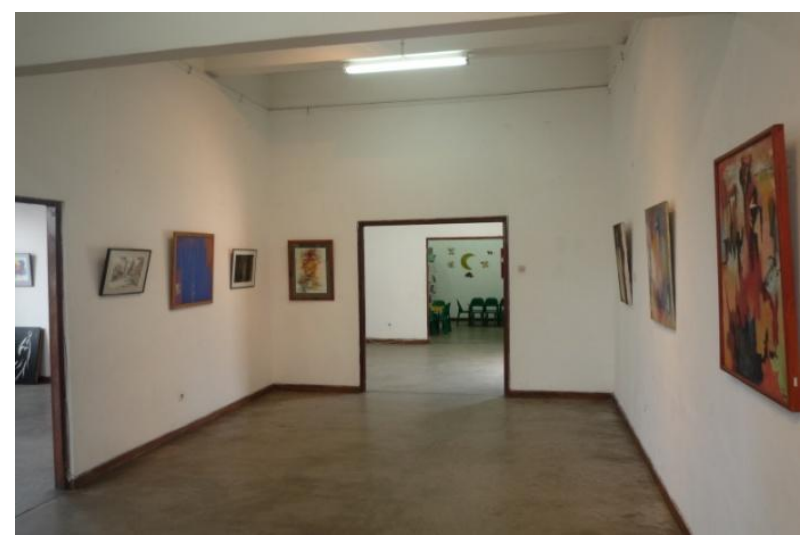

Acesso principal

Centro Cultural Brasil-Moçambique

Maputo, Moçambique, ago.2010

Foto Vera de Albuquerque 
Estação Central dos Caminhos de Ferro - CFM

Sala de Espera - Associação Kulungwana para o Desenvolvimento Cultural

Av. Eduardo Mondlane

A Associação Kulungwana para o Desenvolvimento Cultural é uma organização moçambicana dedicada a divulgar a diversidade de sua cultura. Foi constituída em 23 de maio de 2006. A organização tem uma galeria na Estação Central dos Caminhos de Ferro, CFM, em Maputo, desde 18 de abril de 2008, onde abriga exposições de pintura, escultura, cerâmica e fotografia durante o ano inteiro, no espaço denominado Sala de Espera.

A Estação Central dos Caminhos de Ferro, CFM, cuja construção foi começada no ano de 1908, foi inaugurada somente em 19 de março de 1910, obra do século XX, tendo como autor de seu projeto o engenheiro Lisboa de Lima.

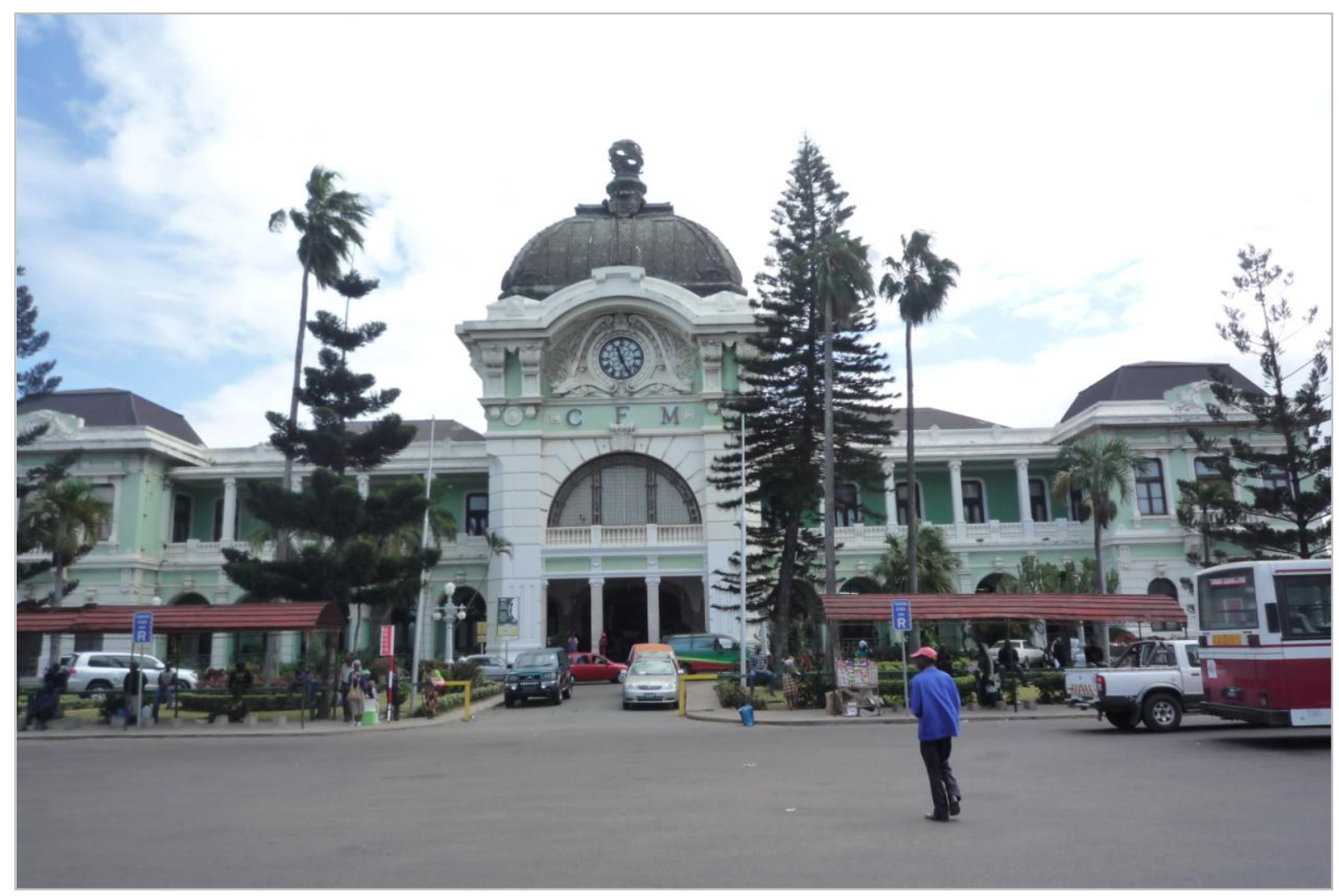

Estação Central dos Caminhos de Ferro (vista da fachada) Maputo, Moçambique. ago.2010.

Foto Vera de Albuquerque 


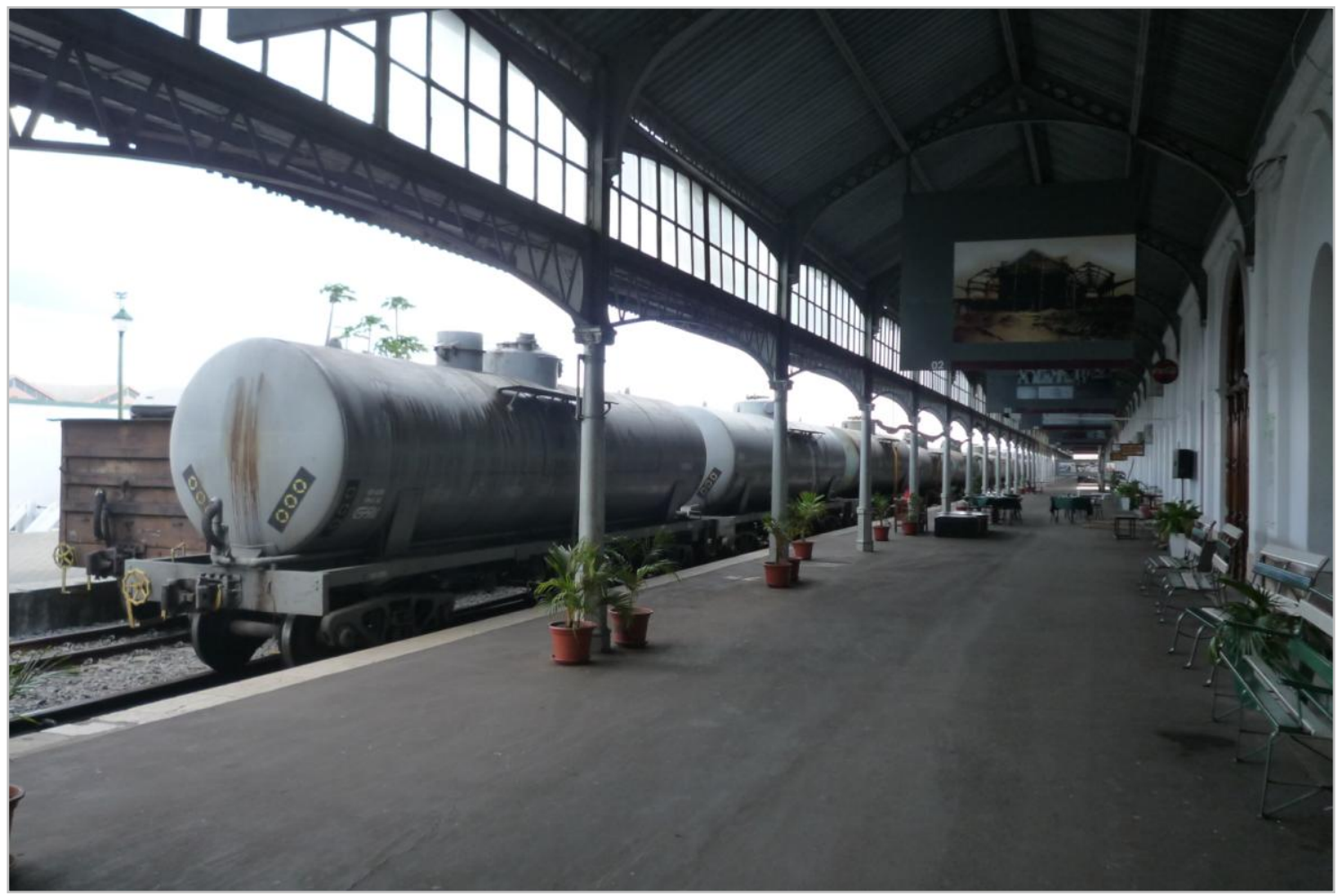

Estação Central dos Caminhos de Ferro (parte interna) Maputo, Moçambique, ago.2010. Foto Vera de Albuquerque

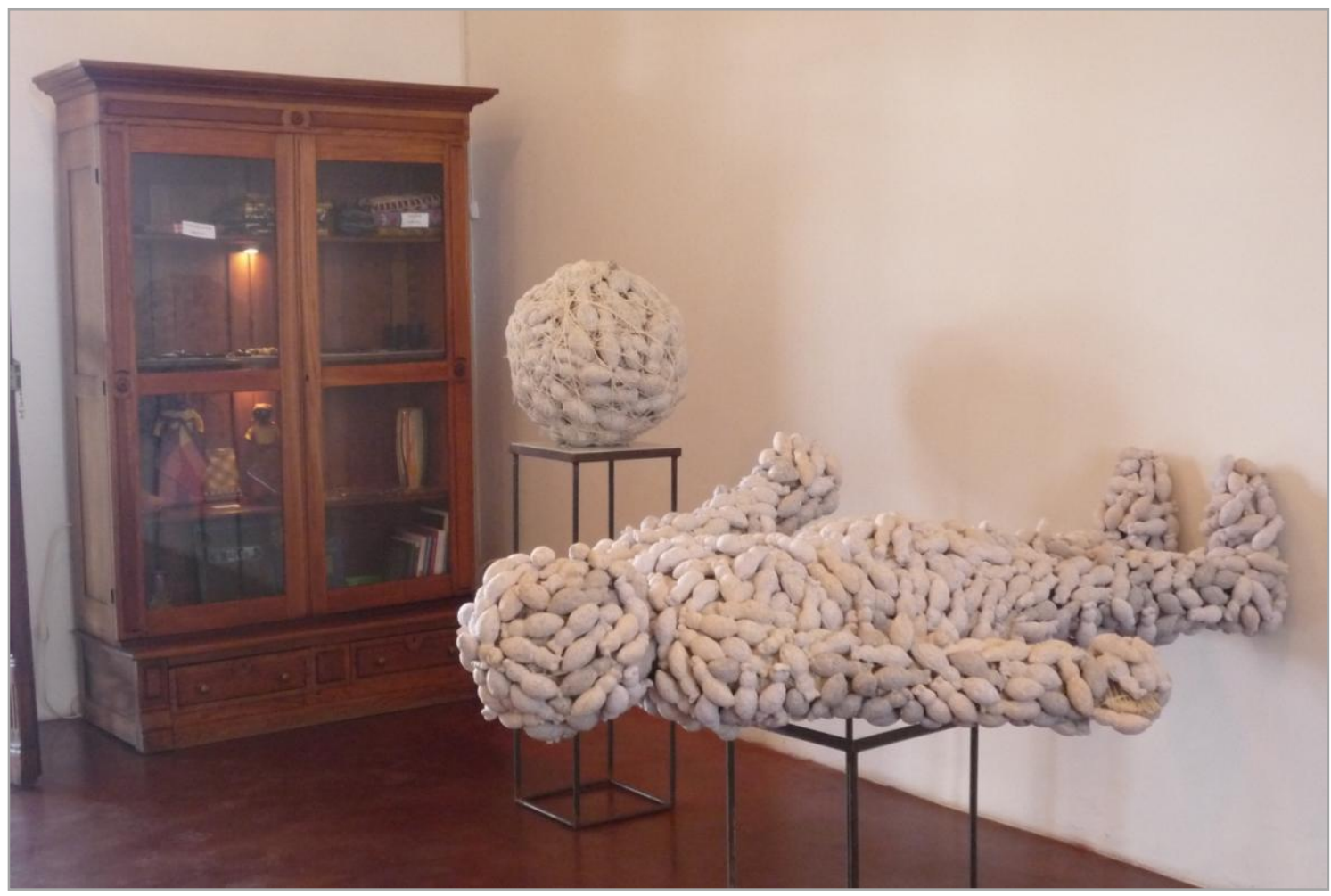

Estação Central dos Caminhos de Ferro (sala de exposição, detalhe da obra de Jorge Dias) Maputo, Moçambique. ago.2010.

Foto Vera de Albuquerque 
Instituto Camões - Centro Cultural Português em Maputo

Av. Julius Nherere 720

O Instituto Camões inaugurou o seu Centro Cultural Português em 1996 e está instalado no Edifício da Embaixada de Portugal. É estruturalmente dividido em três secções, a saber; Biblioteca e Centro de Recursos, Animação Cultural e Galeria, e Direção e Serviços Administrativos.

No âmbito deste estudo o setor de Animação Cultural e Galeria compreende exposições de artistas plásticos locais e portugueses, palestras, mesas redondas, entre outras atividades relacionadas à promoção artística.

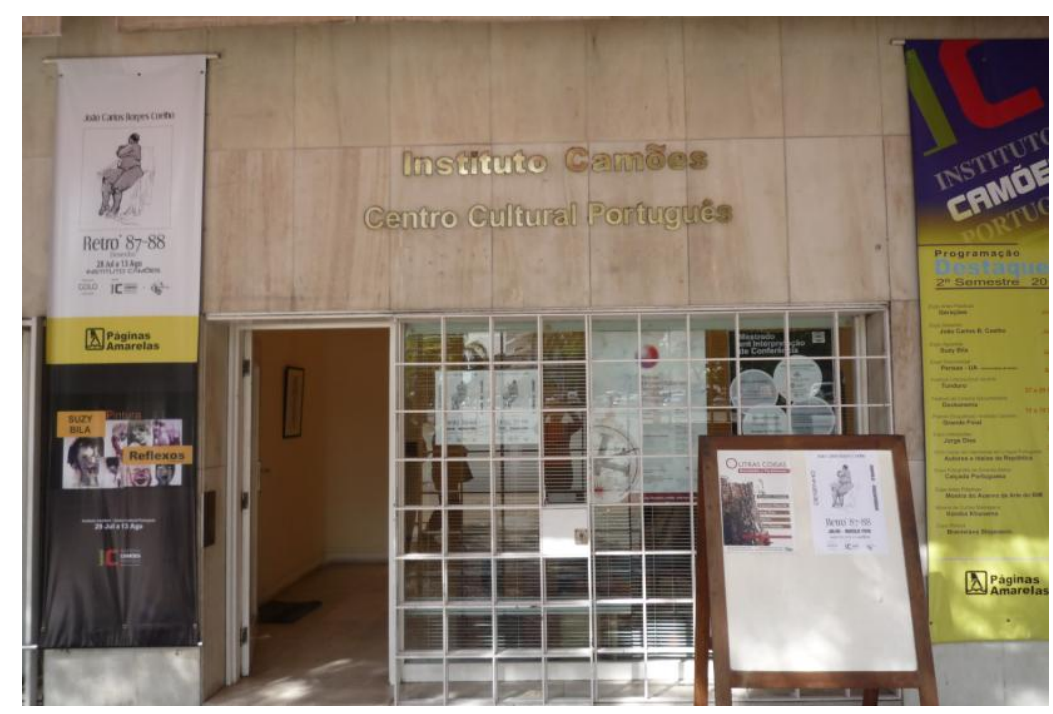

Centro Cultural Português em Maputo (acesso principal) Maputo, Moçambique. ago.2010.

Foto Vera de Albuquerque

Galeria do Centro Cultural Português em Maputo. Maputo, Moçambique. Ago. 2010.

Foto Vera de Albuquerque

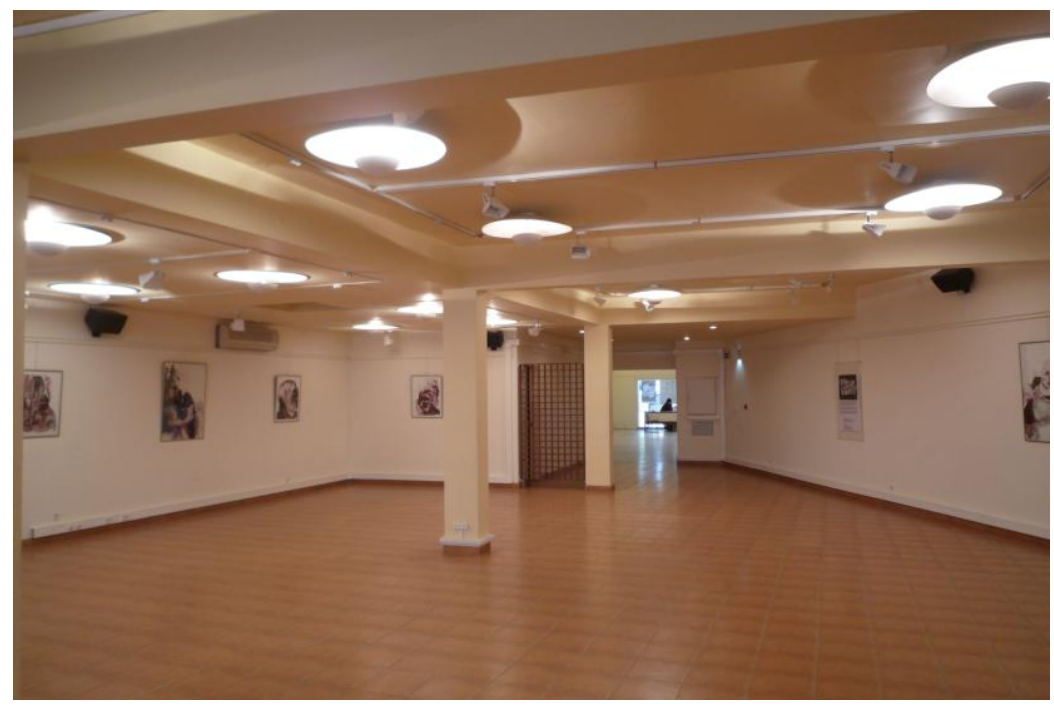


Centro Cultural Franco Moçambicano - CCFM

Av. Samora Machel 468

O Centro Cultural Franco-Moçambicano foi inaugurado no dia 13 de julho de 1995. Estiveram presentes no ato solene o Primeiro-Ministro de Moçambique, Pascal Mocumbi, e o embaixador da França em Moçambique, Didier Destremeau.

Sua gestão é binacional, ou seja, o conselho administrativo é presidido alternadamente pelo Ministro da Educação e Cultura de Moçambique e pelo Embaixador da França.

Passando por dois períodos históricos anteriores, o edifício inicia sua trajetória como um Hotel Clube, por volta de 1887, como um cassino; posteriormente, em 1896, como um hotel para atender aos mineiros vindos da África do Sul, e atualmente como o conhecemos, como o Centro Cultural FrancoMoçambicano, após uma temporada de dois anos de reforma de suas instalações.

A missão do Centro Cultural Franco-Moçambicano é atender às iniciativas advindas, principalmente, da África francófona e estimular a produção local. Suas instalações modernas contam com duas salas de espetáculos, salas de exposições, biblioteca, salas de aulas, restaurante e loja de souvenirs. O edifício está situado no centro da baixa, bairro histórico da cidade.

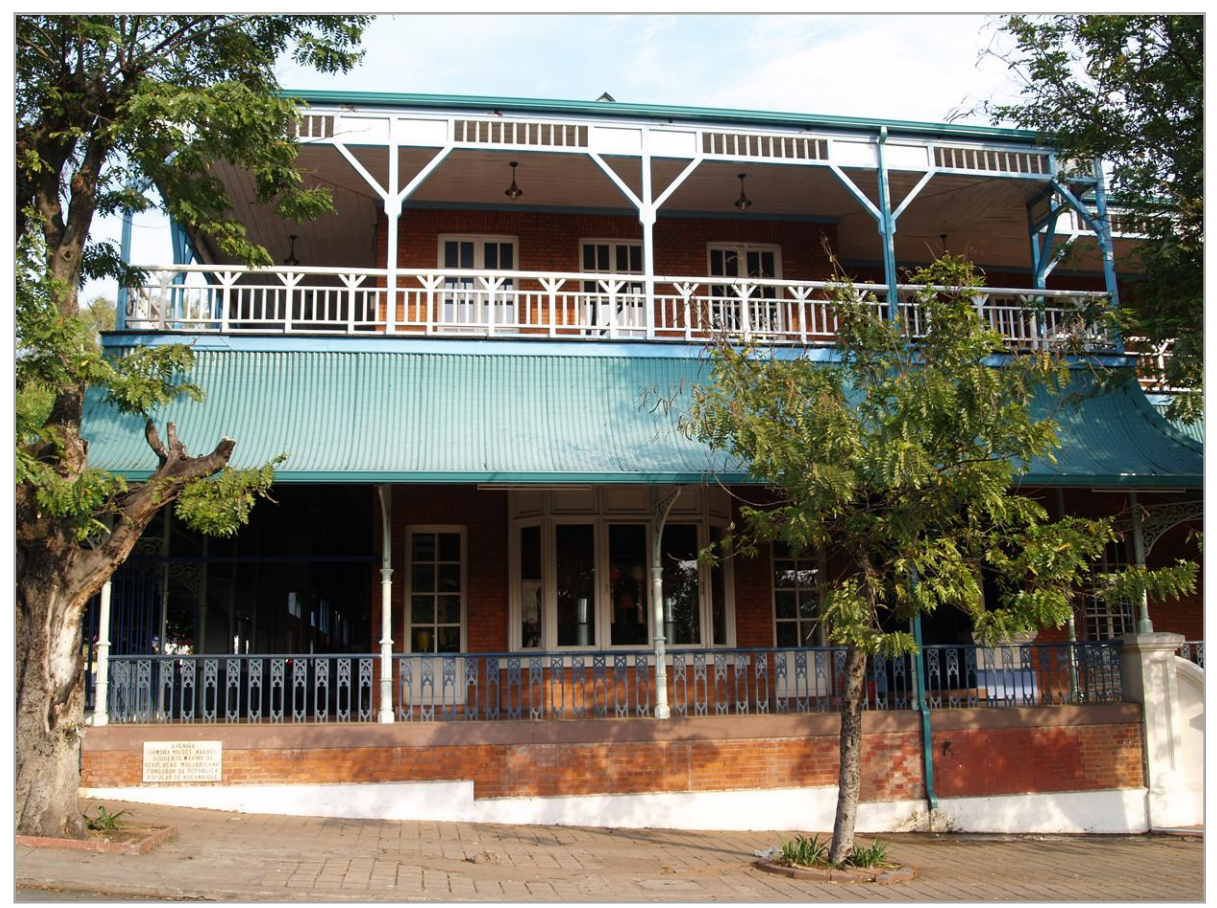

Centro Cultural

Franco-Moçambicano (fachada)

Maputo,

Moçambique.

nov.2010.

Foto Maimuna Adam 


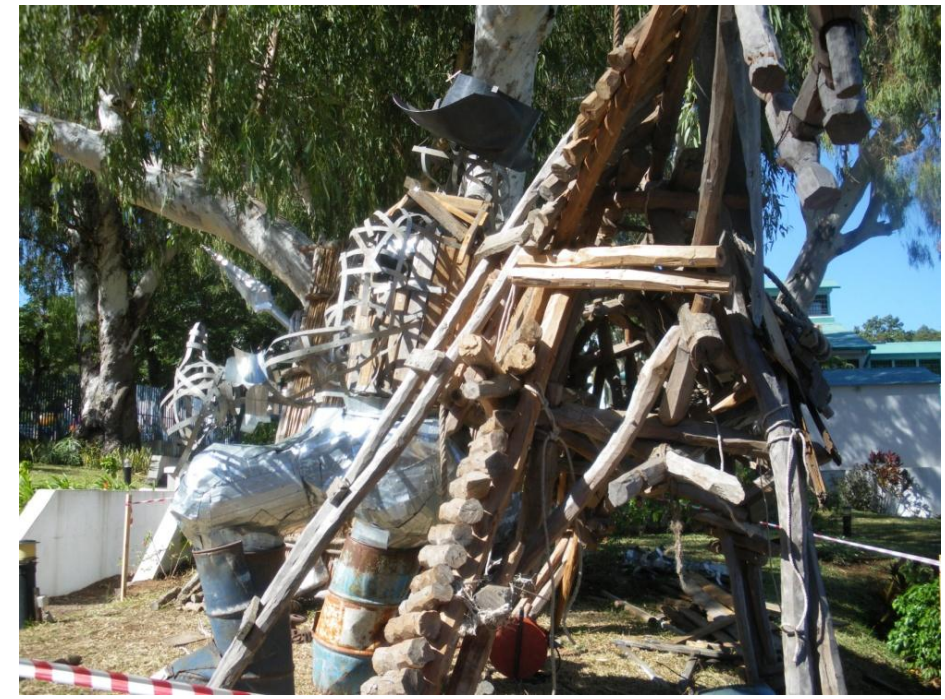

Centro Cultural Franco-Moçambicano (área interna)

Maputo, Moçambique. nov.2010.

Foto Maimuna Adam

Centro Cultural Franco-Moçambicano

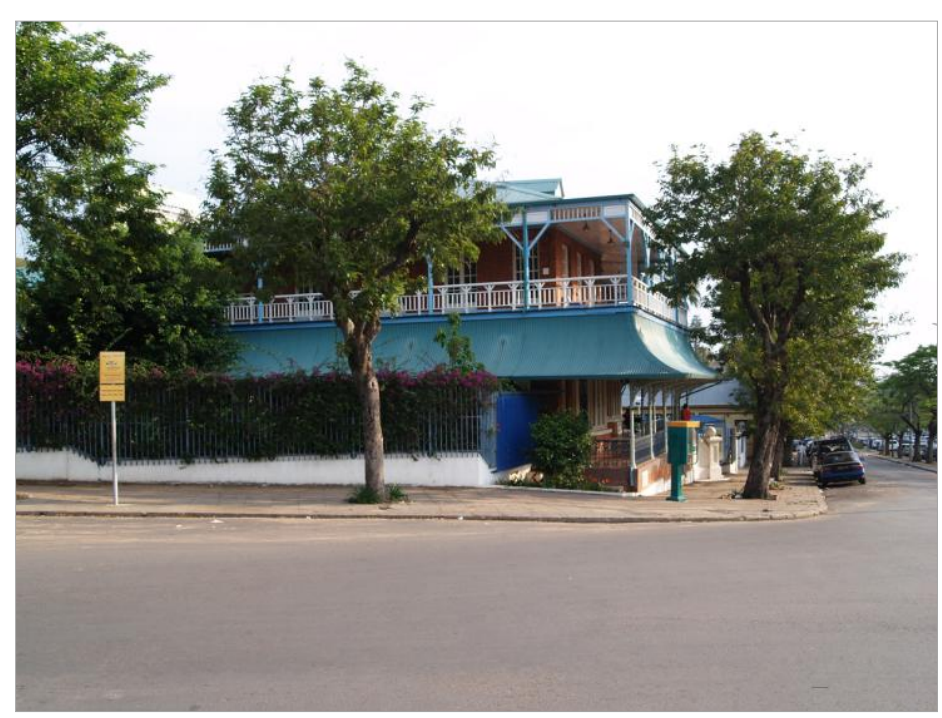
(fachada)

Maputo, Moçambique.

nov.2010.

Foto Maimuna Adam

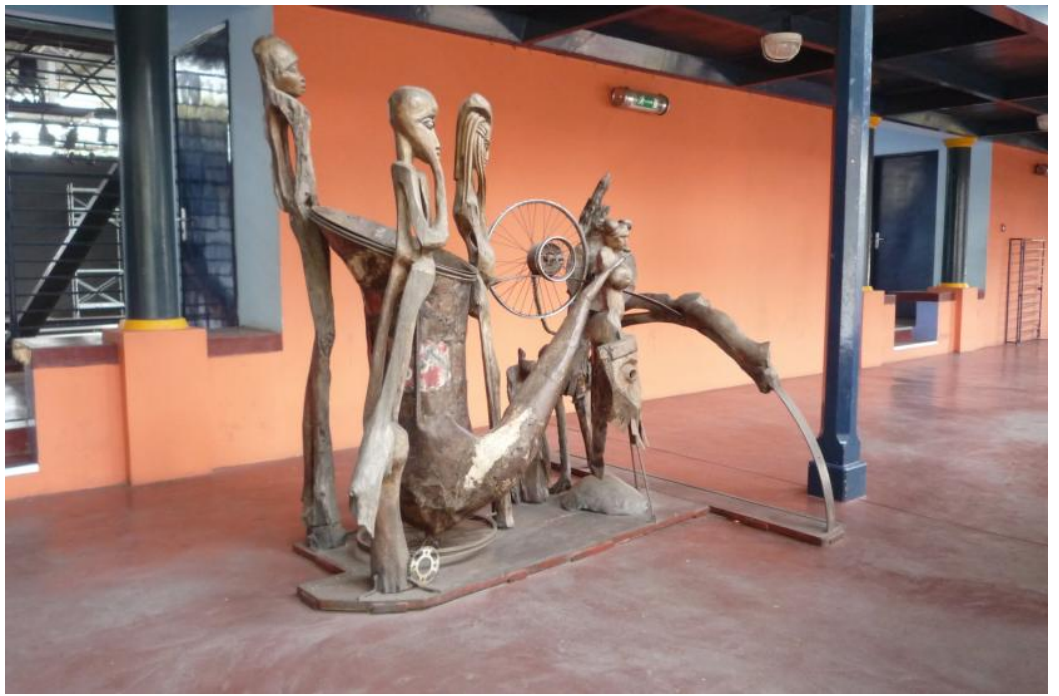

Centro Franco-Moçambicano.

(área interna)

Maputo, Moçambique.

ago.2010.

Foto Vera de Albuquerque 
Galeria de Arte da Casa de Cultura do Alto Maé

Esquina das Avenidas Albert Lithuli/Ho Chi Min 1719

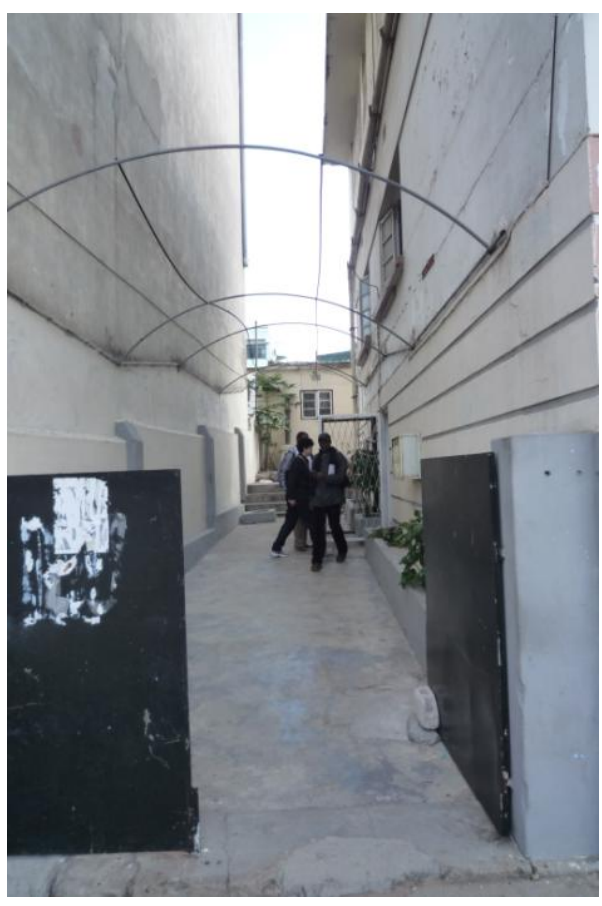

Galeria Alto Maé (entrada). Maputo, Moçambique, ago.2010. Foto Vera de Albuquerque

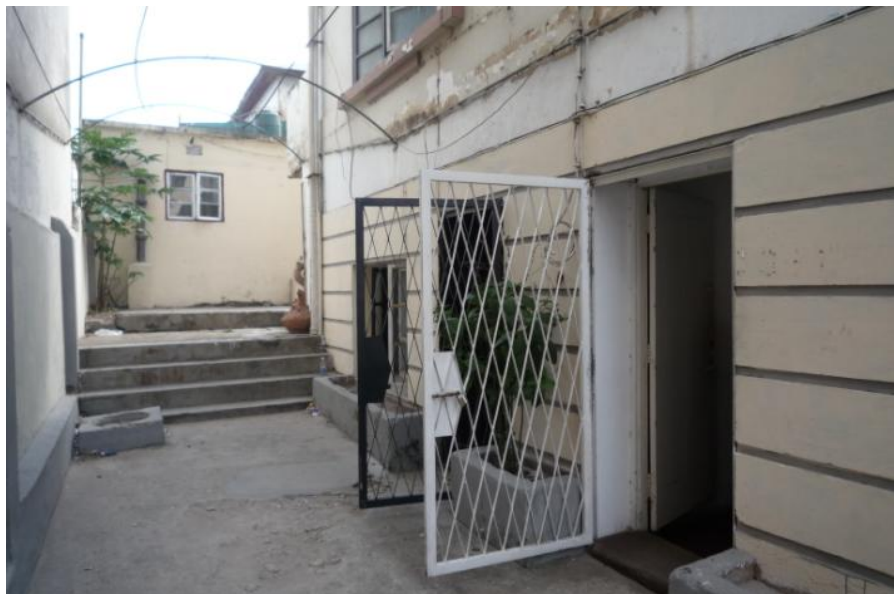

Galeria Alto Maé (entrada) Maputo, Moçambique, ago.2010.

Foto Vera de Albuquerque

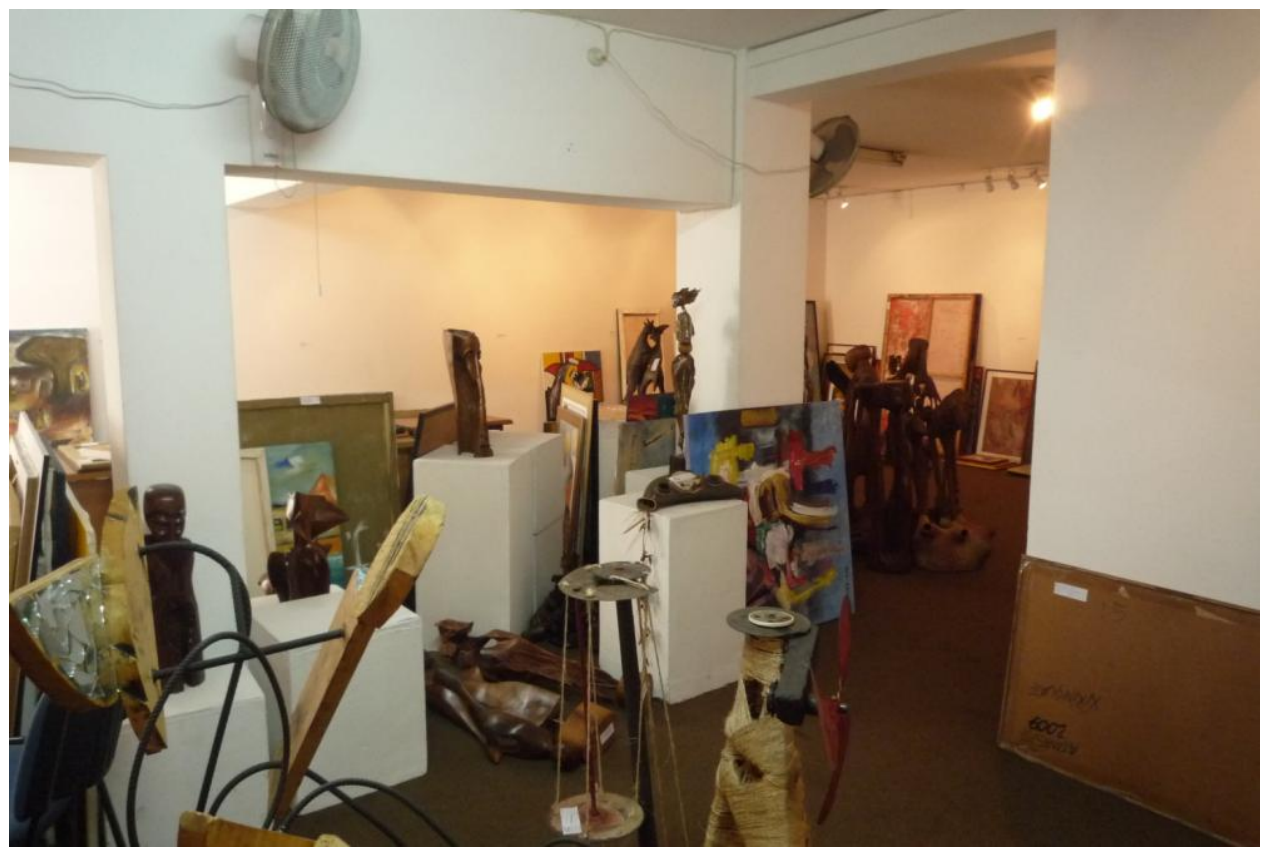

Galeria Alto Maé (sala de exposição em montagem) Maputo, Moçambique. ago.2010. Foto Vera de Albuquerque 
Centro de Formação Fotográfica - CFF

Atualmente Centro de Documentação e Formação Fotográfica- CDFF

Av. Josina Machel, 1071

O Centro de Formação Fotográfica, CFF, iniciou suas atividades em 1984, como Escola de Fotografia, com apoio da Cooperação Italiana. Ricardo Rangel, após carreira como fotojornalista, cria juntamente com outros o Centro de Formação Fotográfica, $\mathrm{CFF}^{183}$, onde trabalha até a data de seu falecimento em 11 de junho de 2009. ${ }^{184}$ Personagem de referência no fotojornalismo e influenciador das novas gerações, tem suas fotografias expostas em várias partes do mundo. Encontra-se no site do CDFF a sua história:

\begin{abstract}
Mesmo com parcos recursos, os fotógrafos do CFF começaram a recolher imagens sobre assuntos sócio-culturais, econômicos e históricos, de Norte ao Sul, para contribuir para a diginificação e divulgação da riqueza históricocultural e paisagística de Moçambique. Este esforço e trabalho sistemático valeu ao centro, em 1988, o reconhecimento oficial e a aquisição do estatuto de Arquivo Nacional de Fotografia, constituindo-se, assim, como Centro de Documentação e Formação Fotográfica. Actualmente, o CDFF apresenta-se como o único arquivo de fotografia do país, onde varias instituições do governo, ong's, agencias de desenvolvimento tem recorrido para melhorar os seus instrumentos de trabalho.
\end{abstract}

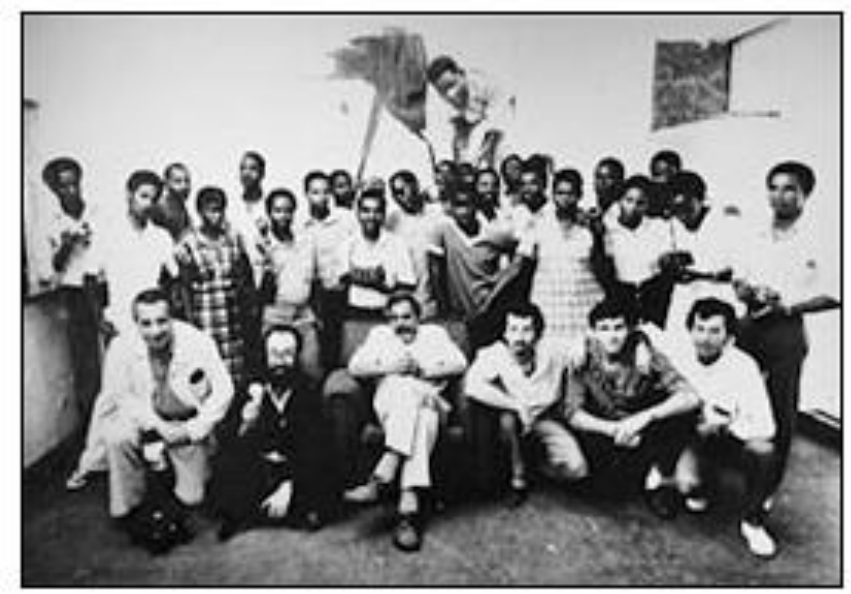

Centro de Formação Fotográfica.

Maputo, Moçambique.

Fonte http://cdff.virb.com/historia

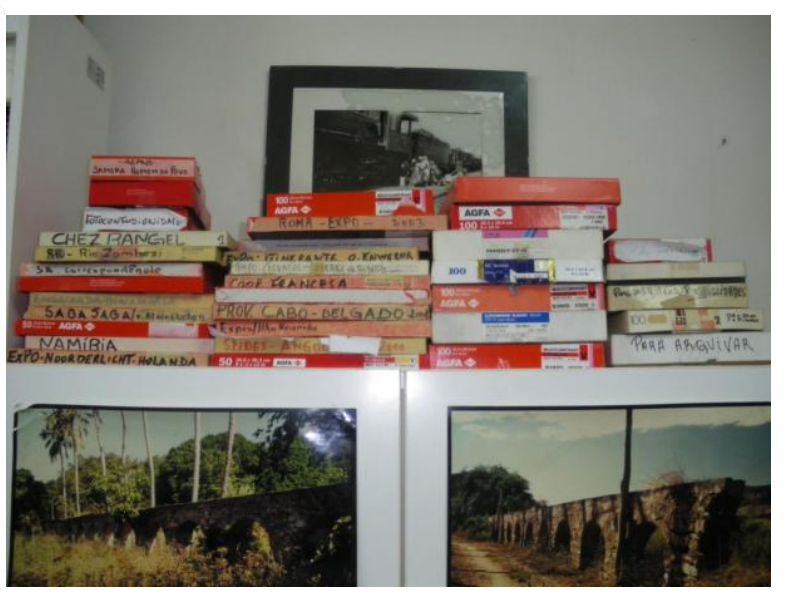

Centro de Formação Fotográfica Maputo, Moçambique, jul.2010 Foto Maimuna Adam

\footnotetext{
183 No site do CDFF são citados outros colaboradores, porém não são nomeados.

184 Fotógrafo de origem euro-afro-asiática nascido em Lourenço Marques, hoje Maputo, em 15 de fevereiro de 1924.
} 
Associação Moçambicana de Fotografia - AMF

Av. Julius Nyerere, 618

Fundada em 1981, também funciona como um polo cultural, dentro da sociedade moçambicana, recebendo exposições.

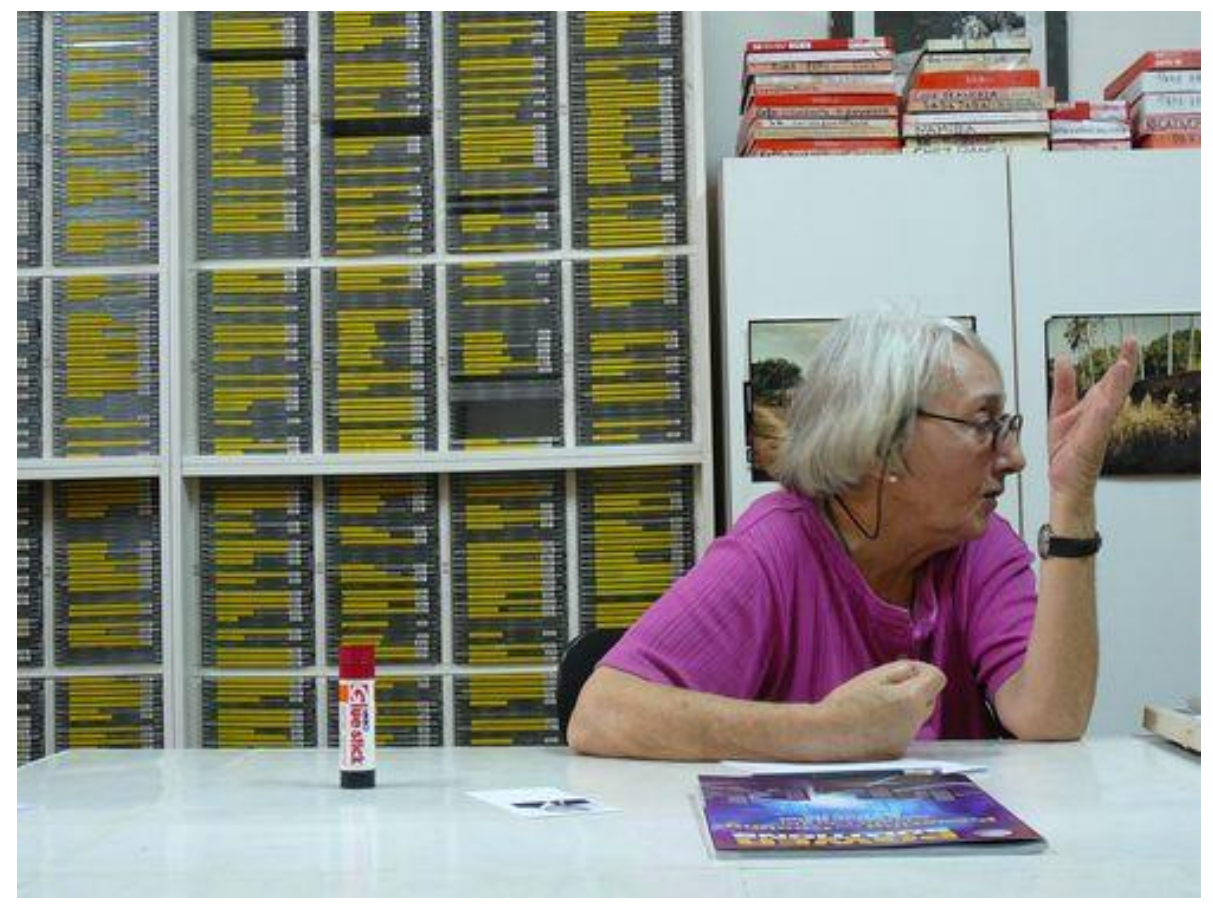

Beatrice Kiener e os arquivos do CDFF, em setembro 2007 (Foto @ Luisa Cortesão) 
Núcleo de Arte

Rua da Argélia, 194

O Núcleo de Arte configura-se como uma entidade coletiva de caráter cultural sem fins lucrativos, dotada de personalidade jurídica e autonomia administrativa, financeira e patrimonial. Existe desde 1921, promove exposições, cursos, palestras e debates.

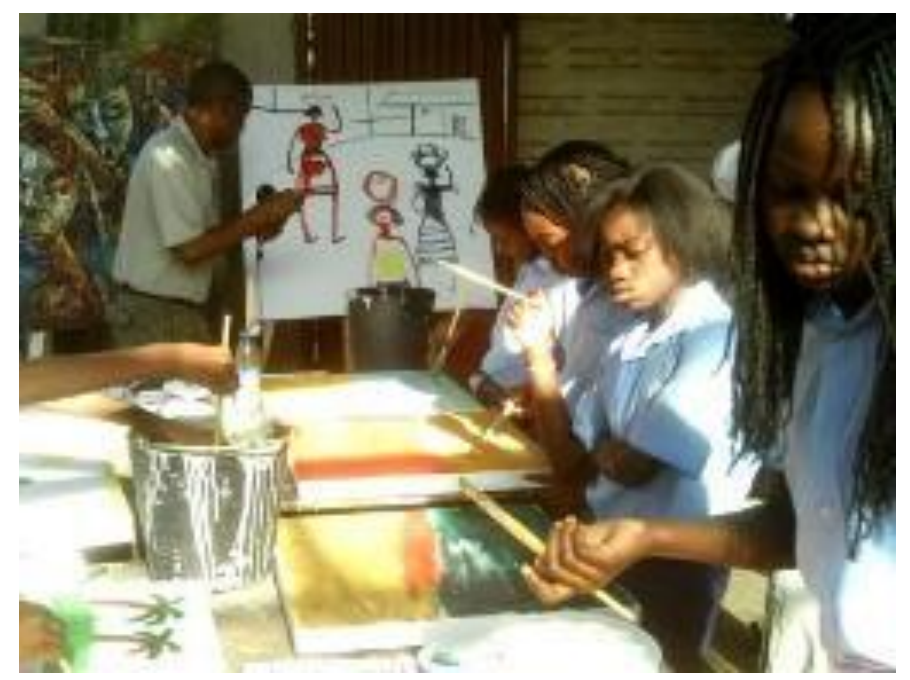

Núcleo de Arte, Maputo, Moçambique

Neto, com crianças "Mãozinha de talento"

Fonte: http://nucleodarte.com/Workshops.htm

Folder do evento promovido pelo Núcleo de Arte Fonte http://nucleodarte.com/Workshops.htm

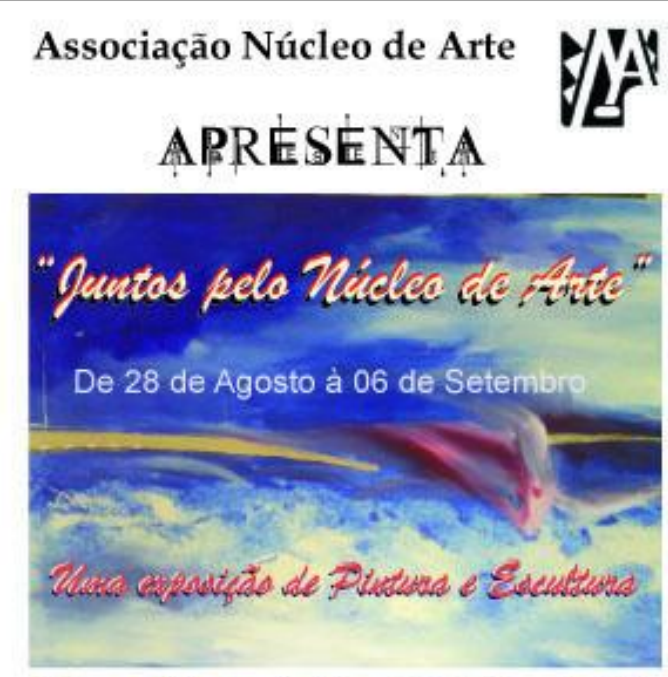

Artistas participantes: Noel langa, Estêvä̊ Mucavele, Victor Sousa, Norberto, Neto, Dito, Gumatsy, Fiel dos Santos, Forna, J. Queha, Makolwa, Saranga, Fornasini, Simpetane, Matxakossa, Pekiwa, Alexandria, Falcão, Matine, Chichongwe, Jamal, Itelio, Nhongwene, H.S. Nhackotou. Carmen, Lurdes Silva, Mila, Trindade, Matimele e Bento Mulungo.

As obras que estarăo expostas, săo resultado de um workshop, onde os artistas se unem para angariar fundos para reabilitaçăo das instalaçōes da associaçăo, entre outras observaçơes. 


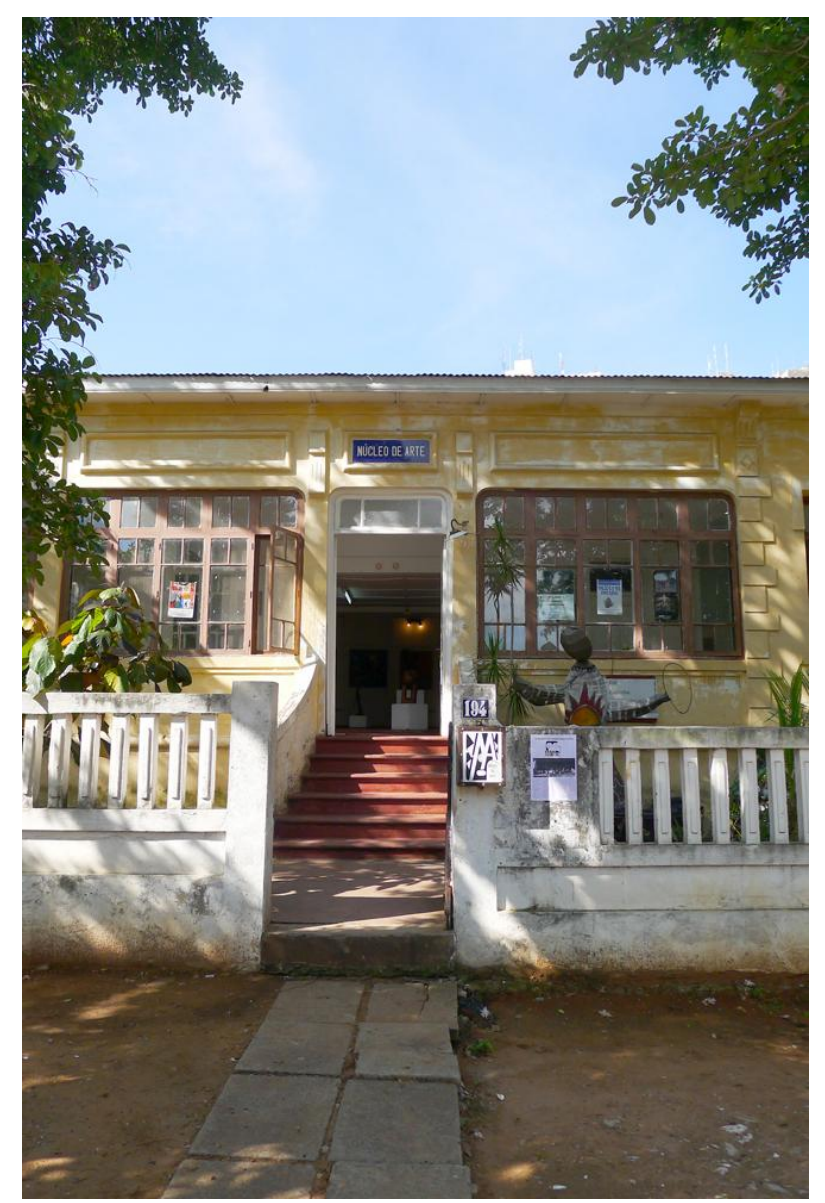

Núcleo de Arte (fachada)

Maputo, Moçambique.

dez.2010

Foto Maimuna Adam.

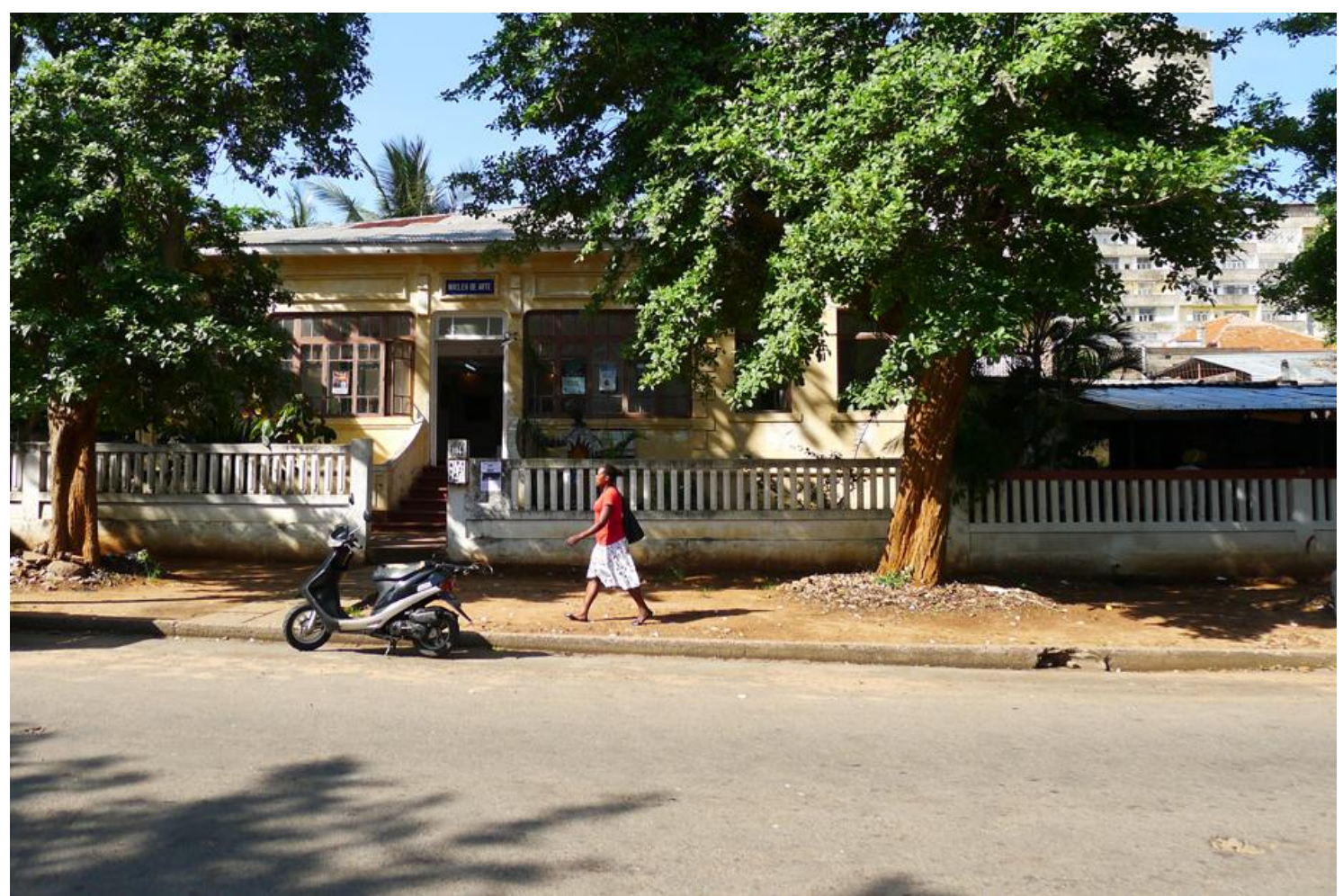

Núcleo de Arte (fachada)

Maputo, Moçambique.

dez.2010.

Foto Maimuna Adam 
Escola Nacional de Artes Visuais, ENAV.

Av. Fernão Magalhães, 83

Além das instituições de divulgação da produção artística de Maputo, as galerias, centros culturais e museus, iremos também incluir a Escola Nacional de Artes, ENAV, e o Instituto Superior de Arte, ISArC, como centros de formação na área de educação em artes. A maioria dos artistas pesquisados é formada de exalunos e atualmente alguns deles são professores.

A ENAV foi fundada em 1983, herdeira do Centro de Estudos Culturais, criado em 1977, sendo esta instituição oficial a única que ministra, em Moçambique, o ensino profissionalizante no campo das artes visuais, nos níveis básico e médio.

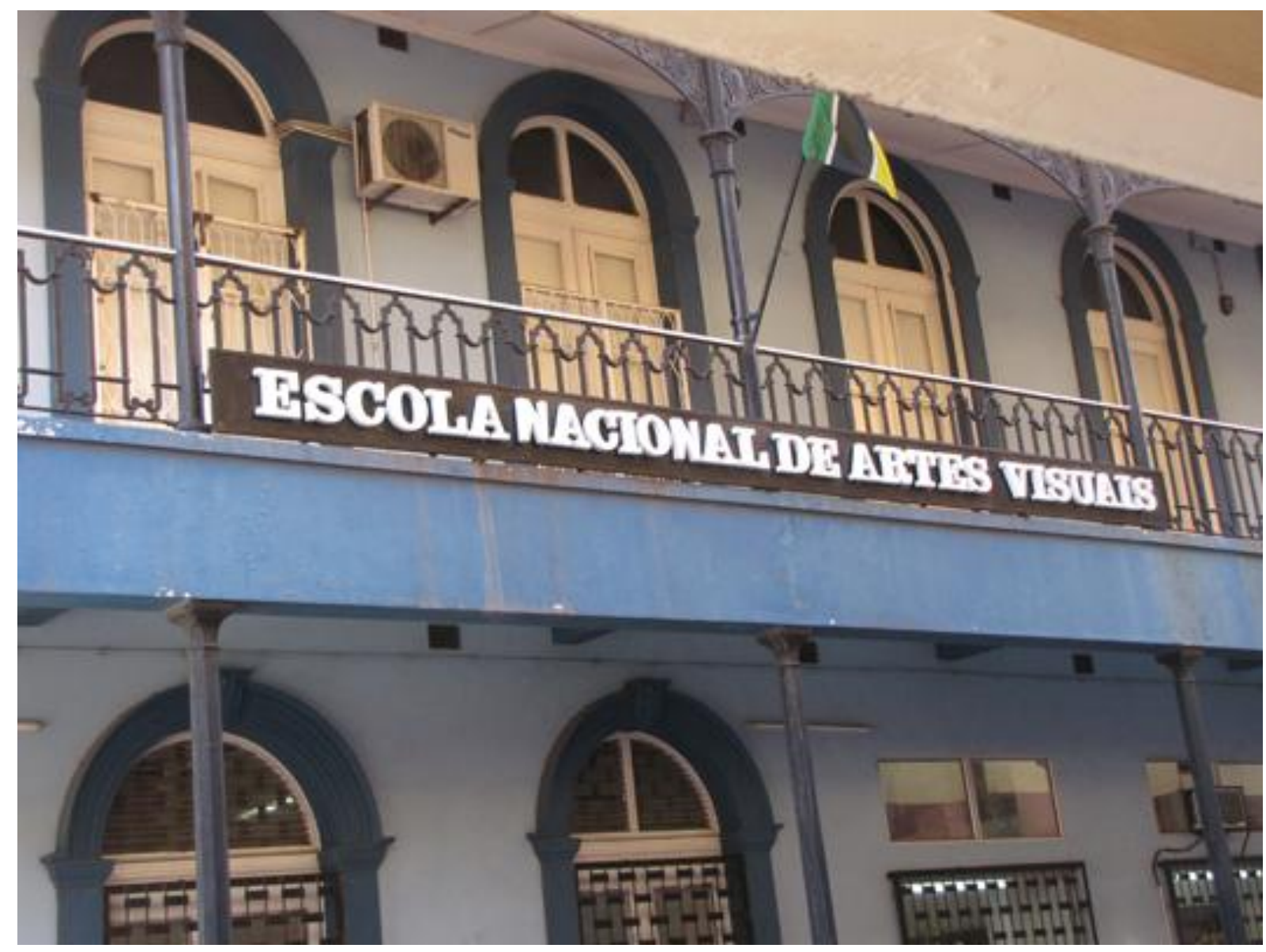

Escola Nacional de Artes Visuais (fachada) Fonte http://danaikipublications.org/artists.htm 
Instituto Superior de Artes e Cultura, ISArC.

Av. das Indústrias, 2671

Matola, Moçambique

Primeira instituição de nível superior dedicada à formação artística em Moçambique, localizada na Machava na cidade de Matola. No site do Instituto temse detalhada a sua missão:

Somos a primeira instituição de ensino superior na área das artes e cultura em Moçambique. A nossa sede está localizada na Machava, na cidade da Matola. O Instituto Superior de Artes e Cultura (ISArC) é uma pessoa colectiva de direito público, de âmbito nacional, dotada de personalidade jurídica, e goza de autonomia científica, pedagógica, administrativa e disciplinar.

Através do decreto número 45/2008 de 26 de Novembro, é criado o ISArC e no dia 15 de Setembro de 2009 iniciamos com as nossas actividades de ensino aprendizagem, comportando as seguintes faculdades:

- Faculdade de Artes onde ministramos os cursos de Artes Visuais e Design;

- Faculdade de Estudos da Cultura onde ministramos o curso de Animação Cultural;

Com um universo de cerca de 120 estudantes, começamos a funcionar, e, gradualmente, à medida que as condições forem sendo criadas, outros cursos poderão ser agregados.

No ISArC, alguns artistas fundadores do MUVART são professores, como Gemuce, Jorge Dias, Marcos Muthewuye, Maimuna Adam e a artista Carmen Muianga que dá prosseguimento como discente em sua formação.

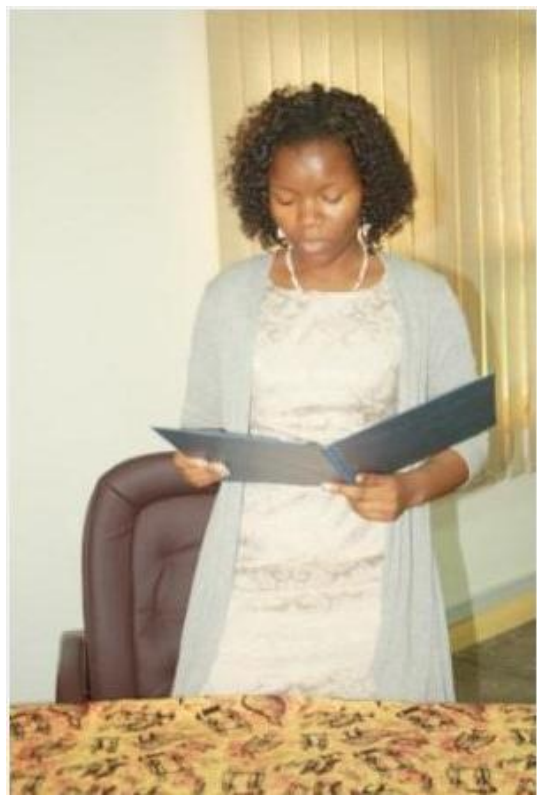

Cerimônia de tomada de posse dos diretores de faculdades do ISArC, 13 de maio de 2011, no ISArC

Fonte:

http://www.isarc.edu.mz/index.php?option=com content\&view=ar $\underline{\text { ticle\&id }=23 \& \text { Itemid }=28}$ 


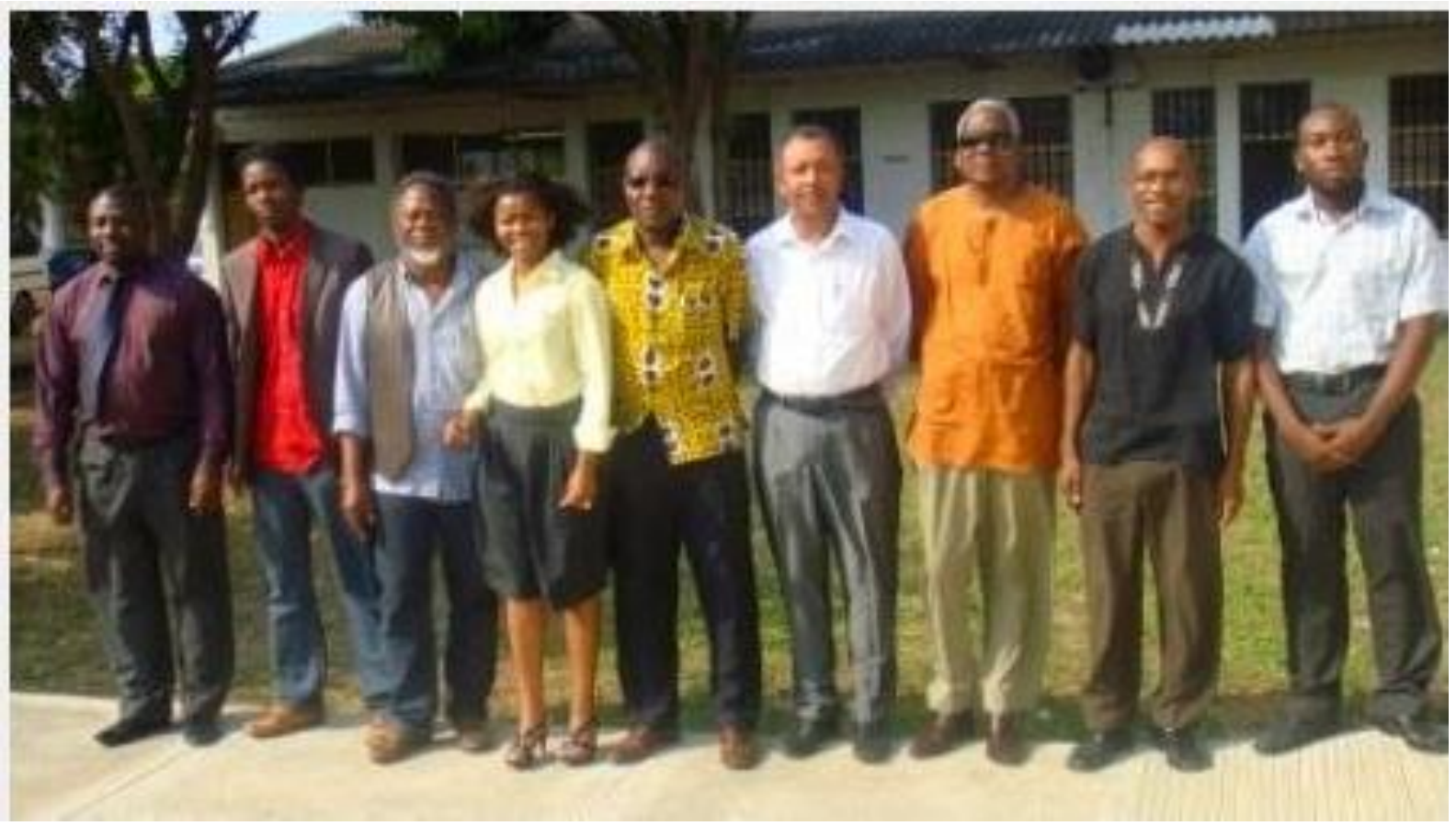

Cerimônia de tomada de posse dos Membros do Conselho Geral do ISArC, 06 de maio de 2011, no ISArC

Fonte http://www.isarc.edu.mz/index.php?option=com content\&view=article\&id=23\&ltemid=28 